\title{
HYDROLOGIC DATA \\ FOR THE POTOMAC FORMATION \\ IN NEW CASTLE COUNTY, DELAWARE
}

U.S. GEOLOGICAL SURVEY

WATER-RESOURCES INVESTIGATIONS

OPEN-FILE REPORT $\quad 81-916$

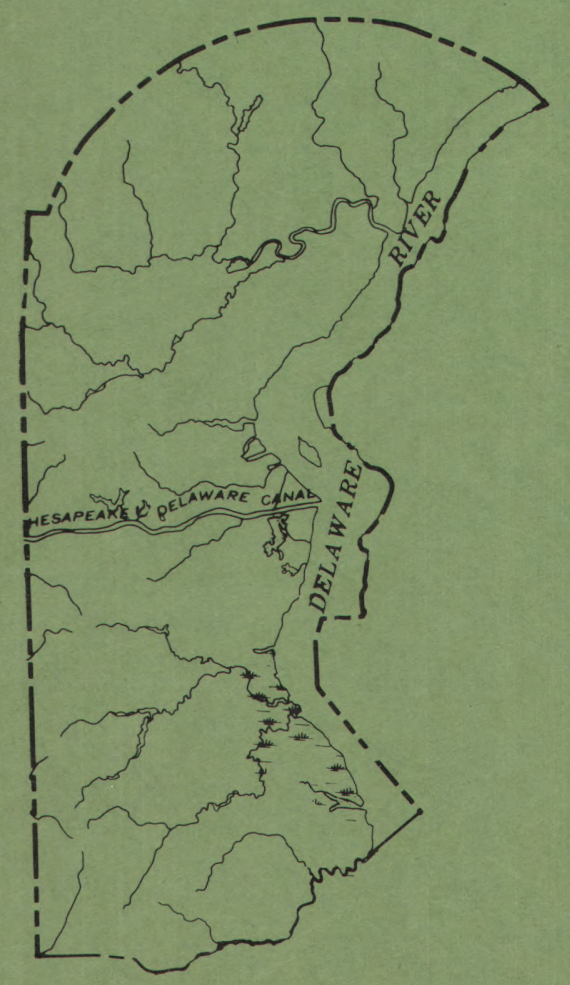

Prepared in cooperation with the

U.S. ARMY CORPS OF ENGINEERS

and the

DELAWARE DEPARTMENT OF NATURAL RESOURCES AND ENVIROMENTAL CONTROL 

UNITED STATES

DEPARTMENT OF THE INTERIOR

GEOLOGICAL SURVEY

HYDROLOGIC DATA FOR THE POTOMAC FORMATION

IN NEW CASTLE COUNTY, DELAWARE

By M. M. Martin and J. M. Denver

U.S. GEOLOGICAL SURVEY

WATER-RESOURCES INVESTIGATIONS

OPEN-FILE REPORT $\quad 81-916$

Prepared in cooperation with the

U.S. ARMY CORPS OF ENGINEERS

and the

DELAW ARE DEPARTMENT OF NATURAL RESOURCES

AND ENVIRONMENTAL CONTROL

Dover, Delaware 
UNITED STATES DEPARTMENT OF THE INTERIOR

JAMES G. WATT, Secretary

GEOLOGICAL SURVEY

Dallas L. Peck, Director

For additional information write to:

U.S. Geological Survey

Federal Building, Rm. 1201

300 S. New Street

Dover, Delaware 19901 


\section{CONTENTS}

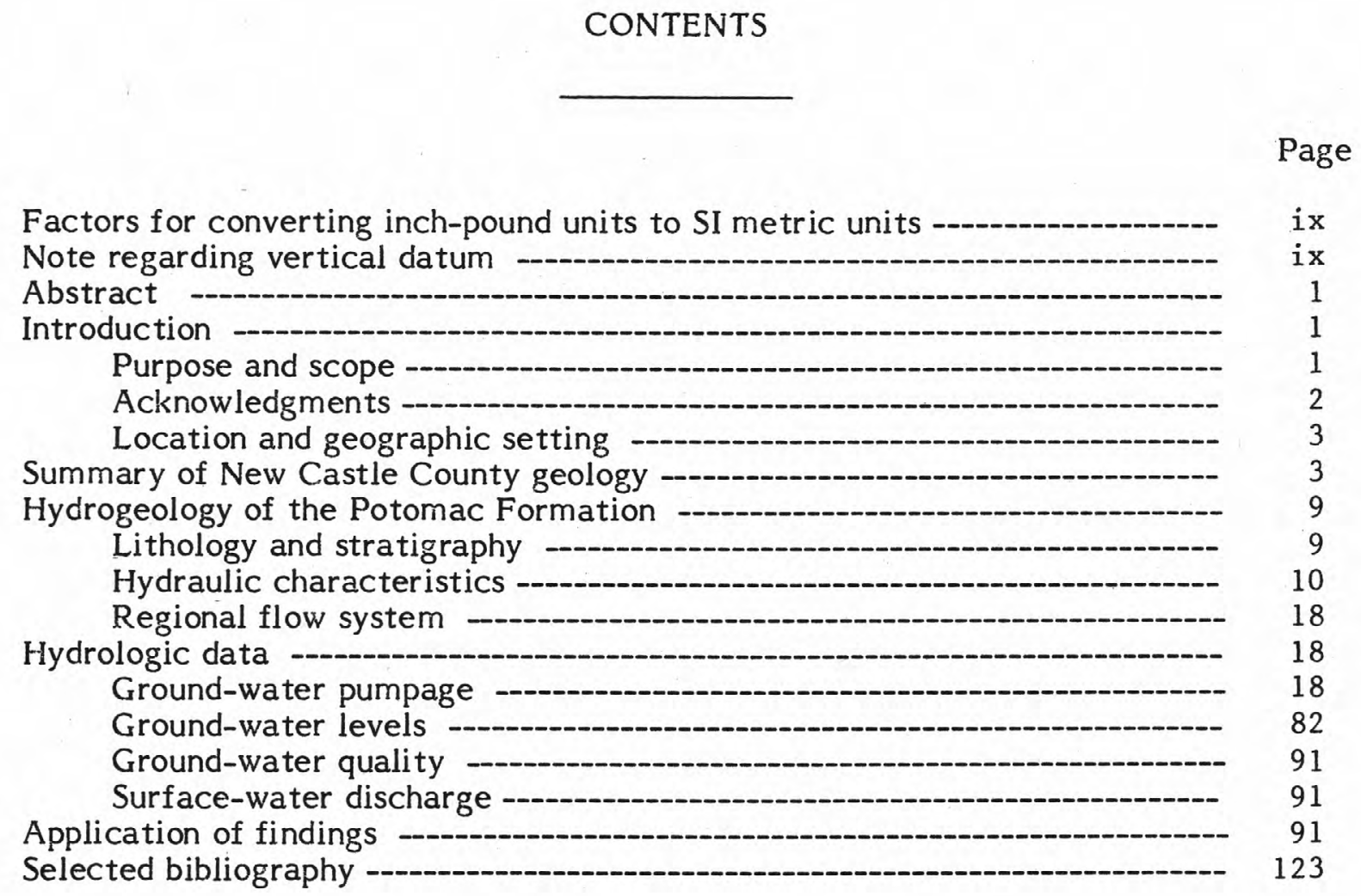

\section{ILLUSTRATIONS}

Page

Figure 1. Map showing location of study area and well fields in the Potomac Formation -

2. Map showing geology of New Castle County --

3. Structure contour map of the top of the basement crystalline rocks - - 6

4. Generalized geologic cross section of New Castle County ---

5. Map showing thickness of the Potomac Formation

6. Structure contour map of the top of the Potomac Formation ----- 12

7. Map showing location of wells with aquifer test data - 


\section{ILLUSTRATIONS--Continued}

Page

Figure 8. Map showing general water flow in the Cretaceous sediments in the northern part of the Atlantic

Coastal Plain

9. Map showing location of selected wells in the Potomac

Formation

10 - 67. Graphs showing pumpage and water levels for selected

wells in the Potomac Formation:

10. Amoco. Water levels in wells Dc15-17, Dc15-18, and Dc15-20, 1974-80

11. Amoco. Monthly pumpage from Dc15-9, Dc15-10, and Dc25-17, 1975-80

12. Amoco. Total monthly pumpage from well field, 1964-80

13. Army Creek landfill. Monthly pumpage from Dc14-33 and Dc14-34, 1973-80. Water levels in Dc14-18, 1974-80

14. Army Creek landfill. Monthly pumpage from Dc14-35 and Dc14-36, 1973-80, and Dc14-47, 1974-80. Water levels in Dc14-46, 1974-80

15. Army Creek landfill. Monthly pumpage from Dc14-48 and Dc14-49, 1974-80. Water levels in Dc14-41 and Dc24-22, 1974-80

16. Army Creek landfill. Monthly pumpage in Dc14-50 and Dc14-51, 1974-80. Water levels in Dc14-37 and Dc14-19, 1974-80

17. Army Creek landfill. Monthly pumpage in Dc24-36 and Dc24-38, 1974-80. Water levels in Dc24-37 and Dc24-39, 1974-80

18. Army Creek landfill. Total monthly pumpage from well field, 1973-80. Water levels in Dc15-15, Dc25-23, and Dc25-24, 1975-80

19. Caravel Farms. Total monthly pumpage from well field, 1978-80. Water levels in Db52-23, 1976-80, and Db52-27, 1978-80

20. Castle Hills. Water levels in Cd42-18, Cd52-15, and $\mathrm{Cd} 52-28,1973-80$

21. Castle Hills. Total monthly pumpage from well field, 1958-80 


\section{ILLUSTRA TIONS--Continued}

Page

Figure 22. Collins Park. Total monthly pumpage from well

field, 1958-72

23. Collins Park. Total monthly pumpage from well

field, 1973-80. Water levels in Cd42-16 and

Cd42-17, 1978-80, and Cd42-15, 1973-78

24. Delmarva Power - Summit. Water levels in

Eb45-10, 1975-79, and Eb44-9, 1979-80

25. du Pont - Newport. Water levels in Cc34-36, 1975-80, and Cc34-37 and Cc34-38, 1976-80

26. du Pont - Newport. Monthly pumpage from Cc34-14 and Cc34-15 and total monthly pumpage from well field, 1975-80

27. Fairwinds. Water levels in Dc22-13 and Dc22-18, 1974-80, and Dc22-14, 1973-80

28. Fairwinds. Water levels in Dc22-22, Dc22-24, and Dc23-16, 1973-80

29. Fairwinds. Total monthly pumpage from well field, 1964-80. Water levels in Dc23-17, 1973-80

30. Getty. Water levels in Dc51-9, 1960-80, and Ecl2-2, 1958-60 and 1976-80

31. Getty. Water levels in Dc53-7, 1954-80

32. Getty. Water levels in Eb15-4, 1955-80

33. Getty. Monthly pumpage from Dc41-4 and Dc51-7, 1976-80, and Dc42-6, 1974-80

34. Getty. Monthly pumpage from Dc52-24 and Ec12-20, 1976-80, and Ebl5-4, 1974-80

35. Getty. Monthly pumpage from Ec13-6, 1974-80, and Ec14-7 and Ec22-3, 1976-80

36. Getty. Total monthly pumpage from well field, 1955-80

37. Glendale. Water levels in Dc31-10 and Dc31-13, 1973-80, and Dc31-18, 1976-80

38. Glendale. Water levels in Dc31-21, 1974-80, and Dc31-24, 1976-80

39. Glendale. Total monthly pumpage from well field, 1973-80. Water levels in Dc31-26 and Dc31-27, 1973-80 


\section{ILLUSTRATIONS--Continued}

Page

Figure 40. Goodrich. Water levels in Ea33-1, 1966-80 - 56

41. ICI. Monthly pumpage from Cd44-14, 1973-80.

Water levels in Cd44-14, 1976-80

42. Jefferson Farms. Water levels in Cd51-13 and

Cd51-15, 1973-80, and Cd51-14, 1976-80

43. Jefferson Farms. Total monthly pumpage from well field, 1962-80

44. Llangollen Estates. Water levels in Dc23-2, Dc23-10, and Dc24-18, 1973-80

45. Llangollen Estates. Water levels in Dc24-40 and Dc24-41, 1973-80

46. Llangollen Estates. Total monthly pumpage from well field, 1958-80

47. Midvale. Water levels in Dc12-10 and Dc13-10, 1976-80, and Dcl4-3, Dc14-53, and Dcl4-54, 1973-80

48. Midvale. Total monthly pumpage from well field, 1958-80

49. National Guard rifle range. Water levels in Dc34-5 and Dc34-6, 1975-80

50. Newark. Total monthly pumpage from well field, 1975-80

51. Newark. Monthly pumpage from Ca55-3 and Ca55-5, 1975-80. Water levels in Ca55-3 and $\mathrm{Ca} 55-5,1976-80$

52. Newark. Monthly pumpage from Dbl1-49 and

Db12-27, 1975-80. Water levels in Db11-49,

1975-80, and Db12-27, 1976-80

53. Newark. Monthly pumpage from Db22-42, 1975-80, and Db32-16, 1977-80. Water levels in Db22-42, 1976-80, and Db32-16, 1977-80

54. New Castle. Monthly pumpage from C.c55-17, 1972-80, and Dc15-16, 1978-80. Water levels in Cc55-17 and Dc15-16, 1976-80

55. New Castle. Monthly pumpage from Cd51-8, 1963-80. Water levels in Cd51-8, 1976-80

56. New Castle. Monthly pumpage from Cd52-13, 1952-72. Water levels in Cd52-14, 1950-57 


\section{ILLUSTRATIONS--Continued}

Page

Figure 57. New Castle. Monthly pumpage from Cd52-13, 1973-75, and Cd52-27, 1975-80. Water levels in $\mathrm{Cd} 52-26$ and $\mathrm{Cd} 52-27,1976-80$

58. New Castle. Total monthly pumpage from well field, 1952-80

59. Ommelanden Park. Water levels in Dc33-5, Dc33-6, and Dc34-8, 1976-80 74

60. Smalley's Dam. Water levels in Db15-5, 1976-80 74

61. Tuxedo Park. Total monthly pumpage from well field, 1955-75

62. Union Carbide. Water levels in Ec32-3, 1966-80 -

63. Union Carbide. Water levels in Ec32-7, 1966-80 -

64. Wilmington Airport. Total monthly pumpage from well field, 1976-80. Water levels in Cc45-1, Cc45-2, and Cc55-1, 1976-80

65. Wilmington Manor. Total monthly pumpage from well field, 1958-71

66. Wilmington Manor Gardens. Water levels in Cd51-1, Cd51-11, and Cd51-12, 1973-80

67. Wilmington Manor Gardens. Total monthly pumpage from well field, $1958-80$

68. Map showing location of selected streamflow measuring sites

$69-80$. Hydrographs of stream discharge at selected surfacewater stations in New Castle County for water years 1979 and 1980

69. 01478040 , Christina River near Bear, 1979

70. 01478040, Christina River near Bear, 1980

71. 01482200, Army Creek at State Road, 1979

72. 01482200 , Army Creek at State Road, 1980

73. 01482298, Red Lion Creek near Red Lion, 1979

74. 01482298 , Red Lion Creek near Red Lion, 1980

75. 01483170 , Drawyer Creek Tributary near Odessa, 1979

76. 01483170 , Drawyer Creek Tributary near Odessa, 1980 


\section{HLUSTRATIONS--Continued}

Page

Figure

77. 01483200, Blackbird Creek at Blackbird, 1979

78. 01483200, Blackbird Creek at Blackbird, 1980

79. 01495800, Long Creek near Chesapeake City, 1979

80. 01495800, Long Creek near Chesapeake City, 1980

\section{TABLES}

Table 1. Generalized stratigraphic units of the Coastal Plain in Maryland, Delaware, and New Jersey

2. Transmissivities, coefficients of storage, and confining bed vertical hydraulic conductivities for the Potomac Formation as determined by aquifer tests in New Castle County, Del.

3. Pumpage from the Potomac Formation in New Castle County, Del.

4. Water levels in the Potomac Formation in New Castle County, Del.

5. Chemical analyses of water from the Potomac

Formation in New Castle County, Del.

6. Low-flow discharge at selected surface-water stations in New Castle County, Del.

7. Partial records of wells in the Potomac Formation in New Castle County, Del. 
Inch-pound unit

cubic foot per second $\left(\mathrm{ft}^{3} / \mathrm{s}\right)$

cubic foot per second per square mile

$\left[(\mathrm{ft} / \mathrm{s}) / \mathrm{mi}^{2}\right]$

foot $(f t)$

foot per day $(f t / d)$

foot squared per day $(\mathrm{ft} / \mathrm{d})$

gallon per minute (gal/min)

gallon per minute per foot $[(\mathrm{gal} / \mathrm{min}) / \mathrm{ft}]$

inch (in)

micromho ( $\mu \mathrm{mho})$

million gallons (Mgal)

million gallons per day (Mgal/d)

mile (mi)

square mile $\left(\mathrm{mi}^{2}\right)$
Multiply by

0.02832

0.01093

0.3048

0.3048

0.0929

0.06309

0.207

2.54

1.00

3785

3785

2.590 $\underline{\text { Metric unit }}$

cubic meter per second $\left(\mathrm{m}^{3} / \mathrm{s}\right)$

cubic meter per second per square kilometer $\left[\left(\mathrm{m}^{3} / \mathrm{s}\right) / \mathrm{km}^{2}\right]$

meter $(\mathrm{m})$

meter per day $(\mathrm{m} / \mathrm{d})$

meter squared per day $\left(\mathrm{m}^{2} / \mathrm{d}\right)$

liter per second

$$
(\mathrm{L} / \mathrm{s})
$$

liter per second per meter $[(\mathrm{L} / \mathrm{s}) / \mathrm{m}]$

centimeter $(\mathrm{cm})$

microsiemen ( $\mu \mathrm{S})$

cubic meters $\left(\mathrm{m}^{3}\right)$

cubic meters per day $\left(\mathrm{m}^{3} / \mathrm{d}\right)$

kilometer $(\mathrm{km})$

square kilometer $\left(\mathrm{km}^{2}\right)$

\section{NOTE REGARDING VERTICAL DATUM}

The national geodetic vertical datum of 1929 , the reference surface to which relief features and altitude data are related, and formerly called mean sea level, is referred to as sea level throughout this report. 

IN NEW CASTLE COUNTY, DELAW ARE

by Mary M. Martin and Judith M. Denver

\begin{abstract}
Hydrologic data for the Potomac Formation in New Castle County, Delaware, consist of records of historical ground-water pumpage, water levels, water quality, and surface-water discharge. This report includes records of 405 wells and hydrographs of water levels in 86 wells. Pumpage from 20 well fields is reported. Also included are stream-discharge hydrographs for 6 stations for water years 1979 and 1980 and historical low-flow measurements for 22 stations.

In the analysis of 23 aquifer tests, transmissivity and storage coefficient values for the Potomac Formation range from 454 to 8,480 feet squared per day and $3.8 \times 10^{-3}$ to $5.6 \times 10^{-5}$, respectively. Vertical hydraulic conductivities of the confining bed range from 0.0083 to 3.2 feet per day.
\end{abstract}

\title{
INTRODUCTION
}

\section{Purpose and Scope}

The Potomac Formation is a major source of water for the cities and industries of New Castle County, Del. Withdrawal from the Potomac aquifers in 1955 was estimated to be $7.0 \mathrm{Mgal} / \mathrm{d}$ (Marine and Rasmussen, 1955, p. 89). A steady increase in Potomac pumpage over the next two decades resulted in pumpage estimated at $10.8 \mathrm{Mgal} / \mathrm{d}$ in 1965 and $18.0 \mathrm{Mgal} / \mathrm{d}$ in 1975.

Sundstrom and others (1967) documented water-level declines and the development of both regional and local cones of depression in potentiometric surfaces centered about well fields in New Castle County. Resultant changes in groundwater gradients, as well as the proximity of landfills and saltwater estuaries to the recharge areas of the Potomac Formation, have raised concern regarding the future quantity and quality of water from this formation. 
The purpose of this report is to present available hydrologic data on the Potomac Formation in New Castle County. Included in this report are a brief summary of the geologic and hydrologic characteristics of the Potomac Formation; records of historical ground-water pumpage, water levels, and water quality; and surface-water discharge hydrographs and low-flow measurements. This report is intended to assist in management decisions on water resources and in developing a digital model of the flow system in the Potomac Formation.

Data were collected from various state agencies, industries, and water companies. Data collected by the U.S. Geological Survey have been identified as such. Typically, each organization collects and reports hydrologic data by their own methods. The lack of standardized collecting and reporting techniques has resulted in several inconsistencies in this report. Wells may be identified by more than one well-numbering system, altitude and water levels are reported to various degrees of accuracy, and pumpage and water-level data are not continuous through time. The well records included in this report were compiled primarily to identify Potomac wells and aid in identifying the location of Potomac sands by use of the wells' screen interval. More detailed well records are maintained by the Delaware Geological Survey and the U.S. Geological Survey in Delaware.

Wells in this report are identified by the number assigned to them by the Delaware Geological Survey (DGS). Wells without an assigned DGS number are identified by a local number. For each well field, wells are listed alpha-numerically by DGS number, then by local number. In each table, wells are listed under their appropriate well-field name. Well-field names are listed alphabetically. Wells shown in figures 3 through 6 were used by Sundstrom and Pickett (1971, p. 14-17) to define New Castle County geology. These wells are not necessarily screened in the Potomac Formation and therefore may not be included in the tabulation of well records.

Additional data from selected areas in nearby Cecil County, Md., are included. Data for selected wells at the Goodrich well field in Cecil County can be found listed under the well-field name in the appropriate sections of this report. Two surface-water stations in Cecil County are identified by their index numbers. These wells and surface-water sites are shown on the appropriate location maps. However, because of the limited documentation of hydrologic data from Maryland in this report, Maryland data are included with data for New Castle County, Del.

\section{Acknowledgments}

This report is part of a study of the Potomac Formation in New Castle County, Del., by the U.S. Geological Survey in cooperation with the U.S. Army Corps of Engineers and Delaware Department of Natural Resources and Environmental Control. Thanks are given to the staff of the Delaware Geological Survey for their technical assistance in this study.

Special thanks are given the following for their cooperation and assistance in supplying data: B. T. Lakshman, Chief Engineer of the Artesian Water Co.; Amoco Chemicals Corp.; Getty Refining and Marketing Co.; and the Water Department of the city of Newark. Thanks are also given to those municipalities and industries that supplied information through their cooperation with the Delaware Department of Natural Resources and Environmental Control and the Delaware Geological Survey. 


\section{Location and Geographic Setting}

The study area shown in figure 1 encompasses that part of the Atlantic Coastal Plain in New Castle County, Del., in which Potomac Formation water is usable. Crystalline rocks of the Appalachian Piedmont form the northern boundary of the area and underlie the Coastal Plain sediments. The southern boundary is a southwest-trending line through the town of Blackbird, which approximates the downdip limit of freshwater in the Potomac Formation proposed by Cushing and others in 1973. Major features are the Delaware River and its estuaries along the eastern boundary and the Chesapeake and Delaware Canal, which bisects the area from east to west.

The Coastal Plain sediments form broad, very gently rolling or flat plains. Relief is slight, as altitudes range from 100 feet above sea level near the Fall Zone, the junction between the Piedmont and Coastal Plain provinces, to sea level along the Delaware River. Precipitation averages 46 inches per year.

\section{SUMMARY OF NEW CASTLE COUNTY GEOLOGY}

The following summary has been adapted from the general descriptions of Delaware and New Castle County geology by Sundstrom, Pickett, and Varrin (1975, p. 10-19) and Sundstrom and Pickett (1971, p. 7-33). More detailed works on the geology of New Castle County are referenced in the bibliography.

Figure 2 is a geologic map of New Castle County. The igneous and metamorphic rocks of the Piedmont are the oldest rocks in the State. These rocks, described by Spoljaric (1972), are probably of late Precambrian or early Paleozoic age. North of the Fall Zone, these crystalline rocks are mantled by a weathered zone. South of the Fall Zone, Coastal Plain sediments overlie the weathered zone, and the Piedmont rocks form the crystalline basement. A structure contour map of the crystalline basement is shown in figure 3. Iron Hill and Chestnut Hill, $2 \mathrm{mi}$ south of Newark, are outliers of crystalline rock surrounded by Coastal Plain sediments.

The Coastal Plain sediments have been divided into the units shown in table 1. These form a wedge of unconsolidated and semiconsolidated sediments that thicken from $0 \mathrm{ft}$ at the Fall Zone to 2,400 ft in southeast New Castle County. A cross section of the Coastal Plain sediments in New Castle County is shown in figure 4.

The oldest of the Coastal Plain sediments in New Castle County form the Potomac Formation. These Early Cretaceous to early Late Cretaceous sediments were deposited by streams on crystalline basement rock. They consist of variegated clay with interbedded sand, which are highly variable in lateral extent. After a period of erosion or nondeposition, the Magothy Formation was deposited in a transitional marine environment during Late Cretaceous time. 


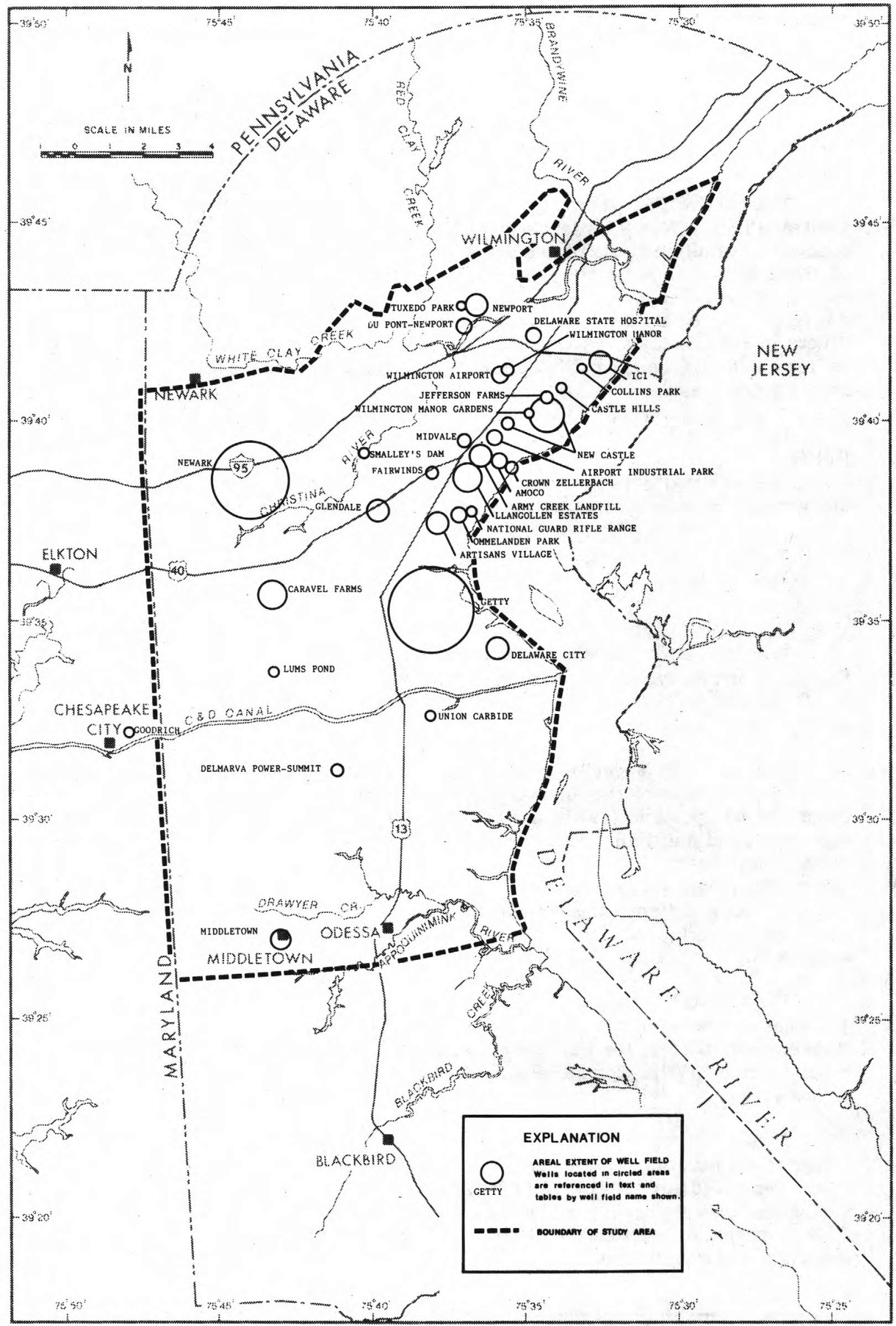

FIGURE 1.--Location of study area and well fields in the Potomac Formation. 


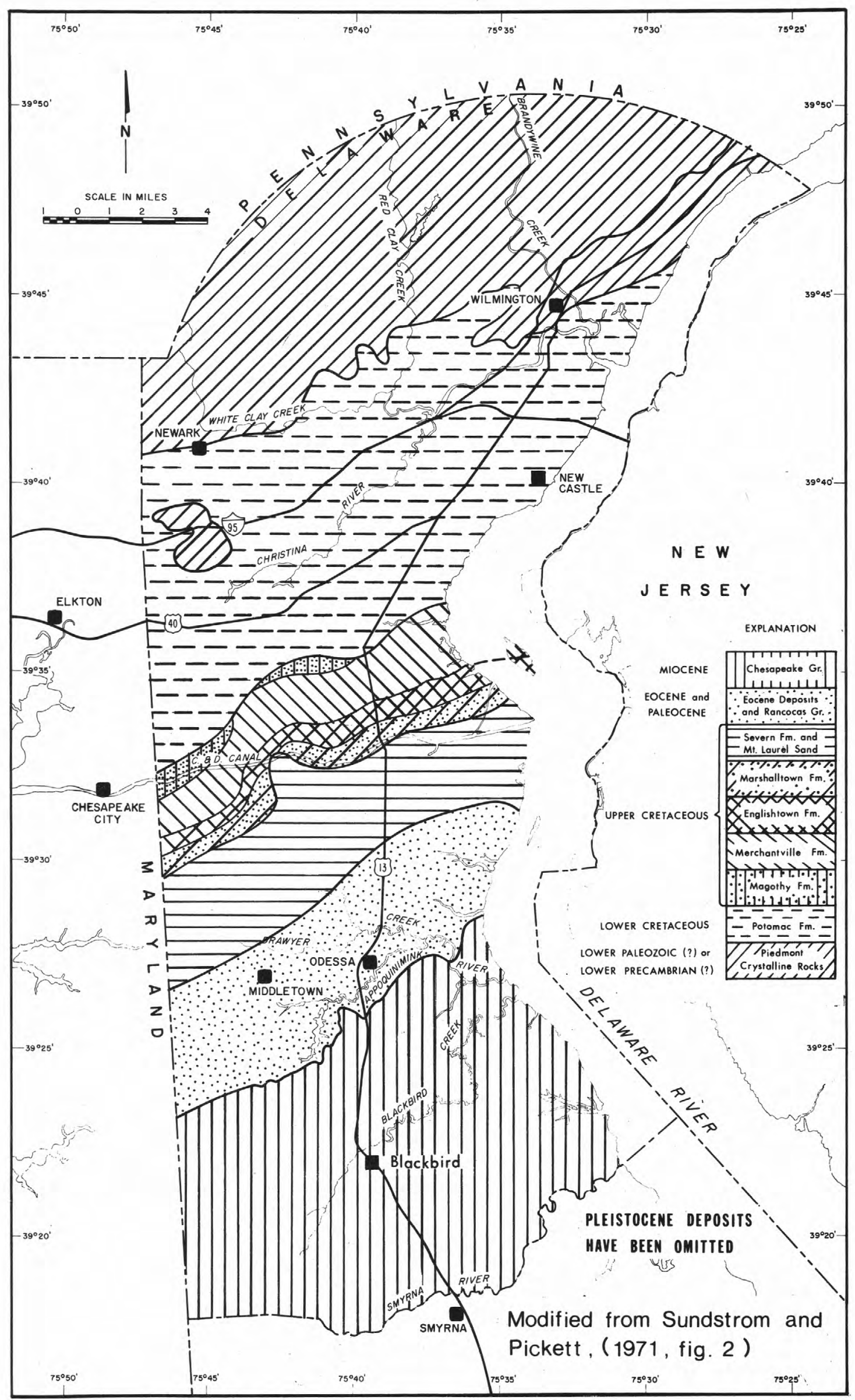

FIGURE 2.--Geology of New Castle County. 


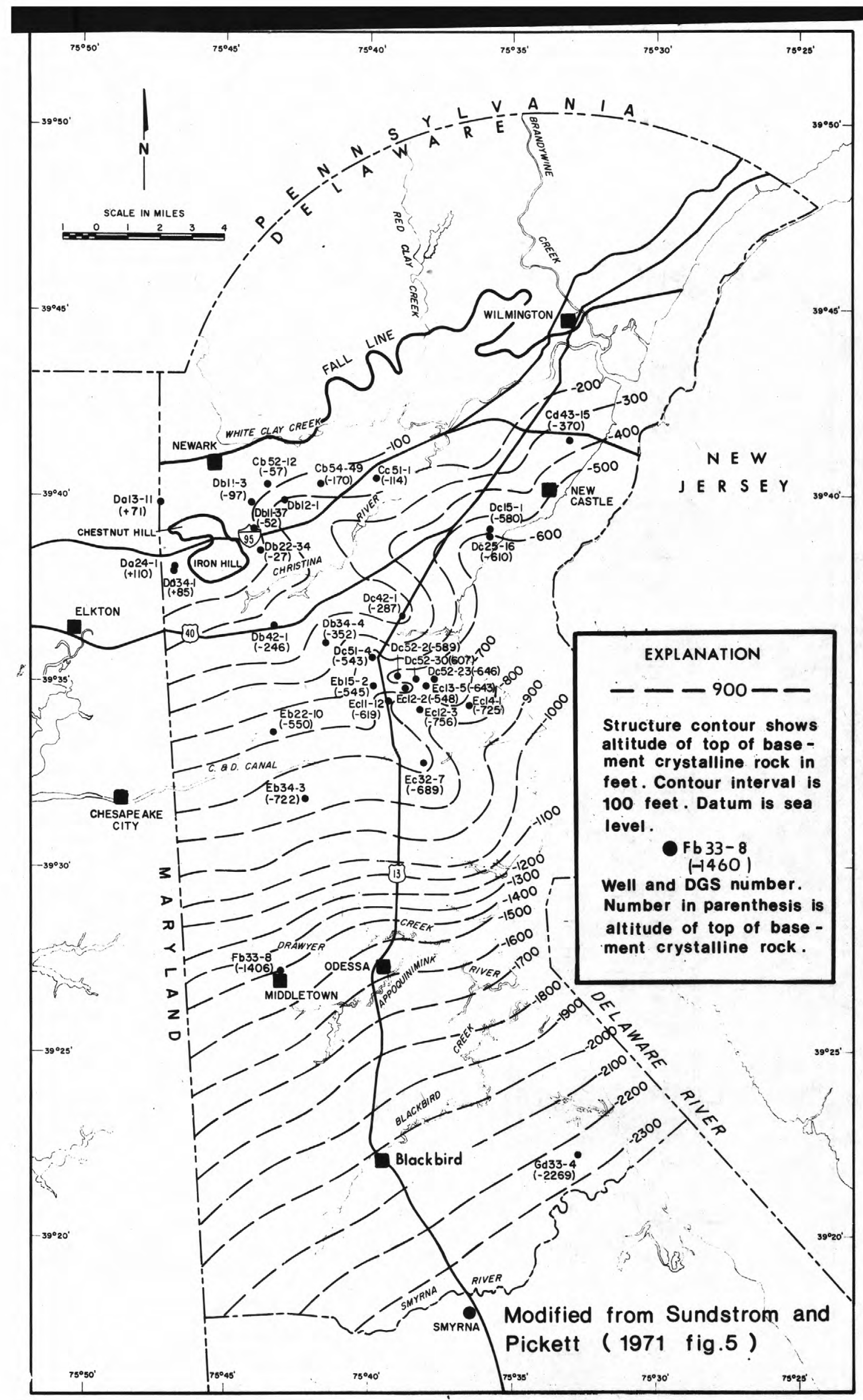

FIGURE 3.--Structure contour map of the top of the basement crystalline rocks. 
TABLE 1. Generalized seratirraphic units of the Coastal plain in Maryland, Delaware, and New Jersey.

\begin{tabular}{|c|c|c|c|c|c|c|}
\hline \multirow{2}{*}{ System } & \multirow[b]{2}{*}{ Series } & \multicolumn{5}{|c|}{ Stratigraphic Units } \\
\hline & & & Maryland & & Delaware & New Jersey \\
\hline \multirow[b]{2}{*}{ Quaternary } & Holocene & & $\cdots+\cdots$ & & $\cdots+-$ & $\cdots+\cdots$ \\
\hline & Pleistocene & & $\begin{array}{l}\text { Columbia Group } \\
\text { undivided }\end{array}$ & & $\begin{array}{l}\text { Columbia Group } \\
\text { undivided }\end{array}$ & $\begin{array}{l}\text { Undifferentiated } \\
\text { deposits } \\
\text { Cape May Formation }\end{array}$ \\
\hline \multirow{6}{*}{ Tertiary } & Pliocene & & $\begin{array}{l}\text { Undifferentiated } \\
\text { deposits }\end{array}$ & & $\begin{array}{l}\text { Undifferentiated } \\
\text { deposits }\end{array}$ & $\begin{array}{l}\text { Undifferentiated } \\
\text { deposits }\end{array}$ \\
\hline & \multirow[b]{2}{*}{ Miocene } & & Brandywine Formation & \multirow{2}{*}{\multicolumn{2}{|c|}{$\begin{array}{l}\text { Chesapeake Group } \\
\text { undivided }\end{array}$}} & \multirow{3}{*}{$\begin{array}{l}\text { Pensauken Formation } \\
\text { Bridgeton Formation } \\
\text { Cohansey Sand } \\
\text { Kirkwood Formation }\end{array}$} \\
\hline & & 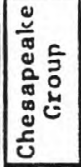 & $\begin{array}{l}\text { St. Marys Formation } \\
\text { Choptank Formation } \\
\text { Galvert Formation }\end{array}$ & & & \\
\hline & Oligocene & \multicolumn{4}{|c|}{ 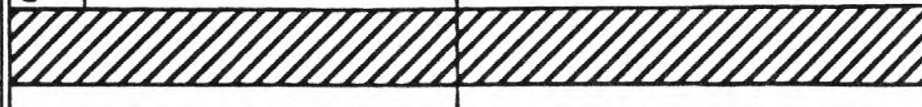 } & \\
\hline & Eocene & & $\begin{array}{l}\text { Piney Point Formation } \\
\text { Nanjemoy Formation }\end{array}$ & & $\begin{array}{l}\text { Piney Point Formation } \\
\text { Nanjemoy Formation }\end{array}$ & $\begin{array}{l}\text { Piney Point Formation } \\
\text { Shark River Formation } \\
\text { Manasquan Formation }\end{array}$ \\
\hline & Paleocene & & $\begin{array}{l}\text { Aquia Formation } \\
\text { Brightseat Formation }\end{array}$ & 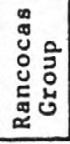 & $\begin{array}{l}\text { Vincentown Formation } \\
\text { Hornerstown Sand, }\end{array}$ & $\begin{array}{l}\text { Vincentown Formation } \\
\text { :Jornerstown Sand }\end{array}$ \\
\hline \multirow{4}{*}{ Cretaceous } & \multirow{3}{*}{$\begin{array}{c}\text { Upper } \\
\text { Cretaceous }\end{array}$} & & \multirow{3}{*}{$\begin{array}{l}\text { Severn Formation } \\
\text { Natawan Formation }\end{array}$} & & Mount Laurel Sand & \multirow{4}{*}{$\begin{array}{l}\text { Tinton Sand } \\
\text { Red Bank Sand } \\
\text { Navesink Formation } \\
\text { Mount Laurel Sand } \\
\text { Wenonah Formation } \\
\text { Marshall town Formation } \\
\text { Englishtown Formation } \\
\text { Noodbury Clay } \\
\text { Merchantville Formation } \\
\text { Magothy Formation }\end{array}$} \\
\hline & & & & 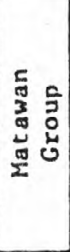 & $\begin{array}{l}\text { Marshalltown Formation } \\
\text { Englishtown Formation } \\
\text { Merchantville Formation }\end{array}$ & \\
\hline & & & & & Magothy Formation & \\
\hline & $\begin{array}{c}\text { Lower } \\
\text { Cretaceous }\end{array}$ & 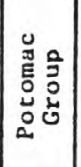 & $\begin{array}{l}\text { Patapsco Formation } \\
\text { Arundel Formation } \\
\text { Patuxent Formation }\end{array}$ & & Potomac Formation & \\
\hline
\end{tabular}

EXPLANATION

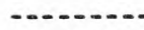

No naze assigned

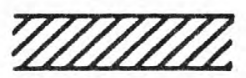

Section not present

Modified from Cushing. Owens, and Denny (1979, p. D18), Owens and Denny (1979a, figure 2) and :1inard and others, (USGS Builetin 1435-A, 1977, p. 132). 


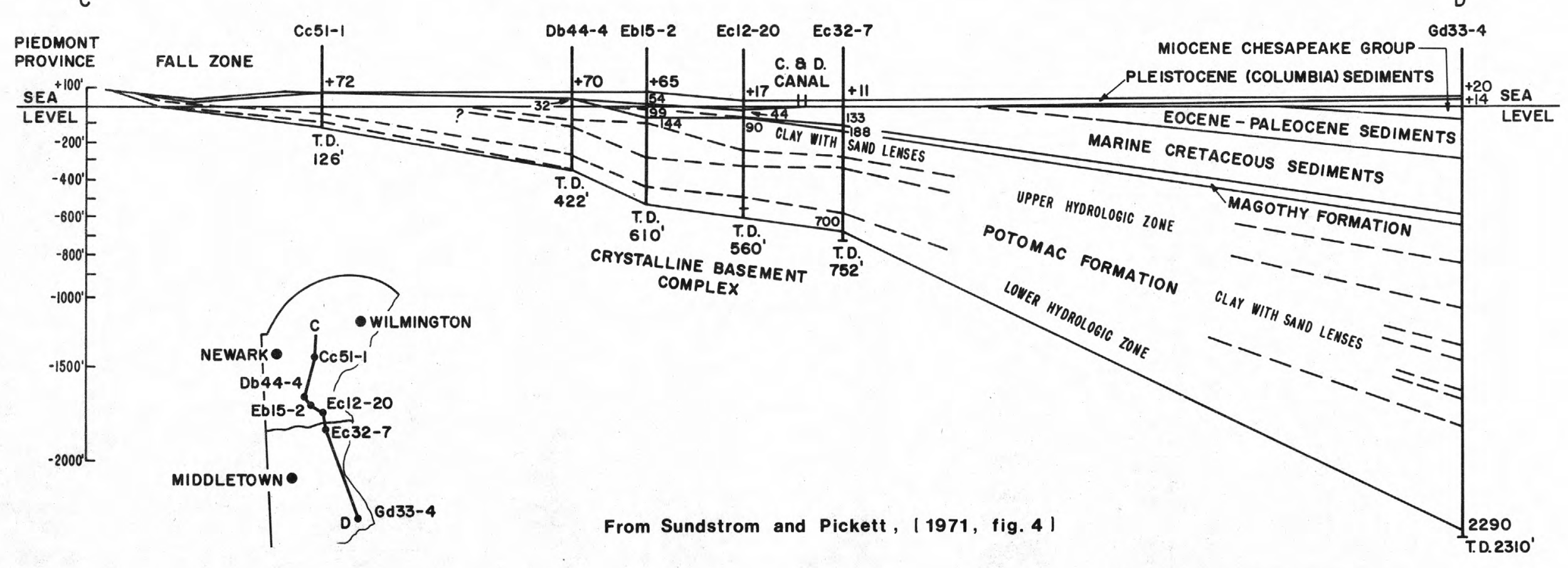

FIGURE 4.--Generalized geologic cross section of New Castle County. 
The Magothy consists of light-colored clean quartz sand beds and some clayey silt beds. Although the Magothy Formation is discontinuous along strike, the individual sand layers are less variable in thickness and lateral extent than the Potomac sand beds. The Magothy is a major aquifer in New Castle County.

Above the Magothy, the following marine units were deposited during Late Cretaceous and Paleocene times: Merchantville Formation, Englishtown Formation, Marshall town Formation, Mount Laurel Sand, Severn Formation, and the Rancocas Group. The Merchantville, Englishtown, and Marshalltown Formations make up the Matawan Group. The Merchantville is a glauconitic sandy silt and is not an aquifer. The Englishtown is a minor aquifer, less than $40 \mathrm{ft}$ thick, composed of fine well-sorted sand with interbedded layers of silty sand. The Marshalltown is a massive very glauconitic silty fine sand that is not used as an aquifer. The undivided Severn Formation and Mount Laurel Sand is glauconitic quartz sand with some silt. It is a minor aquifer and increases in thickness to $140 \mathrm{ft}$ in southern New Castle County. The Rancocas Group consists of the Horrerstown Sand and Vincentown Formation. Both units are composed of glauconitic sands and some silt. The Hornerstown is slightly coarser than the younger Vincentown.

The Nanjemoy Formation, deposited during Eocene time, is a glauconitic silt. Above the Nanjemoy, the Chesapeake Group was deposited during Miocene time. The Eocene sediments are separated from the Miocene sediments by an unconformity of Oligocene age. The Chesapeake Group is gray and tan clays, silts, and fine sands. The Eocene and Miocene units are not used as aquifers in New Castle County.

The Columbia Group or Pleistocene sediments are reddish-brown and tan and yellow medium to coarse sand and gravel beds. These sediments were deposited on the Cretaceous and Tertiary sediments after a period of erosion (Spoljaric and Woodruff, 1970, p. 68). The streams that deposited these sediments generally formed straight channels north of the canal and braided systems south of the canal (Spoljaric, 1967, p. 6).

\section{HYDROGEOLOGY OF THE POTOMAC FORMATION}

\section{$\underline{\text { Lithology and Stratigraphy }}$}

Jordan (1962, p. 6-8) gives the following summary of work done in Potomac stratigraphy until 1920. The Potomac Formation was first formally named by W. J. McGee in 1886 in the District of Columbia and adjacent parts of Maryland and Virginia. The formation was later traced by McGee through Delaware from North Carolina to New Jersey. The Potomac Formation was then mapped in Maryland and divided into the Patuxent, Arundel, Patapsco, and Raritan Formations, in ascending order. These sediments, with the exception of the Arundel Formation, were subsequently traced into Delaware. 
Informal divisions of the Potomac Formation were later developed based on lithologic and hydrologic characteristics. Groot (1955, p. 25) divided the Potomac into two zones on the basis of heavy mineral composition. The lower Patuxent zone was characterized by abundant staurolite, and the upper Patapsco-Raritan zone contained only very stable heavy minerals. Rasmussen and others (1957, p. 111-115) describe three aquifers in the nonmarine Cretaceous sediments. Designated the lower, middle, and upper aquifers, they were not considered to have time significance, but to be separate hydrologic units. Sundstrom and others (1967, p. 21) divided the Potomac Formation in the Chesapeake and Delaware Canal area of Delaware into upper and lower hydrologic zones with an intervening clay layer. These zones represented areas of relatively high sand content within the Potomac. Since Jordan's discussion of stratigraphy, the Potomac Formation in Delaware has had no formal divisions.

The Potomac Formation consists of nonmarine deposits of Early Cretaceous to early Late Cretaceous age, and was described by Jordan (1962, p. 6) as follows:

"White, gray, and rust-brown quartz sands with some gravel; variegated white, yellow, and red silts and clays, and some beds of gray clay containing finely disseminated carbonaceous matter and lignite. These are generally irregularly interbedded.

"The crystalline rocks of the Piedmont are overlain in the Coastal Plain by variegated silts and clays interbedded with sands of varying texture. Individual beds of sand or silt or clay are generally restricted in areal extent and thickness. Thus lithologic variability in both vertical and horizontal directions is a characteristic of the unit."

Sundstrom and others (1967, p. 17) state that the Potomac sediments are predominantly fine grained and were deposited by a stream system of coalescing alluvial fans. The sand layers were deposited mainly in stream channels that were not very large or persistent in location and time. The Potomac Formation typically contains small sand layers interspersed in a clay-silt matrix.

The Potomac Formation increases in thickness and depth to the southeast. A thickness map and a structure contour map of the top of the formation are shown in figures 5 and 6; respectively. In southeastern New Castle County, the Potomac Formation is more than $1,700 \mathrm{ft}$ thick, and the top of the formation is more than $650 \mathrm{ft}$ below sea level.

\section{$\underline{\text { Hydraulic Characteristics }}$}

The hydrology of the Potomac Formation in the Chesapeake and Delaware Canal area was detailed by Sundstrom and others (1967). This work was updated and extended to include all of New Castle County by Sundstrom and Pickett (1971). The variability of the hydraulic properties of the Potomac is documented in these works. 


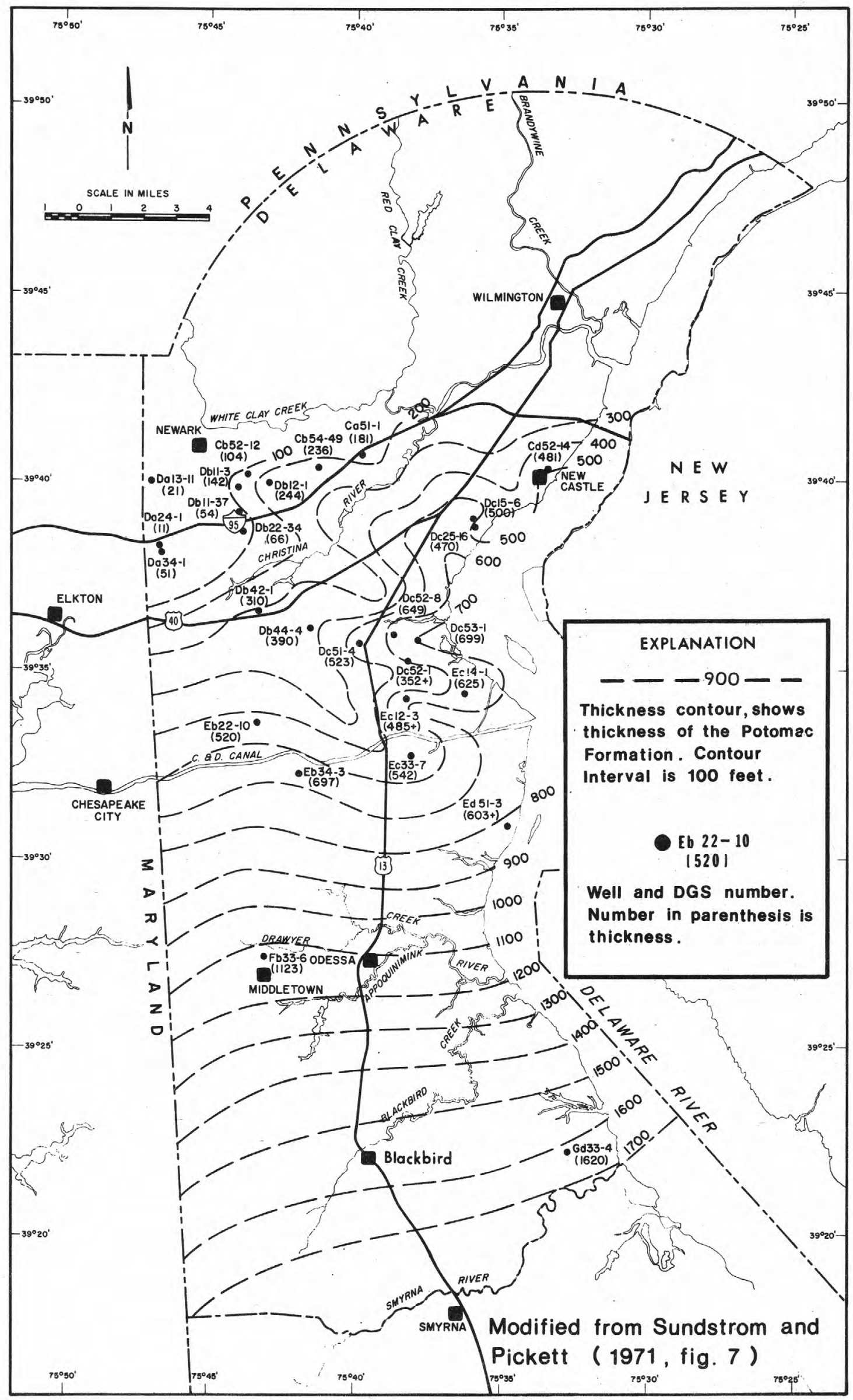

FIGURE 5.--Thickness of the Potomac Formation. 


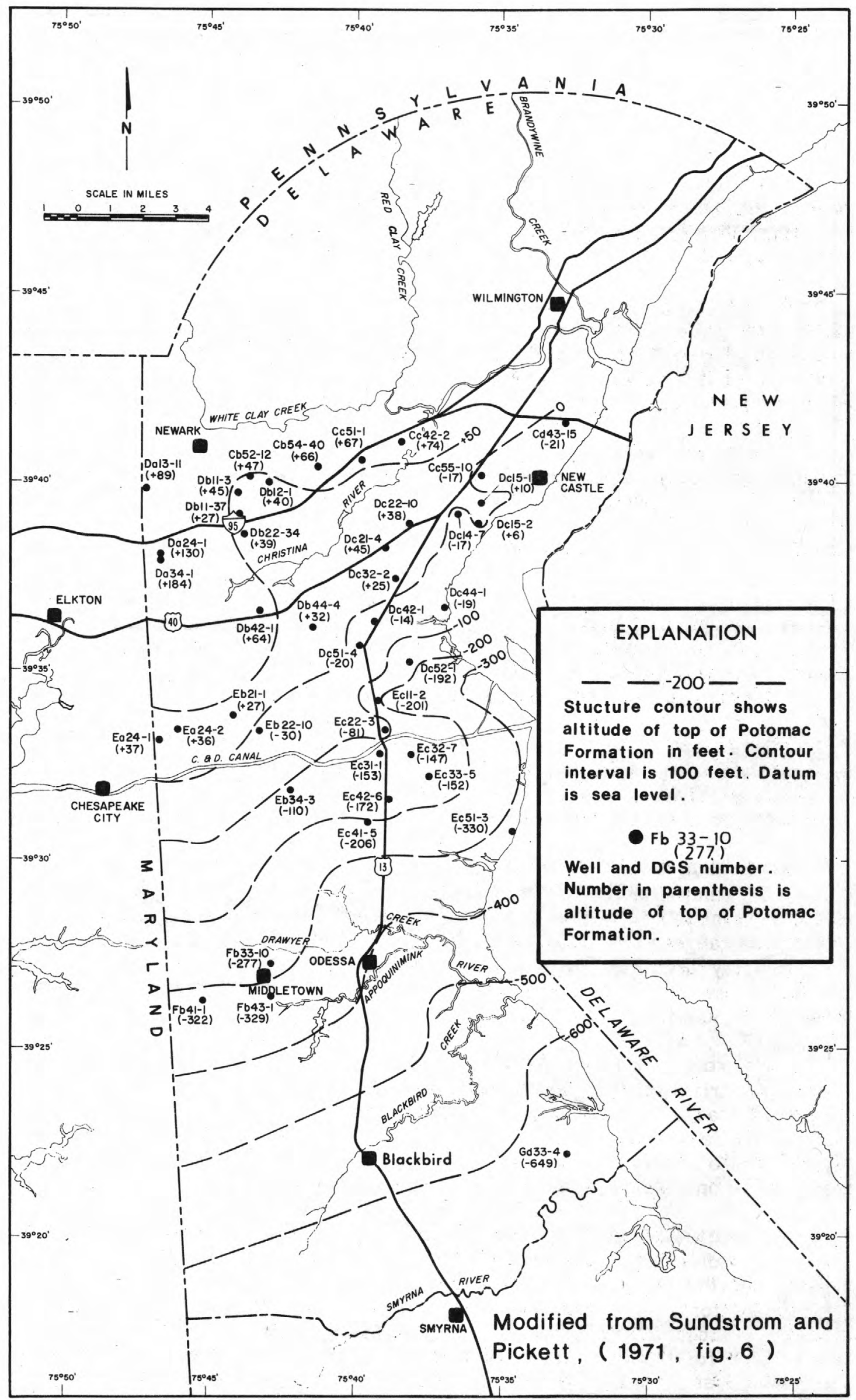

FIGURE 6.--Structure contour map of the top of the Potomac Formation. 
The concept that the Potomac Formation contains several aquifers of highly variable transmissivity separated by generally continuous confining beds is consistent with the foregoing discussion of Potomac geology. The individual sand layers that serve as aquifers were deposited within stream channels and are therefore elongate and tabular. The confining beds are finer-grained, overbank stream deposits that surround the sand bodies.

A wide range of transmissivity values are found in the analysis of aquifer tests of the Potomac Formation. Figure 7 is a location map of wells and aquifertest data. The results of the aquifer tests are given in table 2. Only aquifer tests where one or more observation wells were used have been recorded. Transmissivity values range from 454 to $8,480 \mathrm{ft}^{2} / \mathrm{d}$.

Sundstrom and Pickett (1971, p. 69-71) reported transmissivity values from wells at the Getty, Union Carbide, and Goodrich well fields ranging from 548 to $1,640 \mathrm{ft}^{2} / \mathrm{d}$. A greater number of aquifer tests are reported here than were reported by Sundstrom and Pickett. This larger sampling of aquifer properties includes transmissivity values significantly higher than those reported earlier.

The wide range of transmissivity in the Potomac sands may be caused by lateral changes in hydraulic characteristics within a sand layer or differences between separate sand layers. Locally, the depth to an aquifer sand is indicated by the depth at which wells are screened. The records of wells given in table 7 at the end of this report include the screened interval of the wells with aquifer-test data.

Storage coefficients reported in table 2 range from $3.8 \times 10^{-3}$ to $5.6 \times 10^{-5}$ and average $5.6 \times 10^{-4}$. The range of storage values reported here is similar to that reported by Sundstrom and others (1967, p. 43-45). The average value is slightly higher, but of the same order of magnitude.

Vertical hydraulic conductivities of the confining bed range from 0.0083 to $3.2 \mathrm{ft} / \mathrm{d}$. Sundstrom and others $(1967$, p. 55) reported that the coefficient of vertical permeability (hydraulic conductivity) of the intervening clayey zone in the Getty area ranges from 0.00009 to $0.0003 \mathrm{ft} / \mathrm{d}$. In table 2, the aquifer test results at the Getty area do not include confining bed properties. Vertical hydraulic conductivities of the confining bed in table 2 are significantly higher than those reported by Sundstrom and others.

Sundstrom (1974, p. 48-50) discussed vertical permeability (hydraulic conductivity) variability in relation to confining bed thickness and lateral extent. He suggested that low vertical permeability values are typical of areas such as the Getty well field, where confining beds are thick and areally continuous. He also suggested that vertical permeabilities are high in areas where confining beds are thin and discontinuous, such as Army Creek landfill.

Interpretation of all hydraulic characteristics should take into account local geologic conditions, including identification of separate sand layers, their lateral extent, and the degree of interconnection between the layers. In addition to the geologic factors, interpretation of the aquifer-test results given in table 2 should include consideration of the method of analysis and the degree to which the assumptions for that method have been met. The actual hydrologic conditions at an aquifer-test site rarely match the idealized conditions required by the equations used to analyze the test results. 


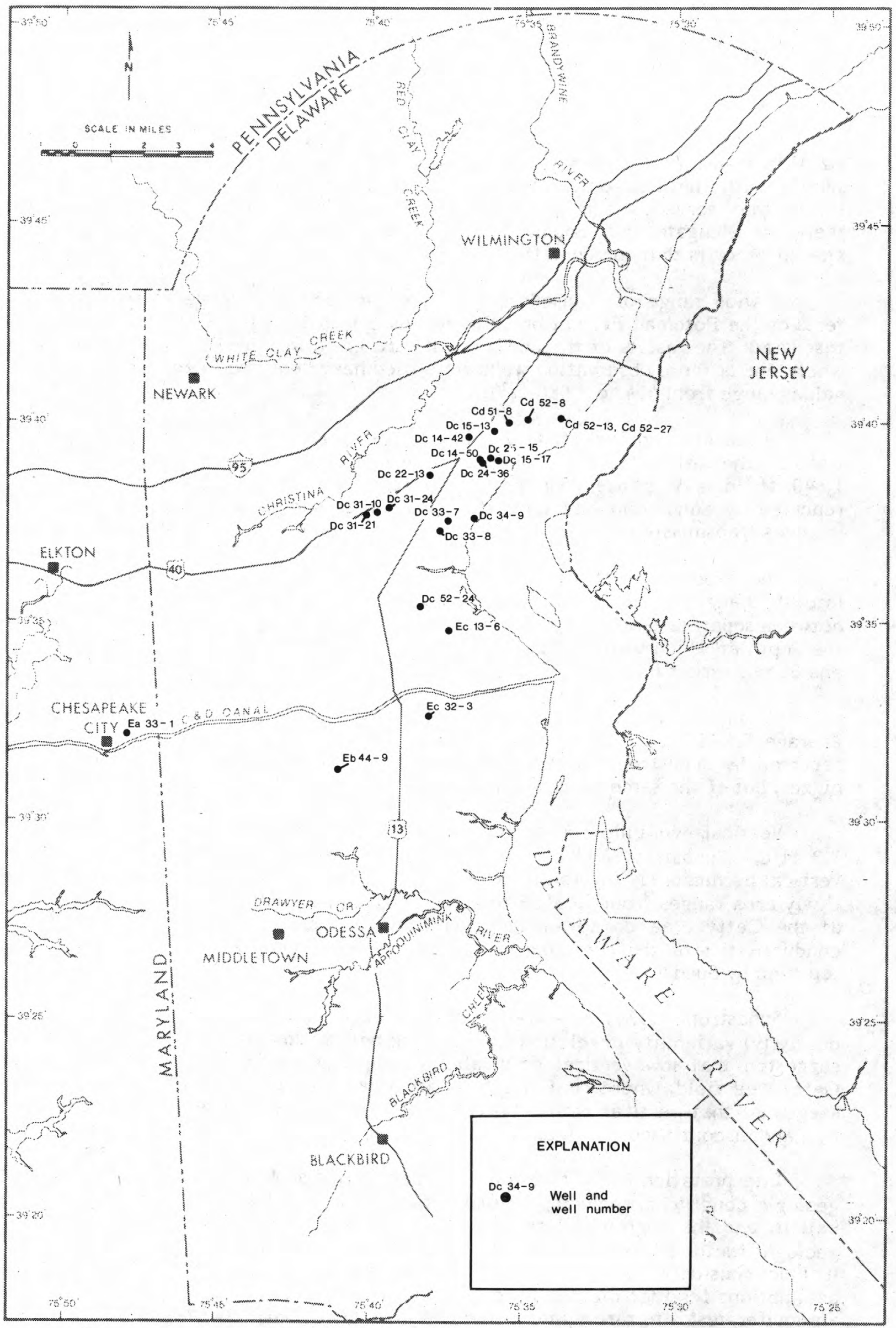

FIGURE 7.--Location of wells with aquifer test data. 
TABLE 2.--Transmissivities, coefficients of storage, and confining bed vertical hydraulic conductivities for the Potomac Formation as determined by aquifer tests in New Castle County, Del.

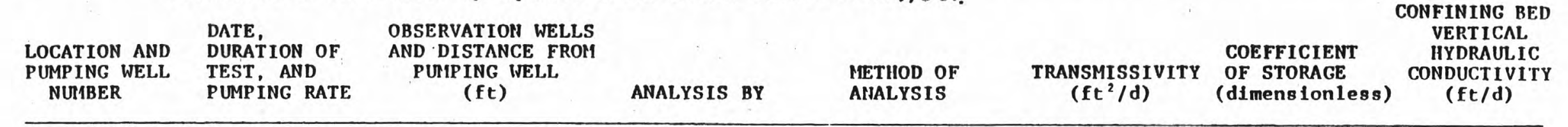

\section{Airport \\ Industrial Park \\ $\bar{D} \mathrm{c} 1 \overline{5}-1 \overline{3}$}

3-26-75
7 hours $300 \mathrm{gpm}$

Dc15-14 680

4-17-61

7 days

$1000 \mathrm{gpm}$

$\frac{\text { Amoco }}{\text { Dc25-1 }}$

Army Creek

Landf 111

Dc14-50

11-6-73

$525 \mathrm{gpm}$

Dc14-44 980

Dc23-19 460

5-6-75

24 hours

250 g pm

Dc14-45 580

Dc25-23 480

Dc23-19 1751

24 hours

$550 \mathrm{gpm}$

Artisans

Village

10-1-79 De 33-9 381

24 hours

$1075 \mathrm{gpm}$

Dc 33-8

3-24-80

275 gpm

De 32-7 3450

Delmarva Power,

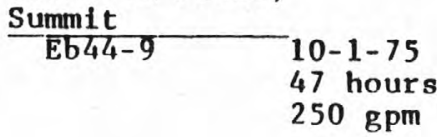

$\begin{array}{lr}\text { Eb44-10 } & 1400 \\ \text { Eb45-9 } & 80\end{array}$

$\begin{array}{lr}\text { Eb45-9 } & 80 \\ \text { Eb45-10 } & 260\end{array}$
J. M. Denver . Der

M. M. Martin

P. Williams

J. M. Denver

and

11. M. Martin

J. M. Denver and

M. M. Martin

J. M. Denver

and

M. M. Martin

J. M. Denver and

M. M. Martin

J. M. Denver and

M. M. Martin

J. M. Denver

and

M. M. Martin

\section{Stallman}

single-boundary

artesian

Hantush-Jacob

leaky artesian

Hantush-Jacob

leaky artesian

Hantush-Jacob

leaky artesian

Hantush

leaky artesian

Theis non-1eaky

artesian

Theis non-1eaky

artesian

Stallman

single-boundary

artesian
676

$1.6 \times 10^{-4}$

1180

3590

$3.8 \times 10^{-3}$

0.025

3480

3480
3830

$8.1 \times 10^{-5}$

$4 \times 10^{-4}$

0.013

1650

$8.4 \times 10^{-5}$

0.0083

3. 2

4390

$1.4 \times 10^{-6}$

1690

$1.9 \times 10^{-4}$

660

957
1143

$9.6 \times 10^{-5}$
$7.0 \times 10^{-5}$
$9.5 \times 10^{-5}$ 
TABLE 2.--Transmissivities, coefficients of storage, and confining bed vertical hydraulic conductivities for the Potomac Formation as determined by aquifer tests in New Castle County--Continued

\begin{tabular}{|c|c|c|c|c|c|c|c|}
\hline $\begin{array}{l}\text { LOCATION AND } \\
\text { PUMPING WELL } \\
\text { NUMABER }\end{array}$ & $\begin{array}{l}\text { DATE, } \\
\text { DURATION OF } \\
\text { TEST, AND } \\
\text { PUMPING RATE }\end{array}$ & $\begin{array}{l}\text { OBSERVATION WELLS } \\
\text { AND DISTANCE FROH } \\
\text { PUIPING WELL } \\
(\mathrm{ft})\end{array}$ & ANALYSIS BY & $\begin{array}{l}\text { METHOD OF } \\
\text { ANALYSIS }\end{array}$ & $\begin{array}{c}\text { TRANSMISSIVITY } \\
\left.\text { ( } \mathrm{ft}^{2} / \mathrm{d}\right)\end{array}$ & $\begin{array}{l}\text { COEFFICIENT } \\
\text { OF STORAGE } \\
\text { (dimensionless) }\end{array}$ & $\begin{array}{c}\text { CONFINING BED } \\
\text { VERTICAL } \\
\text { HYDRAULIC } \\
\text { CONDUCTIVITY } \\
\text { ( } \mathrm{ft} / \mathrm{d})\end{array}$ \\
\hline
\end{tabular}

\begin{tabular}{|c|c|c|c|}
\hline$\frac{\text { Fairwinds }}{\text { Dc } 22-13}$ & $\begin{array}{l}6-30-75 \\
72 \text { hours } \\
350 \mathrm{gpm}\end{array}$ & Dc22-18 & 475 \\
\hline$\frac{\text { Getty }}{\text { Dc52-24 }}$ & $\begin{array}{l}12-8-54 \\
7 \text { days } \\
508 \mathrm{gpm}\end{array}$ & $\begin{array}{l}\text { Dc51-3 } \\
\text { Dc51-4 } \\
\text { Dc52-6 } \\
\text { Dc52-32 } \\
\text { Dc53-6 } \\
\text { Dc53-31 } \\
\text { Ec12-15 }\end{array}$ & $\begin{array}{r}5700 \\
7900 \\
100 \\
900 \\
2000 \\
4200 \\
3800\end{array}$ \\
\hline Ec13-6 & $\begin{array}{l}1-24-55 \\
17 \text { days } \\
500 \mathrm{gpm}\end{array}$ & $\begin{array}{l}\text { Dc52-31 } \\
\text { Dc53-23 } \\
\text { Ec12-2 } \\
\text { Ec12-3 } \\
\text { Ec14-1 }\end{array}$ & $\begin{array}{l}4100 \\
1900 \\
5800 \\
5000 \\
6100\end{array}$ \\
\hline \multirow[t]{2}{*}{$\frac{\text { Glendale }}{\overline{\text { Dc } 31-10}}$} & $\begin{array}{l}6-20-73 \\
45 \text { hours } \\
524 \mathrm{gpm}\end{array}$ & Dc 31-13 & 51 \\
\hline & $\begin{array}{l}11-14-73 \\
24 \text { hours } \\
400 \mathrm{gpm}\end{array}$ & $\begin{array}{l}\text { De 31-13 } \\
\text { Dc 31-25 }\end{array}$ & $\begin{array}{r}51 \\
787\end{array}$ \\
\hline Dc 31-21 & $\begin{array}{l}4-22-74 \\
48 \text { hours } \\
310 \mathrm{gpm}\end{array}$ & $\begin{array}{l}\text { De 31-13 } \\
\text { Dc 31-25 }\end{array}$ & $\begin{array}{r}1750 \\
910\end{array}$ \\
\hline Dc $31-24$ & $\begin{array}{l}2--76 \\
24 \text { hours } \\
508 \mathrm{gpm}\end{array}$ & Dc 31-10 & 2200 \\
\hline$\frac{\text { Goodr1ch }^{2}}{\text { Ea33-1 }}$ & $\begin{array}{l}11-18-66 \\
48 \text { hours } \\
200 \mathrm{gpm}\end{array}$ & $\begin{array}{l}\text { Ea33-2 } \\
\text { Ea33-3 }\end{array}$ & $\begin{array}{l}200 \\
600\end{array}$ \\
\hline
\end{tabular}

\begin{tabular}{|c|c|}
\hline P. Will1ams & $\begin{array}{l}\text { Hantush-Jacob } \\
\text { leaky artesian }\end{array}$ \\
\hline $\begin{array}{l}\text { Leggette and } \\
\text { Brashears }\end{array}$ & $\begin{array}{l}\text { Cooper and Jacob } \\
\text { semi-log }\end{array}$ \\
\hline $\begin{array}{l}\text { Leggette and } \\
\text { Brashears }\end{array}$ & $\begin{array}{l}\text { Cooper and Jacob } \\
\text { semi-log }\end{array}$ \\
\hline $\begin{array}{l}\text { J. M. Denver } \\
\text { and } \\
\text { M. M. Martin }\end{array}$ & $\begin{array}{l}\text { Hantush-Jacob } \\
\text { leaky artesian }\end{array}$ \\
\hline $\begin{array}{l}\text { J. M. Denver } \\
\text { and } \\
\text { M. M. Martin }\end{array}$ & $\begin{array}{l}\text { Hantush-Jacob } \\
\text { leaky artesian }\end{array}$ \\
\hline $\begin{array}{l}\text { J. M. Denver } \\
\text { and } \\
\text { M. M. Martin }\end{array}$ & $\begin{array}{l}\text { Hantush-Jacob } \\
\text { leaky artesian }\end{array}$ \\
\hline P. Williams & $\begin{array}{l}\text { Stallman } \\
\text { single-boundary } \\
\text { artesian }\end{array}$ \\
\hline
\end{tabular}

$61008.2 \times 10^{-4}$


TABLE 2.--Transmissivities, coefficients of storage, and confining bed vertical hydraulic conductivitles for the Potomac Formation as determined by aquifer tests in New Castle County --Continued

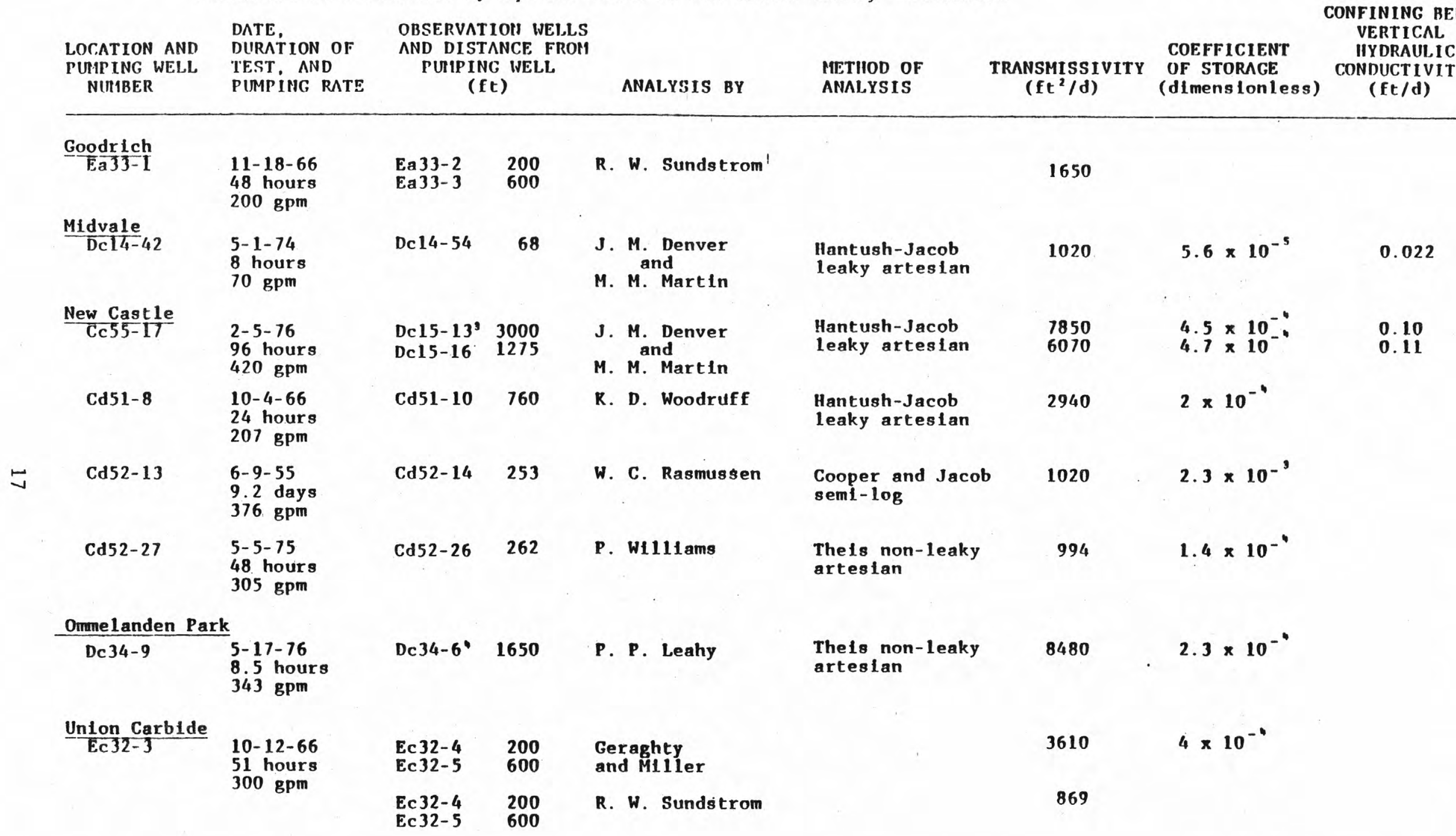

- Alrport Industrial Park

- National Guard Pifle Range 
A generalized flow pattern of ground water for the Cretaceous sediments of Delaware, Maryland, New Jersey, and Virginia is shown in figure 8 . The flow pattern, proposed by Back (1966), p. A9-A11) was developed by an electric analog model and both measured and historic water-level data. The flow pattern shown in figure 8 shows the direction of ground-water movement in two directions and does not take into account vertical leakage. Although ground water discharges upward through overlying sediments, the two-dimensional flow pattern is adequate to demonstrate important general features of ground-water movement (Back, 1966, p. A11).

Water in the Cretaceous sediments in Delaware is shown to flow from recharge areas of high head near the Fall Zone downdip to discharge areas of lower head. These discharge areas are in southern New Castle County along the saltwater interface and in Maryland and New Jersey along the interface and the Fall Zone.

The saltwater interface in figure 8 represents an estimated boundary between freshwater and saltwater with a chloride concentration of $350 \mathrm{mg} / \mathrm{L}$. In analyzing the pattern of ground-water flow, Back (1966, P. A11) considered the interface an impermeable boundary. According to Back (1966, p. A11), ground water discharges upward through overlying sediments at the interface. The limitations imposed by these assumptions must be considered when applying Back's generalized flow pattern to flow within the Potomac Formation of New Castle County.

\section{HYDROLOGIC DATA}

\section{Ground-Water Pumpage}

Before 1955, pumpage from the Potomac Formation was insignificant. During 1980, 19.9 Mgal (estimated) was withdrawn each day from Potomac aquifers in New Castle County. The greatest proportion of this pumpage is for industrial, municipal, and public water supply. Less than 10 percent of current pumpage is for irrigation or domestic use.

Table 3 shows the total yearly pumpage from the Potomac Formation for the principal well fields in New Castle County. Pumpage information was compiled from previous publications, records at the Delaware Department of Natural Resources and Environmental Control and the Delaware Geological Survey, and from information supplied by the municipalities, industries, and public water supply companies. Although some of the values given in table 3 are not exact, they are the best estimate of pumpage for the years shown. No information is available for the years not listed in table 3. Pumpage for years before those shown is not necessarily zero, but is generally insignificant. 


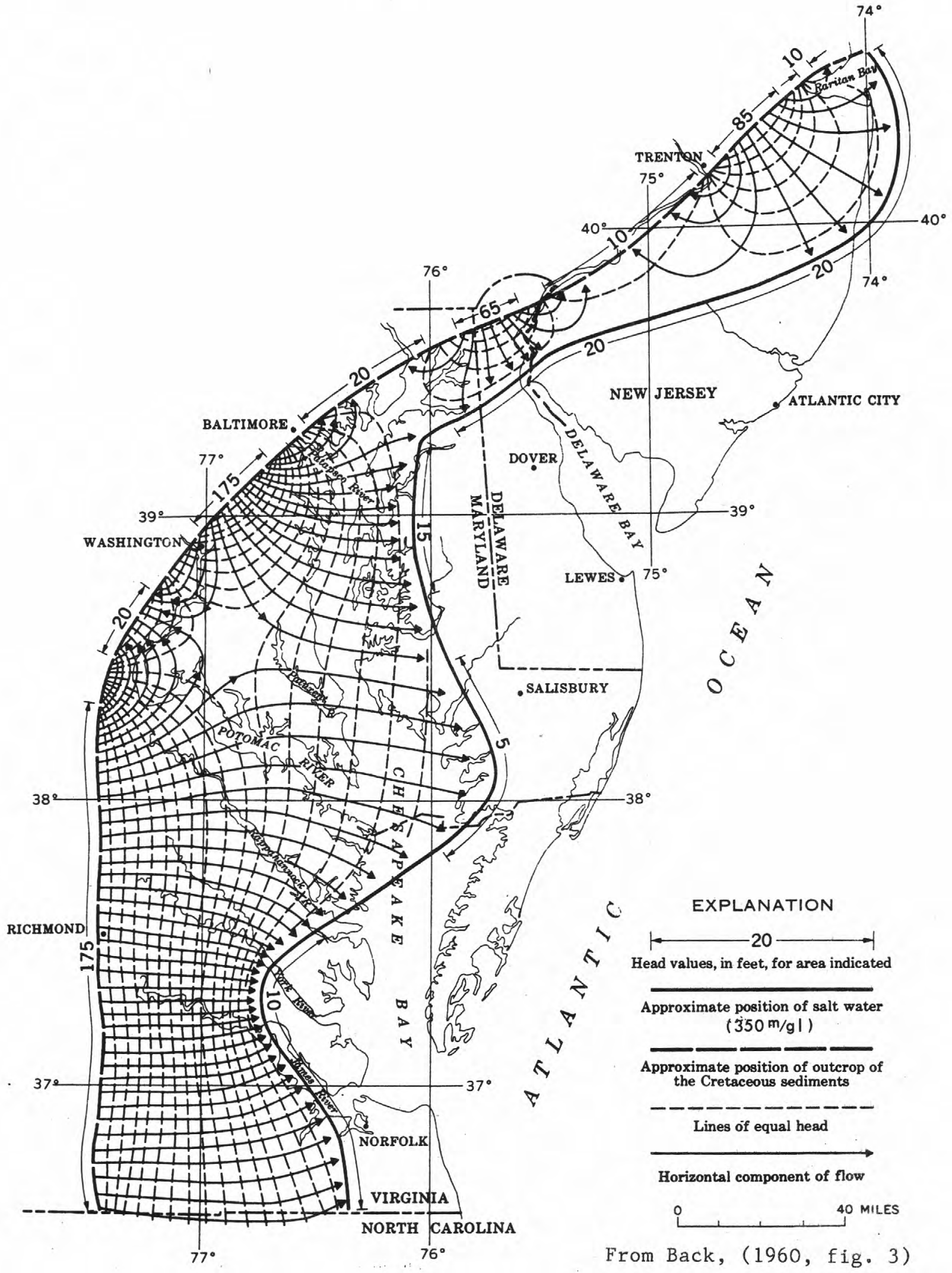

Figure 8.--General water flow in the Cretaceous sediments in the northern part of the Atlantic Coastal Plain. 
TABLE 3.--Pumpage from the Potomac Formation in New Castle County, Del.

Pumpage: In million gallons.

Status of production wells is given in Table 7:

Amoco

PRODUCTION WELLS: Dc15-9, Dc15-10, and Dc25-17.

$\begin{array}{cccccc}\text { YEAR } & \text { PUMPAGE } & \text { YEAR } & \text { PUMPAGE } & \text { YEAR } & \text { PUMPAGE } \\ 1964 & 590 & 1970 & 580 & 1976 & 424.2 \\ 1965 & 500 & 1971 & 500 & 1977 & 381.2 \\ 1966 & 465 & 1972 & 580 & 1978 & 401.6 \\ 1967 & 500 & 1973 & 660 & 1979 & 348.3 \\ 1968 & 526 & 1974 & 620 & 1980 & 287.2 \\ 1969 & 650 & 1975 & 433.3 & & \end{array}$

\section{Army Creek Landfill}

PRODUCTION WELLS: Dc14-33, Dc14-34, Dc14-35, Dc14-36, Dc14-47, Dc14-48, Dc14-49, Dc14-50, Dc14-51, Dc24-36, and Dc24-38.

$\begin{array}{rrrcrr}\text { YEAR } & \text { PUMPAGE } & \text { YEAR } & \text { PUMPAGE } & \text { YEAR } & \text { PUMPAGE } \\ 1974 & 946.7 & 1977 & 598.0 & 1979 & 572.9 \\ 1975 & 533.6 & 1978 & 456.2 & 1980 & 431.5^{1} \\ 1976 & 635.3 & & & & \end{array}$

\section{Carave1 Farms}

PRODUCTION WELL: Db52-27.

$\begin{array}{cccccc}\text { YEAR } & \text { PUMPAGE } & \text { YEAR } & \text { PUMPAGE } & \text { YEAR } & \text { PUMPAGE } \\ 1978 & 86.6 & 1979 & 95.1 & 1980 & 100.3\end{array}$

\section{Castle Hills}

PRODUCTION WELLS: Cd42-18, Cd52-15, and Cd52-28.

$\begin{array}{lccccc}\text { YEAR } & \text { PUMPAGE } & \text { YEAR } & \text { PUMPAGE } & \text { YEAR } & \text { PUMPAGE } \\ 1955 & 25.7 & 1964 & 306.1 & 1973 & 444.5 \\ 1956 & - & 1965 & 391.5 & 1974 & 464.1 \\ 1957 & 200.9 & 1966 & 410.4 & 1975 & 445.3 \\ 1958 & 248.5 & 1967 & 388.8 & 1976 & 446.8 \\ 1959 & 354.7 & 1968 & 404.1 & 1977 & 372.6 \\ 1960 & 515.6 & 1969 & 441.6 & 1978 & 410.0 \\ 1961 & 603.4 & 1970 & 482.2 & 1979 & 405.4 \\ 1962 & 525.2 & 1971 & 434.7 & 1980 & 373.9 \\ 1963 & 377.7 & 1972 & 466.6 & & \end{array}$

1 Pumpage for January through September. 
TABLE 3.--Pumpage from the Potomac Formation in New Castle County--Continued

Collins Park

PRODUCTION WELLS: Cd42-1, Cd42-3, Cd42-4, Cd42-5, Cd42-9, Cd42-13, Cd42-14, Cd42-15, and Cd42-17.

\begin{tabular}{|c|c|c|c|c|c|}
\hline YEAR & PUMPAGE & YEAR & PUMPAGE & YEAR & PUMPAGE \\
\hline $\begin{array}{l}1955 \\
1956 \\
1957 \\
1958 \\
1959 \\
1960 \\
1961 \\
1962 \\
1963\end{array}$ & $\begin{array}{r}37.9 \\
- \\
- \\
61.5 \\
80.9 \\
66.0 \\
119.5 \\
72.1 \\
29.6\end{array}$ & $\begin{array}{l}1964 \\
1965 \\
1966 \\
1967 \\
1968 \\
1969 \\
1970 \\
1971 \\
1972\end{array}$ & $\begin{array}{r}32.4 \\
25.5 \\
36.1 \\
21.2 \\
45.7 \\
102.1 \\
92.5 \\
112.8 \\
86.5\end{array}$ & $\begin{array}{l}1973 \\
1974 \\
1975 \\
1976 \\
1977 \\
1978 \\
1979 \\
1980\end{array}$ & $\begin{array}{r}96.5 \\
66.5 \\
100.1 \\
106.8 \\
117.4 \\
78.1 \\
154.9 \\
132.2\end{array}$ \\
\hline
\end{tabular}

Crown Zellerbach

PRODUCTION WELLS: Dc25-1, Dc25-2, Dc25-3, Dc25-4, Dc25-5, Dc25-6, Dc25-7, and Dc25-27.

$\begin{array}{lccccr}\text { YEAR } & \text { PUMPAGE } & \text { YEAR } & \text { PUMPAGE } & \text { YEAR } & \text { PUMPAGE } \\ 1949 & 465.0 & 1954 & - & 1977 & 82.9 \\ 1950 & 464.9 & 1955 & 225 & 1978 & 106.9 \\ 1951 & 432.7 & & & 1979 & 186.3 \\ 1952 & 45.4 & 1975 & 140.0 & 1980 & 122.0^{2} \\ 1953 & 213.84 & 1976 & 140.0 & & \end{array}$

du Pont - Newport

PRODUCTION WELLS: Cc34-14, Cc34-15, and Cc34-19.

$\begin{array}{rrrrrr}\text { YEAR } & \text { PUMPAGE } & \text { YEAR } & \text { PUMPAGE } & \text { YEAR } & \text { PUMPAGE } \\ 1975 & 26.28 & 1977 & 31.20 & 1979 & 15.83 \\ 1976 & 24.34 & 1978 & 22.04 & 1980 & 14.98^{2}\end{array}$

\section{Fairwinds}

PRODUCTION WELLS: Dc22-13, Dc22-14, Dc22-22, Dc22-23, Dc22-24, Dc23-11, and Dc23-17

$\begin{array}{lccccc}\text { YEAR } & \text { PUMPAGE } & \text { YEAR } & \text { PUMPAGE } & \text { YEAR } & \text { PUMPAGE } \\ 1964 & 126.2 & 1970 & 762.6 & 1976 & 813.6 \\ 1965 & 362.3 & 1971 & 698.3 & 1977 & 739.3 \\ 1966 & 694.7 & 1972 & 773.0 & 1978 & 686.1 \\ 1967 & 806.8 & 1973 & 817.7 & 1979 & 590.0 \\ 1968 & 856.3 & 1974 & 773.6 & 1980 & 740.2 \\ 1969 & 865.1 & 1975 & 730.5 & & \end{array}$

2 Pumpage for January through September. 
TABLE 3.--Pumpage from the Potomac Formation in New Castle County--Continued

Getty

PRODUCTION WELLS: Dc41-4, Dc42-6, Dc51-7, Dc52-24, Eb15-4, Eb15-5, Ec12-20, Ec13-6, Ec14-7, and Ec22-3.

$\begin{array}{lccccc}\text { YEAR } & \text { PUMPAGE } & \text { YEAR } & \text { PUMPAGE } & \text { YEAR } & \text { PUMPAGE } \\ 1955 & 110.0 & 1964 & 903.6 & 1973 & 1430.6 \\ 1956 & 644.3 & 1965 & 798.4 & 1974 & 1216.9 \\ 1957 & 1203.7 & 1966 & 913.0 & 1975 & 1341.9 \\ 1958 & 1307.7 & 1967 & 778.0 & 1976 & 1434.9 \\ 1959 & 1345.5 & 1968 & 841.6 & 1977 & 1499.5 \\ 1960 & 1256.9 & 1969 & 933.4 & 1978 & 1280.6 \\ 1961 & 1247.4 & 1970 & 1067.3 & 1979 & 1413.9 \\ 1962 & 1210.1 & 1971 & 1028.6 & 1980 & 1468.9 \\ 1963 & 1028.6 & 1972 & 1058.7 & & \end{array}$

Glendale

PRODUCTION WELLS: Dc31-10, Dc31-21, Dc31-24, and Pleistocene wells.

$\begin{array}{cccccc}\text { YEAR } & \text { PUMPAGE } & \text { YEAR } & \text { PUMPAGE } & \text { YEAR } & \text { PUMPAGE } \\ 1973 & 433.7 & 1976 & 669.1 & 1979 & 630.9 \\ 1974 & 776.1 & 1977 & 600.6 & 1980 & 696.2 \\ 1975 & 647.4 & 1978 & 560.0 & & \end{array}$

$\underline{\text { ICI }}$

PRODUCTION WELL: Cd44-14.

$\begin{array}{lccccc}\text { YEAR } & \text { PUMPAGE } & \text { YEAR } & \text { PUMPAGE } & \text { YEAR } & \text { PUMPAGE } \\ 1973 & 119.4 & 1976 & 147.6 & 1979 & 147.2 \\ 1974 & 147.5 & 1977 & 136.8 & 1980 & 120.7 \\ 1975 & 156.2 & 1978 & 151.3 & & \end{array}$

\section{Jefferson Farms}

PRODUCTION WELLS: Cd51-13, Cd51-14, and Cd51-15.

$\begin{array}{lccccc}\text { YEAR } & \text { PUMPAGE } & \text { YEAR } & \text { PUMPAGE } & \text { YEAR } & \text { PUMPAGE } \\ 1962 & 191.4 & 1969 & 191.0 & 1976 & 164.7 \\ 1963 & 178.0 & 1970 & 265.0 & 1977 & 277.0 \\ 1964 & 314.7 & 1971 & 240.0 & 1978 & 261.8 \\ 1965 & 326.4 & 1972 & 257.2 & 1979 & 245.2 \\ 1966 & 179.8 & 1973 & 238.0 & 1980 & 272.2 \\ 1967 & 165.7 & 1974 & 345.1 & & \\ 1968 & 183.4 & 1975 & 275.2 & & \end{array}$


TABLE 3.--Pumpage from the Potomac Formation in New Castle County--Continued

Llangollen Estates

PRODUCTION WELLS: Dc23-2, Dc23-9, Dc23-10, Dc23-12, Dc24-1, Dc24-14, Dc24-15, Dc24-17, Dc24-18, Dc24-19, Dc24-40, and Dc24-41.

$\begin{array}{lccccc}\text { YEAR } & \text { PUMPAGE } & \text { YEAR } & \text { PUMPAGE } & \text { YEAR } & \text { PUMPAGE } \\ 1955 & 406.8 & 1964 & 578.4 & 1973 & 923.5 \\ 1956 & - & 1965 & 565.1 & 1974 & 543.7 \\ 1957 & 523.0 & 1966 & 591.8 & 1975 & 579.8 \\ 1958 & 476.5 & 1967 & 495.2 & 1976 & 626.9 \\ 1959 & 566.4 & 1968 & 601.1 & 1977 & 679.2 \\ 1960 & 603.4 & 1969 & 634.6 & 1978 & 699.0 \\ 1961 & 516.9 & 1970 & 925.9 & 1979 & 648.5 \\ 1962 & 606.9 & 1971 & 950.5 & 1980 & 670.6 \\ 1963 & 524.1 & 1972 & 1205.9 & & \end{array}$

\section{Midvale}

PRODUCTION WELLS: Dc14-3, Dc14-53, and Dc14-54.

$\begin{array}{lccccc}\text { YEAR } & \text { PUMPAGE } & \text { YEAR } & \text { PUMPAGE } & \text { YEAR } & \text { PUMPAGE } \\ 1955 & 172.3 & 1964 & 180.5 & 1973 & 73.9 \\ 1956 & - & 1965 & 207.3 & 1974 & 158.0 \\ 1957 & 189.0 & 1966 & 151.0 & 1975 & 162.1 \\ 1958 & 179.8 & 1967 & 159.0 & 1976 & 136.1 \\ 1959 & 127.2 & 1968 & 149.2 & 1977 & 148.3 \\ 1960 & 95.0 & 1969 & 170.3 & 1978 & 146.9 \\ 1961 & 282.3 & 1970 & 140.2 & 1979 & 144.1 \\ 1962 & 216.6 & 1971 & 125.2 & 1980 & 137.5 \\ 1963 & 152.9 & 1972 & 34.5 & & \end{array}$

\section{Newark}

PRODUCTION WELLS: Ca55-3, Ca55-4, Ca55-5, Ca55-7, Db11-49, Db12-27, $\mathrm{Db} 22-42$, and $\mathrm{Db} 32-16$.

$\begin{array}{lccccc}\text { YEAR } & \text { PUMPAGE } & \text { YEAR } & \text { PUMPAGE } & \text { YEAR } & \text { PUMPAGE } \\ 1975 & 388.1 & 1977 & 434.9 & 1979 & 466.7 \\ 1976 & 446.5 & 1978 & 446.1 & 1980 & 348.1^{3}\end{array}$

New Castle

PRODUCTION WELLS: Cc55-17, Cd51-8, Cd52-13, Cd52-27, and Dc15-16.

$\begin{array}{lccccc}\text { YEAR } & \text { PUMPAGE } & \text { YEAR } & \text { PUMPAGE } & \text { YEAR } & \text { PUMPAGE } \\ 1952 & 15.0 & 1962 & 167.2 & 1972 & 166.2 \\ 1953 & 24.1 & 1963 & 169.3 & 1973 & 164.7 \\ 1954 & - & 1964 & 173.3 & 1974 & 173.1 \\ 1955 & 104.3 & 1965 & 174.9 & 1975 & 150.3 \\ 1956 & 70.2 & 1966 & 164.6 & 1976 & 261.1 \\ 1957 & 93.9 & 1967 & 171.2 & 1977 & 192.1 \\ 1958 & 71.9 & 1968 & 173.6 & 1978 & 225.9 \\ 1959 & 58.5 & 1969 & 184.9 & 1979 & 226.1 \\ 1960 & 52.2 & 1970 & 197.9 & 1980 & 213.3 \\ 1961 & 141.5 & 1971 & 164.8 & & \end{array}$

3 Pumpage for January through September. 
TABLE 3.--Pumpage from the Potomac Formation in New Castle County--Continued

Tuxedo Park

PRODUCTION WELLS: Various."

$\begin{array}{lccccc}\text { YEAR } & \text { PUMPAGE } & \text { YEAR } & \text { PUMPAGE } & \text { YEAR } & \text { PUMPAGE } \\ 1955 & 93.3 & 1962 & 214.0 & 1969 & 134.3 \\ 1956 & - & 1963 & 209.3 & 1970 & 134.4 \\ 1957 & 103.8 & 1964 & 174.6 & 1971 & 13.0 \\ 1958 & 121.1 & 1965 & 130.9 & 1972 & 6.83 \\ 1959 & 203.5 & 1966 & 120.4 & 1973 & 5.44 \\ 1960 & 240.4 & 1967 & 124.1 & 1974 & 2.78 \\ 1961 & 210.7 & 1968 & 132.3 & 1975 & 2.42\end{array}$

\section{Wilmington Airport}

PRODUCTION WELLS: Cc45-1, Cc45-2, and Cc55-1.

$\begin{array}{lccccc}\text { YEAR } & \text { PUMPAGE } & \text { YEAR } & \text { PUMPAGE } & \text { YEAR } & \text { PUMPAGE } \\ 1946 & 18.5 & 1952 & 95.0 & 1976 & 122.3 \\ 1947 & 49.6 & 1953 & 102.3 & 1977 & 69.1 \\ 1948 & 63.7 & 1954 & 100.8 & 1978 & 115.1 \\ 1949 & 48.5 & 1955 & 99.7 & 1979 & 90.7 \\ 1950 & 40.3 & 1956 & 112.2 & 1980 & 91.3 \\ 1951 & 73.7 & 1957 & 112.2 & & \end{array}$

Wilmington Manor

PRODUCTION WELLS: Cc55-6 and Cc55-7.

$\begin{array}{lccccc}\text { YEAR } & \text { PUMPAGE } & \text { YEAR } & \text { PUMPAGE } & \text { YEAR } & \text { PUMPAGE } \\ 1955 & 5.83 & 1961 & 6.92 & 1967 & 3.49 \\ 1956 & - & 1962 & 7.29 & 1968 & 7.90 \\ 1957 & 7.98 & 1963 & 4.93 & 1969 & 1.07 \\ 1958 & 8.58 & 1964 & 5.63 & 1970 & 2.60 \\ 1959 & 2.38 & 1965 & 3.69 & 1971 & 11.63 \\ 1960 & 3.56 & 1966 & 6.88 & & \end{array}$

Wilmington Manor Gardens

PRODUCTION WELLS: Cd51-1, Cd51-11, and Cd51-12.

$\begin{array}{lccccc}\text { YEAR } & \text { PUMPAGE } & \text { YEAR } & \text { PUMPAGE } & \text { YEAR } & \text { PUMPAGE } \\ 1955 & 171.2 & 1964 & 204.1 & 1973 & 205.5 \\ 1956 & - & 1965 & 181.8 & 1974 & 155.2 \\ 1957 & 291.4 & 1966 & 199.6 & 1975 & 251.5 \\ 1958 & 352.2 & 1967 & 188.9 & 1976 & 215.8 \\ 1959 & 307.3 & 1968 & 213.9 & 1977 & 234.5 \\ 1960 & 290.2 & 1969 & 193.6 & 1978 & 231.8 \\ 1961 & 263.5 & 1970 & 215.1 & 1979 & 235.4 \\ 1962 & 250.5 & 1971 & 197.4 & 1980 & 220.7 \\ 1963 & 216.4 & 1972 & 139.5 & & \end{array}$

4 Incomplete well records. 
Areas not included in table 3, because of insufficient data, include Delaware City, Delaware State Hospital, and the towns of Middletown and Newport. Pumpage in these areas is considered minor. Pumpage at Artisans Village began in November 1980 at an average rate of 37 Mgal per month.

Many well fields are in subcrop areas of Potomac sands. In the subcrop area, Pleistocene sediments directly overlie Potomac sands, or the intervening confining bed is relatively thin or discontinuous. Production wells screened in Potomac sands in these areas may withdraw water from Pleistocene sediments, and production wells screened in Pleistocene sediments may withdraw water from the Potomac Formation. Areas included in table 3 with Potomac production wells that may be hydraulically connected with the Pleistocene sediments, include: Army Creek landfill, Castle Hills, du Pont-Newport, Glendale, Midvale, Newark, New Castle, Newport, Tuxedo Park, Wilmington Manor, and Wilmington Manor Gardens.

Also, the following subcrop areas have or have had Pleistocene production wells: Glendale, ICI (ICI Americas, Inc.), Newark, Midvale, Newport, and Tuxedo Park. In table 3, pumpage valus for only two areas, Glendale and Tuxedo Park, are known to include pumpage from both Pleistocene and Potomac wells.

Records of Potomac Formation wells in table 7 list the screened interval and date drilled. However, because of incomplete well records and questionable thickness of Pleistocene sediments in some areas, both table 3 and the well records may include some Pleistocene wells or exclude some Potomac wells in certain areas. These areas include: Castle Hills, Delaware State Hospital, ICI, Newark, Newport, Tuxedo Park, Wilmington Manor, and Wilmington Manur Gardens. In all the subcrop areas referred to above, the direct hydraulic connection between Potomac and Pleistocene sediments creates a complex problem in determining the amount of pumpage attributable to each formation. Analysis of the local groundwater flow must necessarily include determination of the thickness, extent, and hydraulic conductivity of the confining bed.

Figure 9 is a map showing the location of selected wells in the Potomac Formation, including those production wells for which monthly pumpage data are available. Graphs of monthly pumpage from these wells and total monthly pumpage from entire well fields are shown in figures 10 through 67. Hydrographs of waterlevel fluctuations in wells at each well field are shown for comparison. Pumpage data are shown in millions of gallons per month. Horizontal dashed lines represent average monthly pumpage from wells for which only yearly pumpage data were available. Well-field names are indicated in the upper right corner of each page, and well numbers are indicated in the upper left corner of each graph. Graphs for total monthly pumpage for a well field are indicated by the word "Total" in the upper left corner of the graph. Periods of no record are indicated by a question mark on the graph. Pumpage records for some wells are incomplete for the last 3 months of 1980. This is shown by a vertical dashed line at the end of the bar graph. 


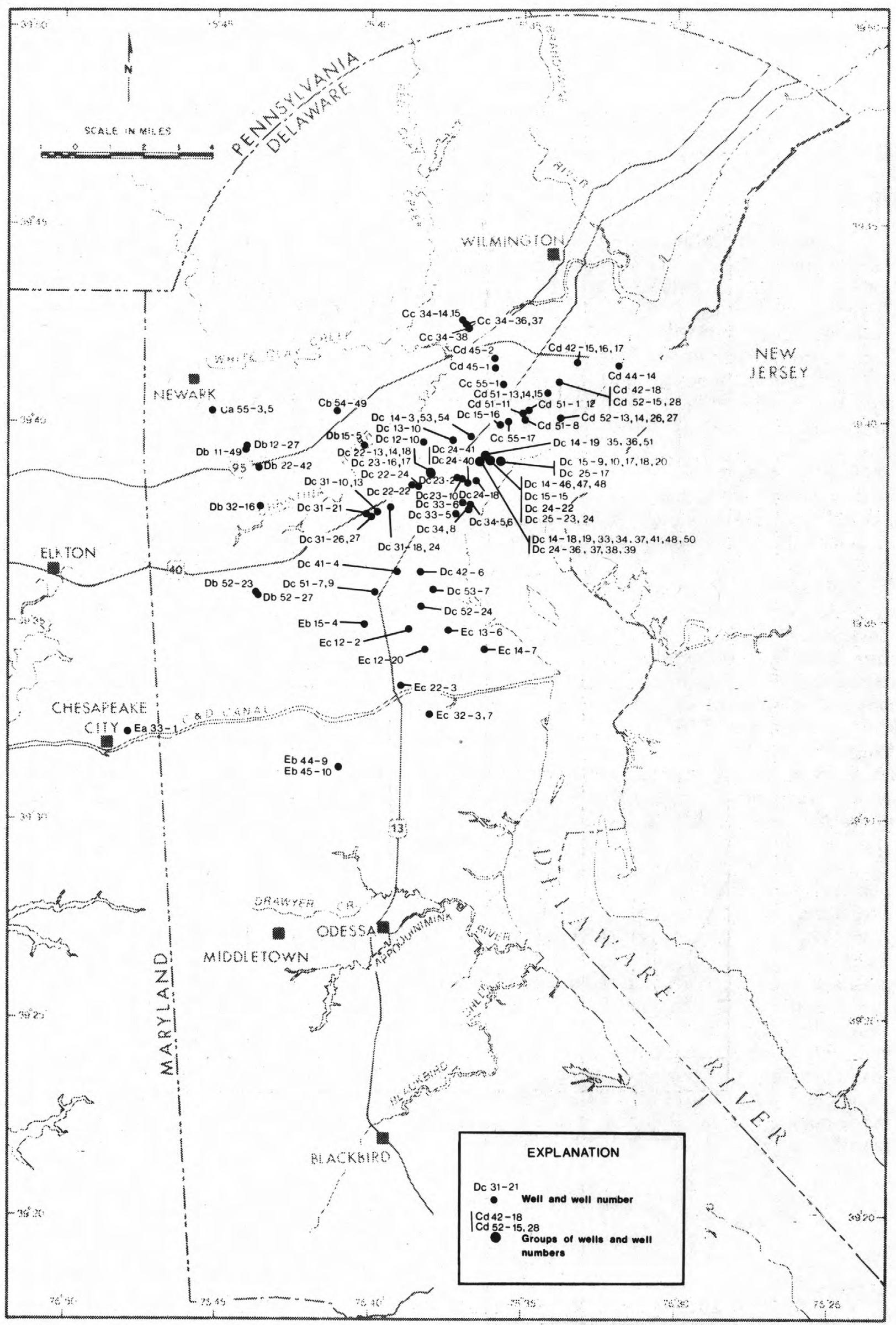

Figure 9.-- Map showing location of selected wells in the Potomac Formation. 
AMOCO
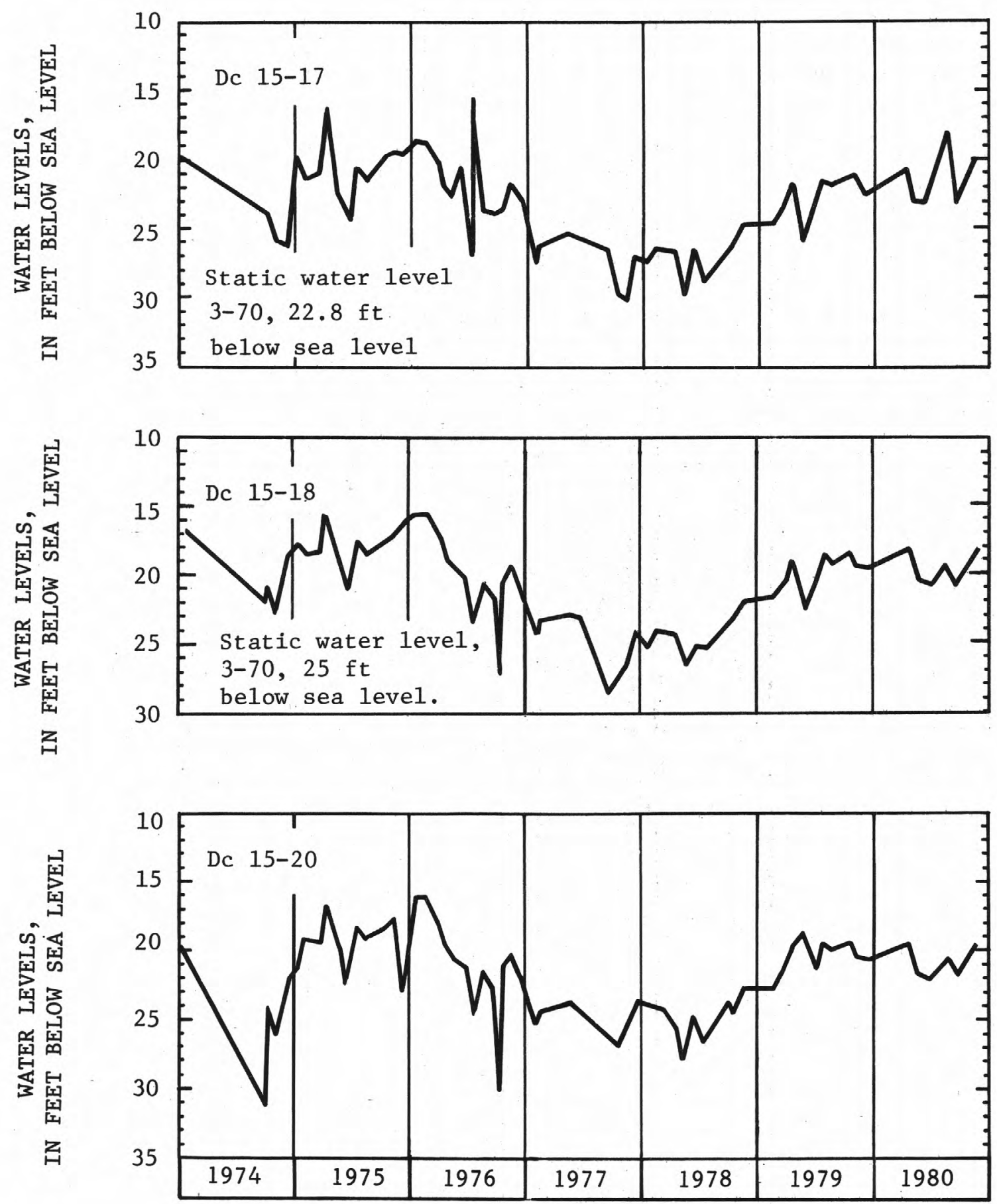

FIGURE 10.--Amoco. Water levels in wells Dc15-17, Dc15-18, and Dc15-20, 1974-80. 
AMOCO
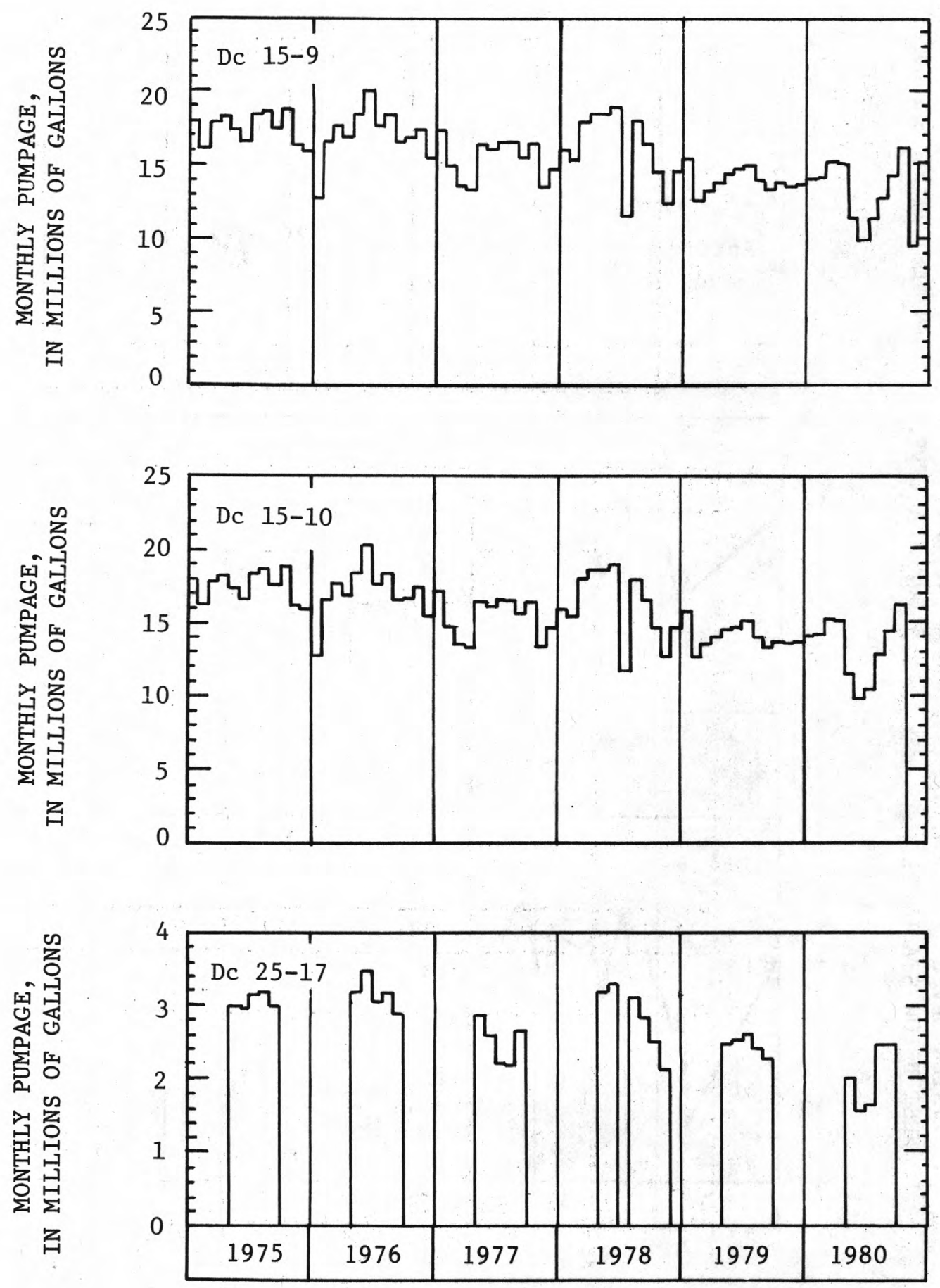

FIGURE 11.--Amoco. Monthly pumpage from Dc15-9, Dc15-10, and Dc25-17, 1975-80. 
AMOCO
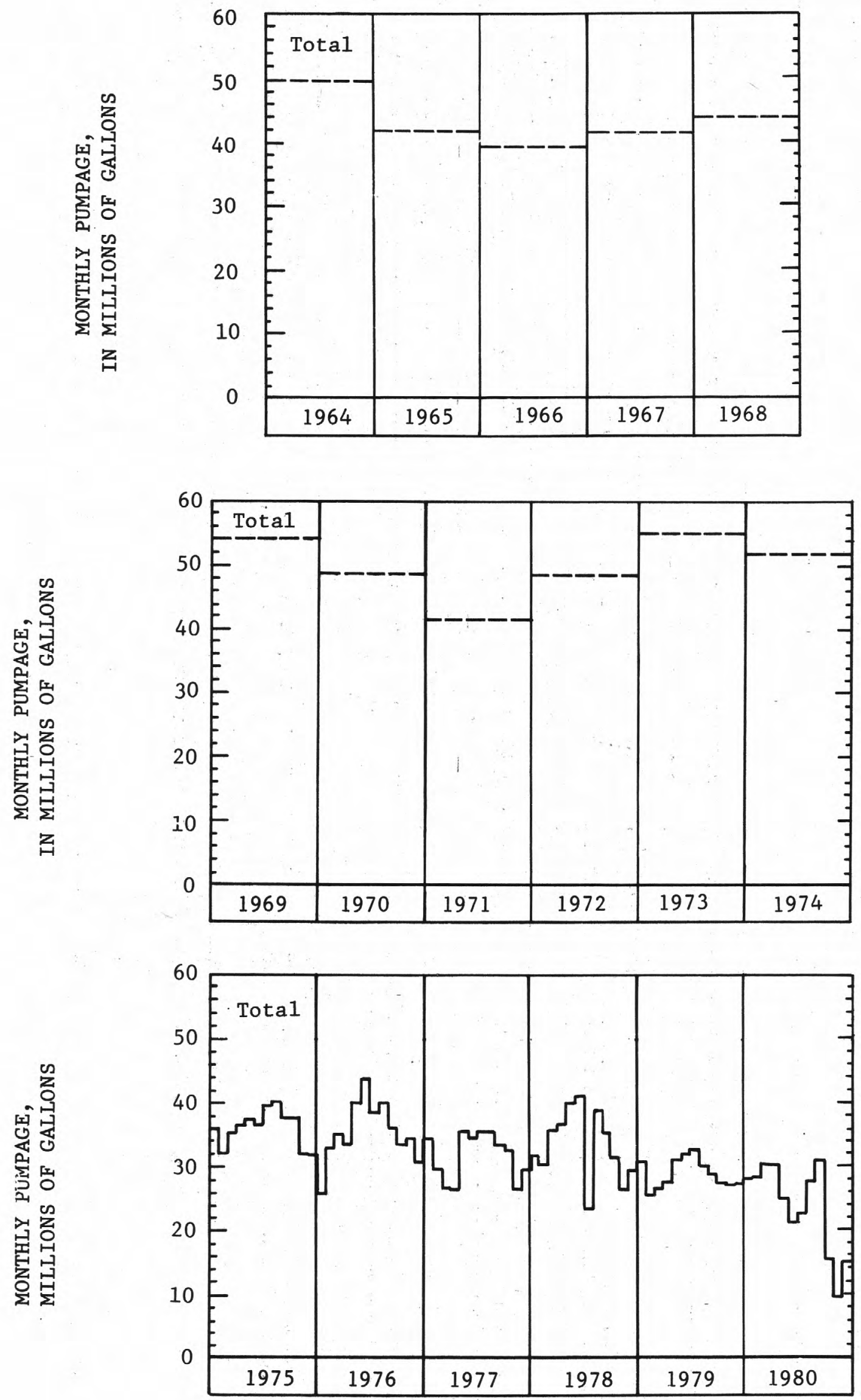

FIGURE 12.--Amoco. Total monthly pumpage from well field, 1964- 80 . 
ARMY CREEK LANDFILL
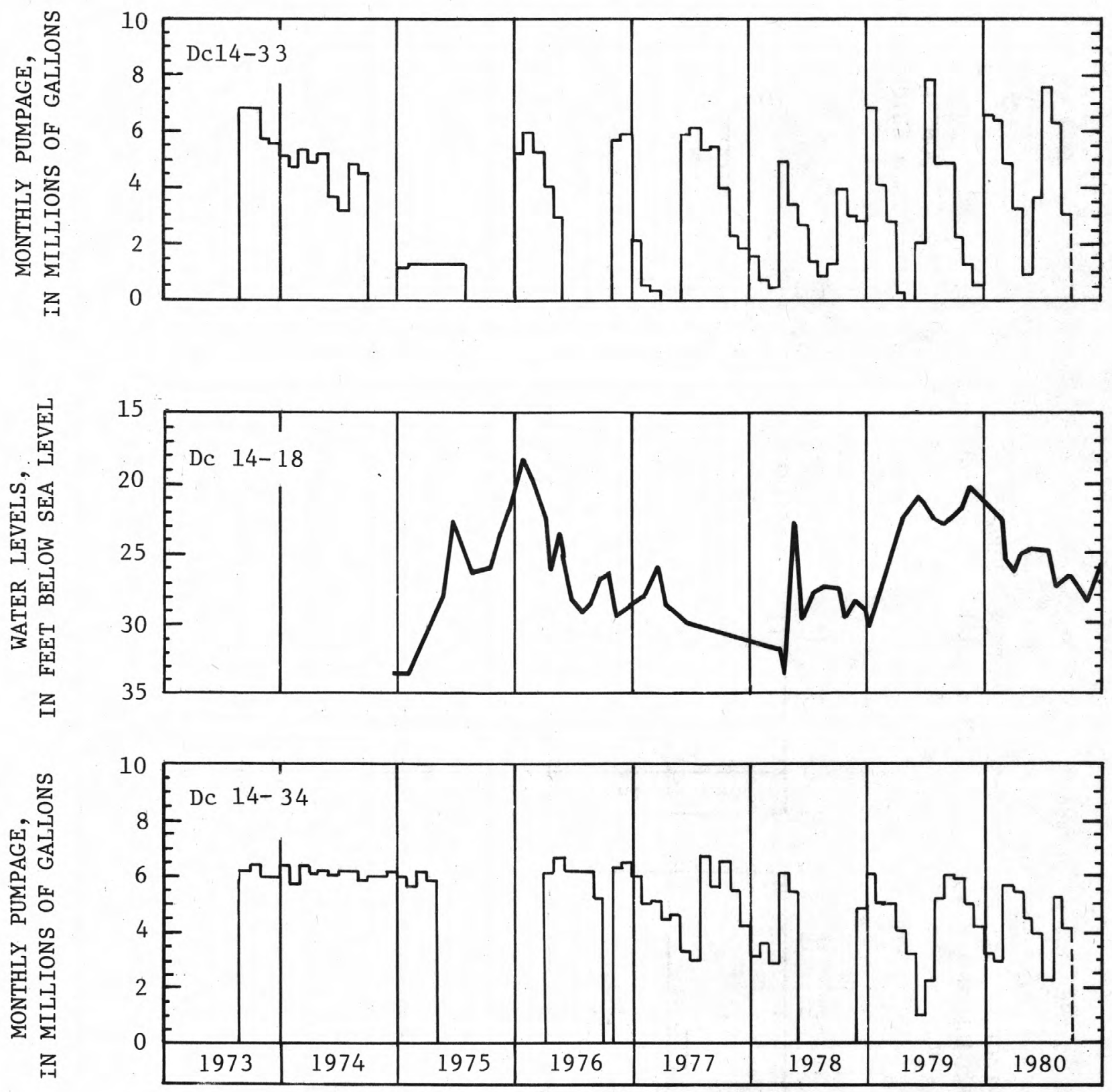

FIGURE 13.--Army creek 1andfil1. Month1y pumpage from Dc14-33 and Dc14-34, 1973-80. Water levels in Dc14-18, 1974-80. 

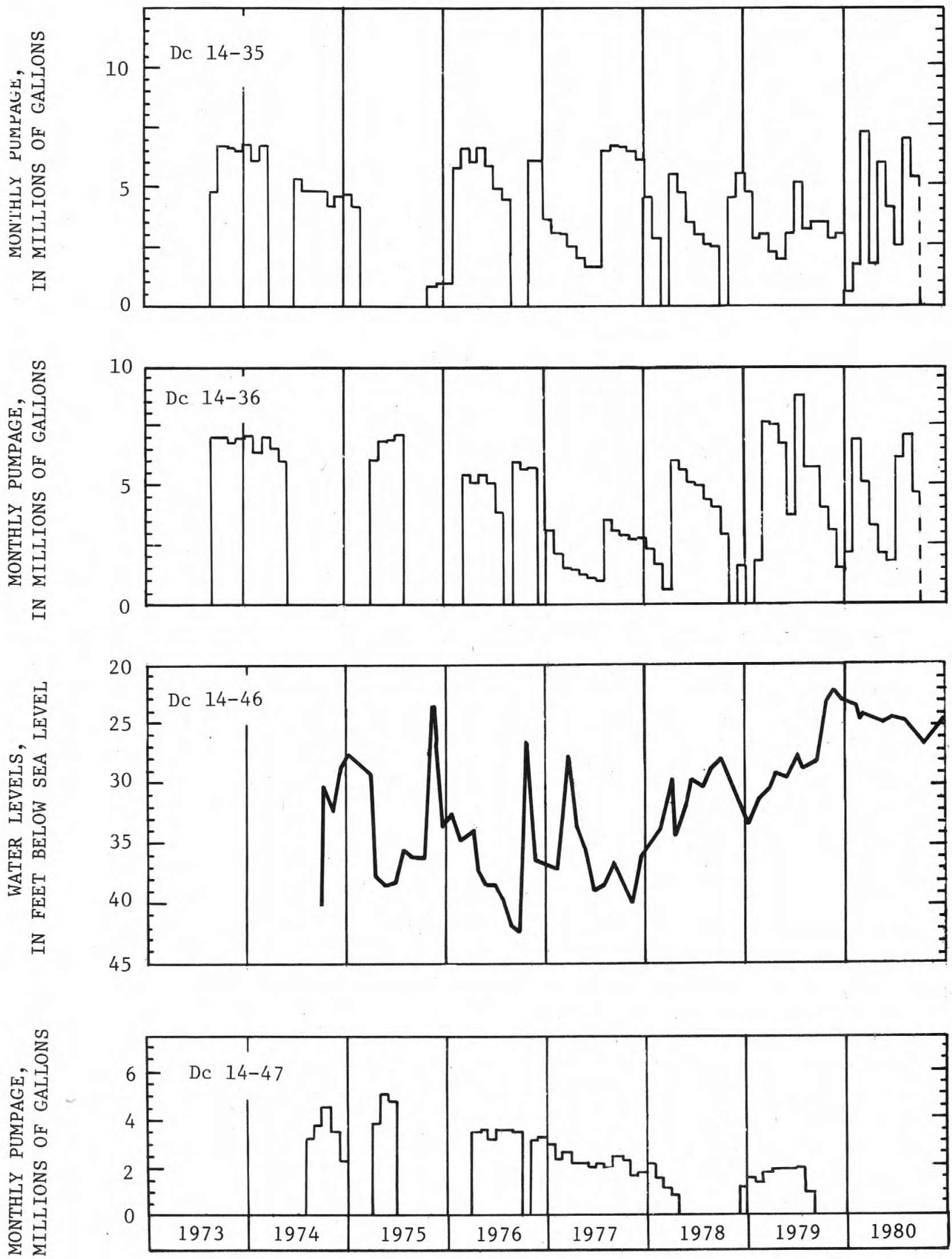

FIGURE 14.--Army Creek landfill. Monthly pumpage from Dc14-35 and Dc14-36, 1973-80, and Dc14-47, 1974- 79 . Water levels in Dc14-46, 1974-80. 
ARMY CREEK LANDFILL
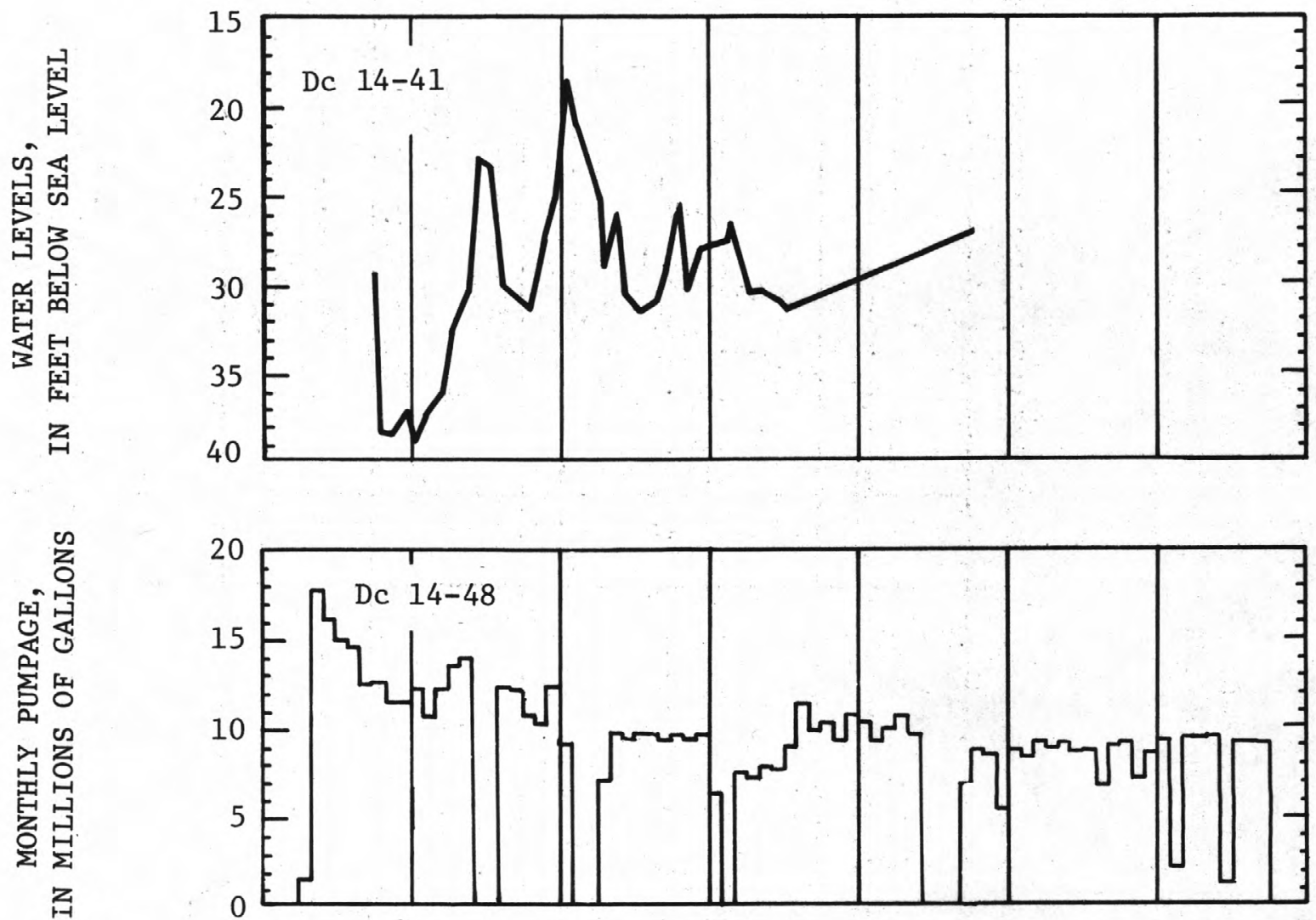

舆

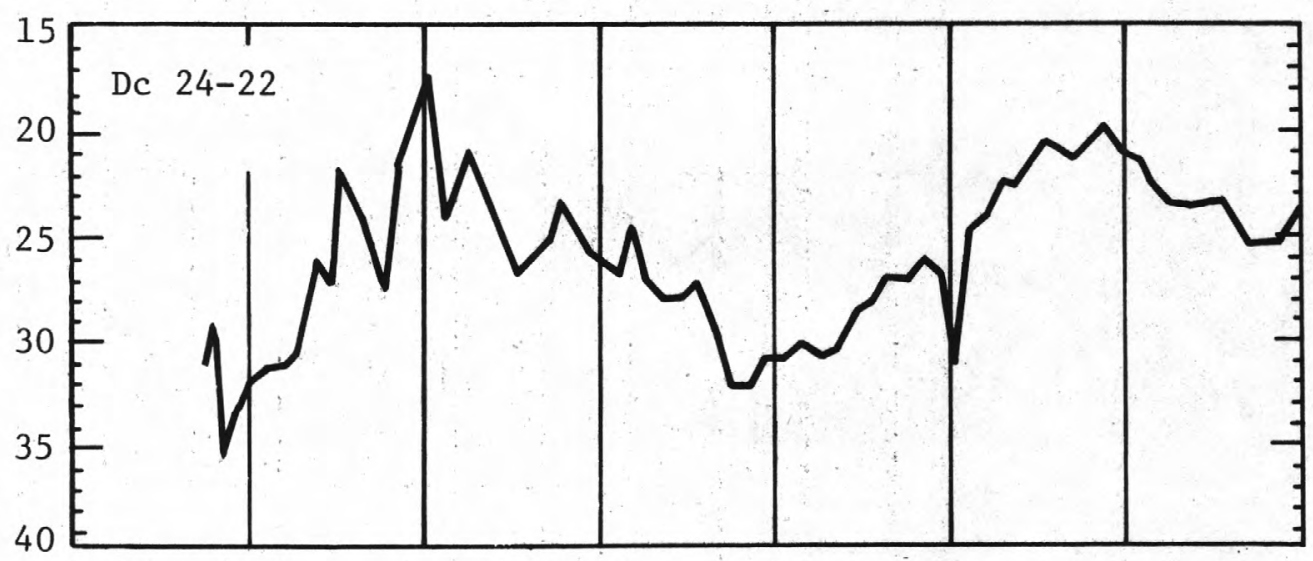

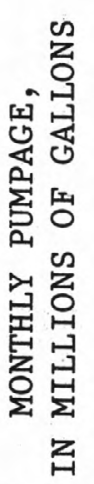

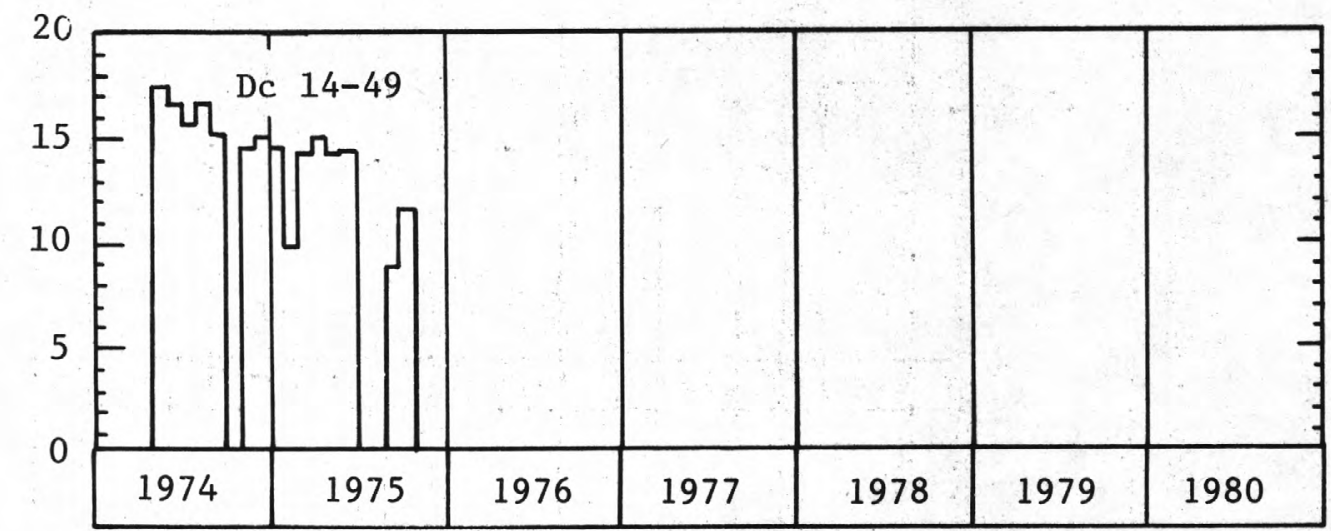

Figure 15.--Army Creek landfill. Monthly pumpage from Dc14-48, 1974-80, and Dc14-49, 1974-75. Water levels in Dc14-41, 1974-78 and Dc24-22, 1974-80. 
ARMY CREEK LANDFILL
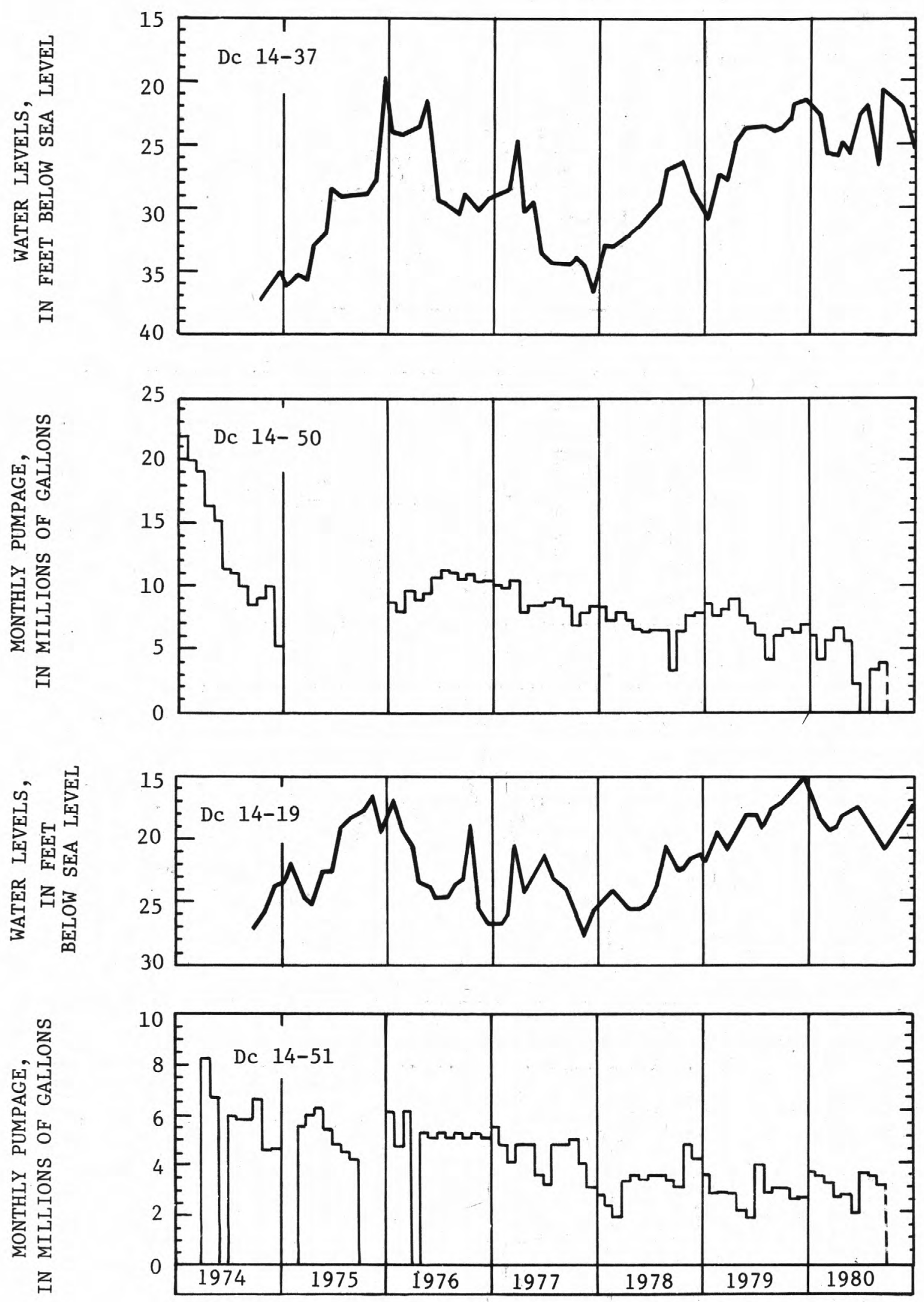

FIGURE 16.--Army Creek 1andfil1. Monthly pumpage in Dc14-50 and Dc14-51, 1974-80. Water levels in Dc14-37 and Dc14-19, 1974-80. 
四

AKMY UHEEK LANURILL

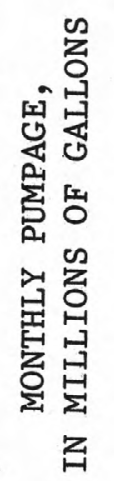

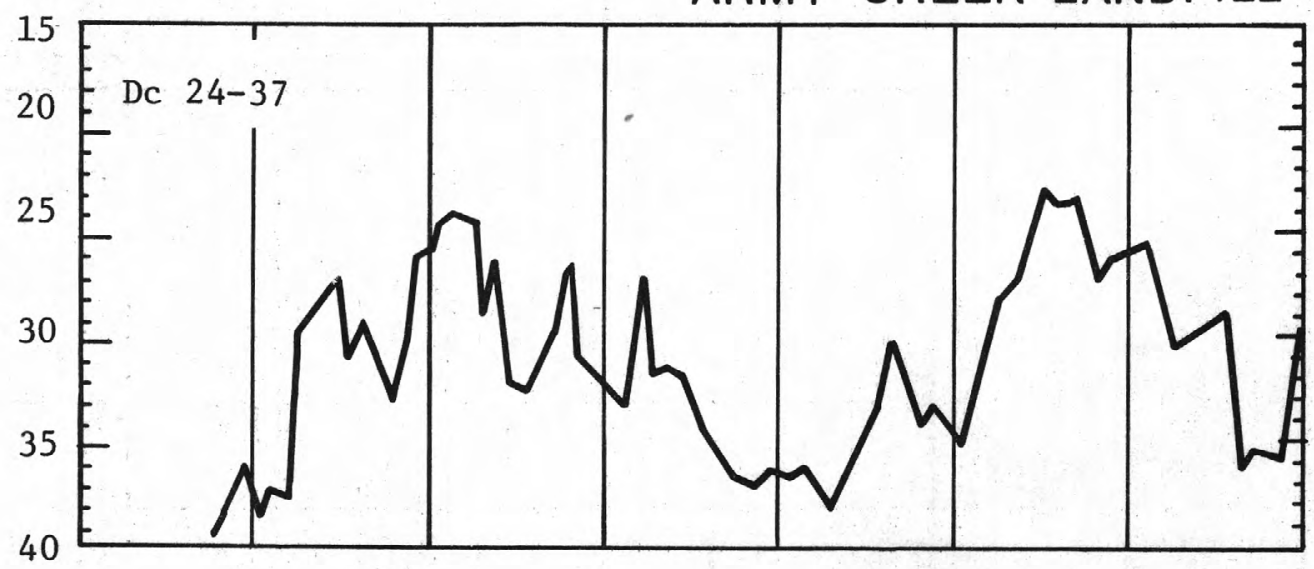

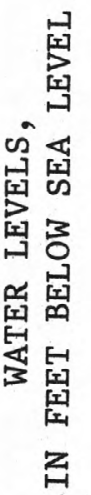
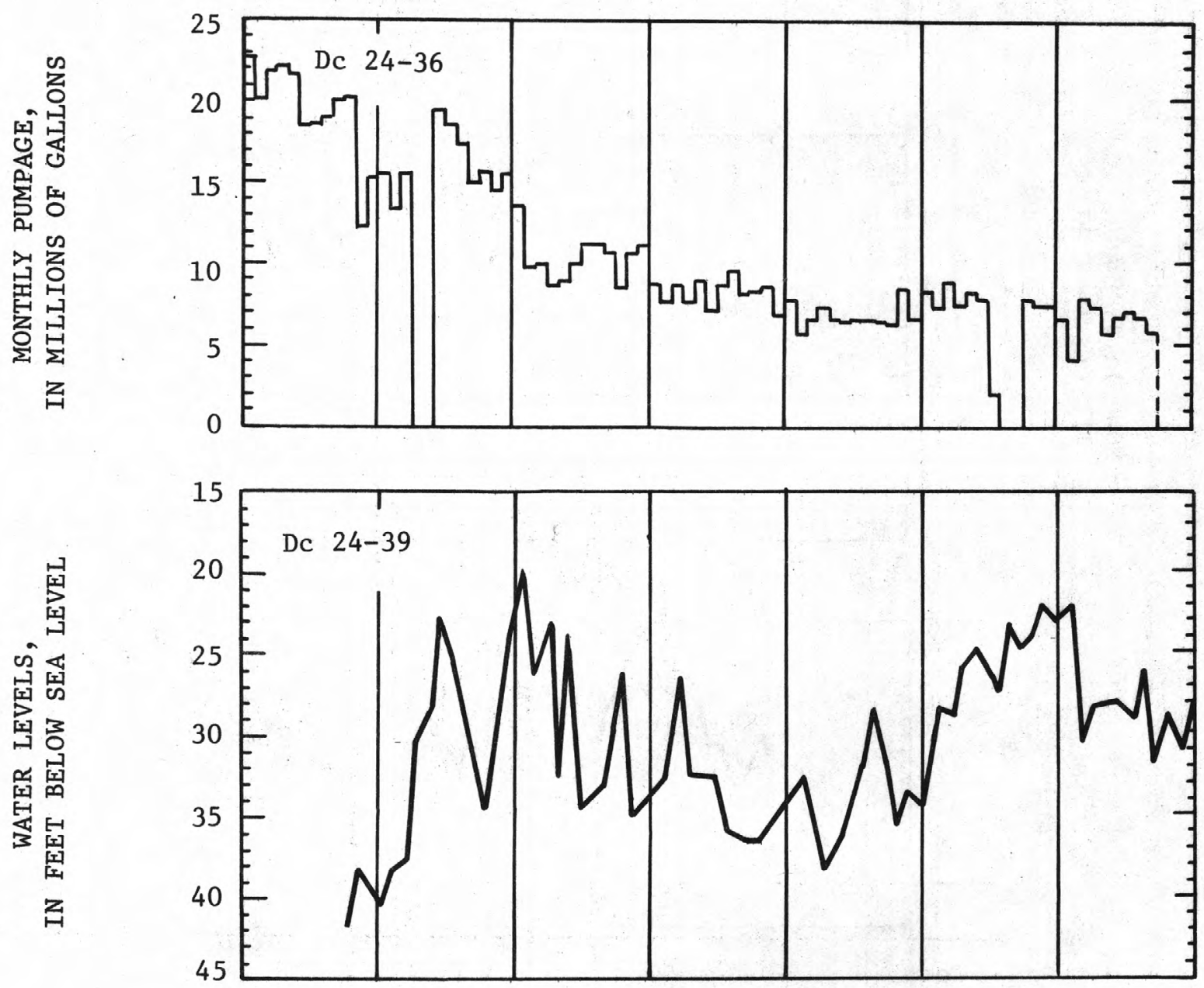

我是

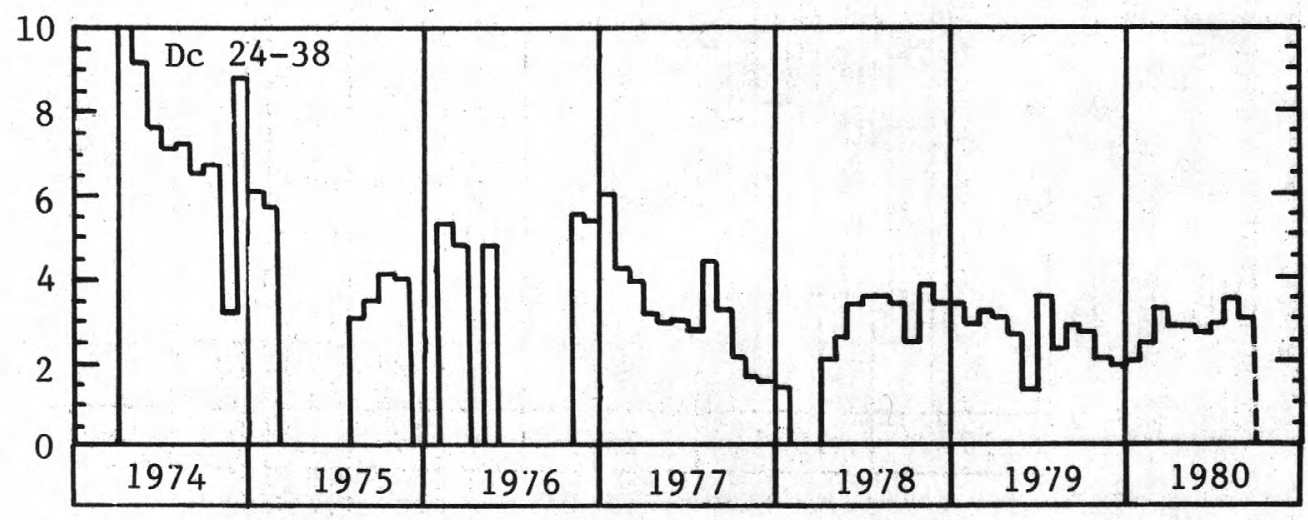

FIGURE 17.--Army Creek landfill. Month1y pumpage in Dc24-36 and Dc24-38, 1974-80. Water levels in Dc24-37 and Dc24-39, 1974-80. 

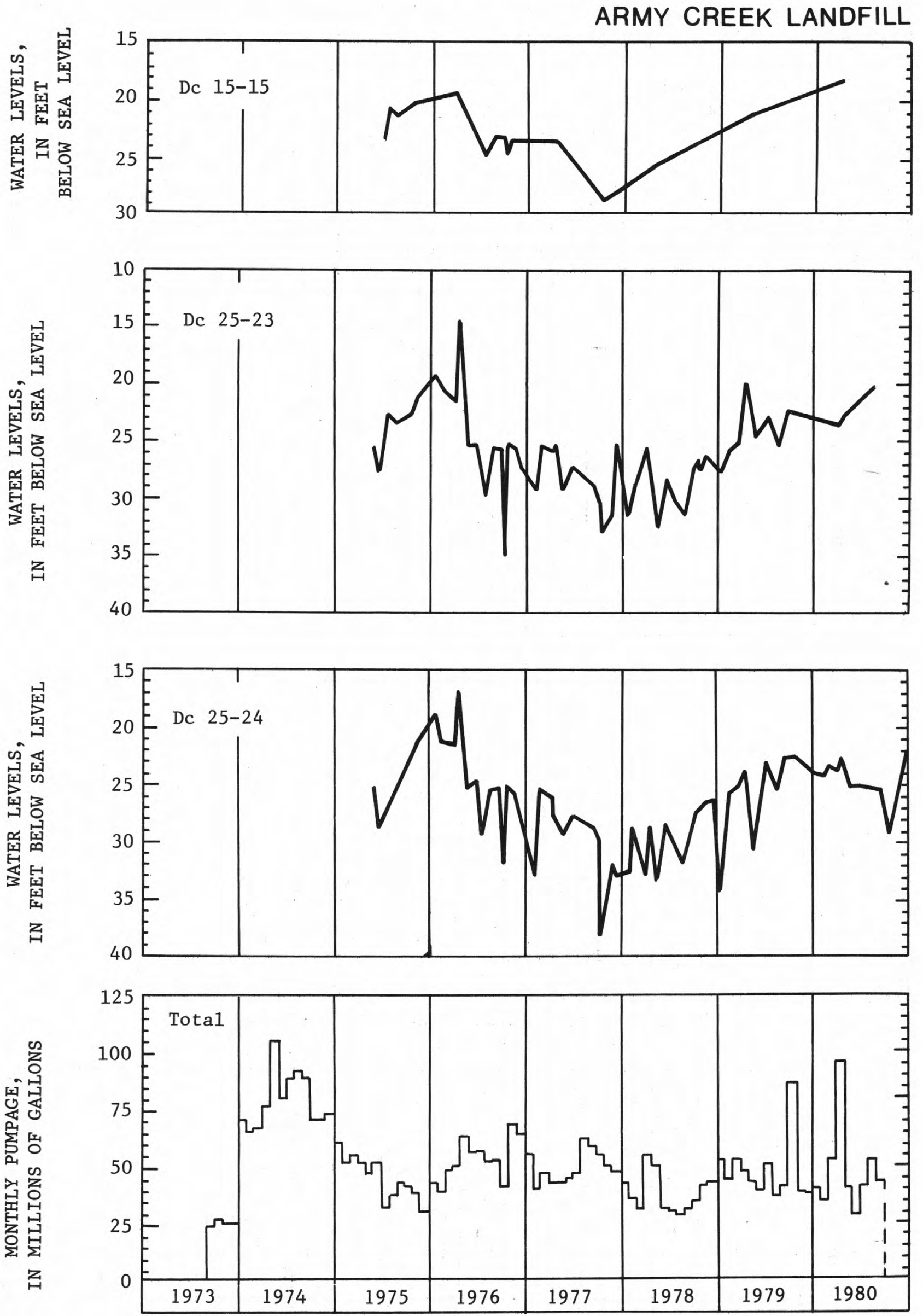

FIGURE 18.--Army Creek landfill. Total monthly pumpage from well field, 1973-80. Water leve1s in Dc15-15, Dc25-2.3, and Dc25-24, 1975-80. 

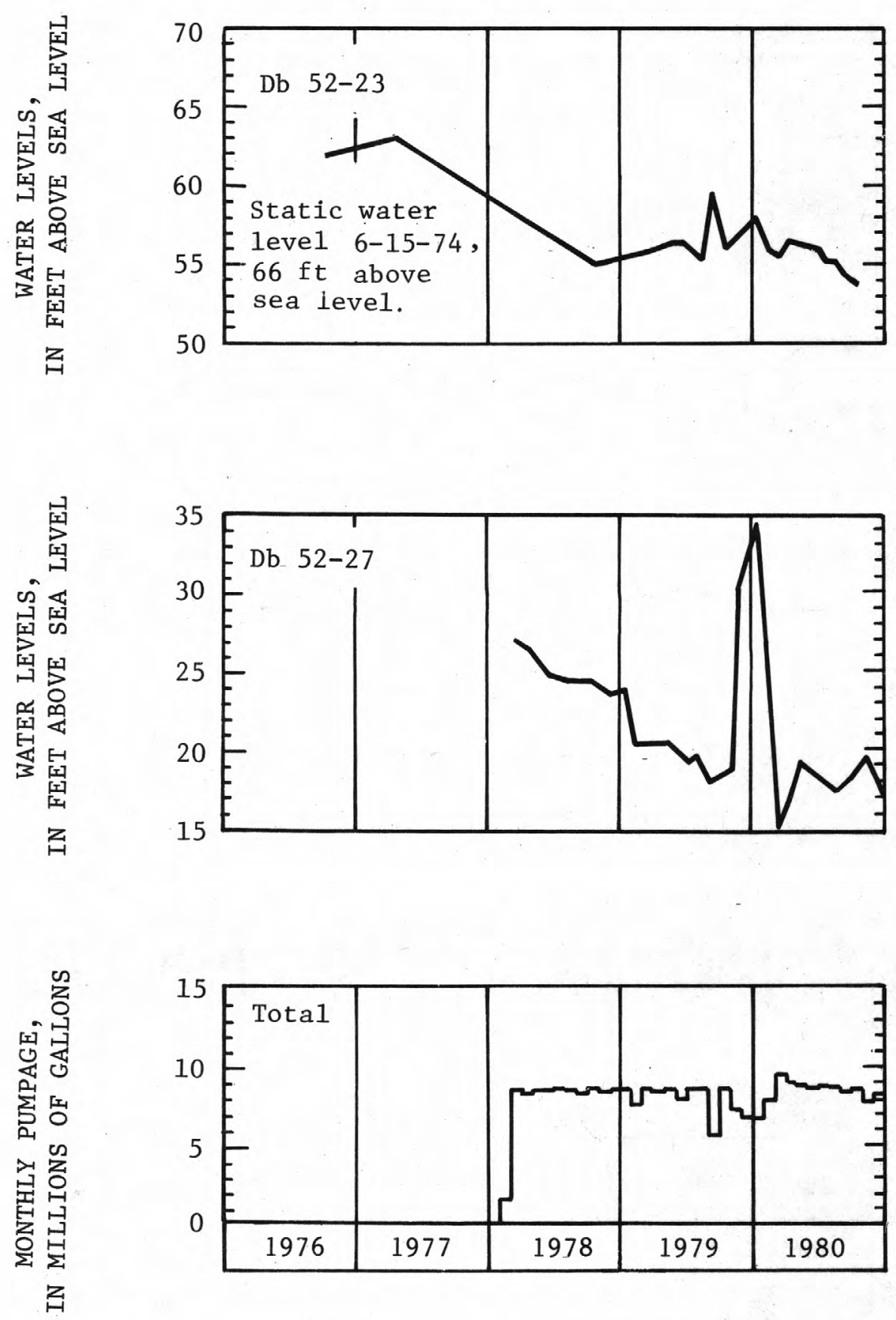

FIGURE 19.--Caravel Farms. Total monthly pumpage from well field, 1978-80. Water levels in Db52-23, 1976-80, and Db52-27, 1978-80. 
CASTLE HILLS
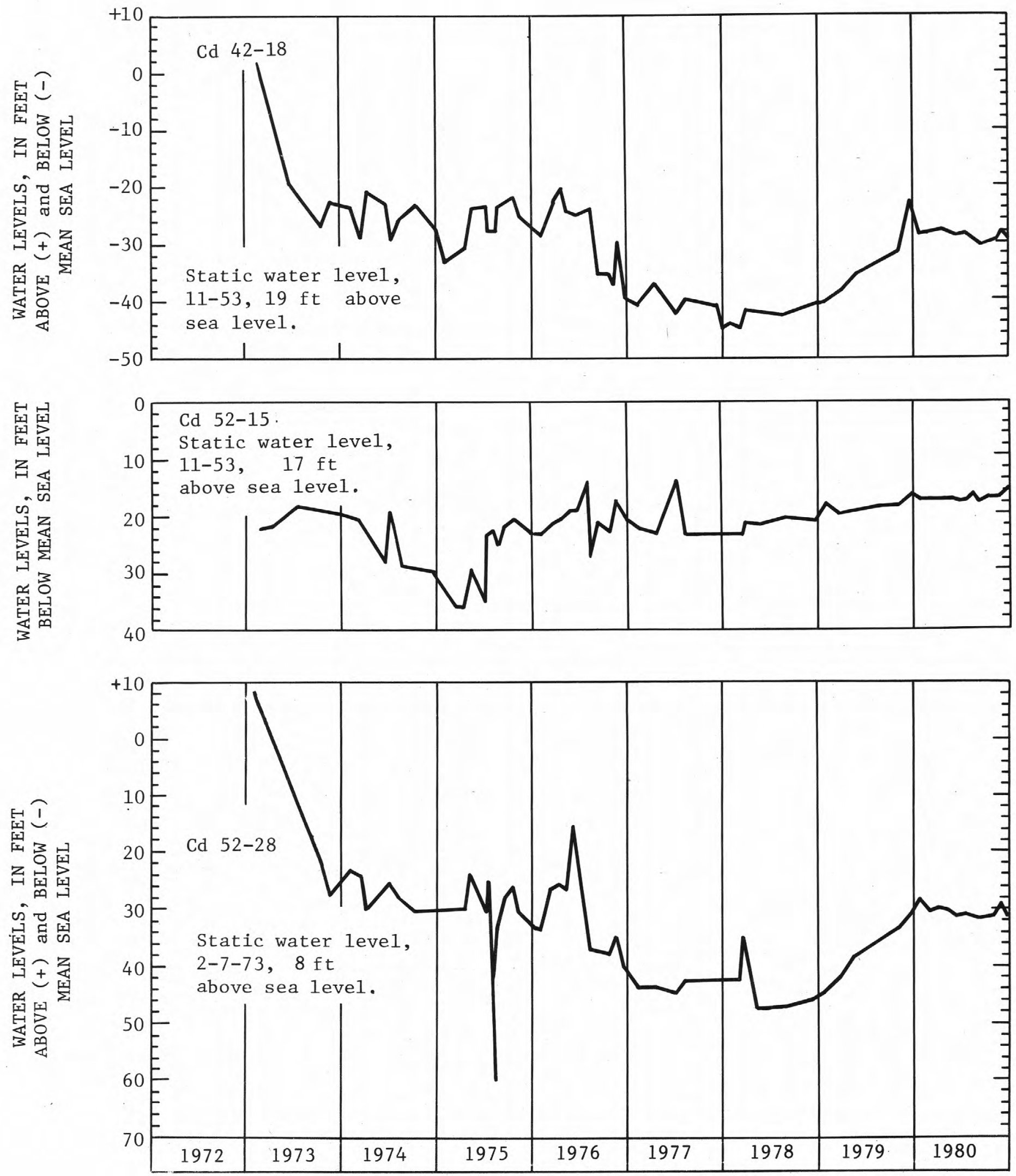

FIGURE 20--Castle Hills. Water levels in Cd42-18, Cd52-15, and, Cd52-28, 1973-80. 
CASTLE HILLS

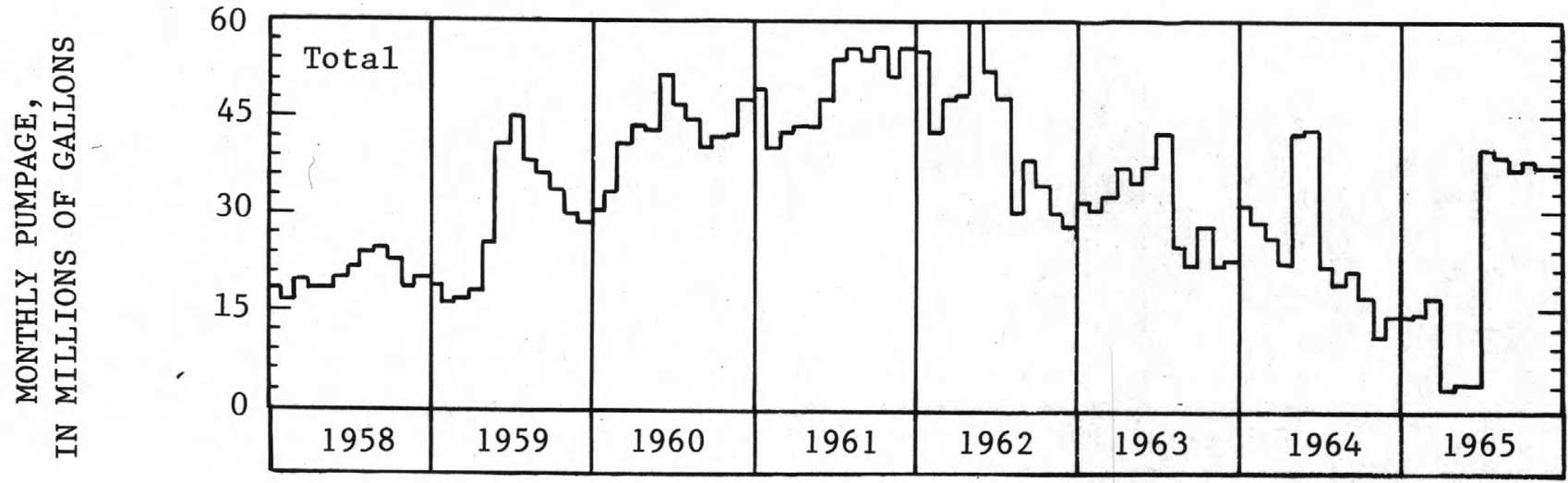

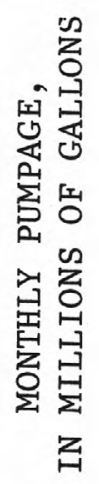

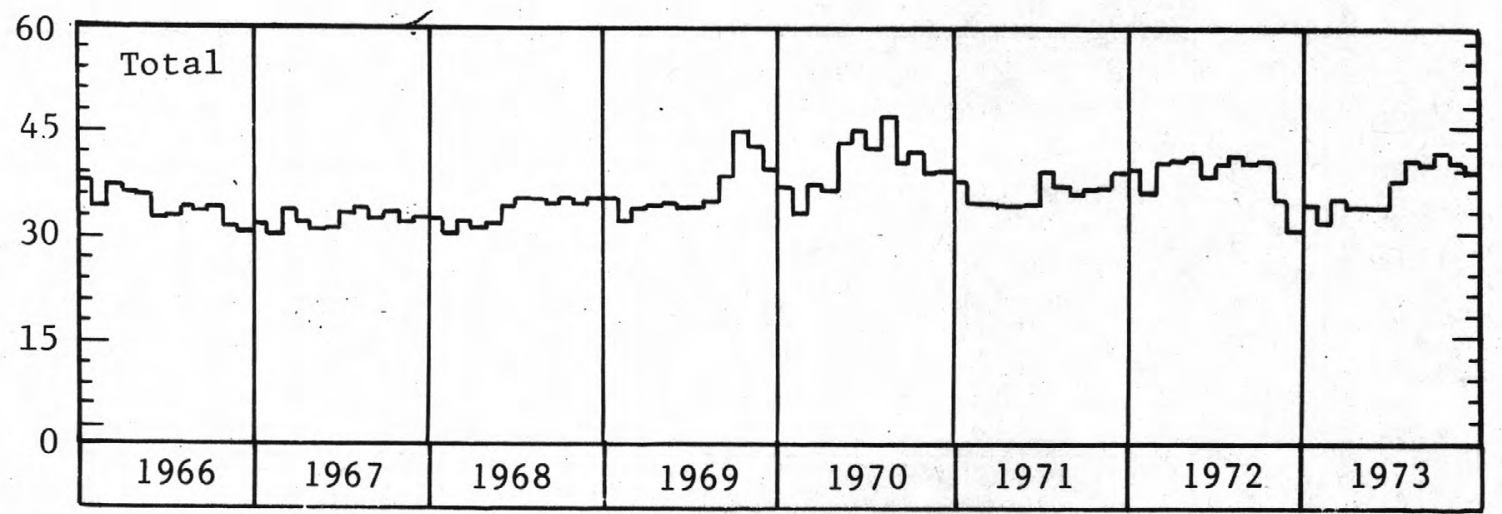

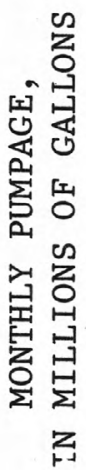

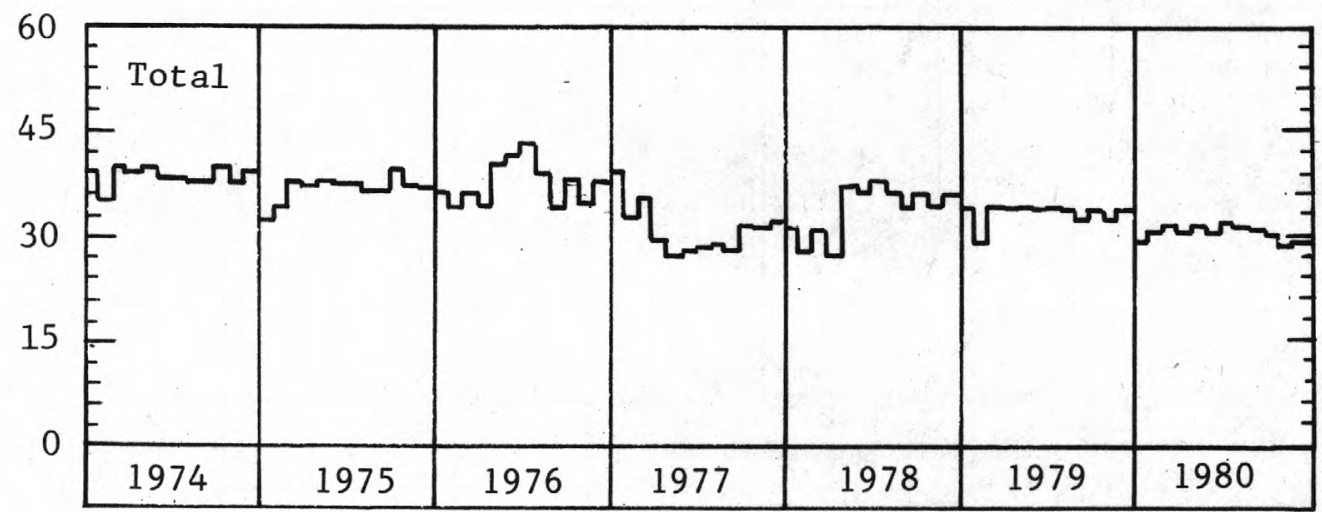

FIGURE 21.--Castle Hills. Total monthly pumpage from well field, 1958-80. 

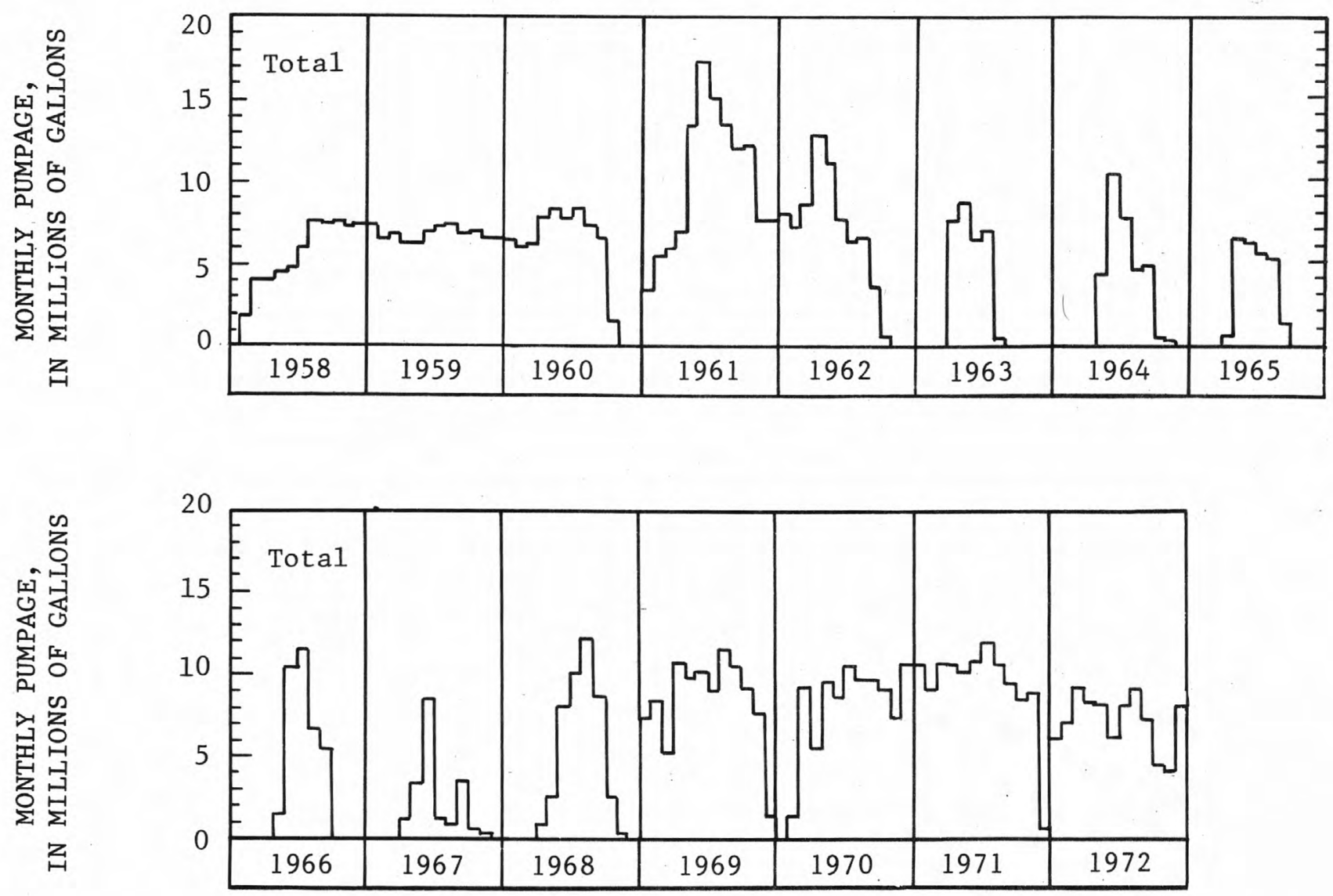

FIGURE 22.--Collins Park. Total month1y pumpage from well field, 1958- 72. 

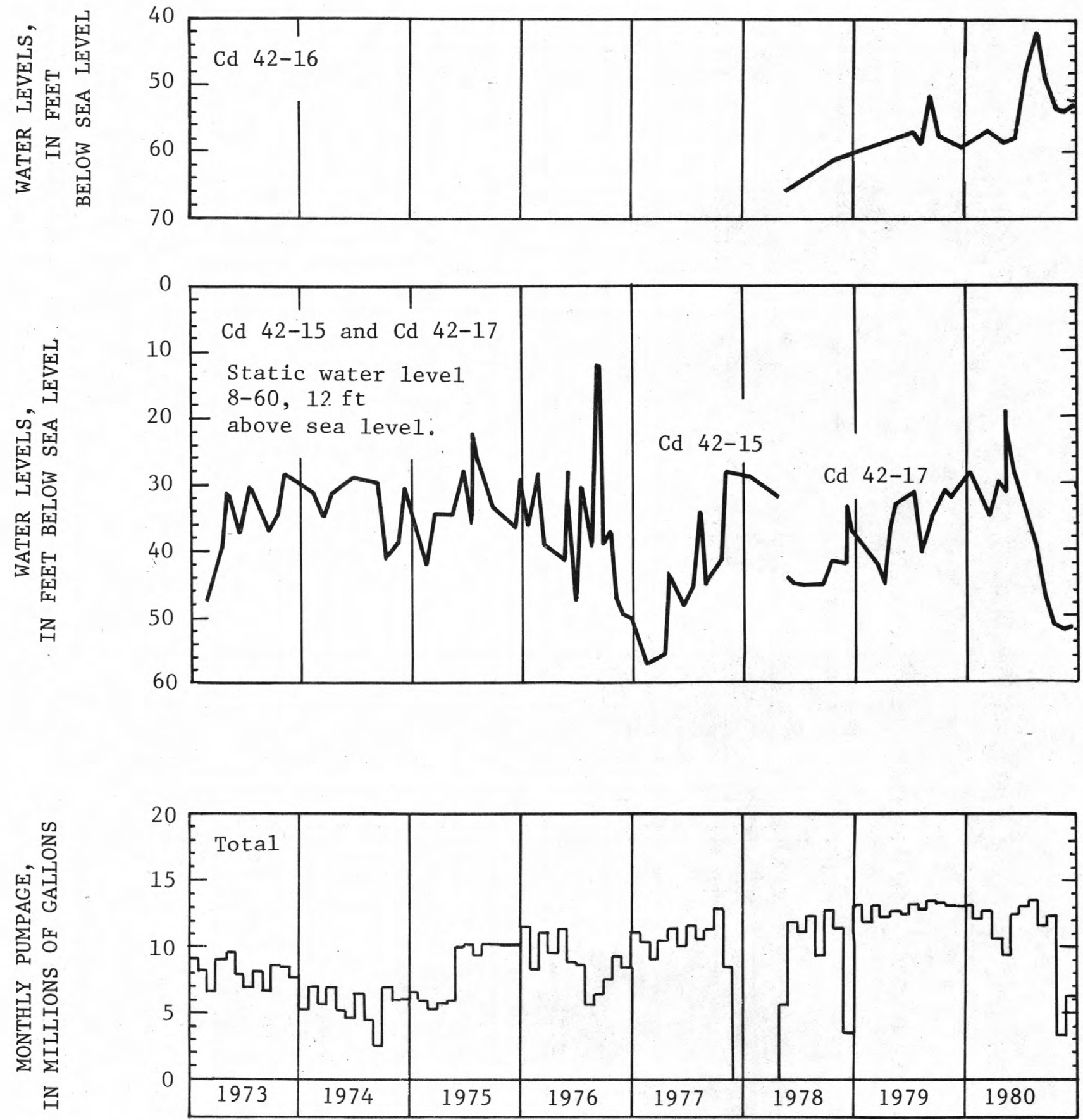

FIGURE 23.--Collins Park. Total monthly pumpage from well field, 1973-80. Water levels in Cd42-16 and Cd42-17, 1978-80, and Cd42-15, 1973-78. 


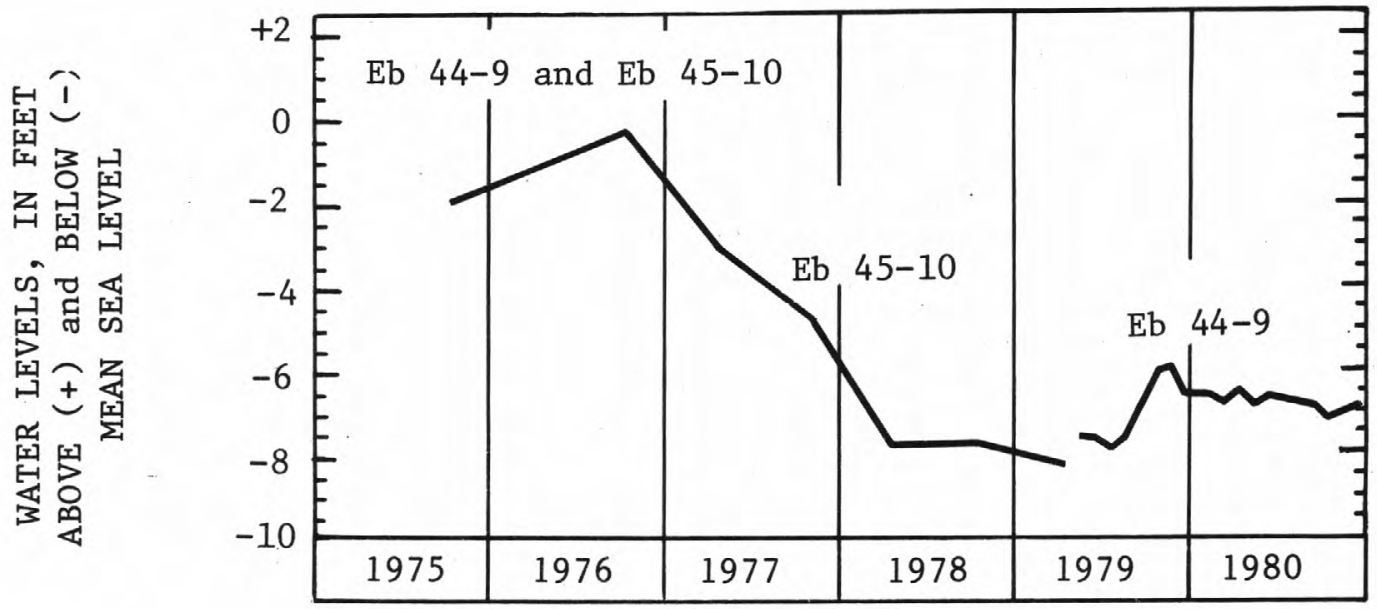

FIGURE 24.--De1marva Power - Summit. Water leve1s in Eb45-10, 1975-79, and Eb44-9, 1979-80.

DU PONT - NEWPORT

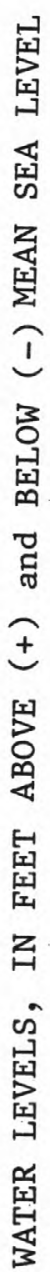
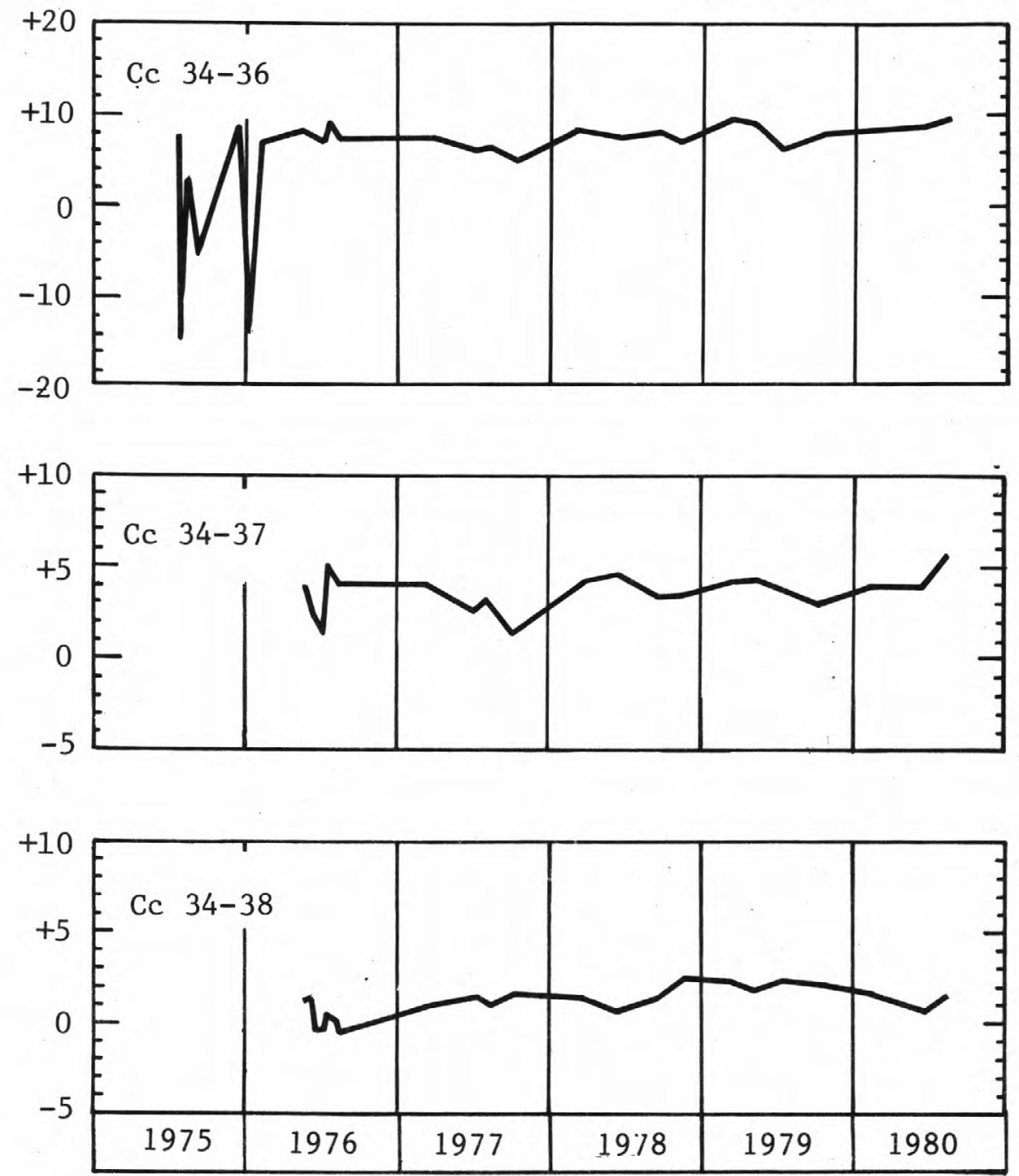

FIGURE 25.--Du Pont - Newport. Water leve1s in Cc34-36, 1975-80, and Cc34-37 and Cc34-38, 1976-80. 


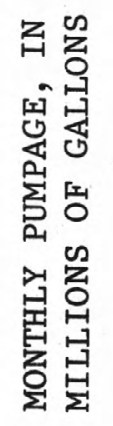

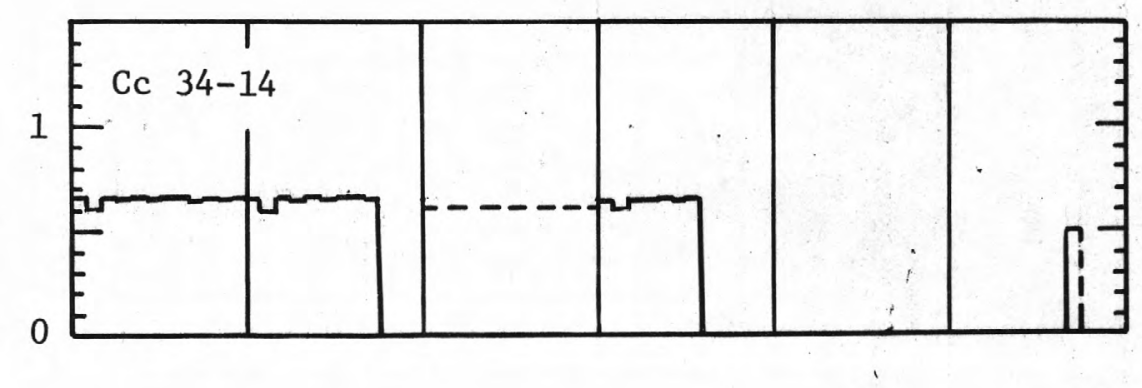

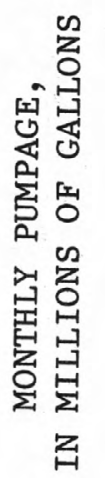

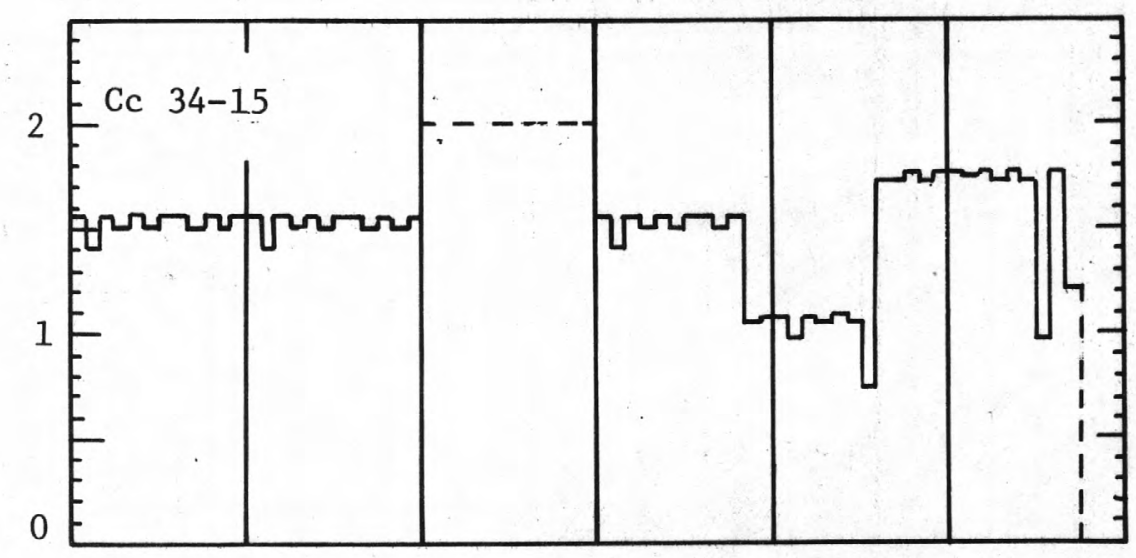

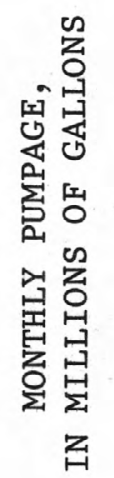

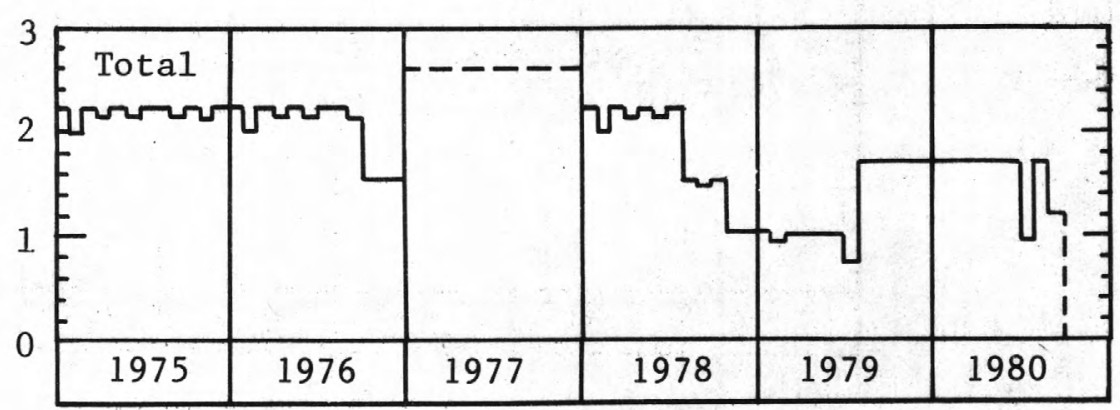

FIGURE 26.--Du Pont - Newport. Monthly pumpage from Cc34-14 and Cc34-15 and total monthly pumpage from we11 field, 1975- 80. 
FAIRWINDS
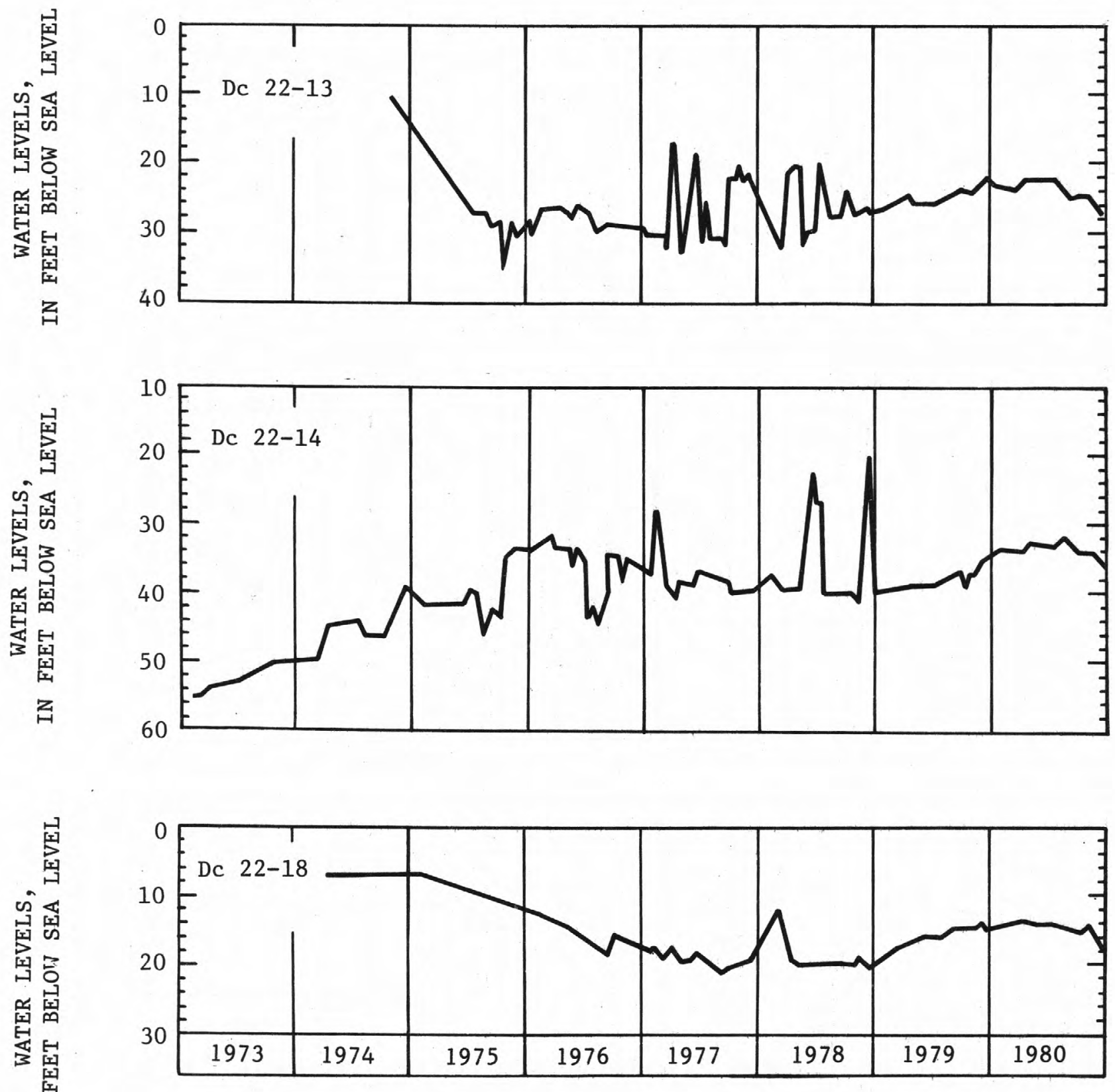

FIGURE 27.--Fairwinds. Water levels in Dc22-13 and Dc22-18, 1974-80, and Dc22-14, 1973-80. 
FAIRWINDS
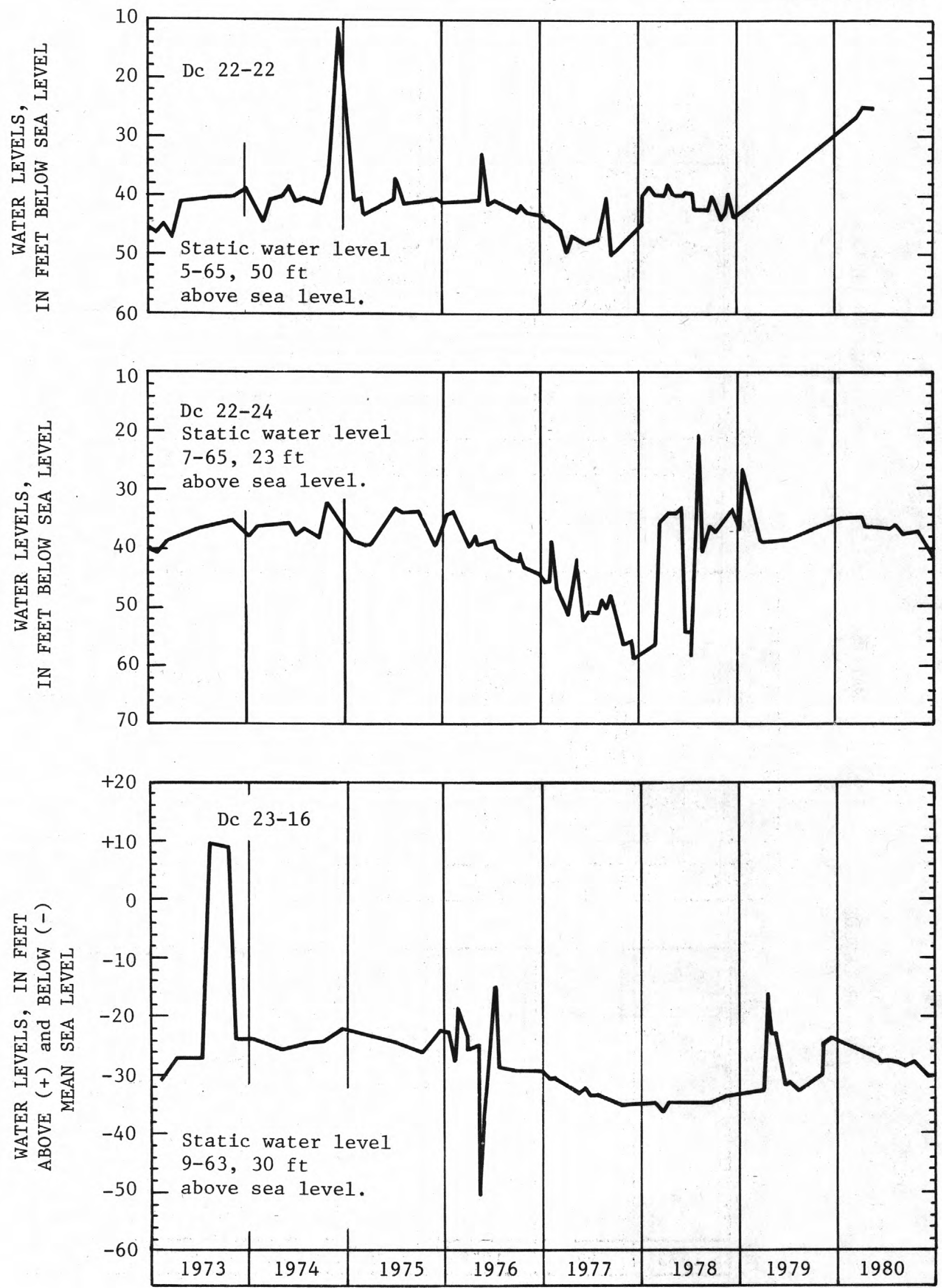

FIGURE 28.--Fairwinds. Water levels in Dc22-22, Dc22-24, and Dc23-16, 1973-80. 
FAIRWINDS

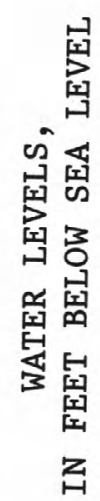
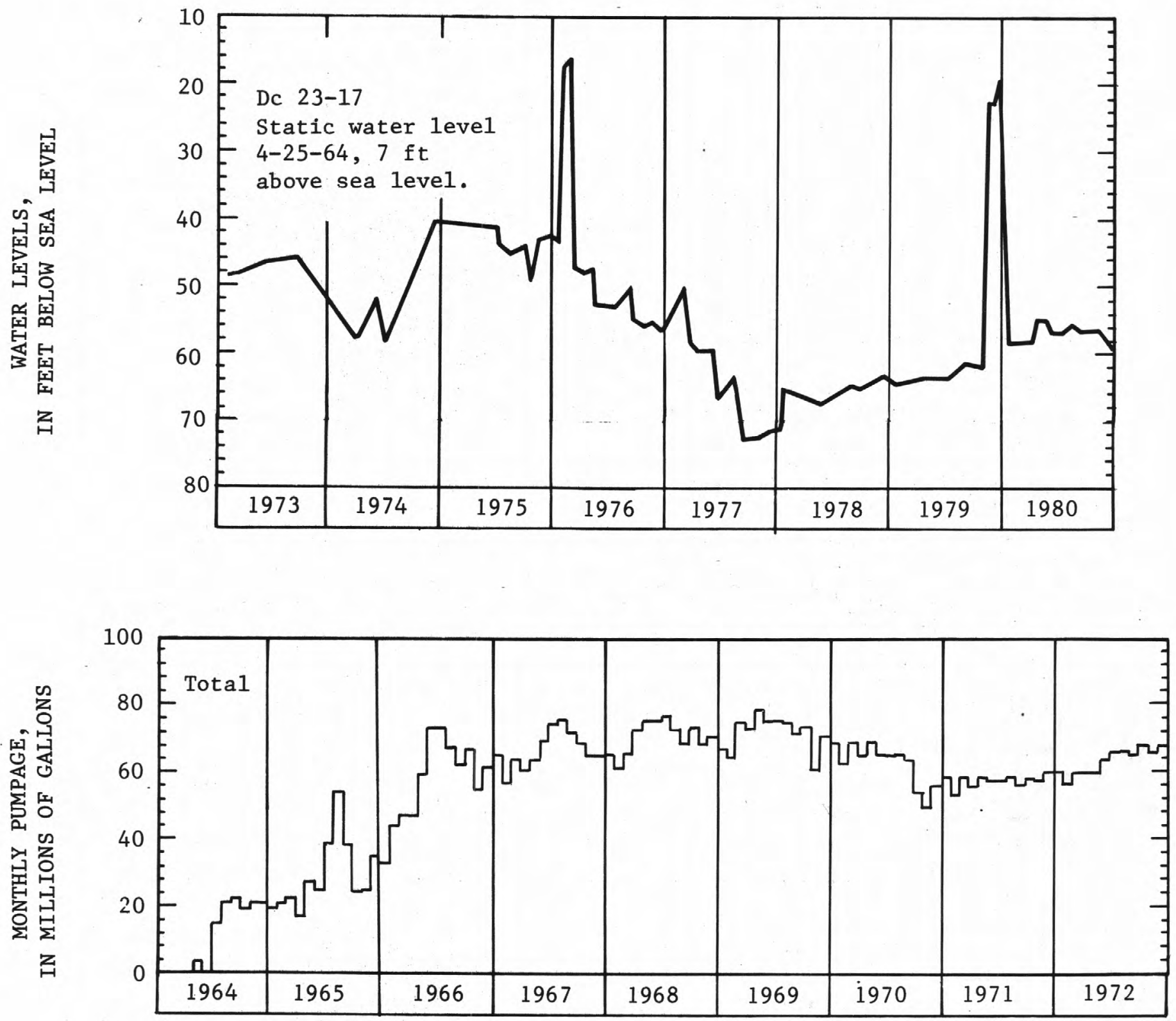

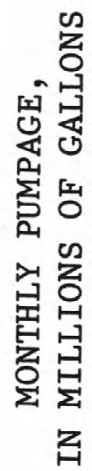

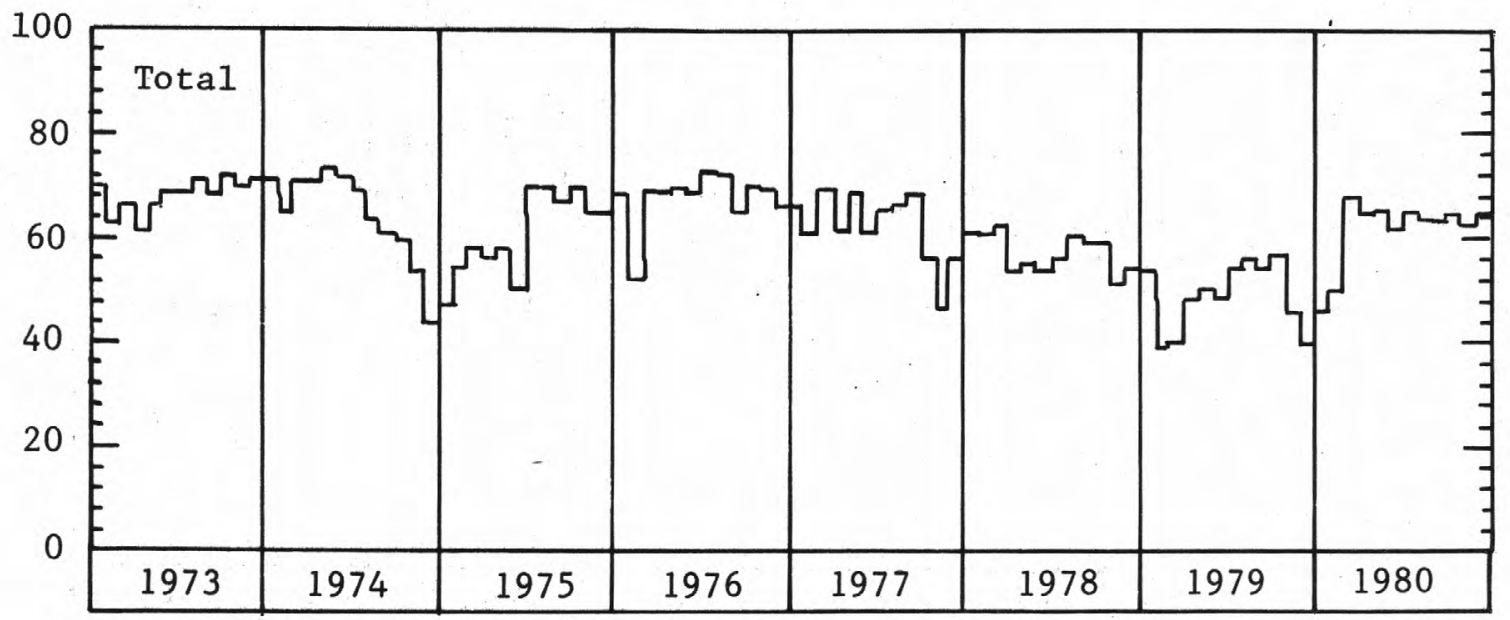

FIGURE 29.--Fairwinds. Total monthly pumpage-from well field, 1964-80. Water levels in Dc23-17, 1973-80. 

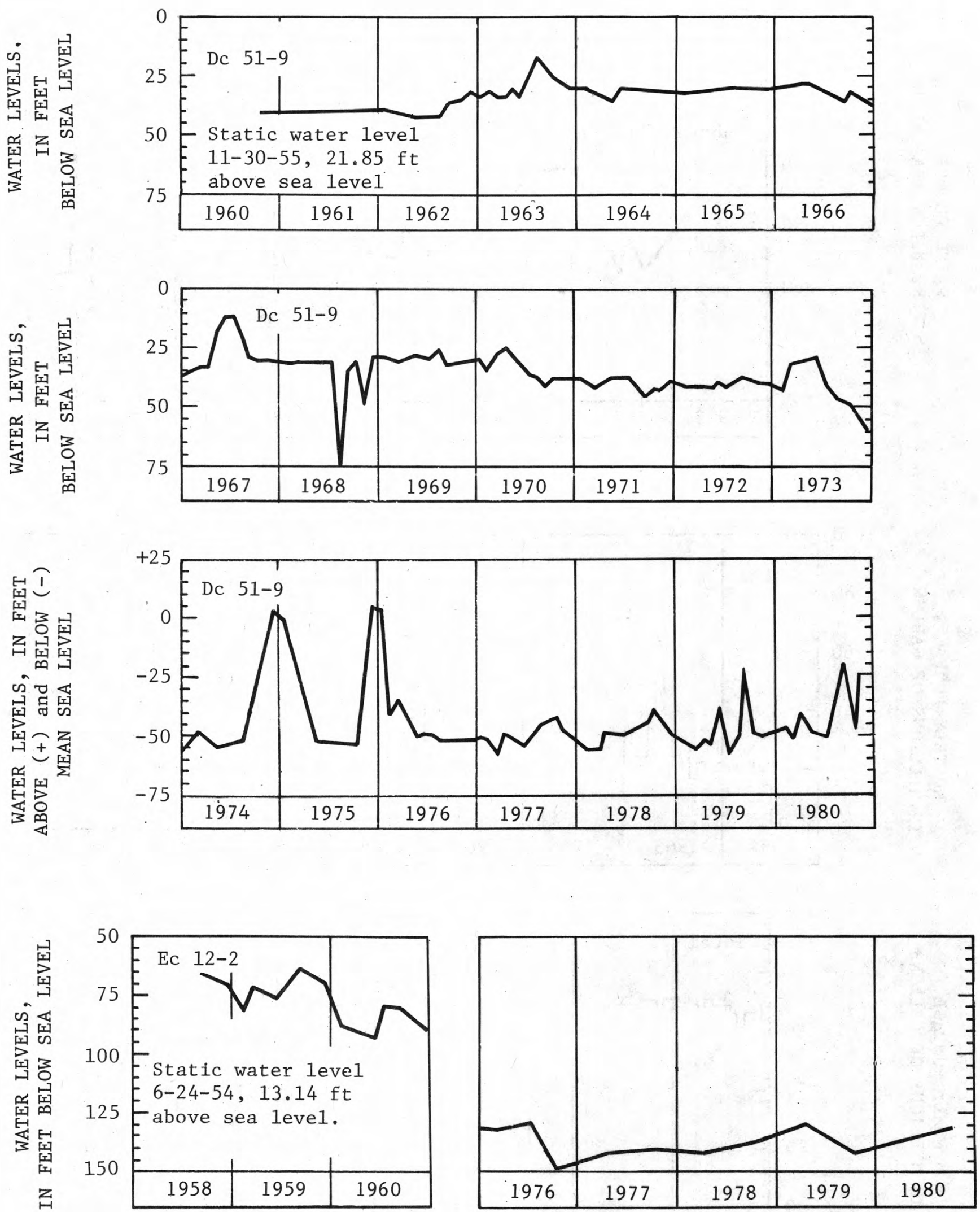

FIGURE 30.--Getty. Water leve1s in Dc51-9, 1960-80, and Ec12-2, 1958-60, and 1976-80. 
GETTY
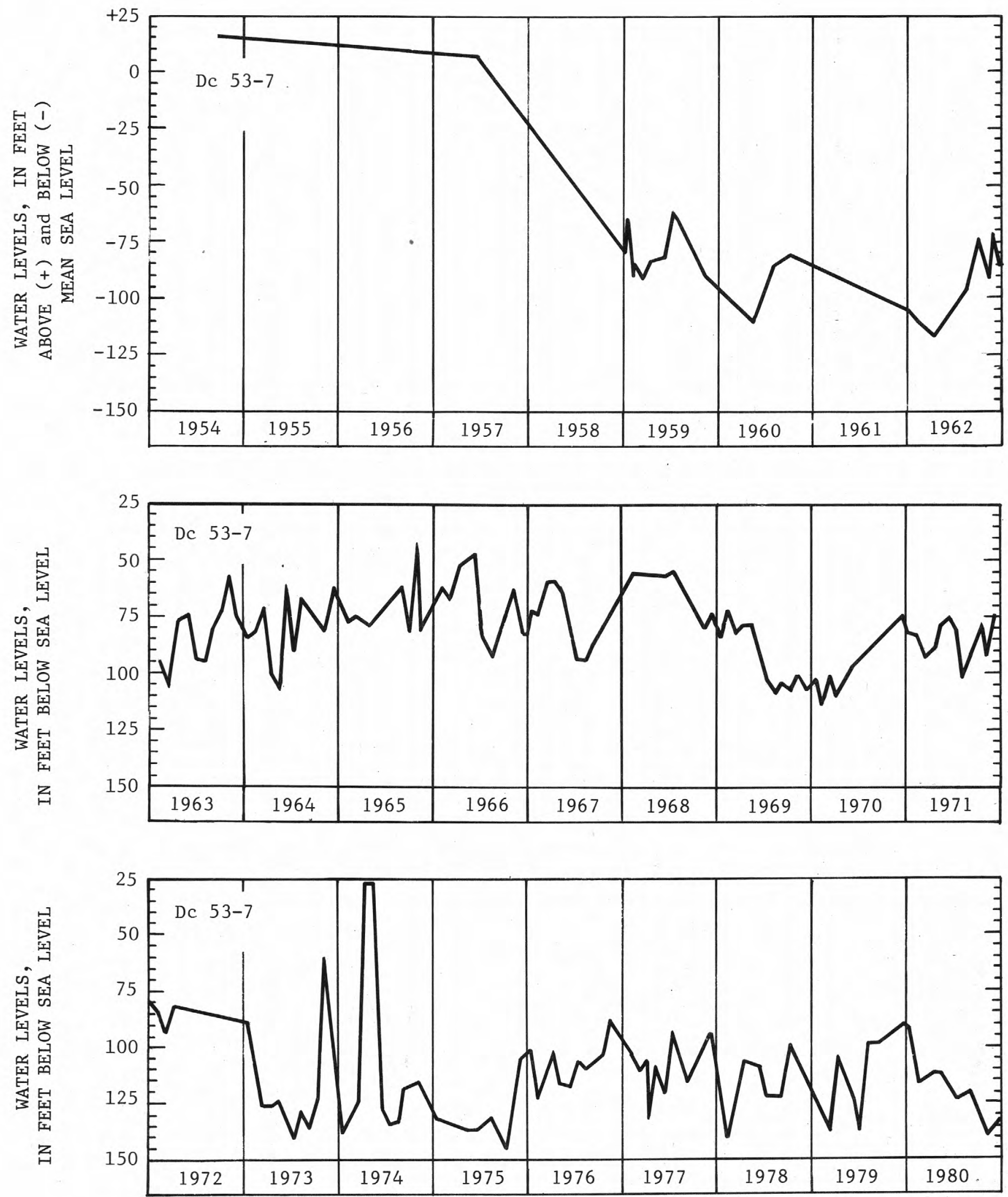

FIGURE 31.--Getty. Water leve1s in Dc53-7, 1954-80. 
GETTY
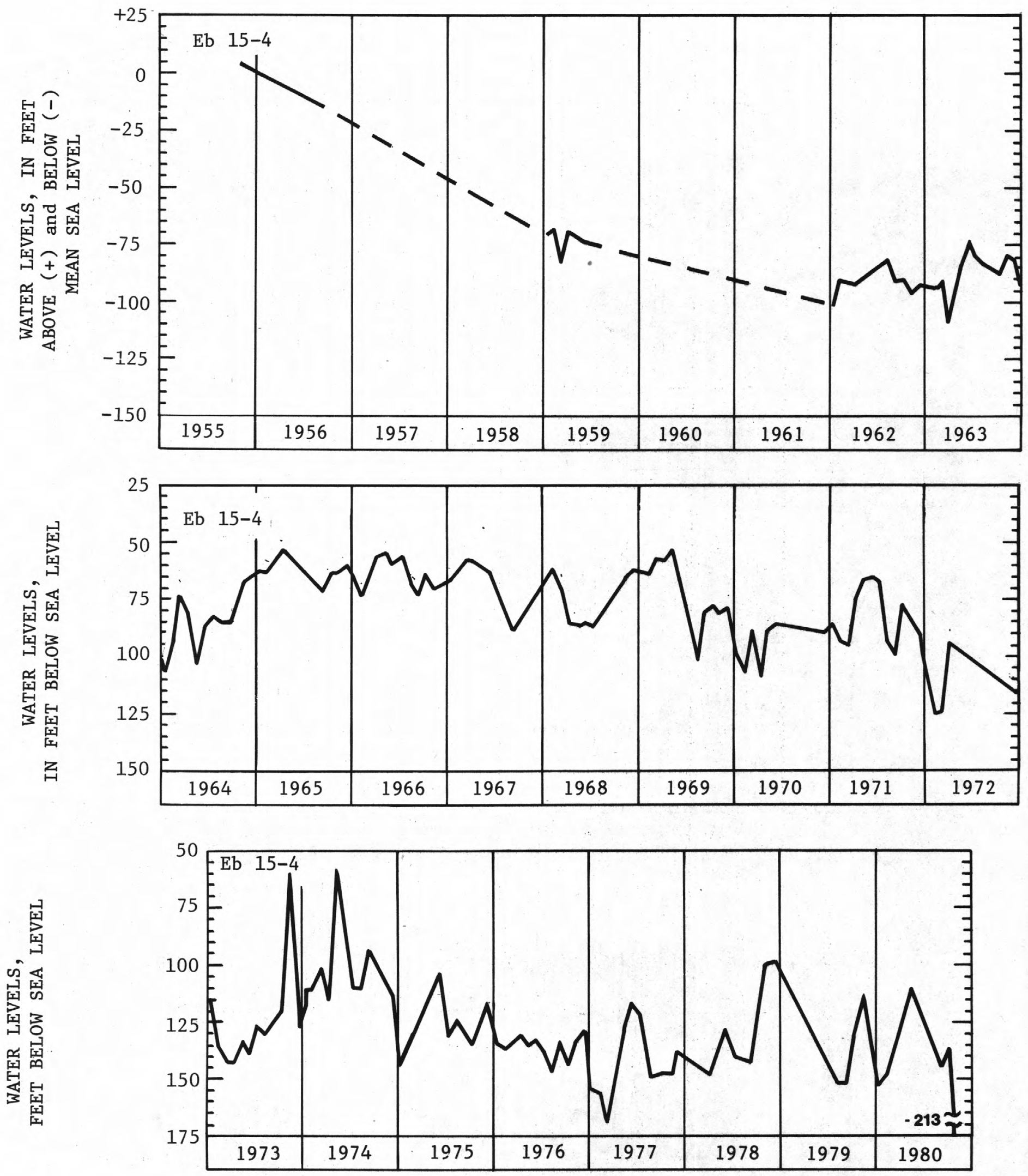

FIGURE 32.--Getty. Water levels in Eb15-4, 1955-80. 


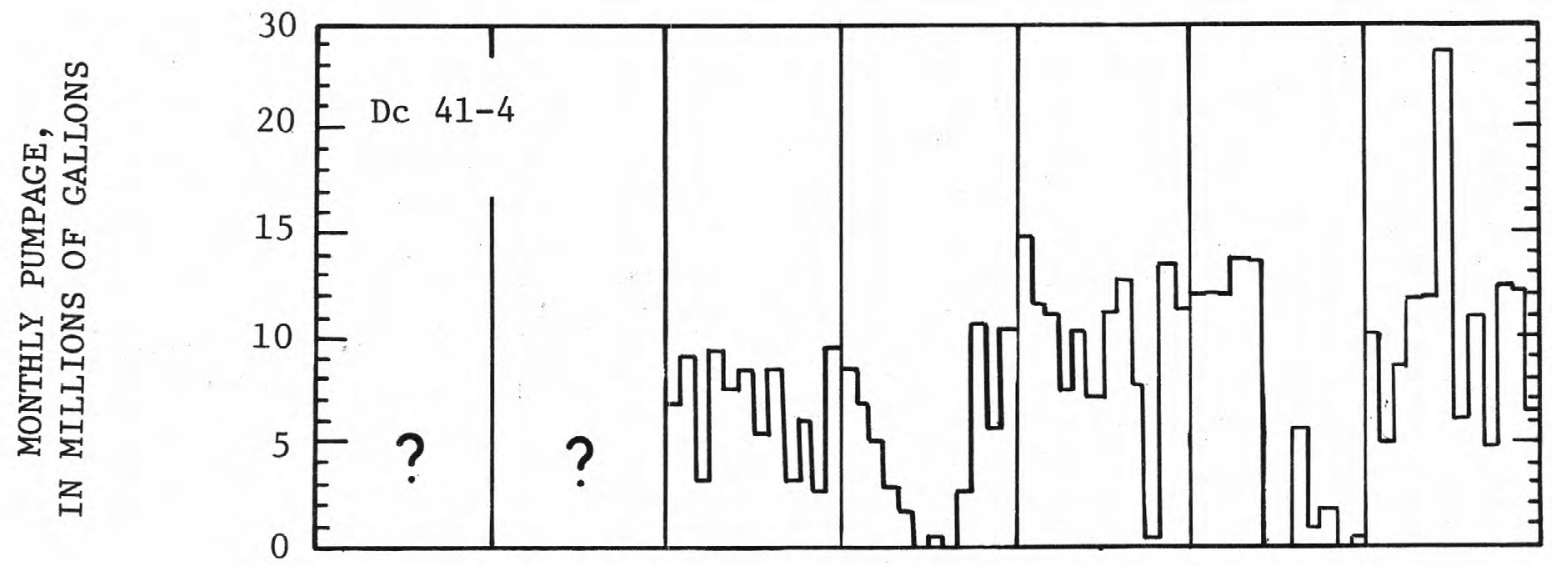

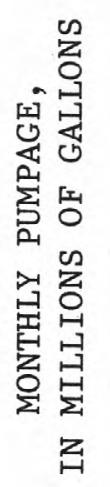

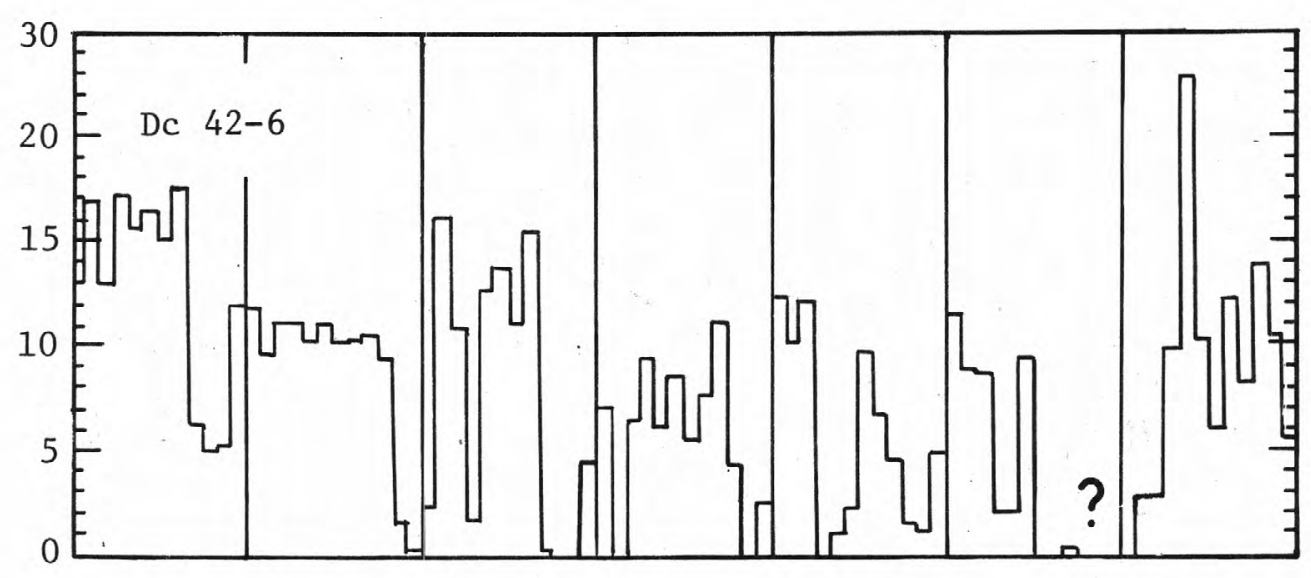

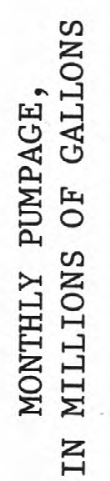

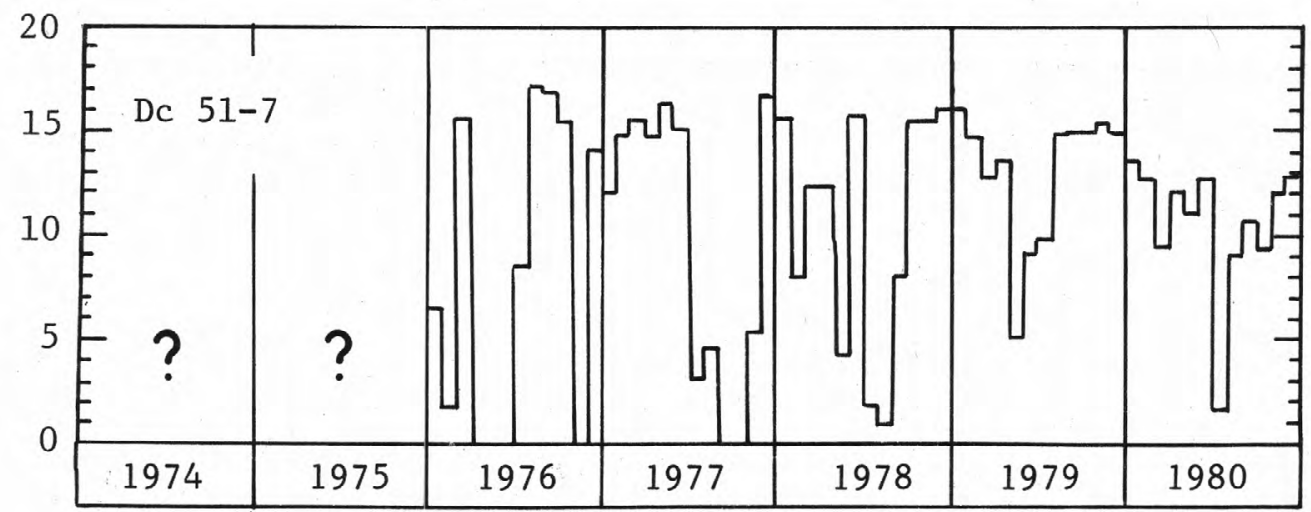

FIGURE 33.--Getty. Monthly pumpage from Dc41-4 and Dc51-7 1976-80, and Dc42-6, 1974-80. 
GETTY

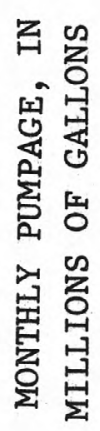

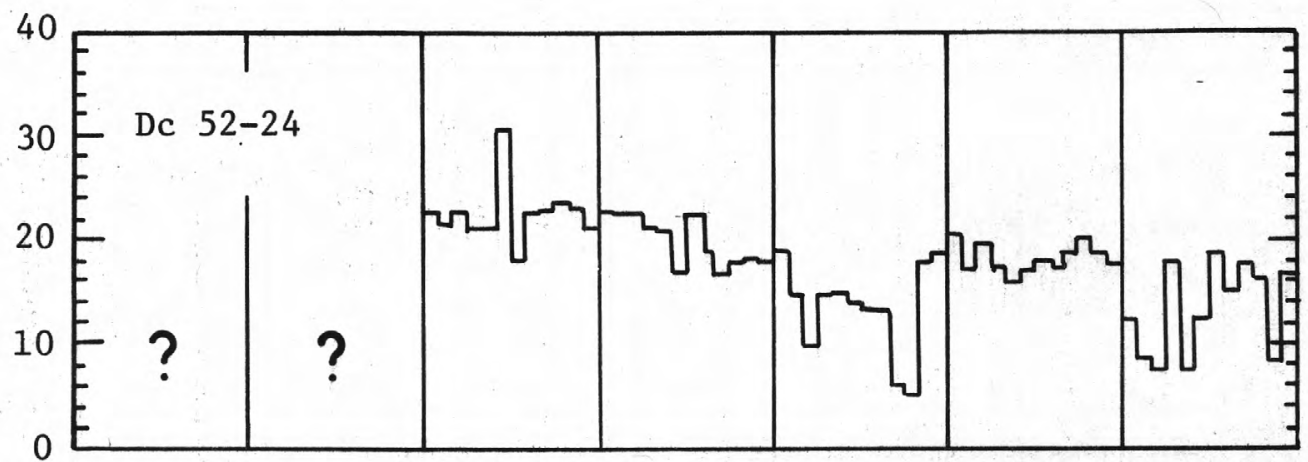

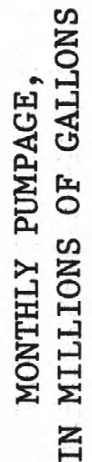
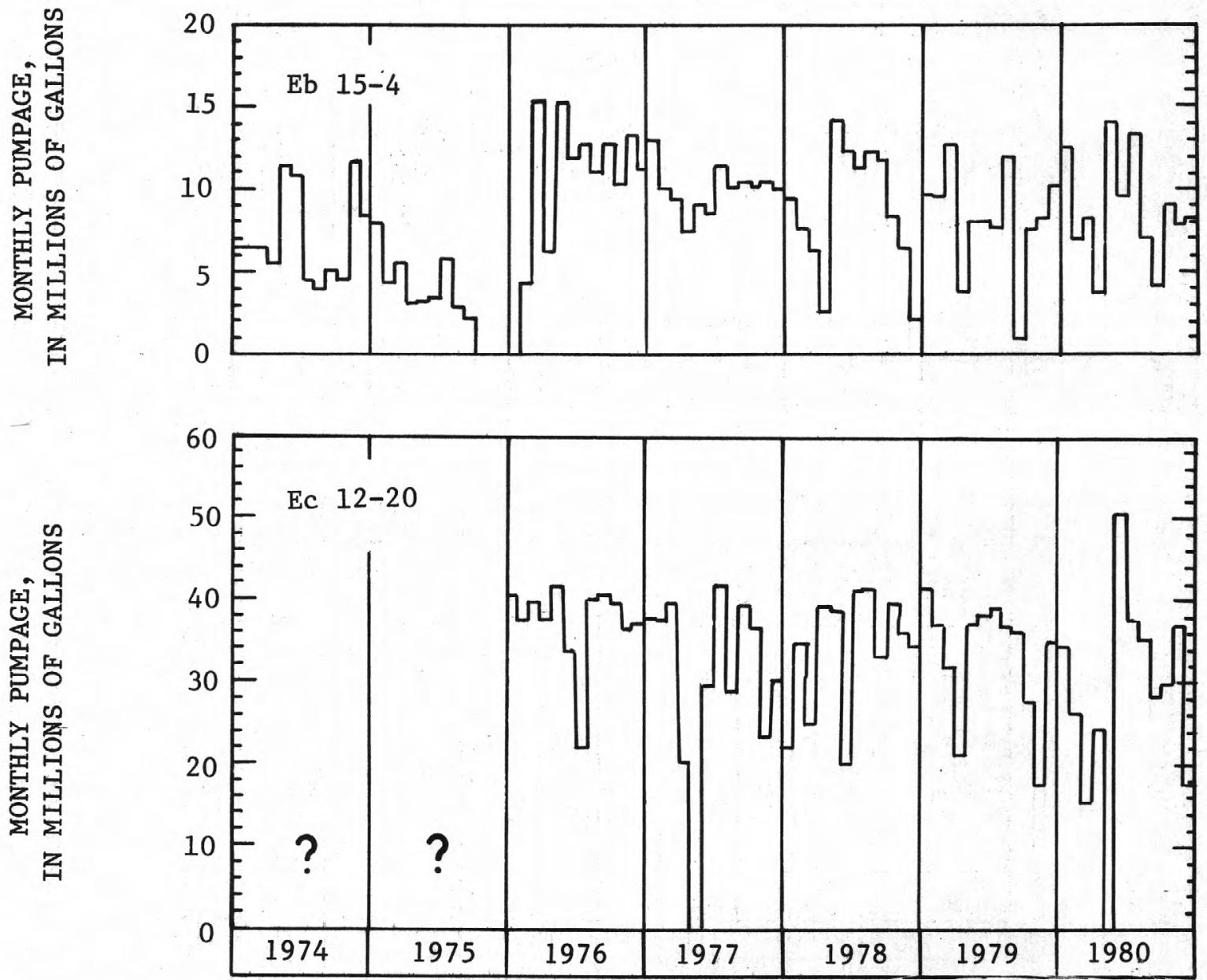

FIGURE 34.--Getty. Monthly pumpage from Dc52-24 and Ec12-20, 1976-80, and Eb15-4, 1974-80. 
GETTY

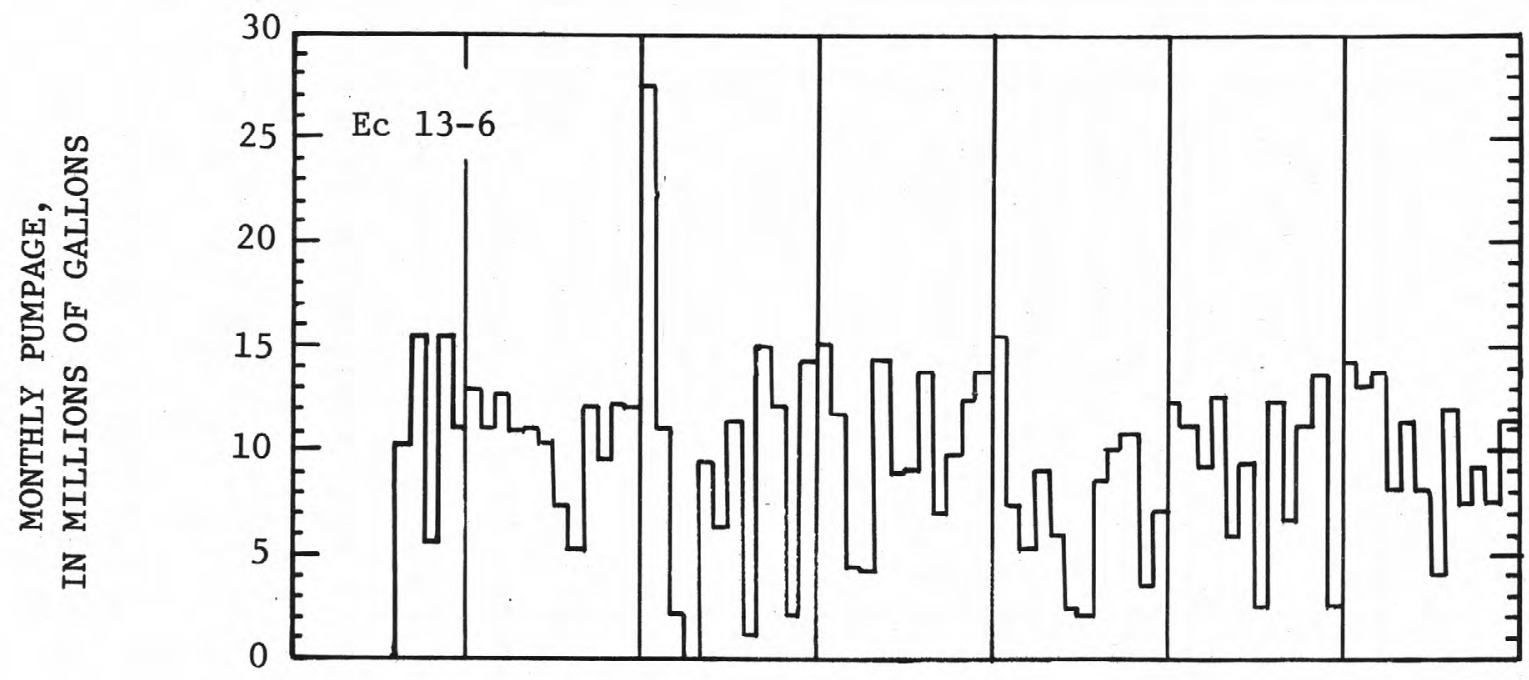

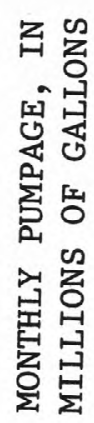

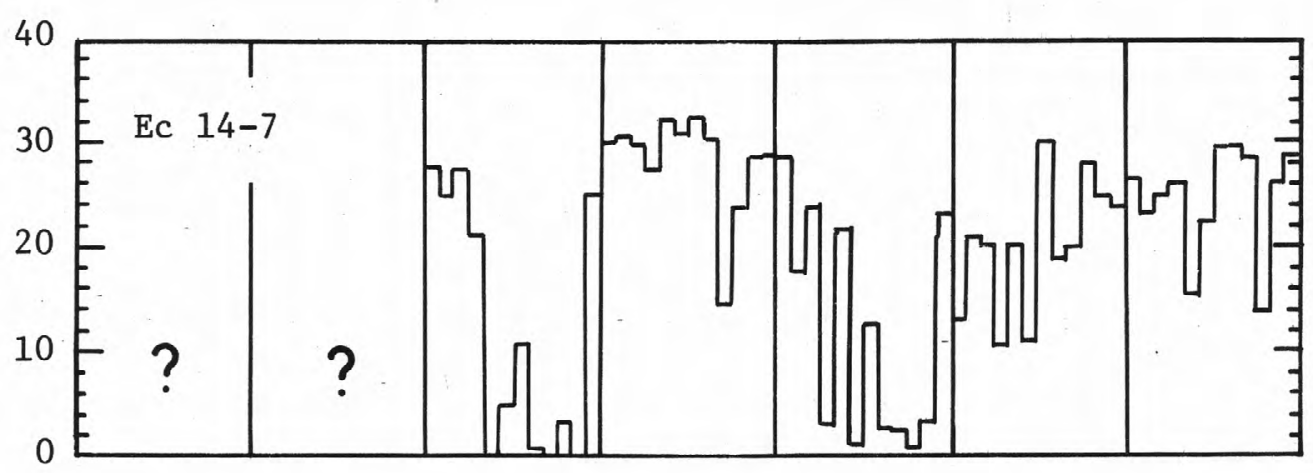

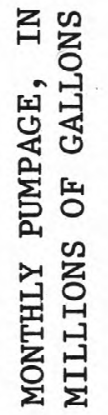

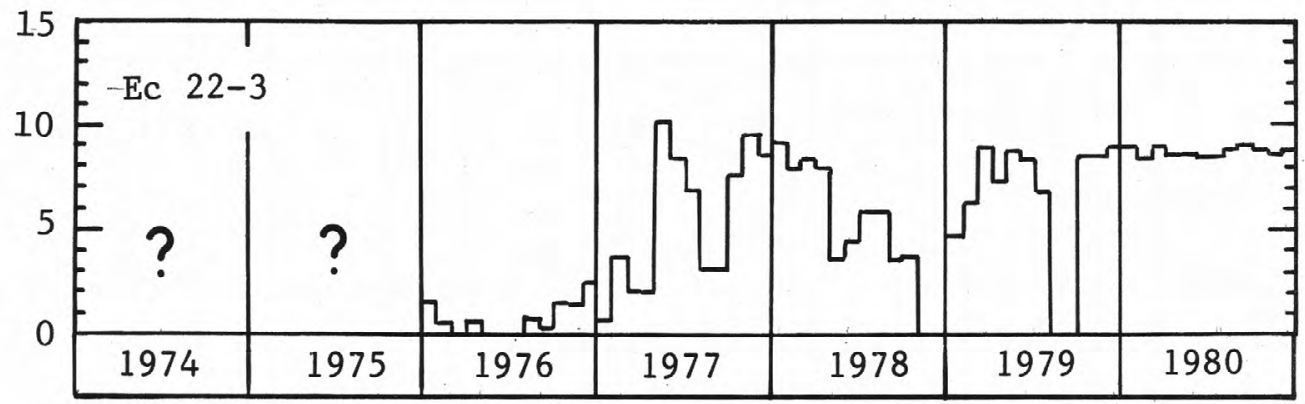

FIGURE 35.--Getty. Month1y pumpage from Ec13-6, 1974-80 and Ec14-7 and Ec22-3, 1976-80. 
GETTY
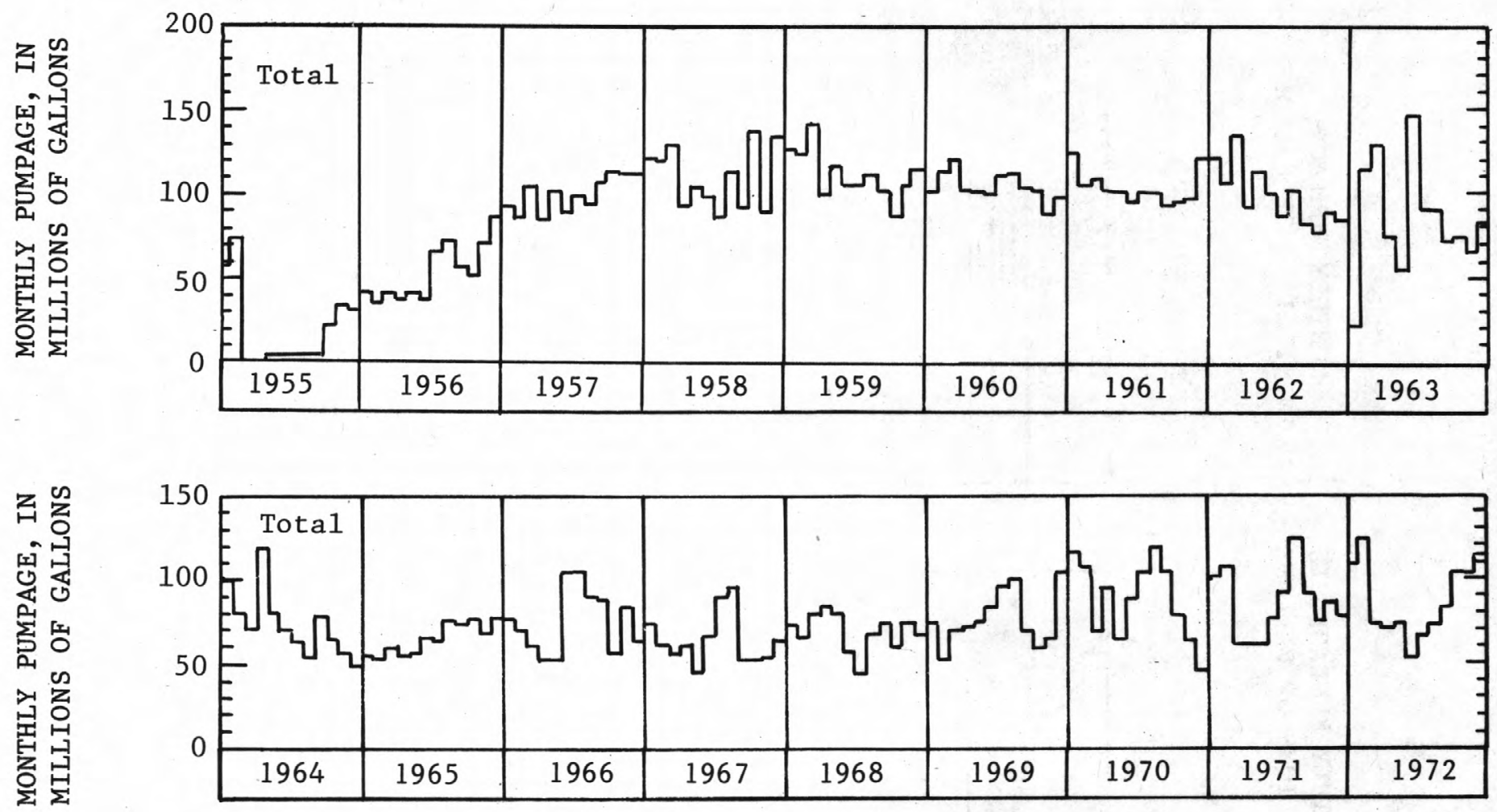

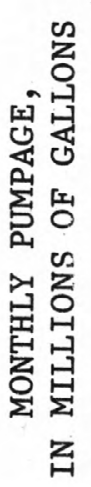

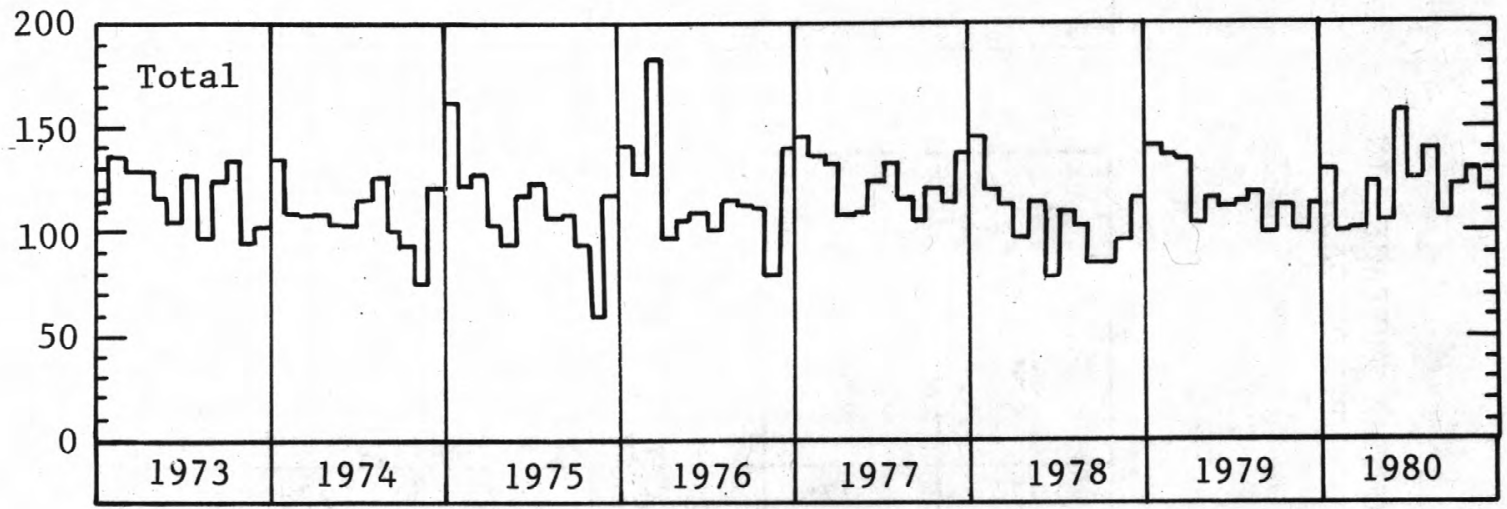

FIGURE 36.--Getty. Total monthly pumpage from well field, 1955- 80 . 


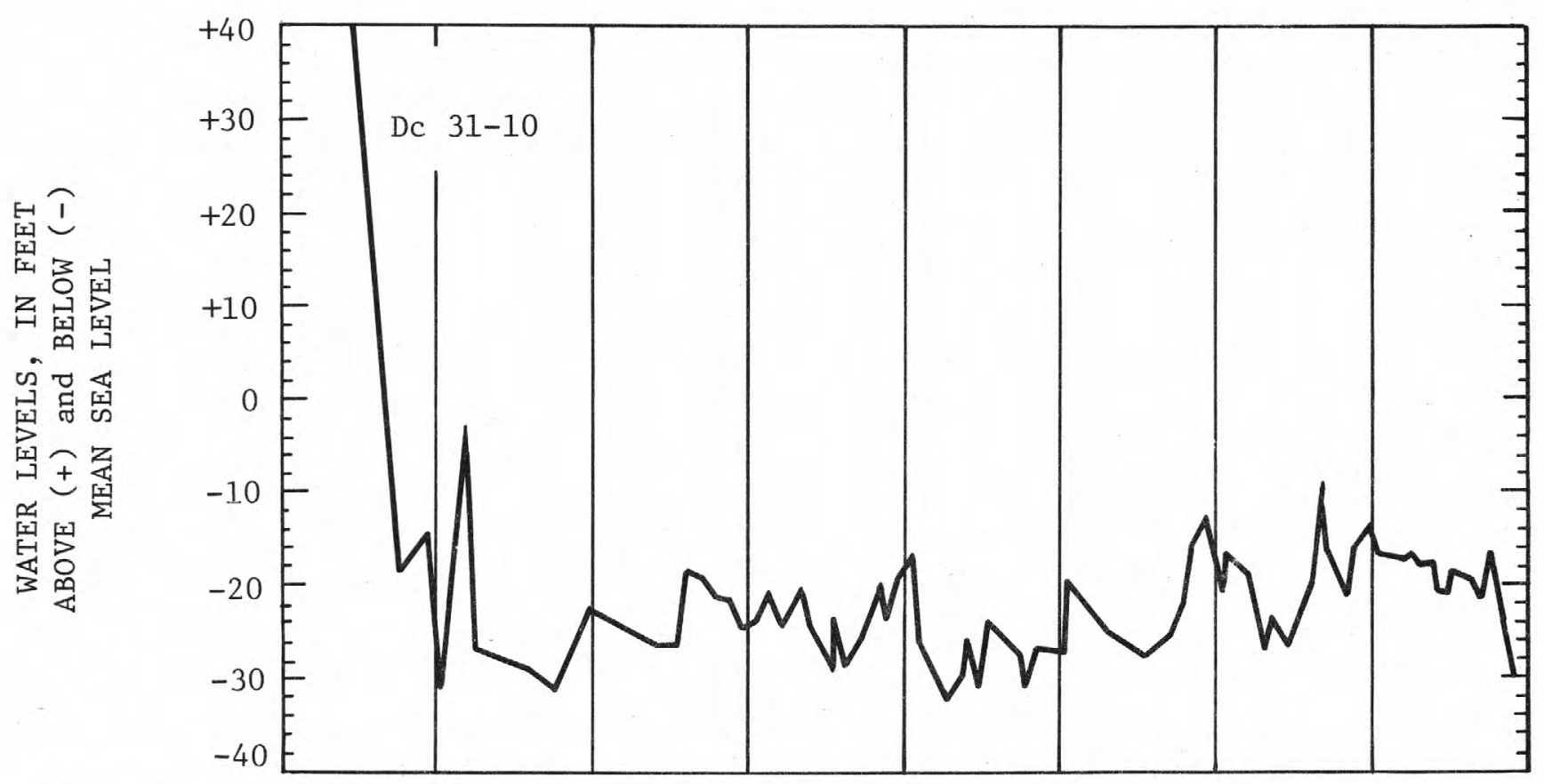

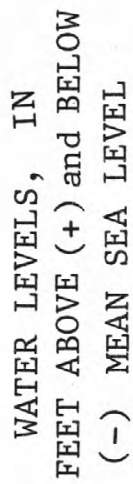

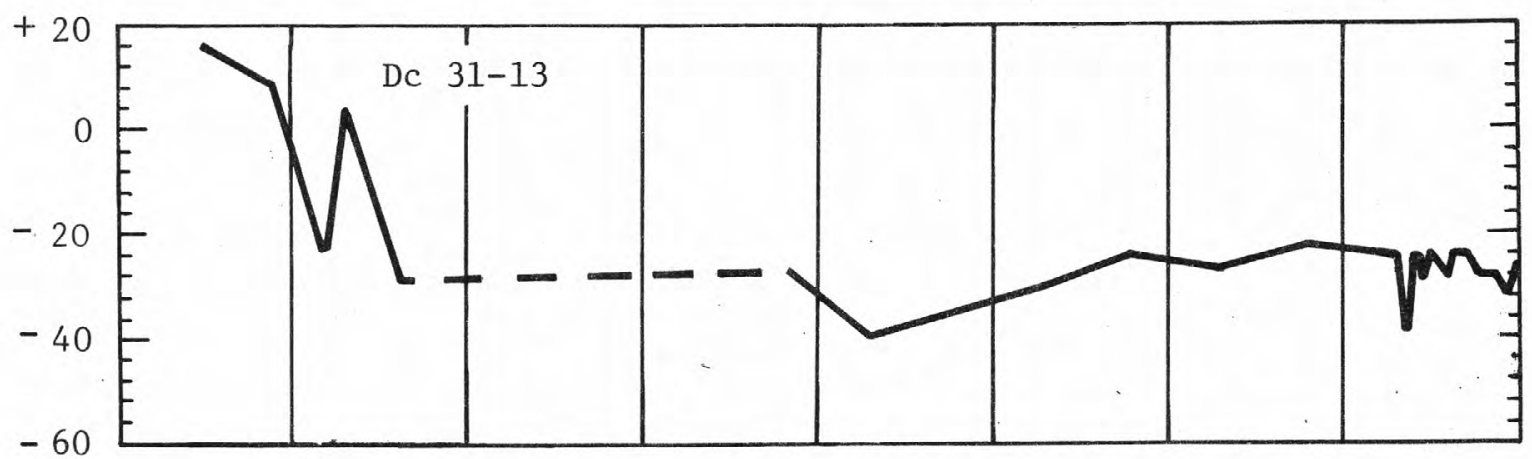

置

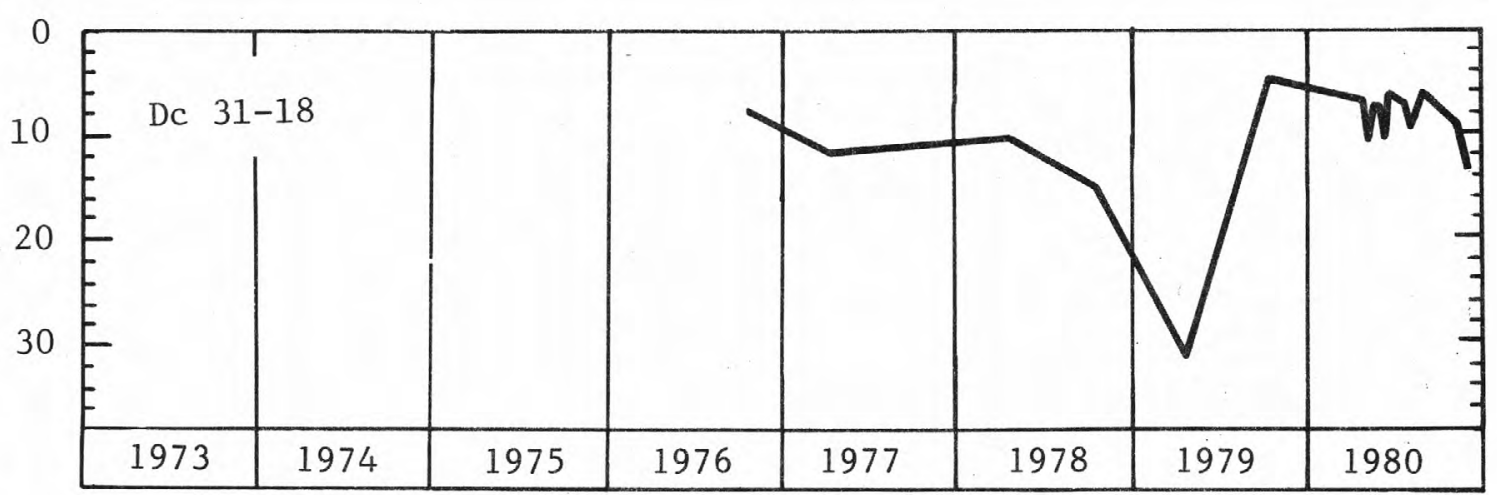

FIGURE 37.--Glendale. Water levels in Dc31-10 and Dc31-13, 1973-80, and Dc31-18, 1976-80. 
GLENDALE

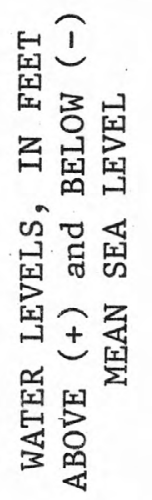

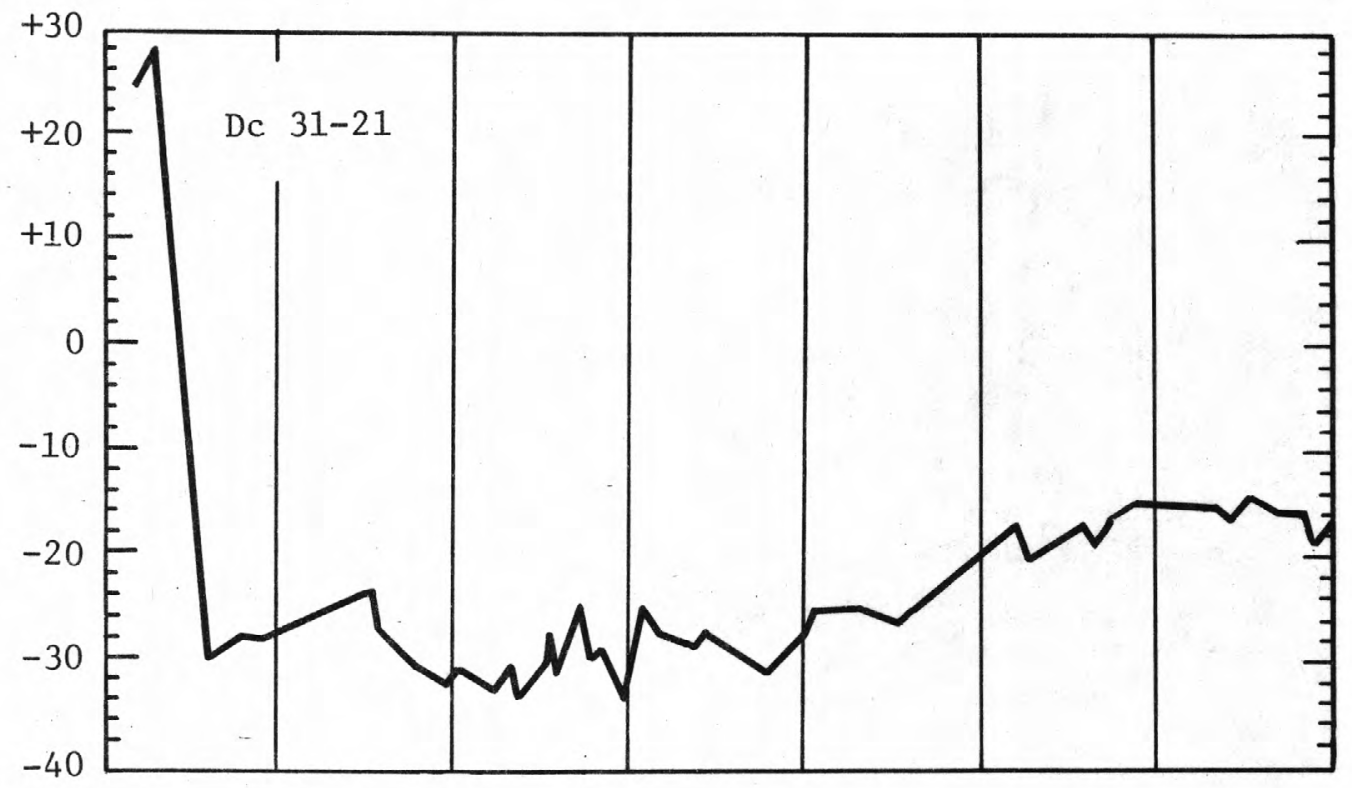

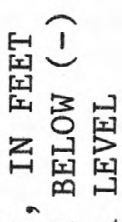

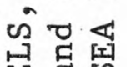

空 ฮั थ

空士孞

幽

岳空

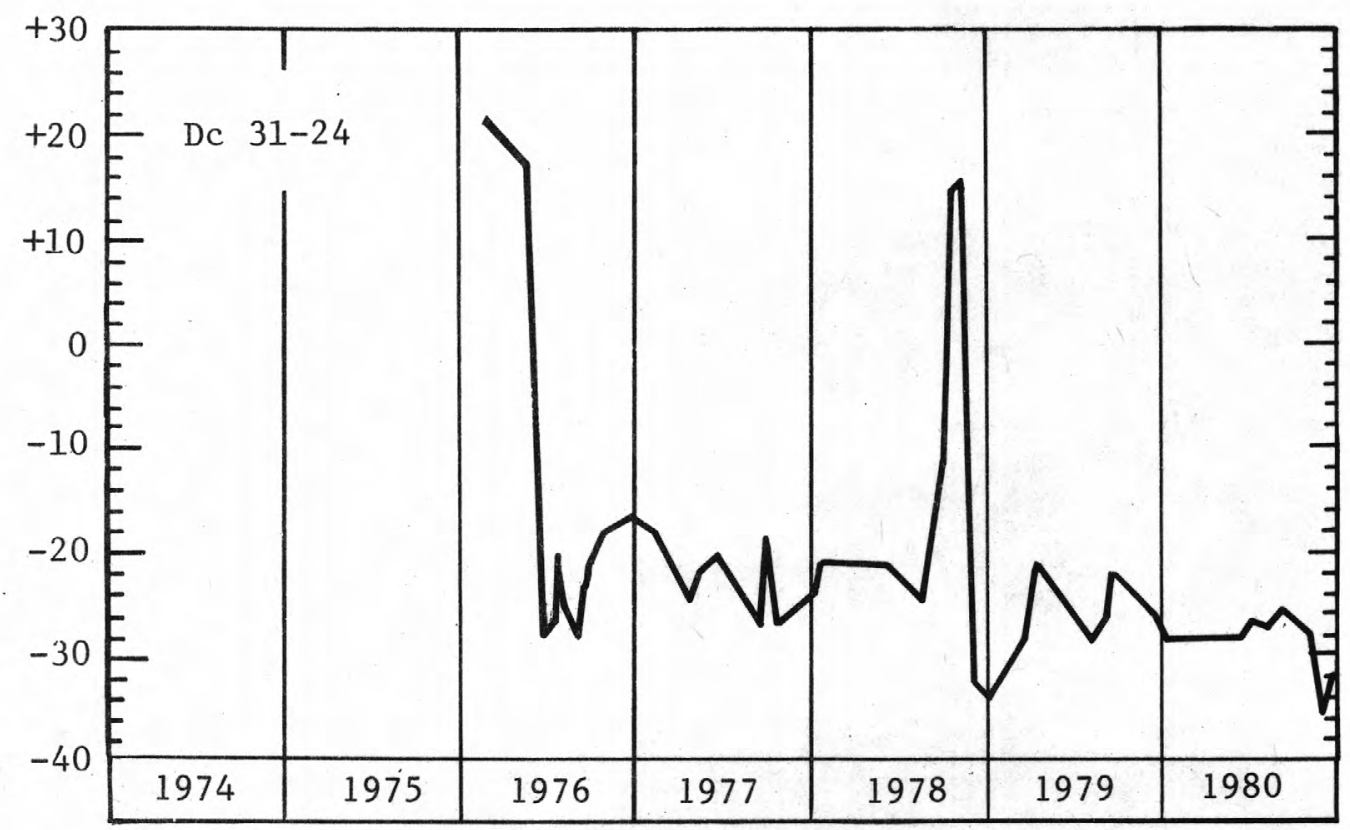

FIGURE 38.--Glendale. Water levels in Dc31-21, 1974-80, and Dc31-24, 1976-80. 

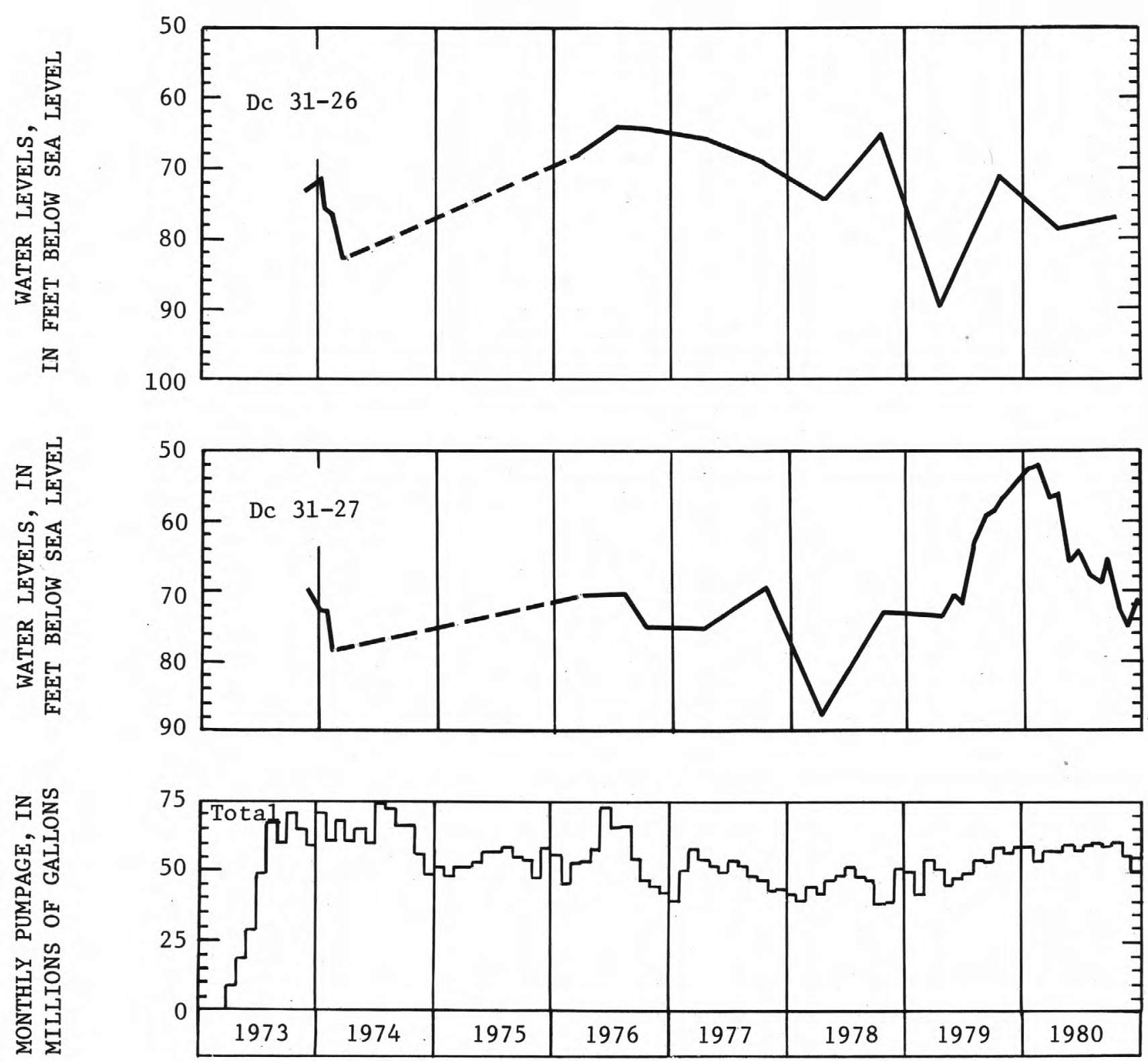

FIGURE 39.--Glendale. Total monthly pumpage from well field, 1973-80. Water levels in Dc31-26 and Dc31-27, 1973- 80 . 
GOODRICH
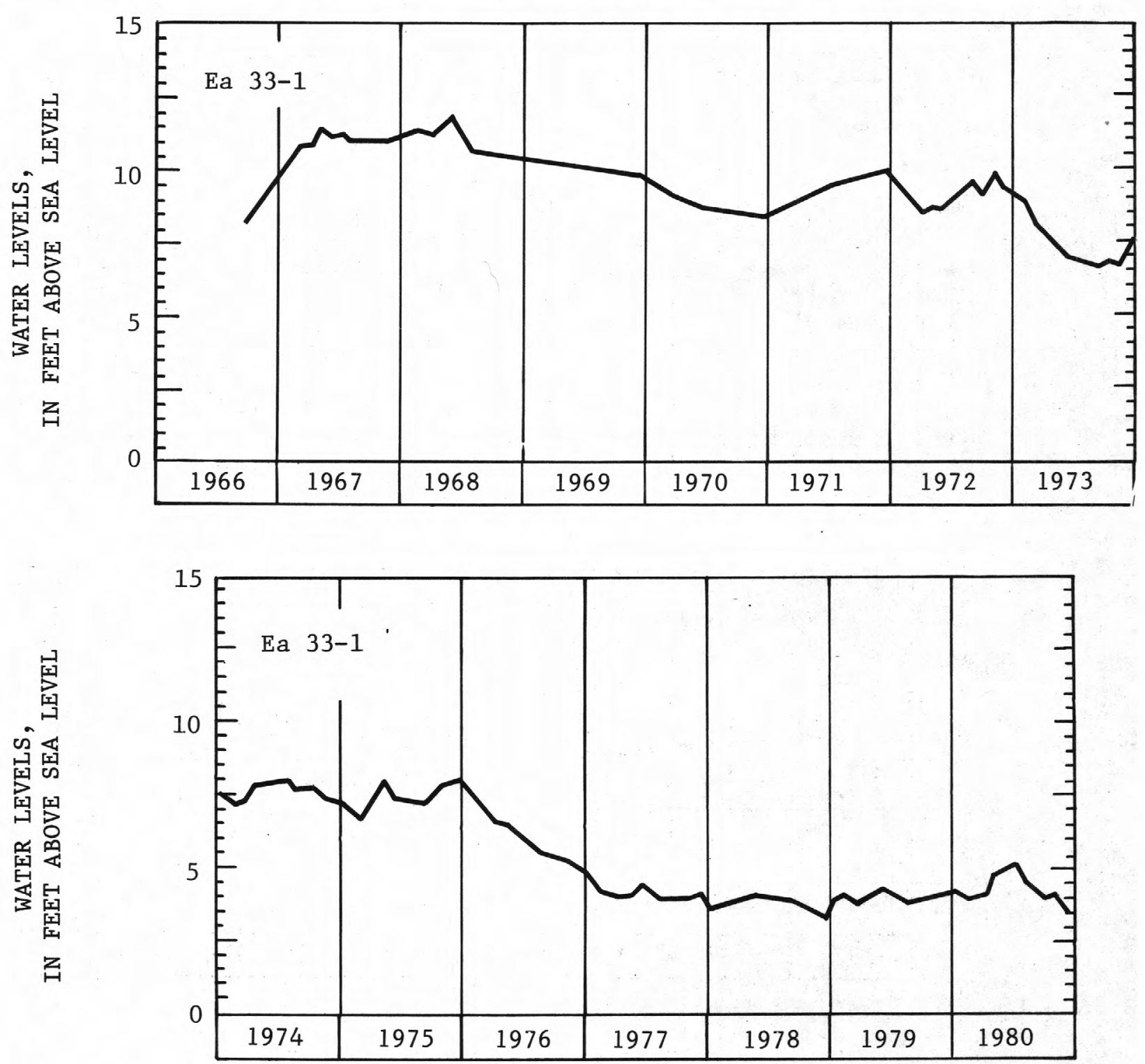

FIGURE 40.--Goodrich. Water levels in Ea33-1, 1966-80. 

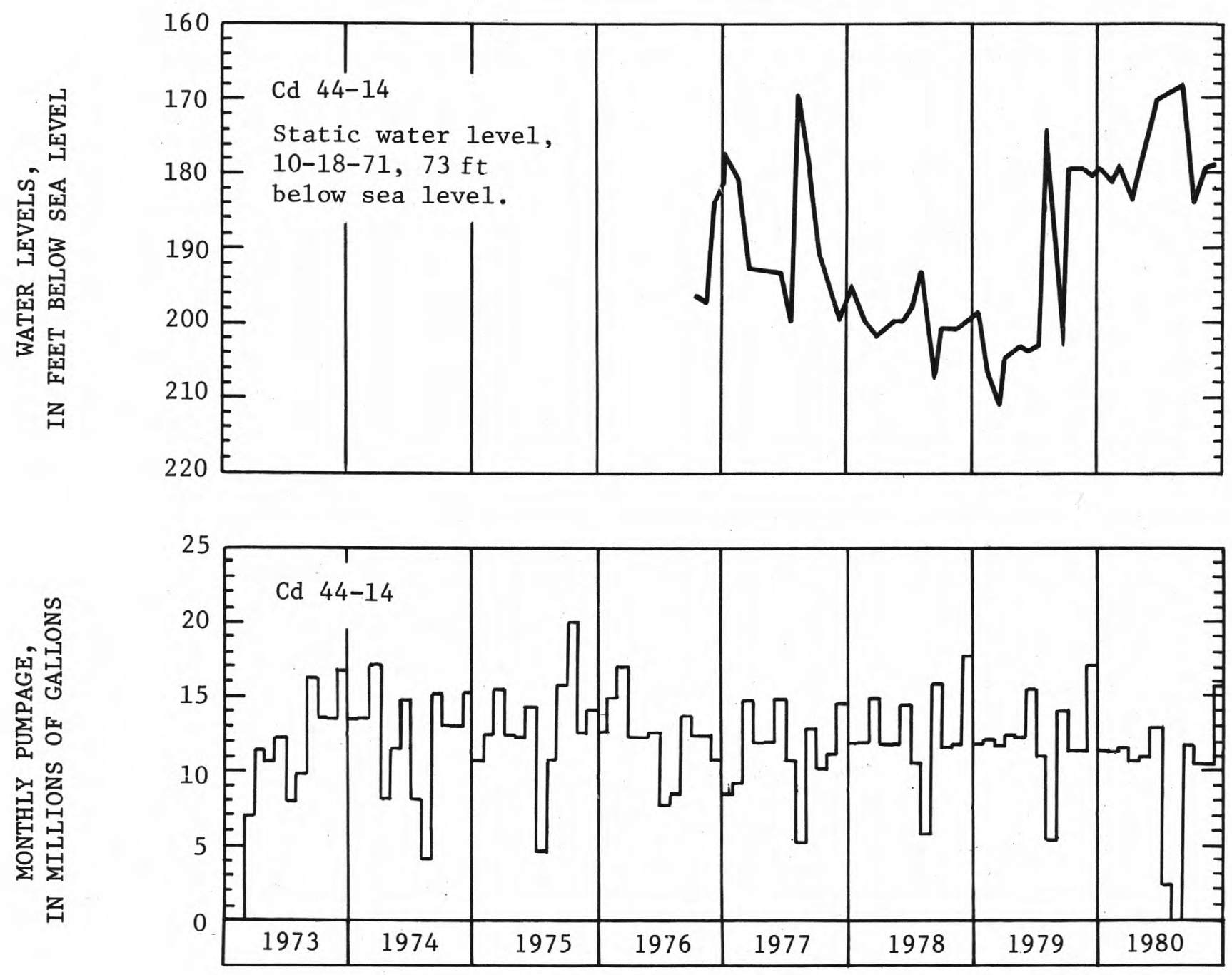

FIGURE 41.--ICI. Month1y pumpage from Cd44-14, 1973-80. Water levels in Cd44-14, 1976-80. 

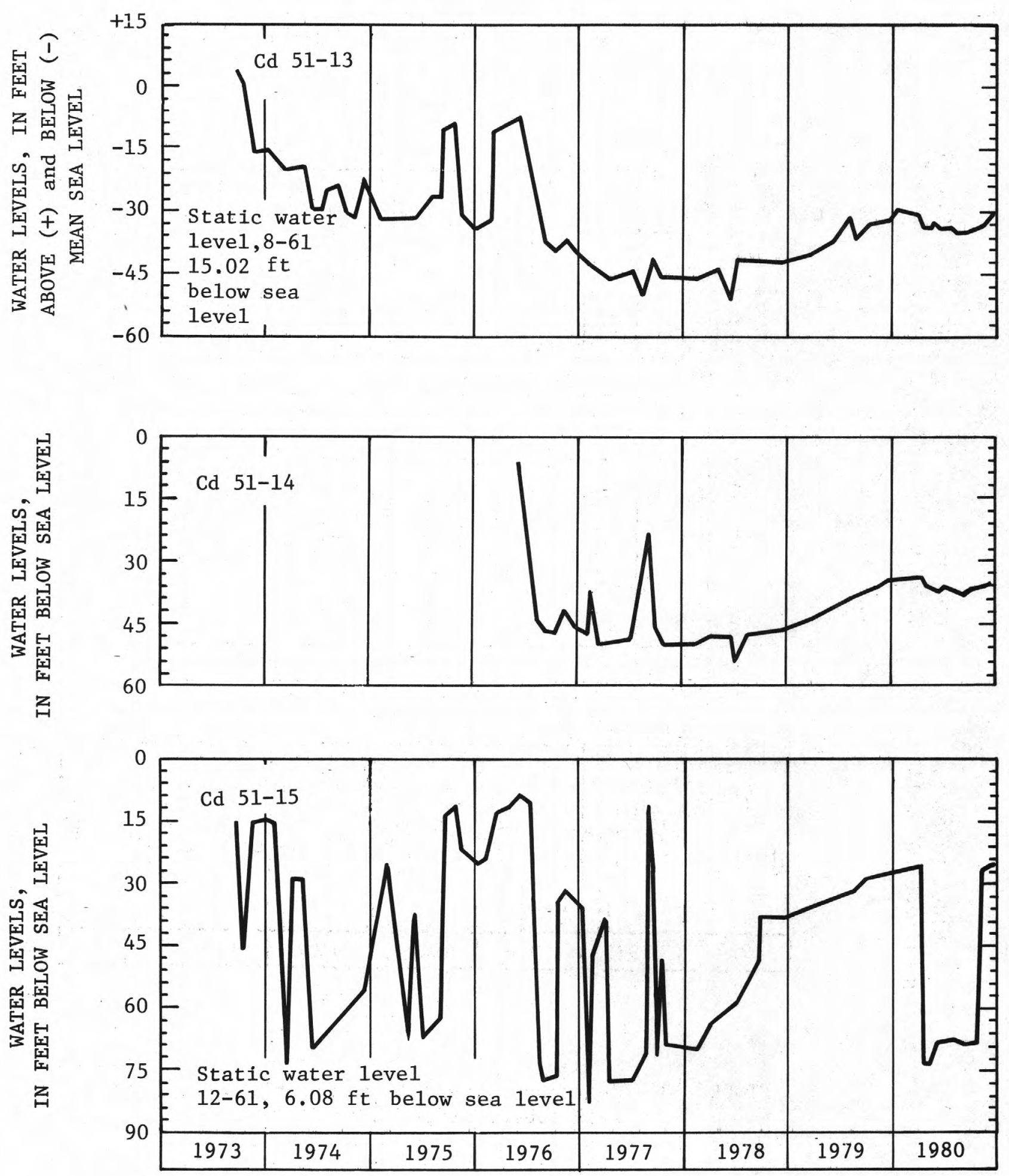

FIGURE 42.--Jefferson Farms. Water levels in Cd51-13 and Cd51-15, 1973-80, and Cd51-14, 1976-80. 

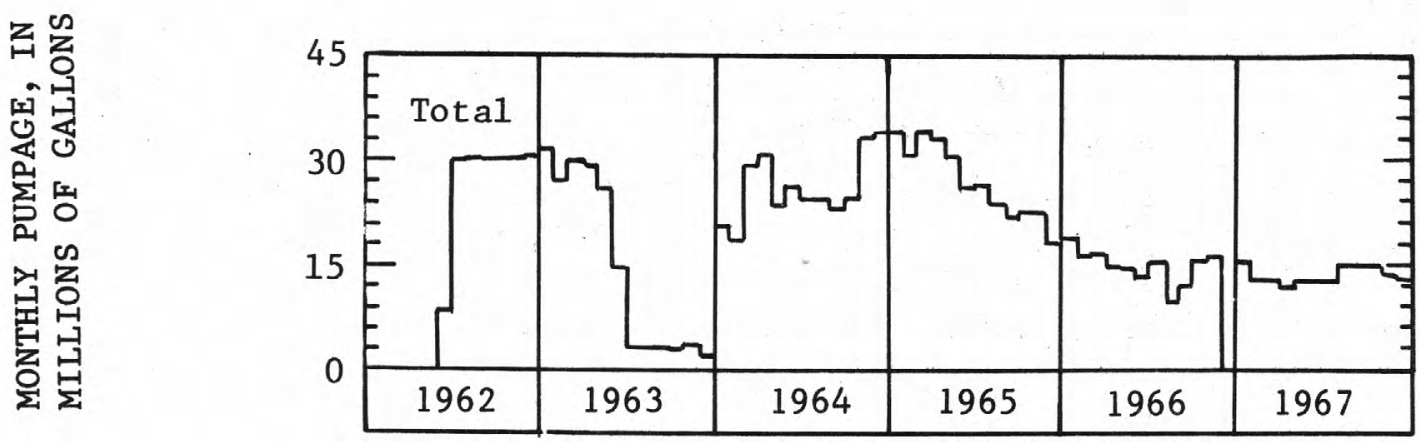

z恕

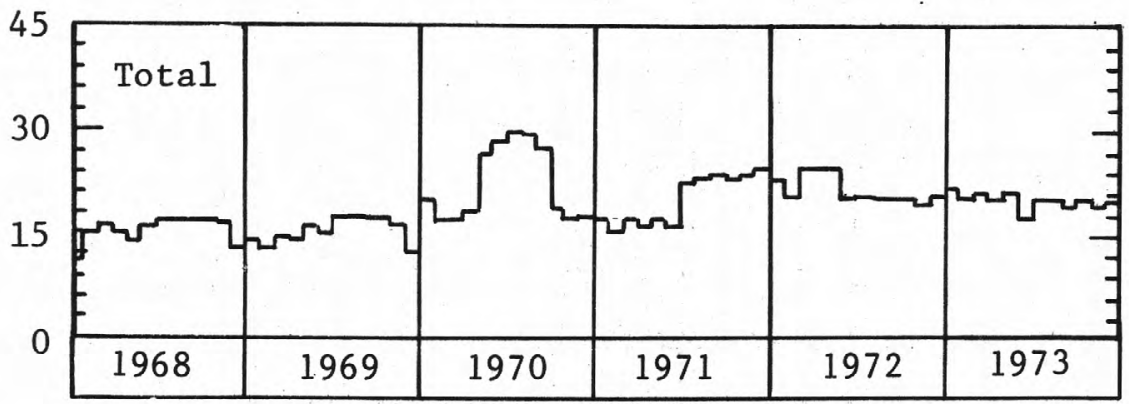

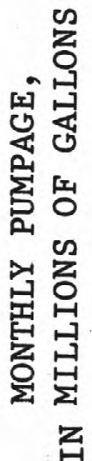

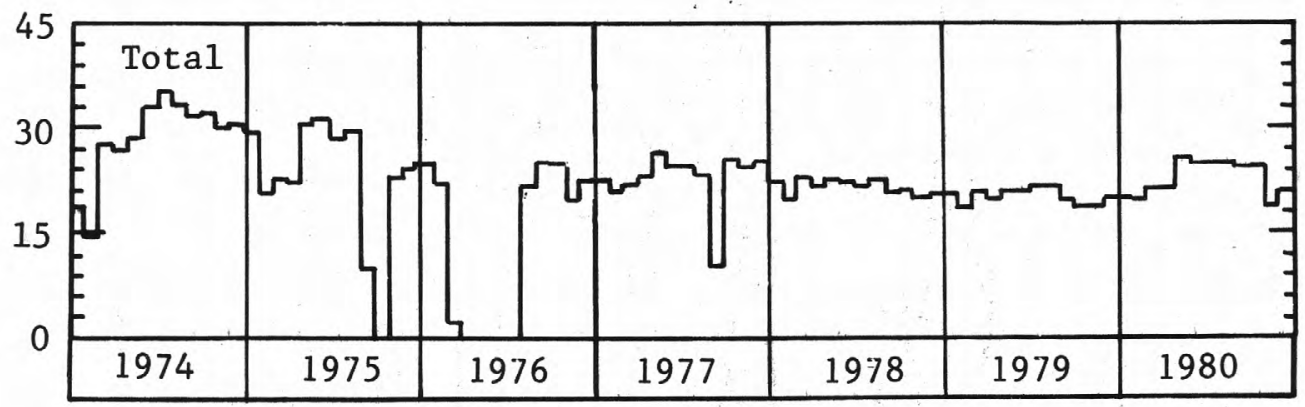

FIGURE 43.--Jefferson Farms. Total monthly pumpage from well field, 1962-80. 

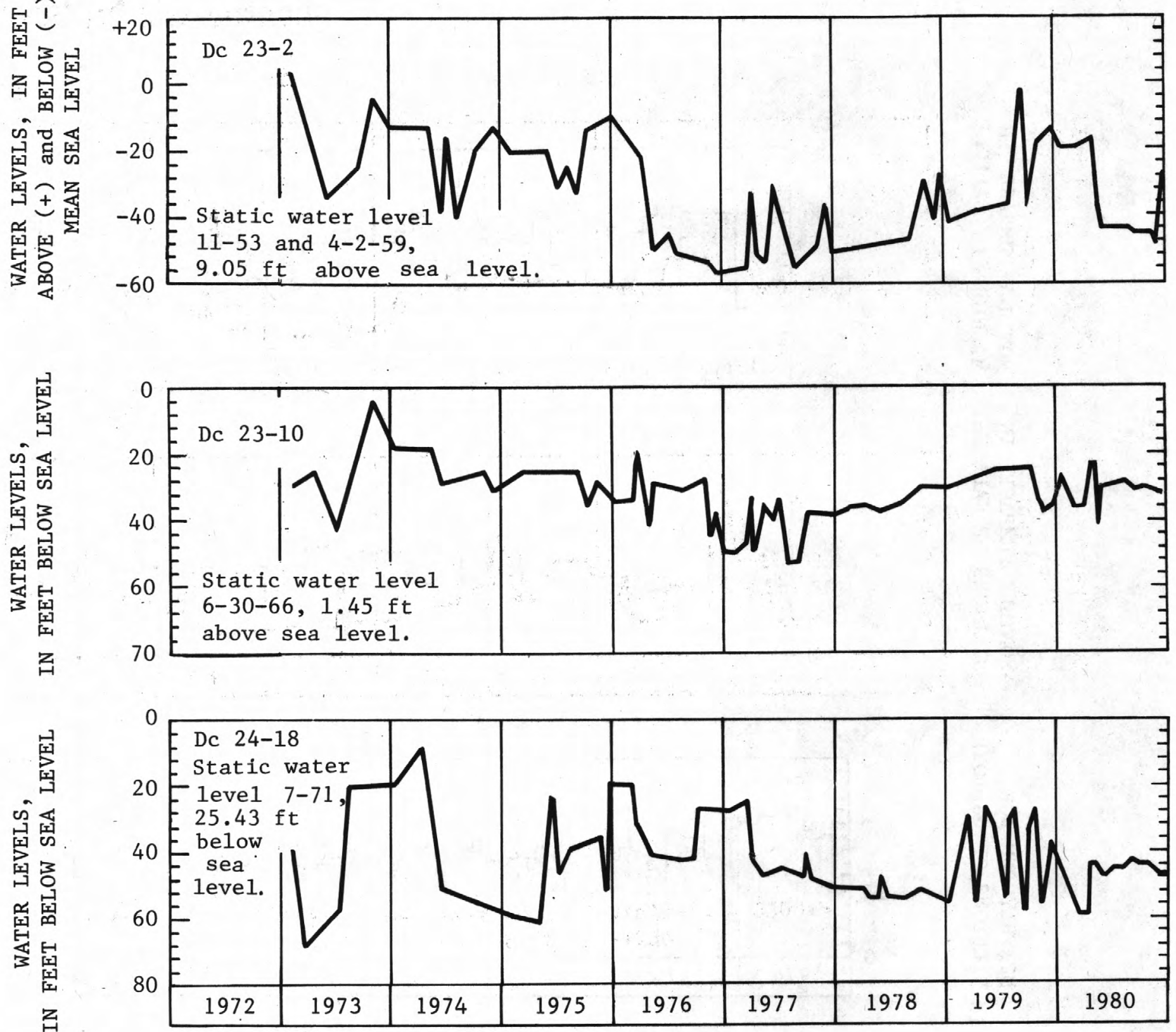

FIGURE 44.--Llangollen Estates. Water levels in Dc23-2, Dc23-10, and Dc24-18, 1973-80. 


\section{LLANGOLLEN ESTATES}

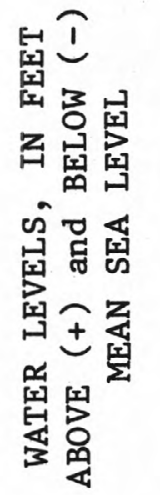
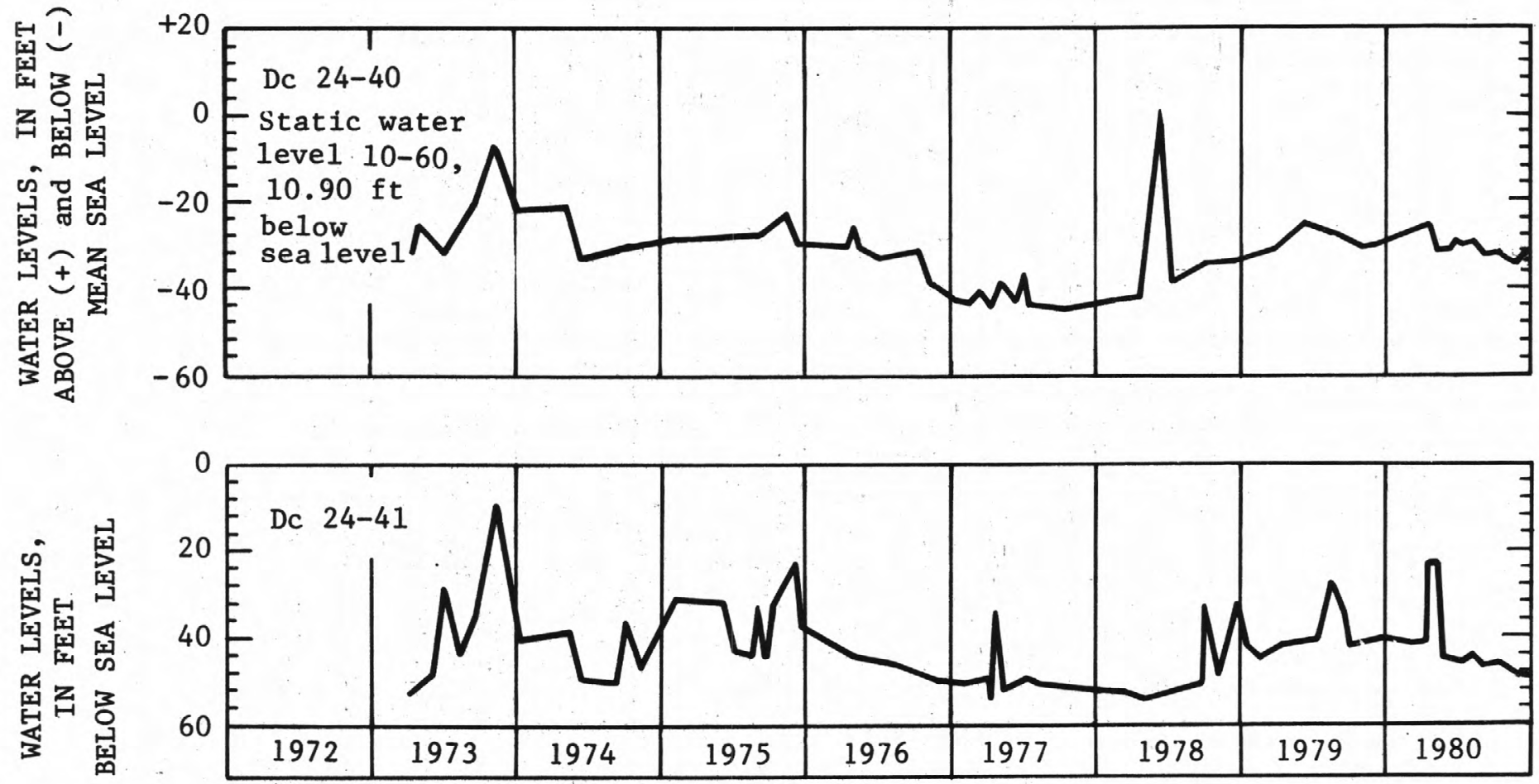

FIGURE 45.--Llangollen Estates. Water levels in Dc24-40 and Dc24-41, 1973-80. 

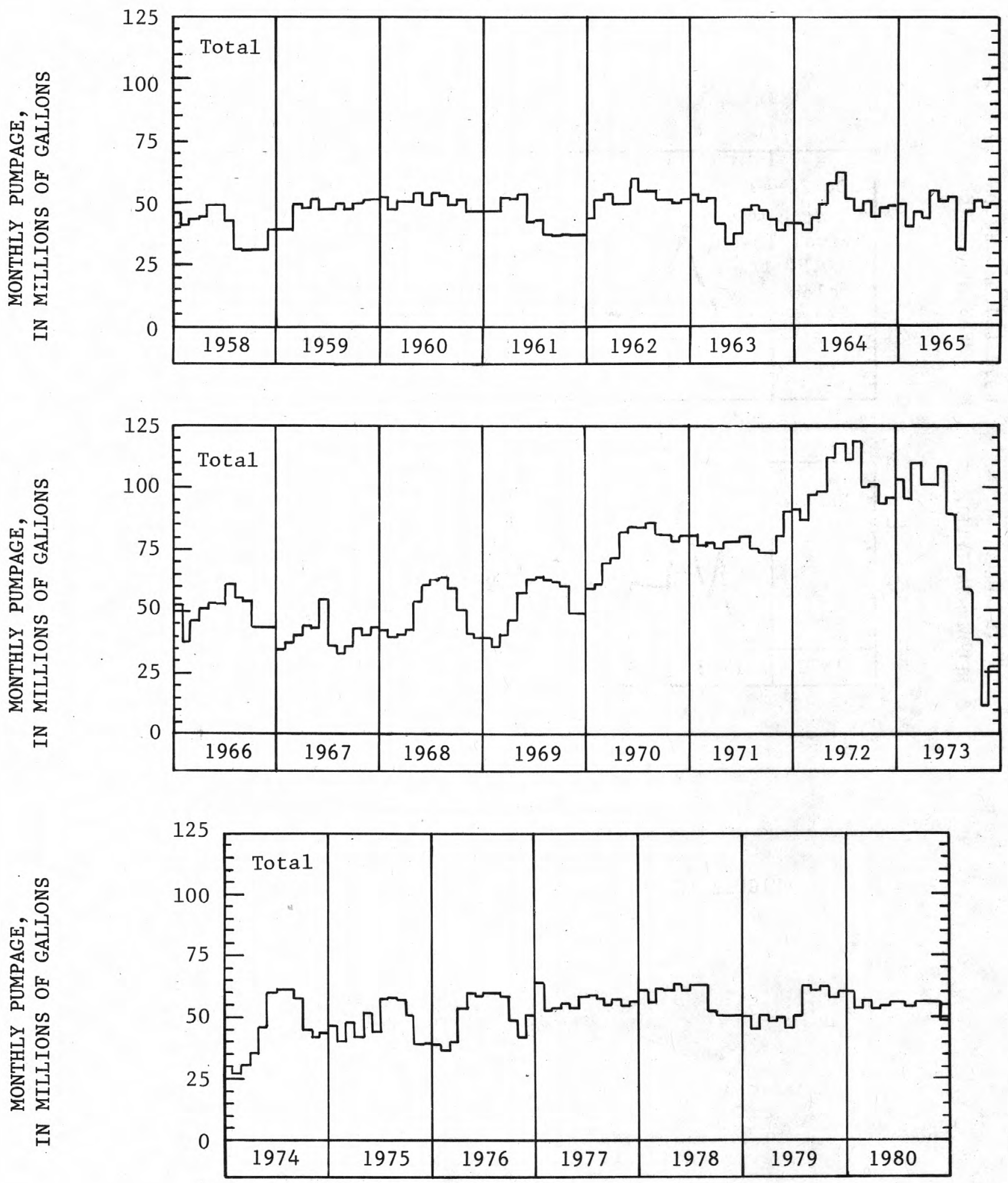

FIGURE 46.--Llangollen Estates. Total monthly pumpage from we11-field, 1958-80. 
MIDVALE

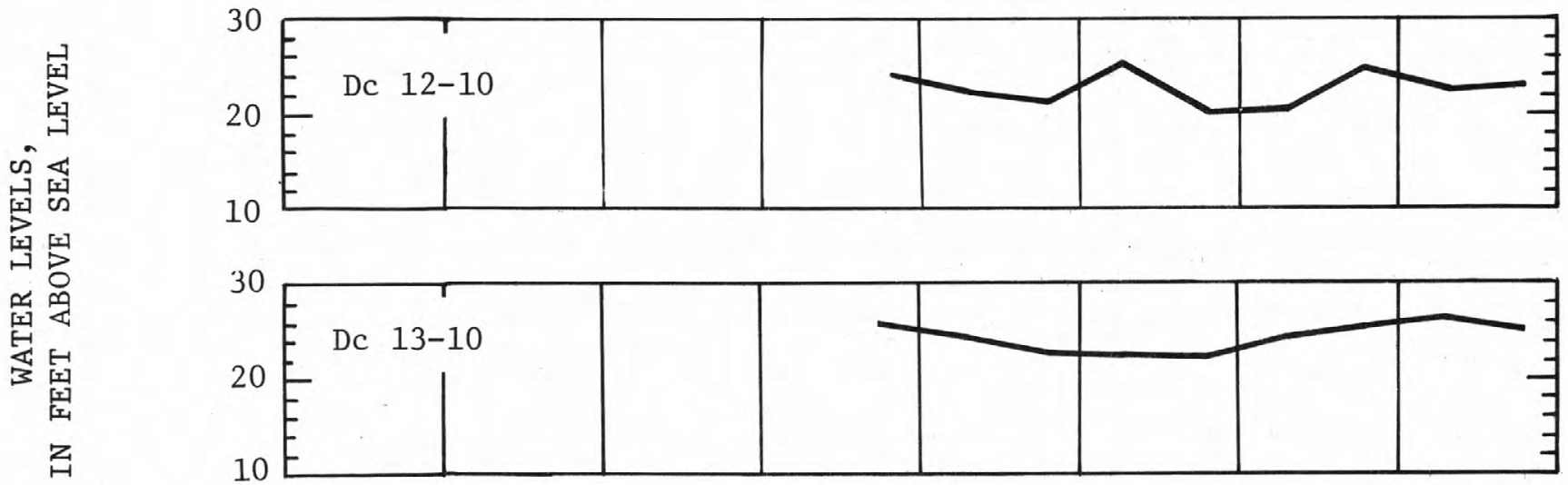

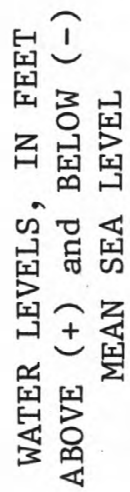
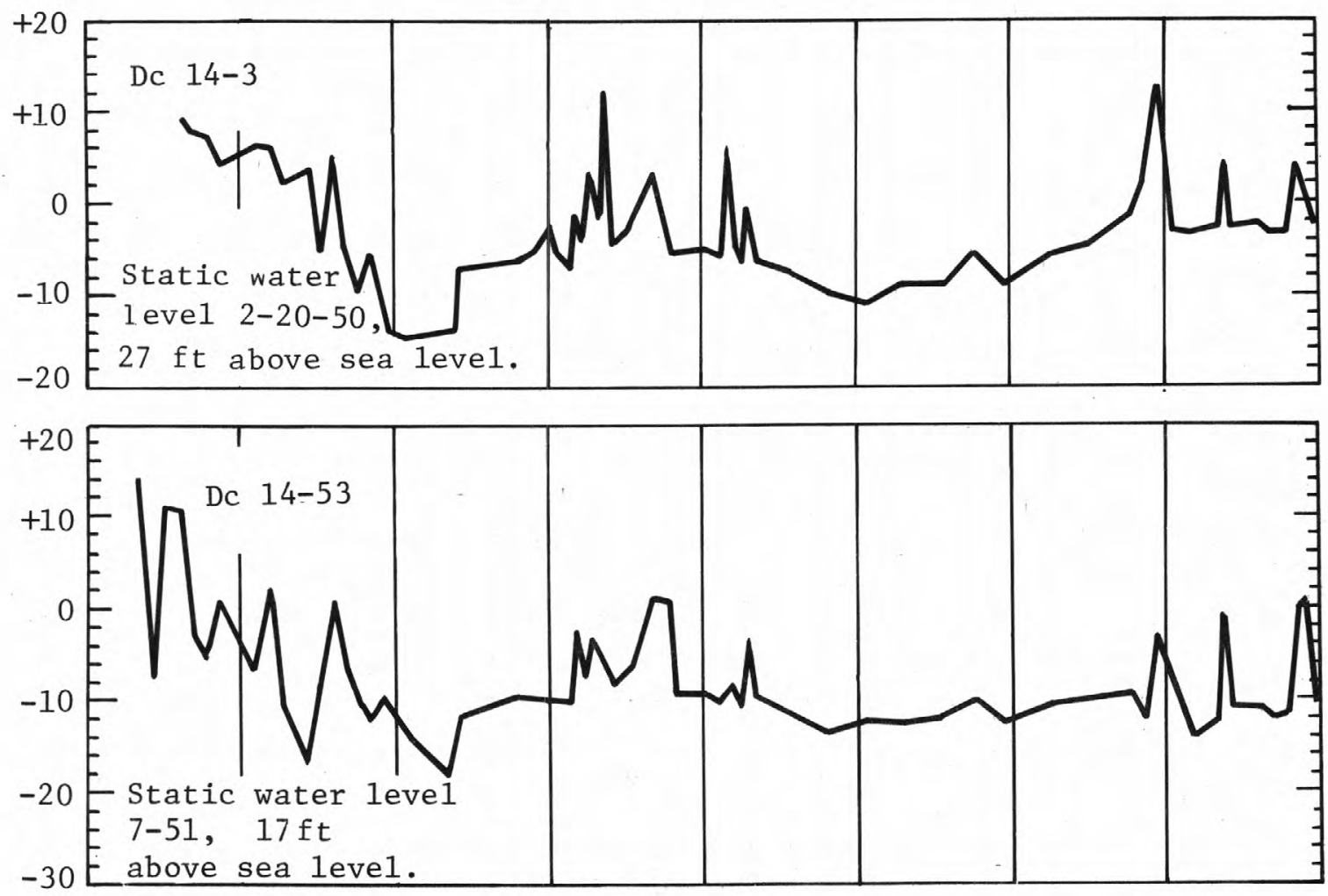

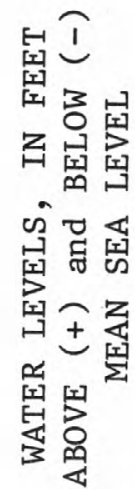

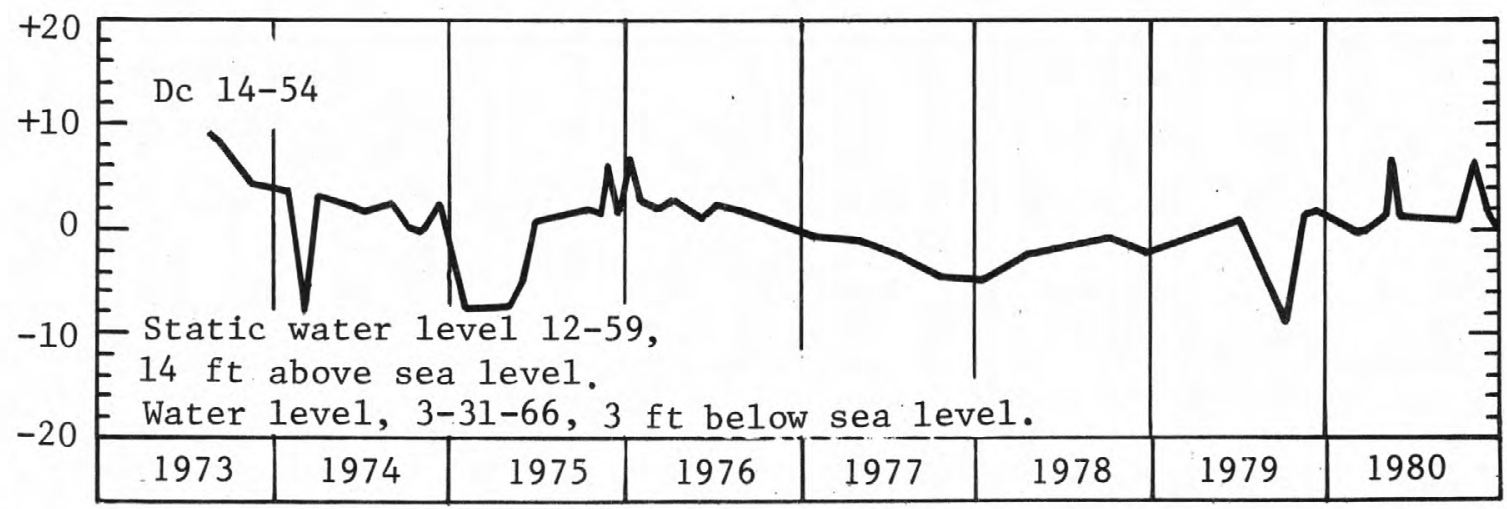

FIGURE 47.--Midvale. Water leve1s in Dc12-10 and Dc13-10,1976-80, and Dc14-3, Dc14-53, and Dc14-54, 1973-80. 


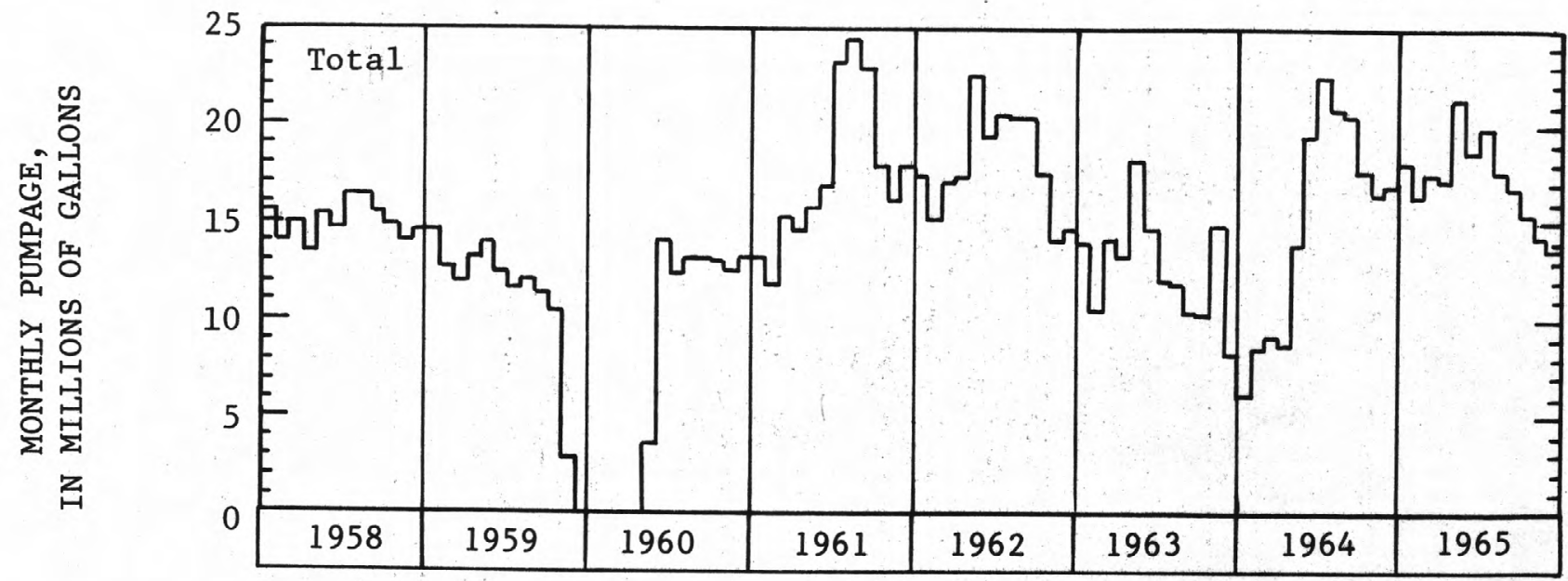

资曷

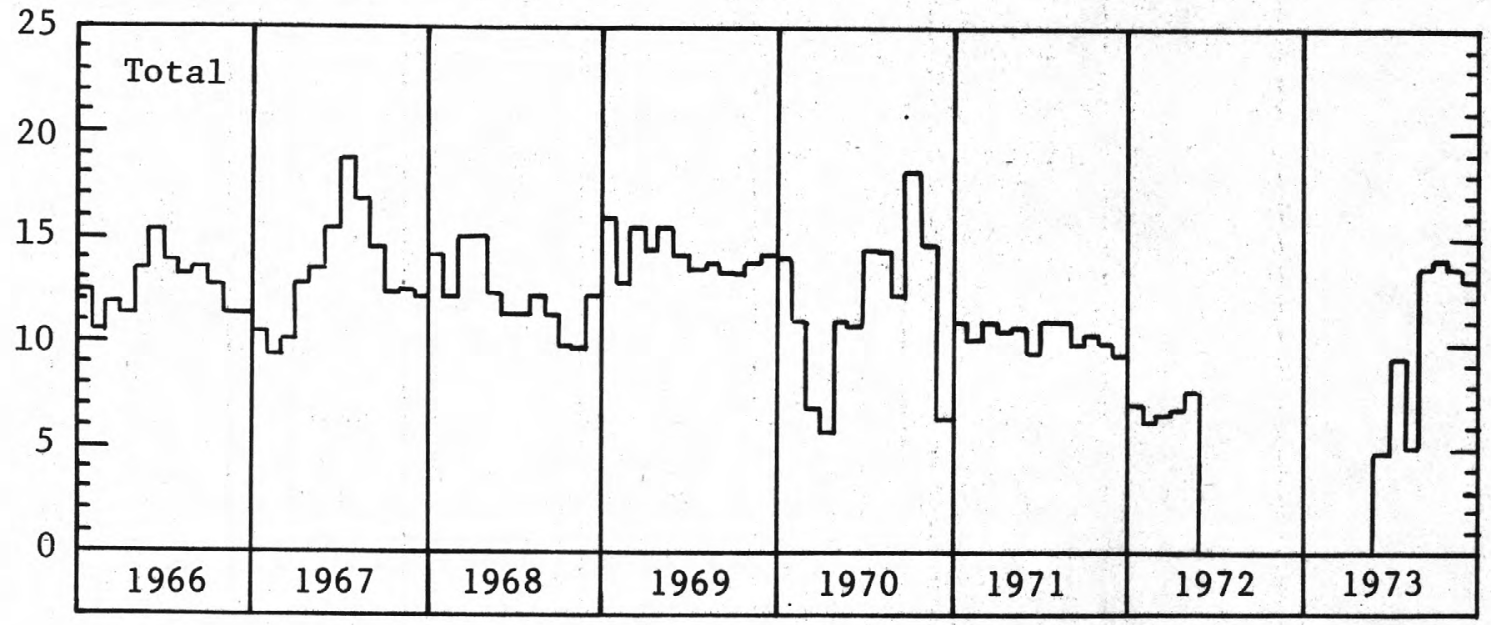

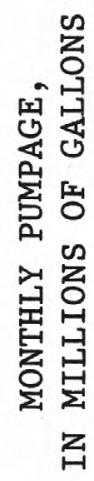

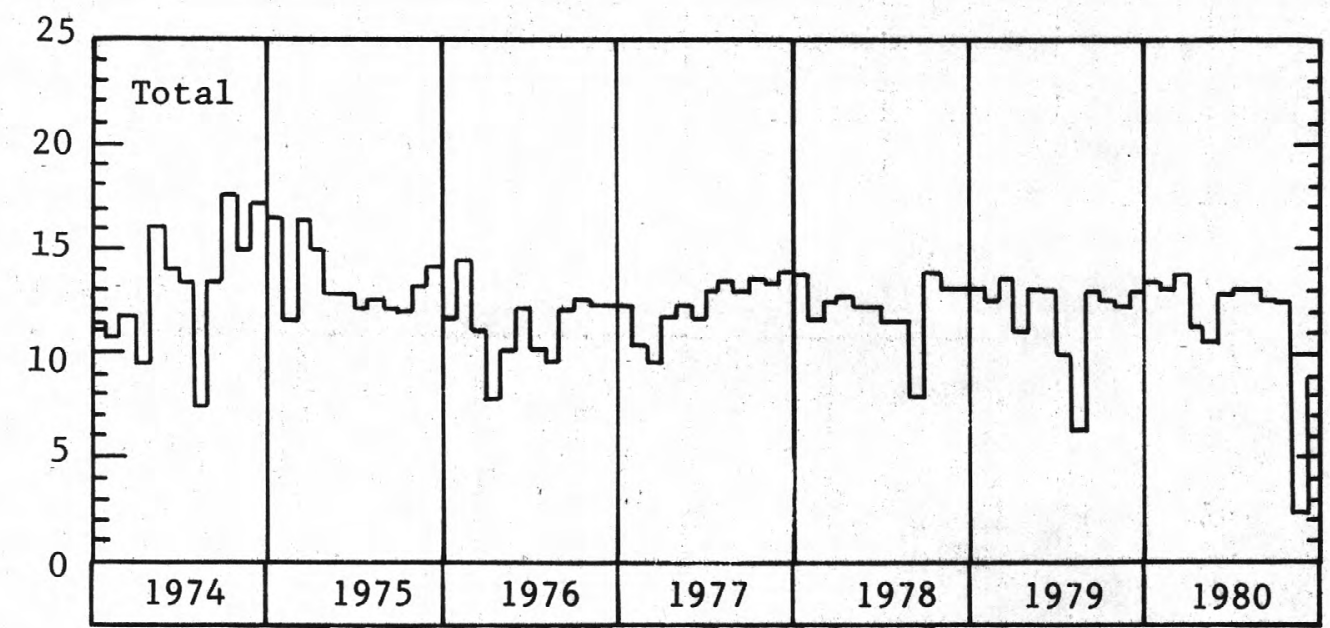

FIGURE 48.--Midvale. Total monthly pumpage from well field, 1958-80. 
NATIONAL GUARD RIFLE RANGE

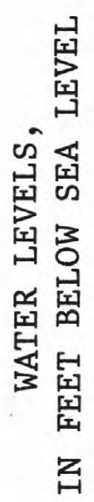

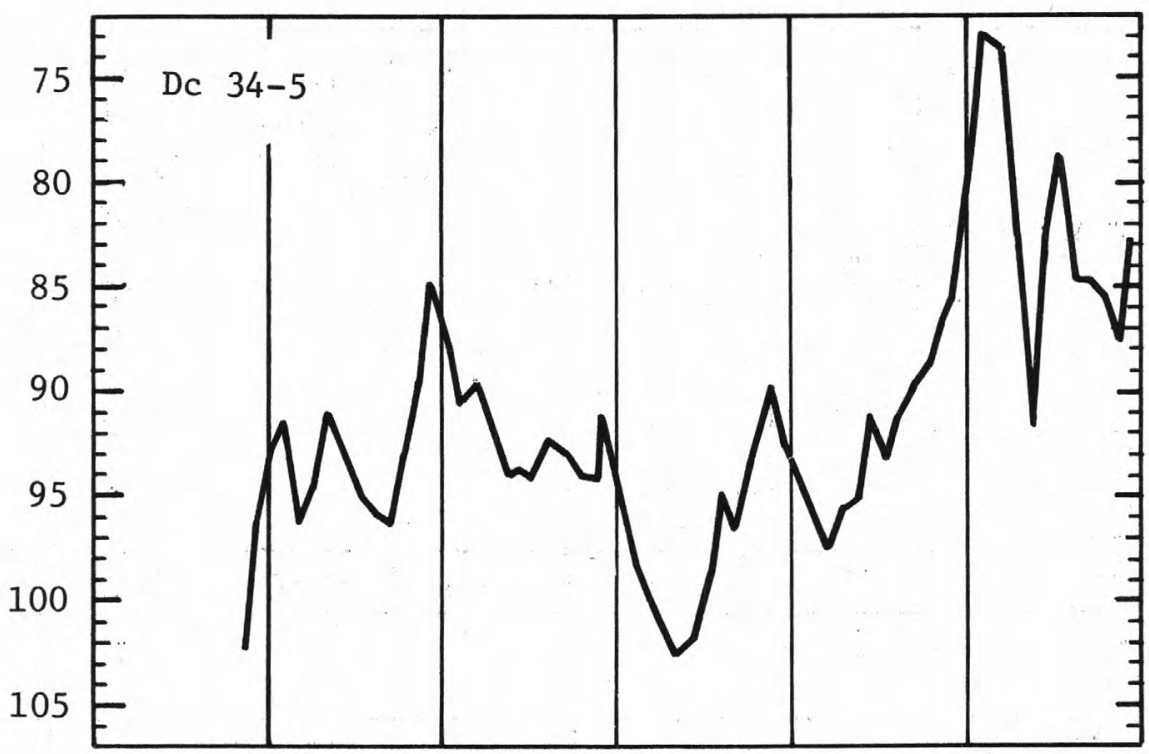

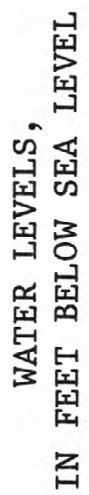

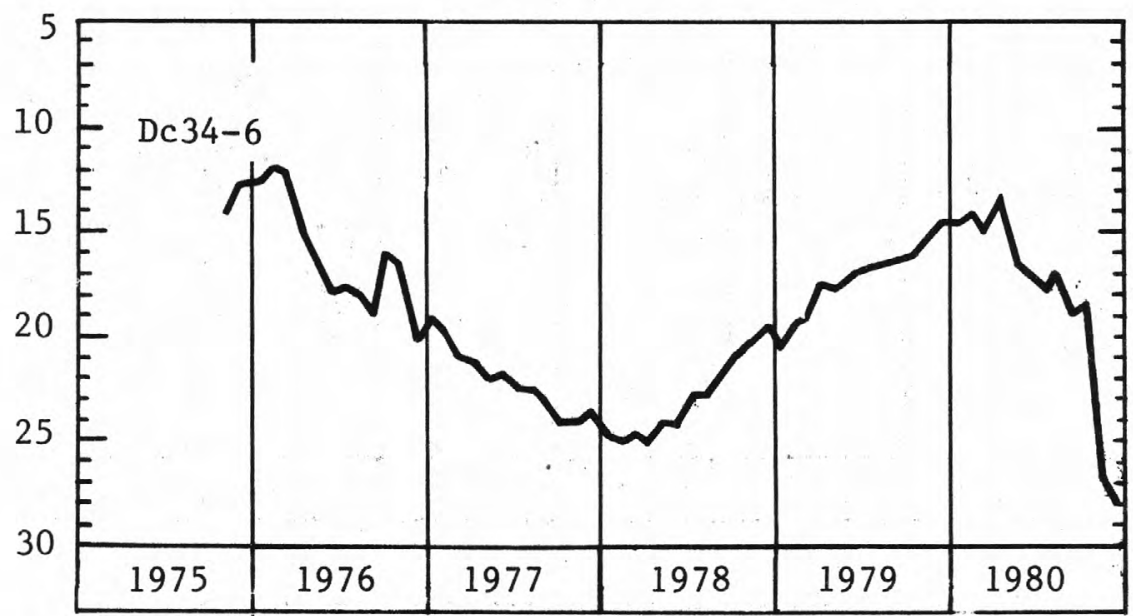

FIGURE 49.-- National Guard rifle range. Water levels in Dc34-5 and Dc34-6, 1975-1980.

点是

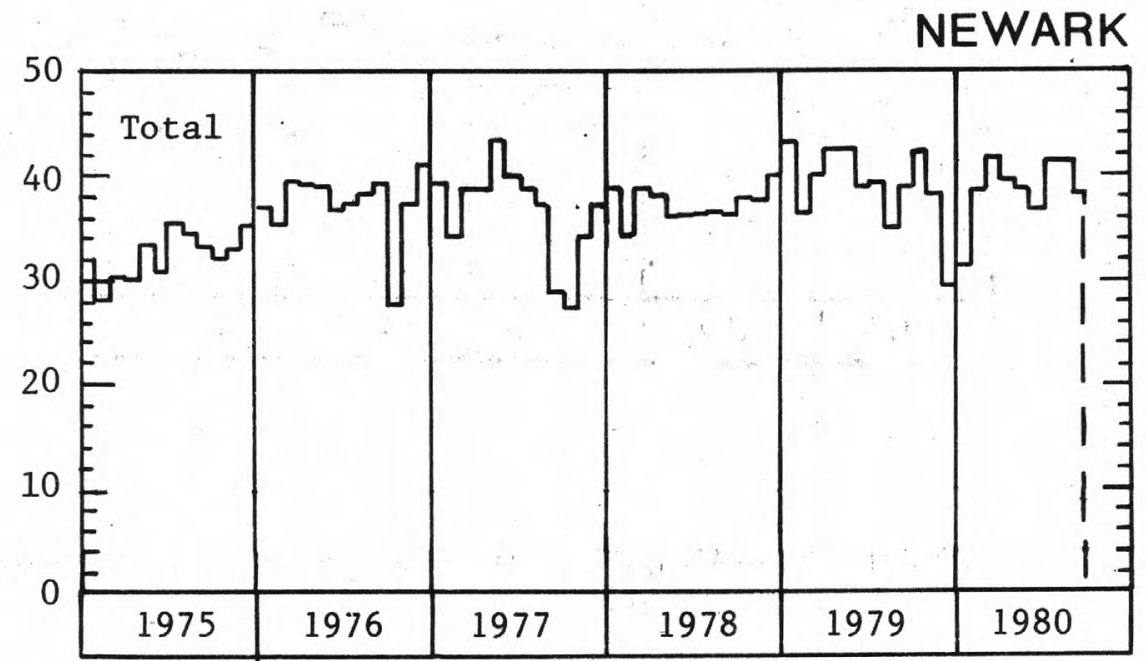

FIGURE 50.--Newark. Total month1y pumpage from well field, 1975-80. 

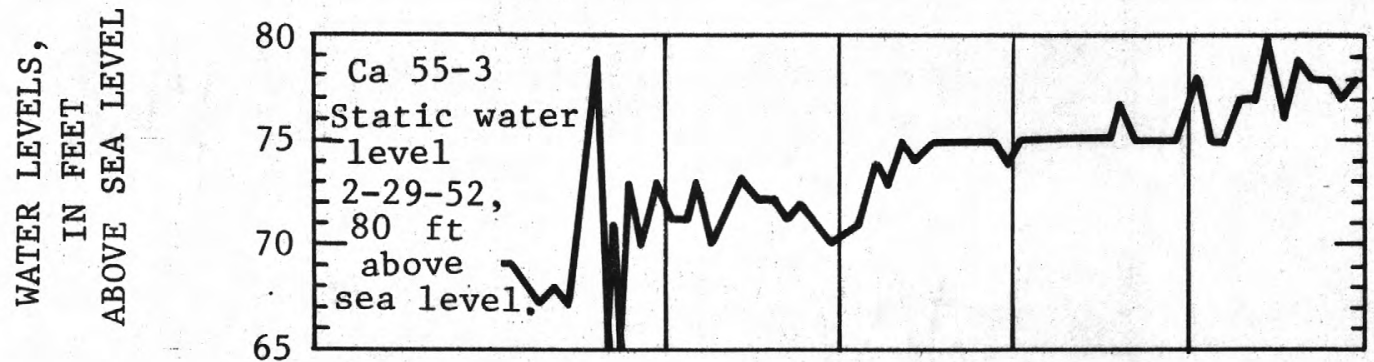

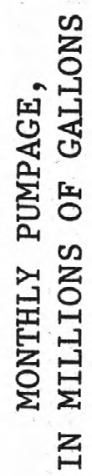

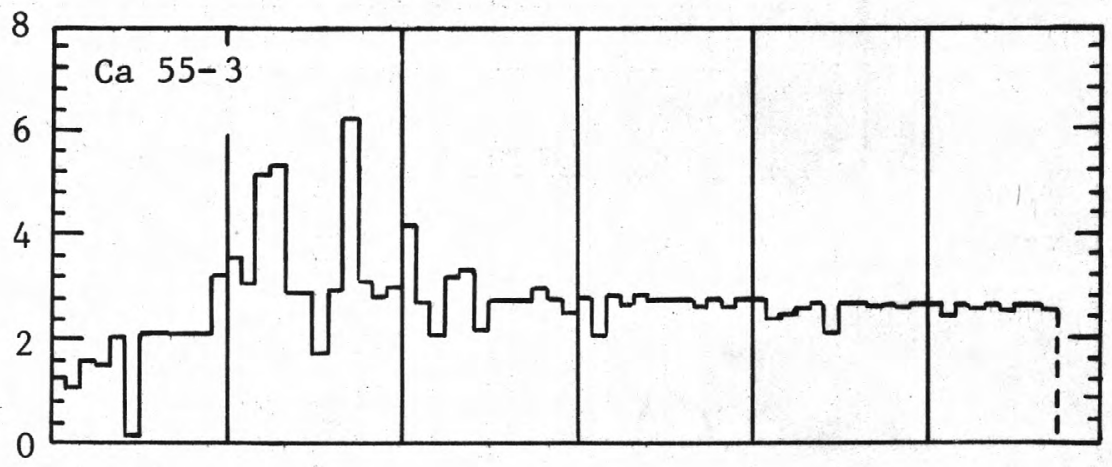

手

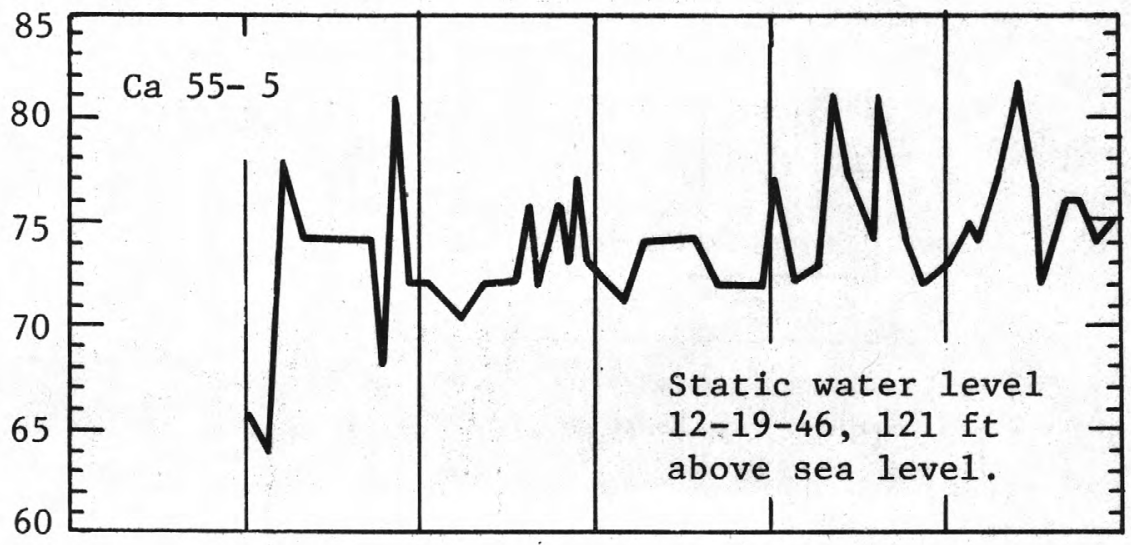

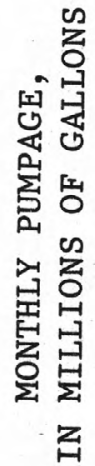

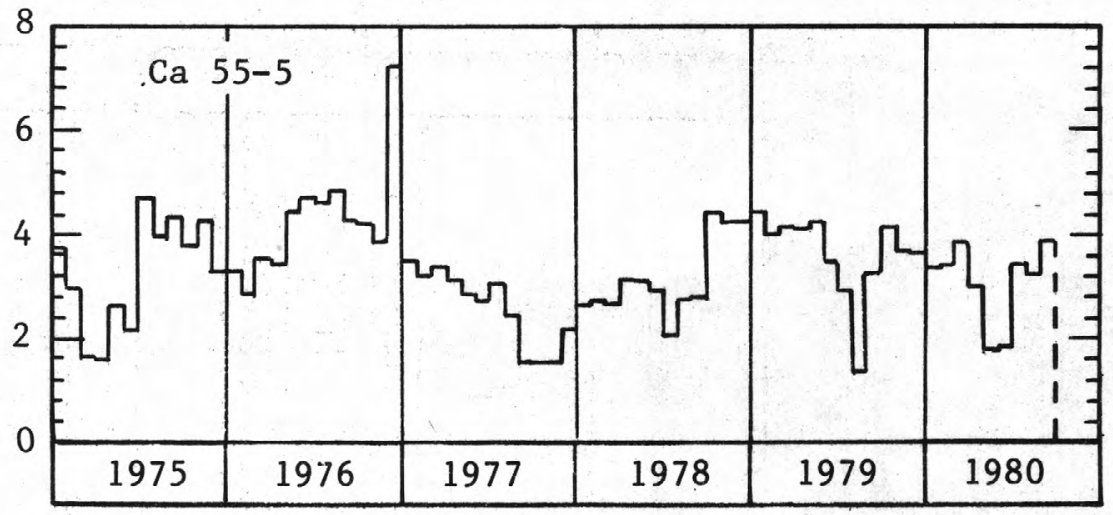

FIGURE 51.--Newark. Monthly pumpage from Ca55-3 and Ca55-5, 1975-80. Water levels in Ca55-3 and Ca55-5, $1976-80$. 

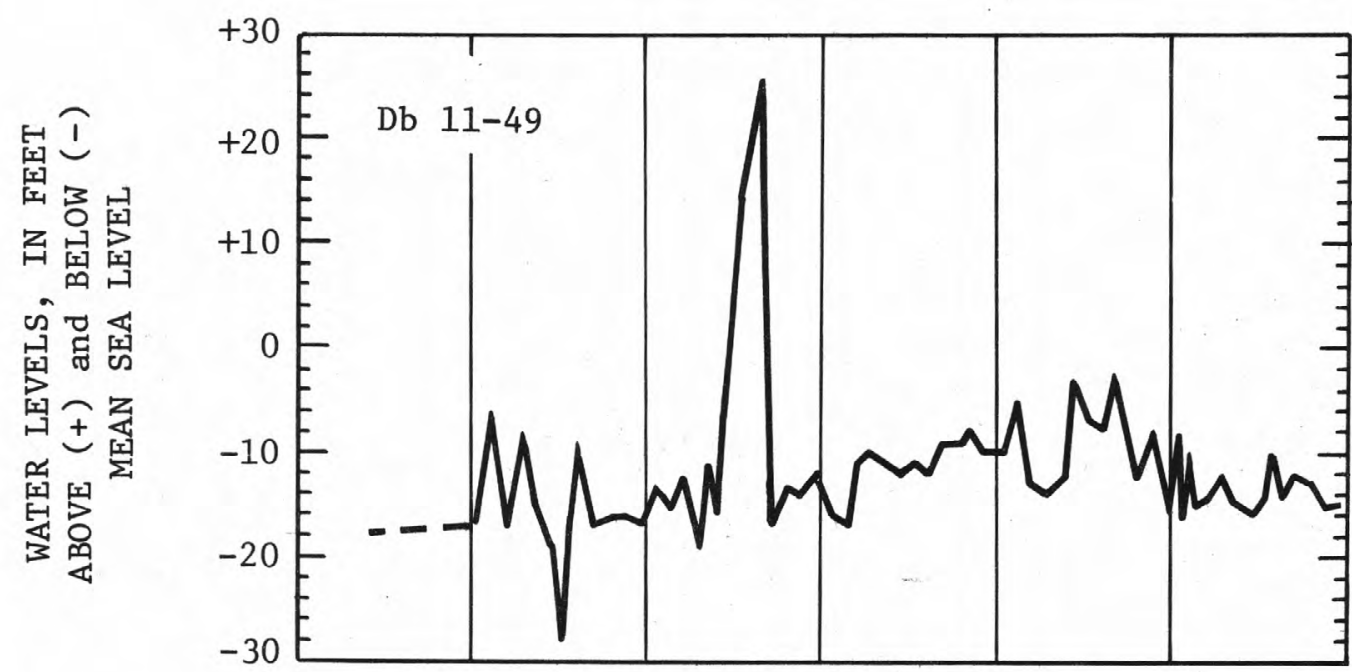

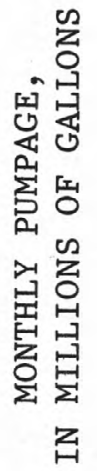
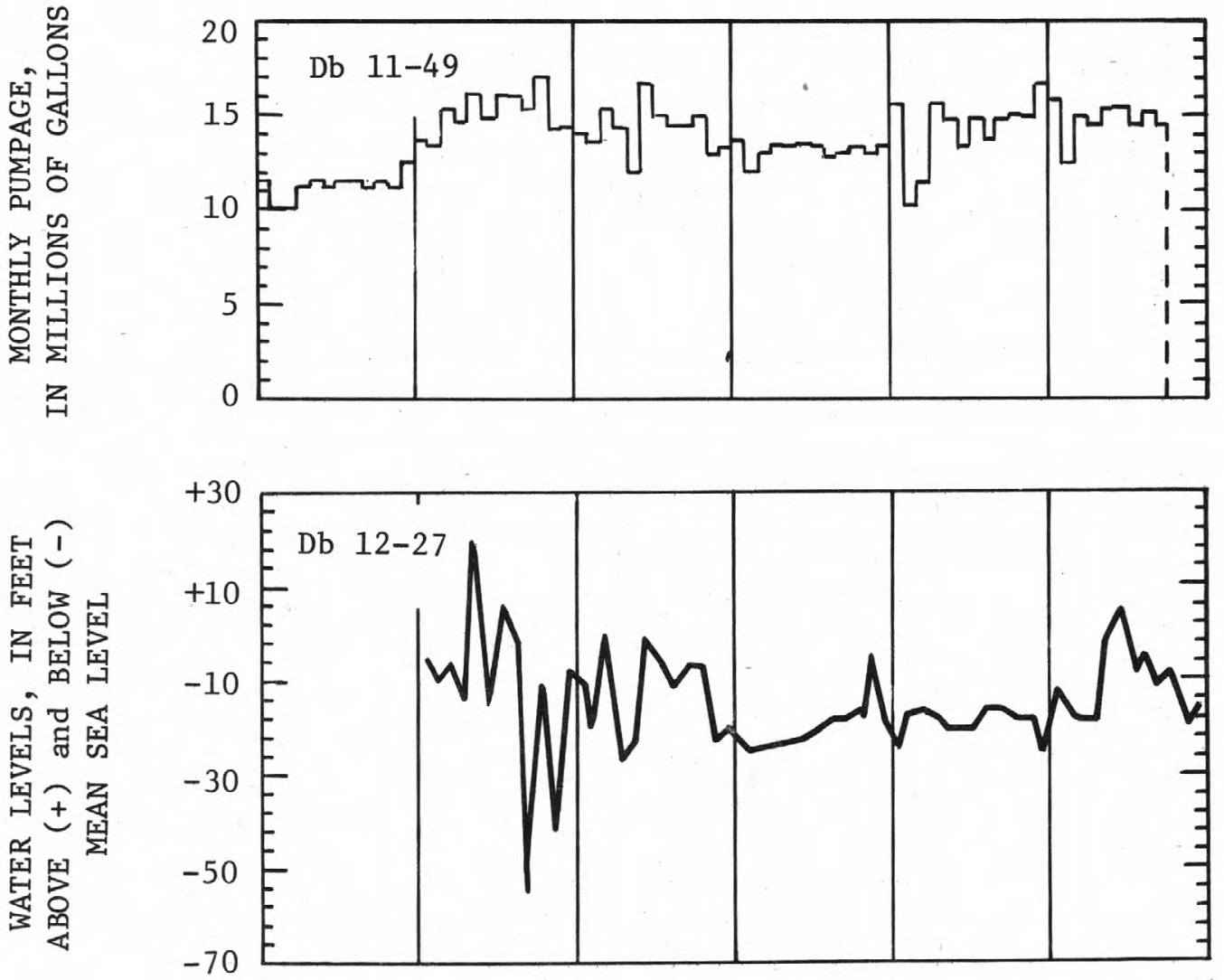

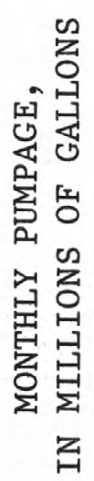

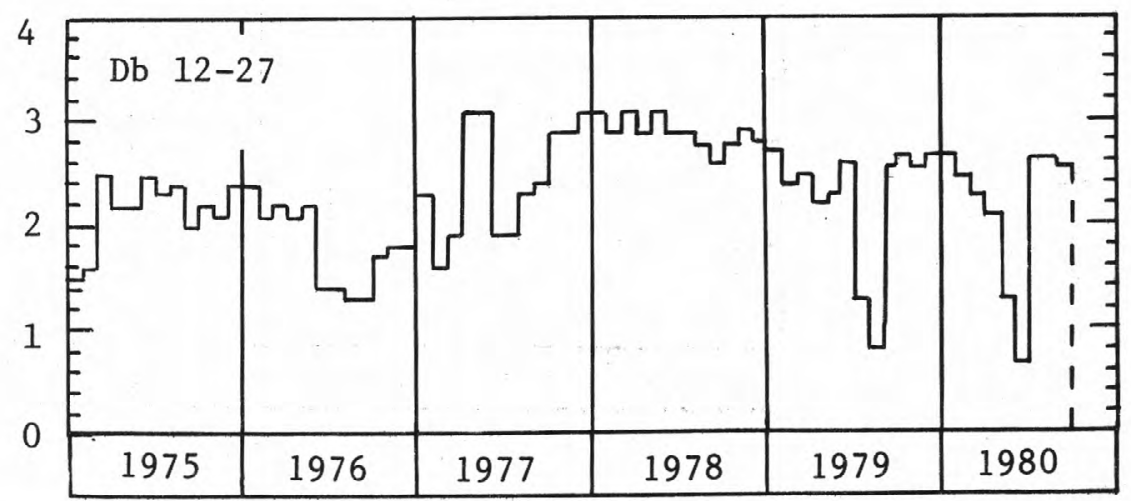

FIGURE 52.--Newark. Month1y pumpage from Db11-49 and Db12-27, 1975-80. Water levels in Db11-49, 1975-80. and $\mathrm{Db} 12-27,1976-80$. 


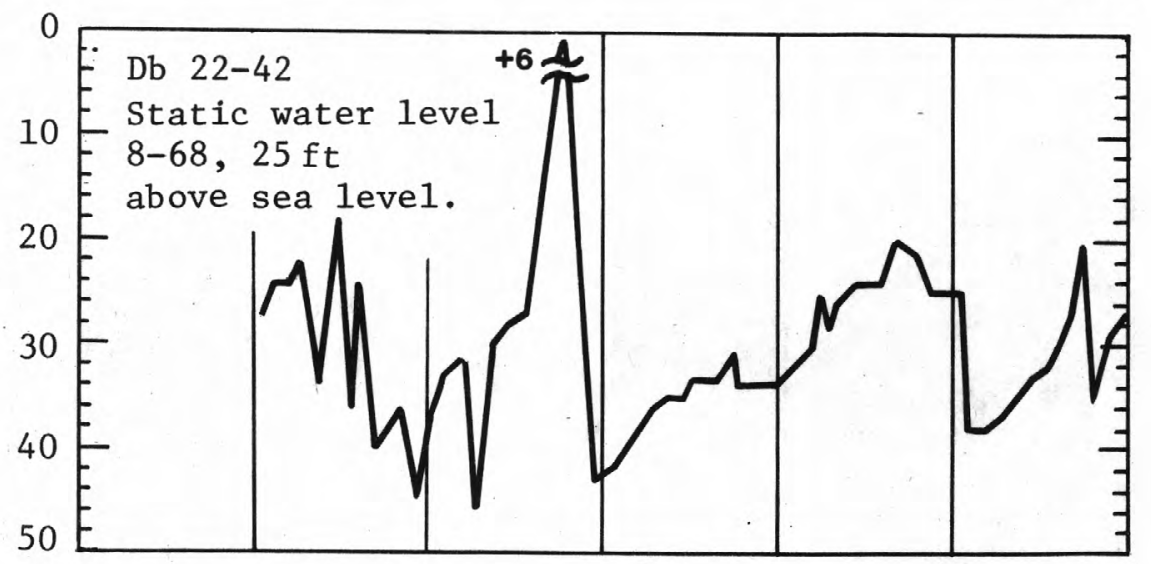

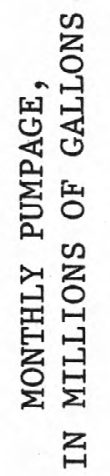

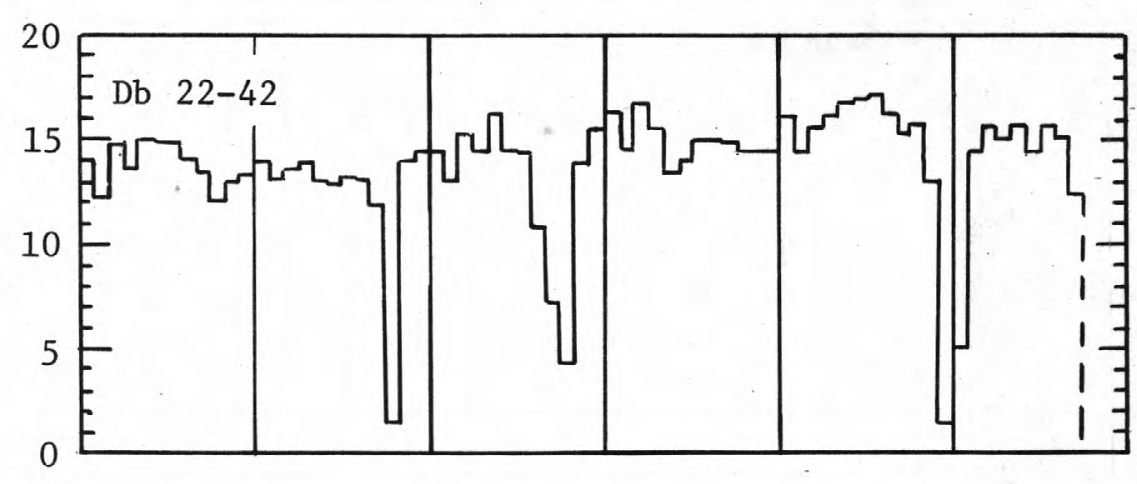

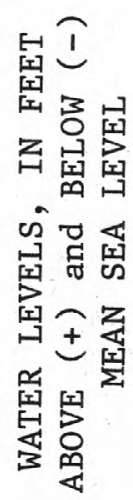

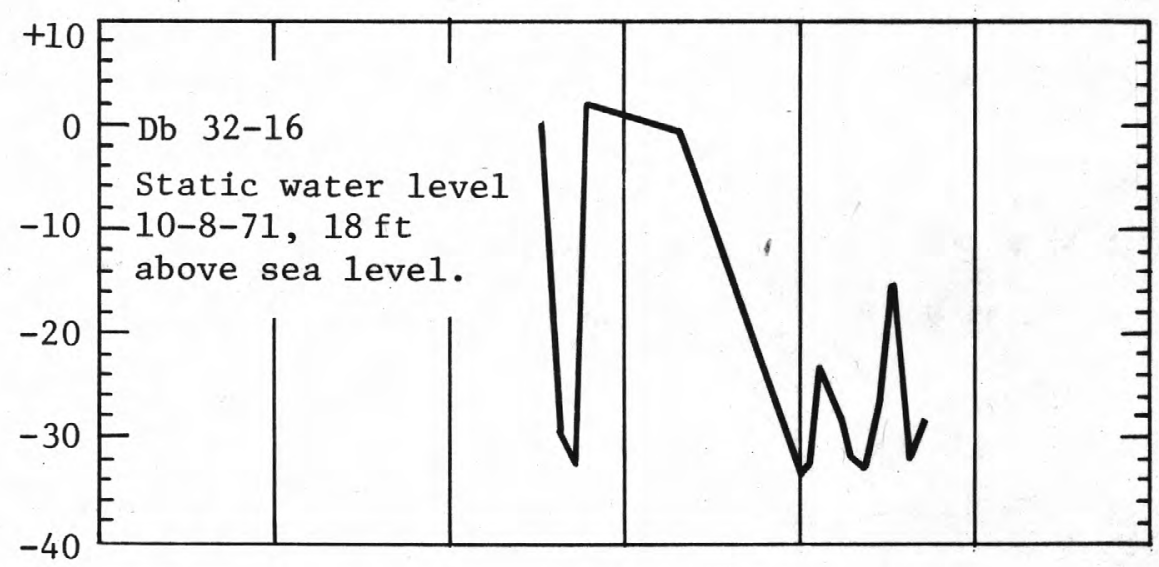

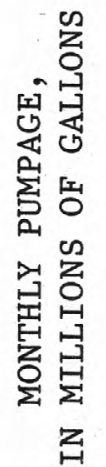

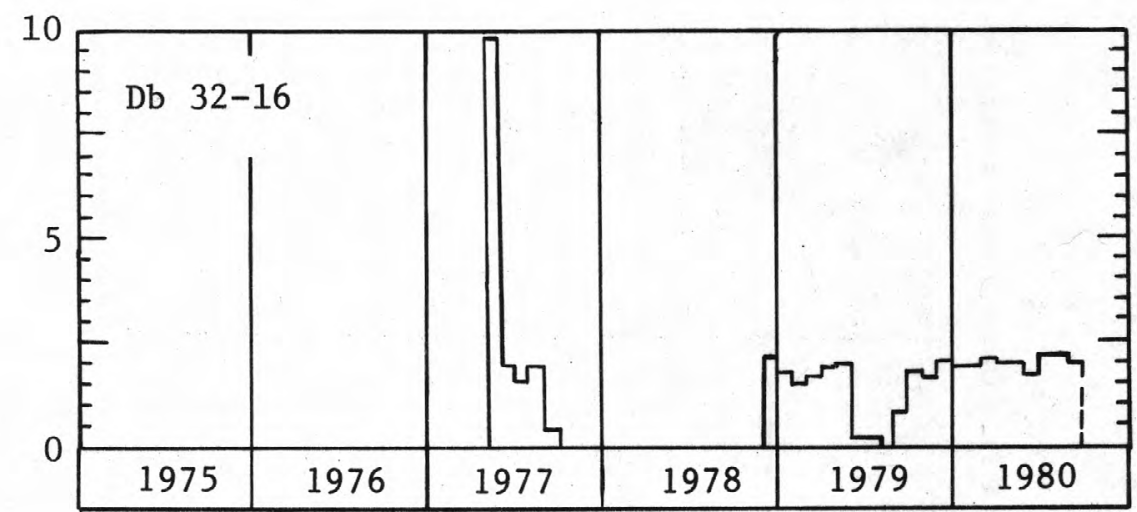

FIGURE 53.--Newark. Month1y pumpage from Db22-42, 1975-80, and $\mathrm{Db} 32-16,1977-80$. Water levels in $\mathrm{Db} 22-42$, 1976-80, and Db32-16, 1977-79. 

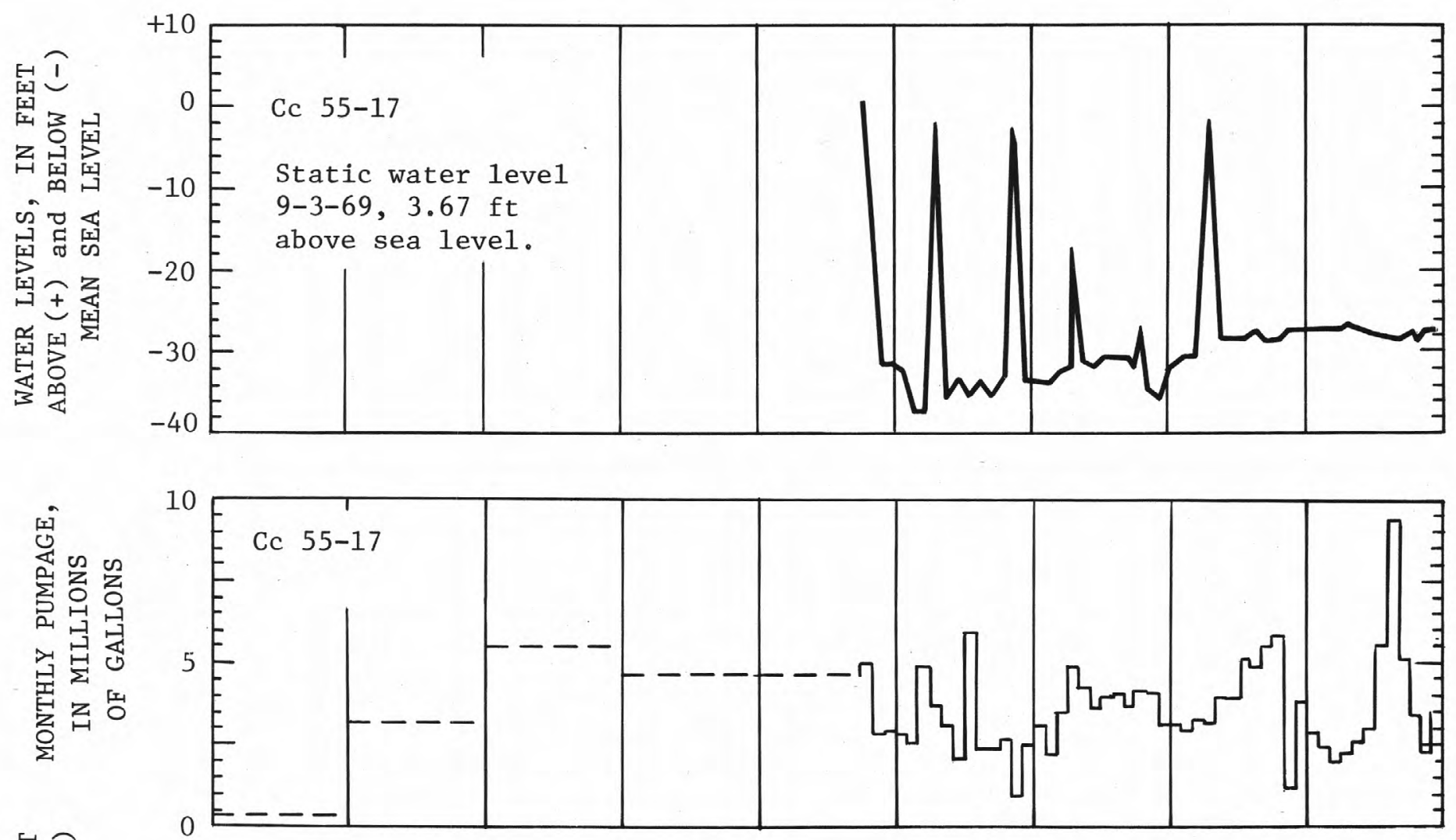

寽

䛼䎡
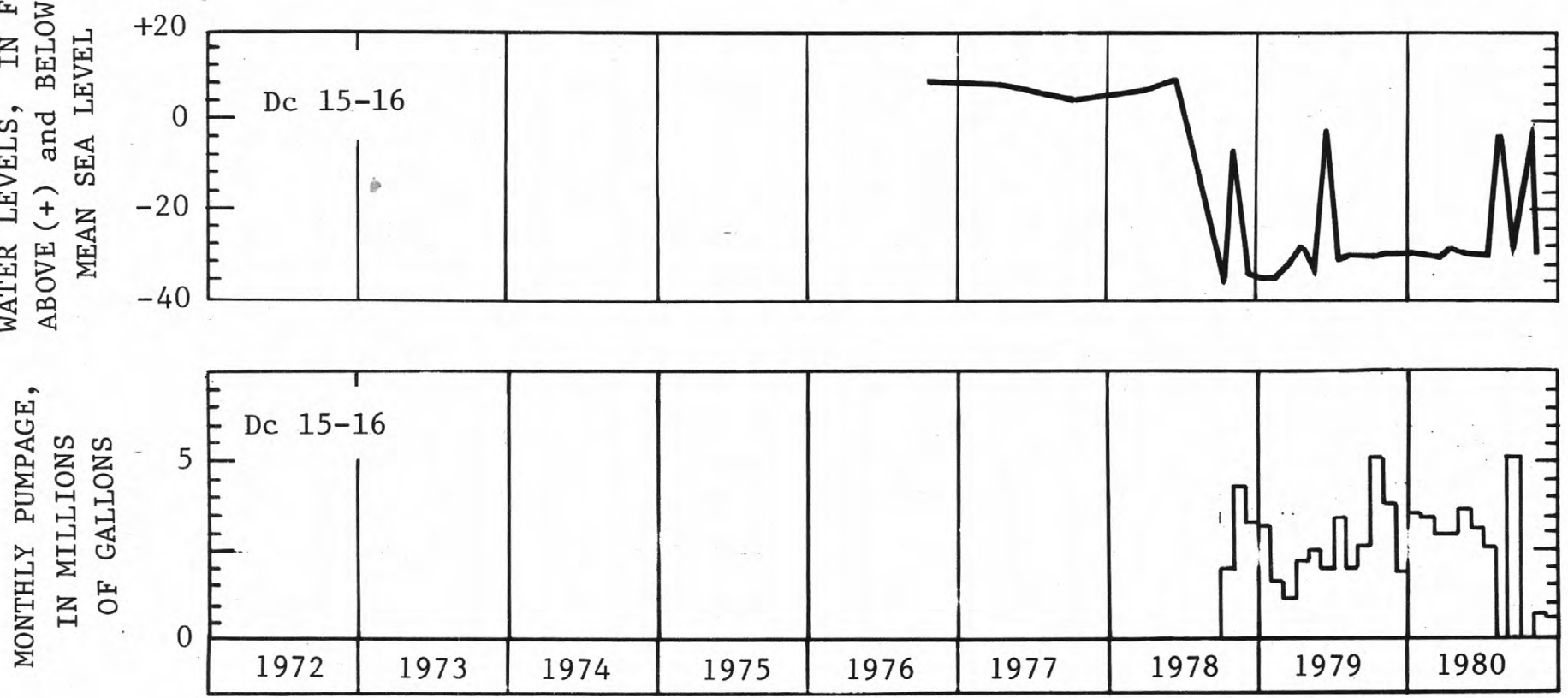

FIGURE 54.--New Castle. Monthly pumpage from Cc55-17, 1972- 80, and Dc15-16, 1978-80. Water levels in Cc55-17 and Dc15-16, 1976-80. 
NEW CASTLE

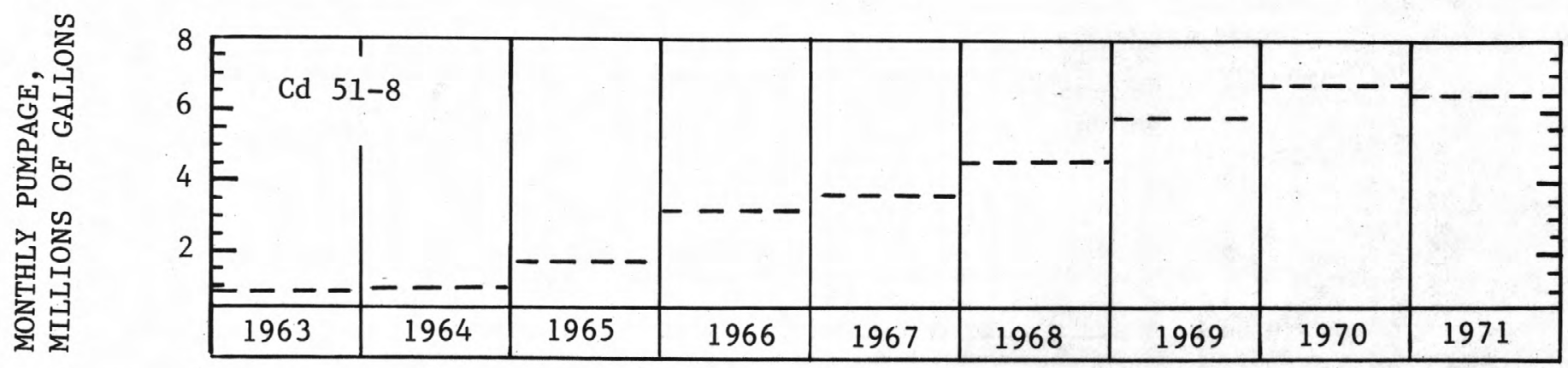

品
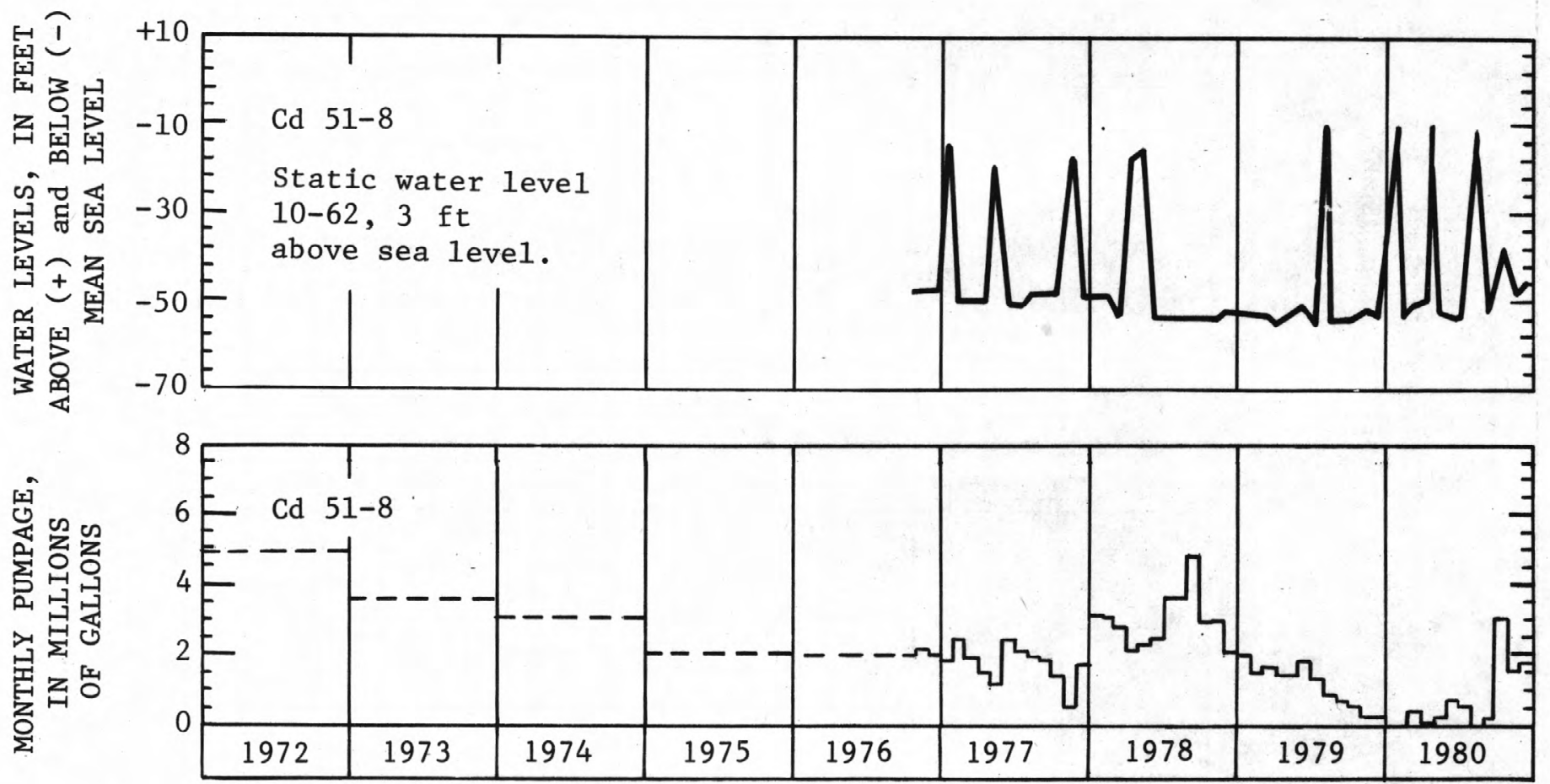

FIGURE 55.--New Castle. Monthly pumpage from Cd51-8, 1963-80. Water levels in Cd51-8, 1976-80. 
NEW CASTLE
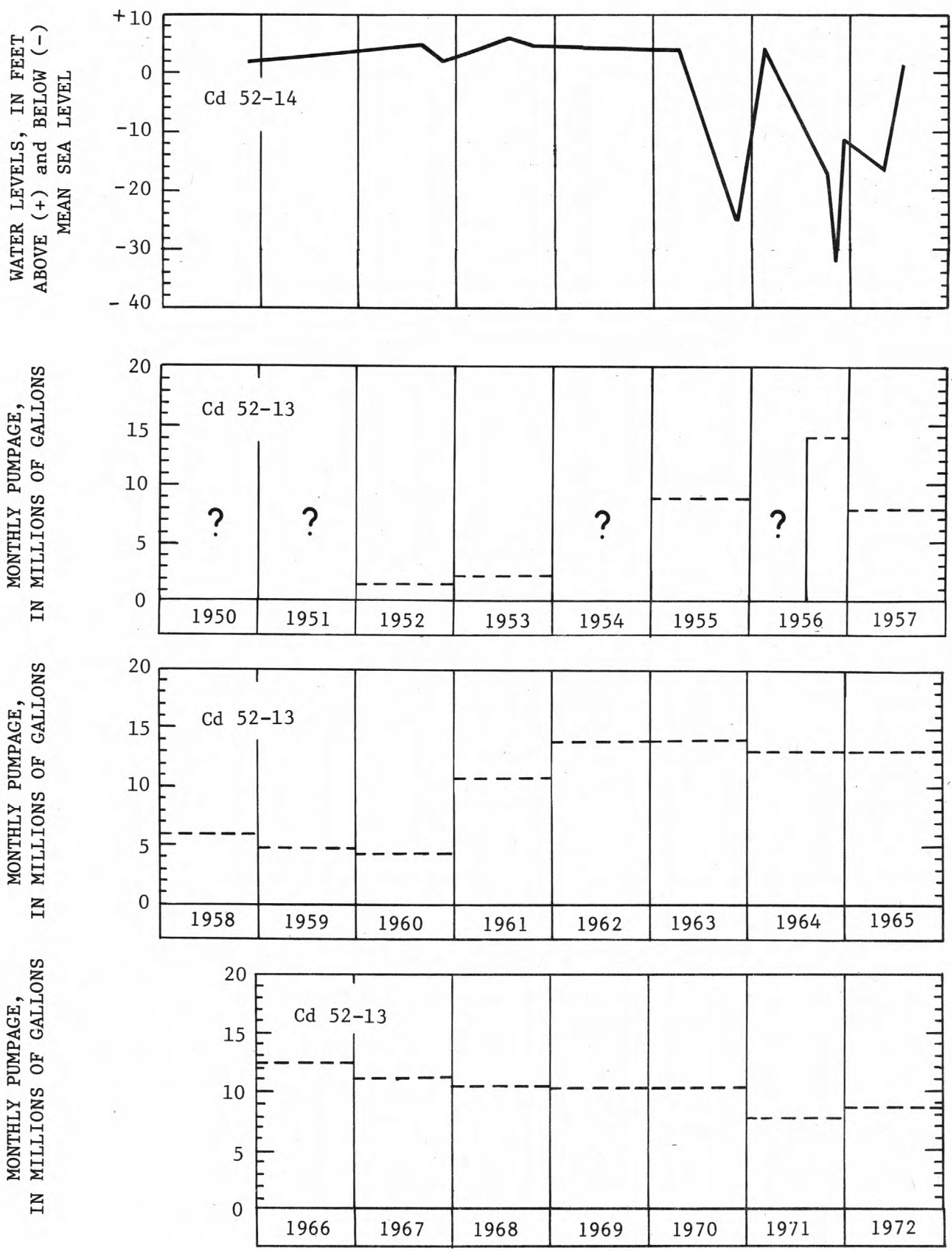

FIGURE 56.--New Castle. Monthly pumpage from Cd52-13, 1952- 72. Water levels in Cd52-14, 1950- 57. 
NEW CASTLE
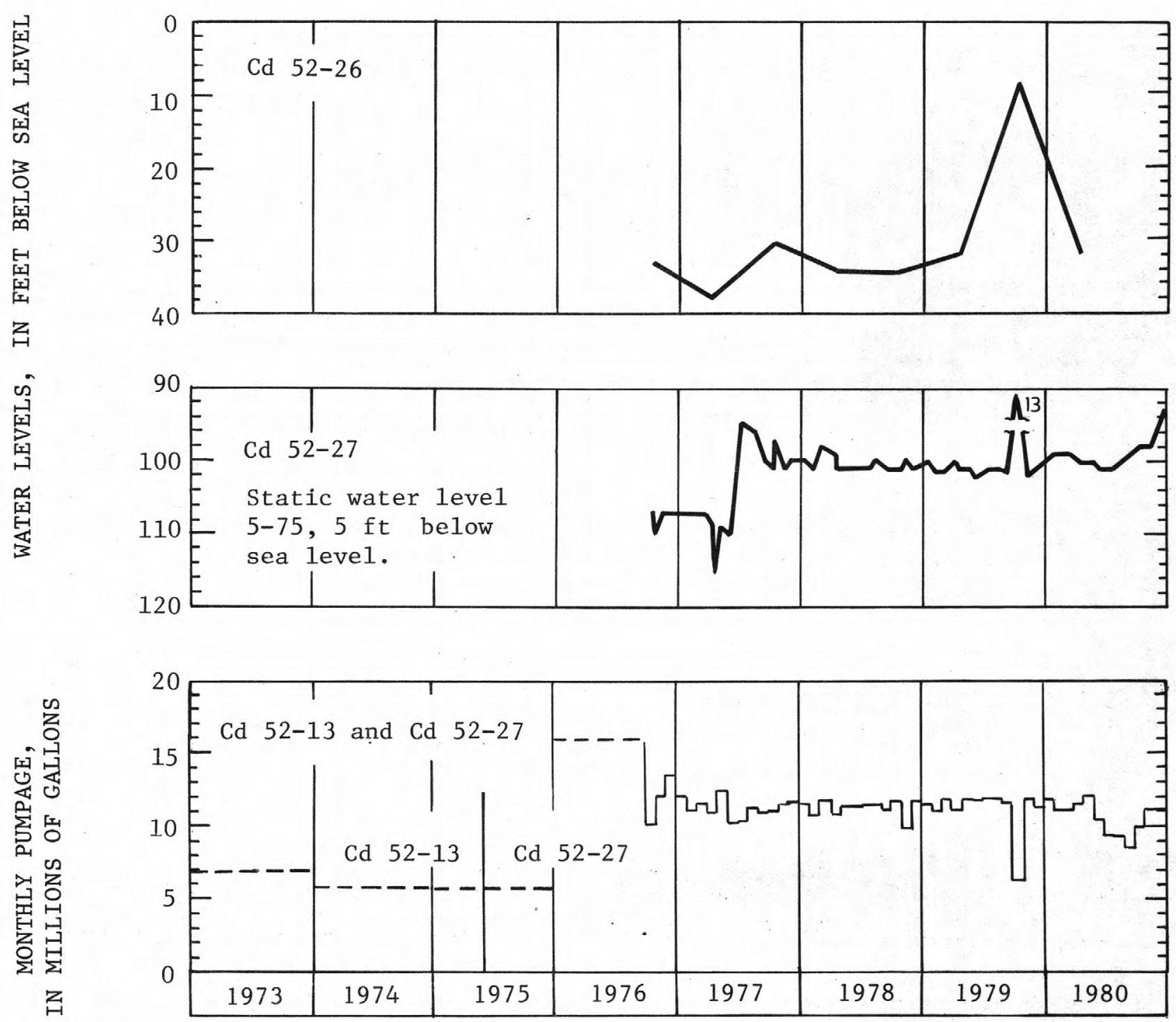

FIGURE 57.--New Castle. Monthly pumpage from Cd52-13, 1973-75, and $\mathrm{Cd} 52-27,1975-80$. Water levels in $\mathrm{Cd} 52-26$ and Cd52-27, 1976-80. 
NEW CASTLE
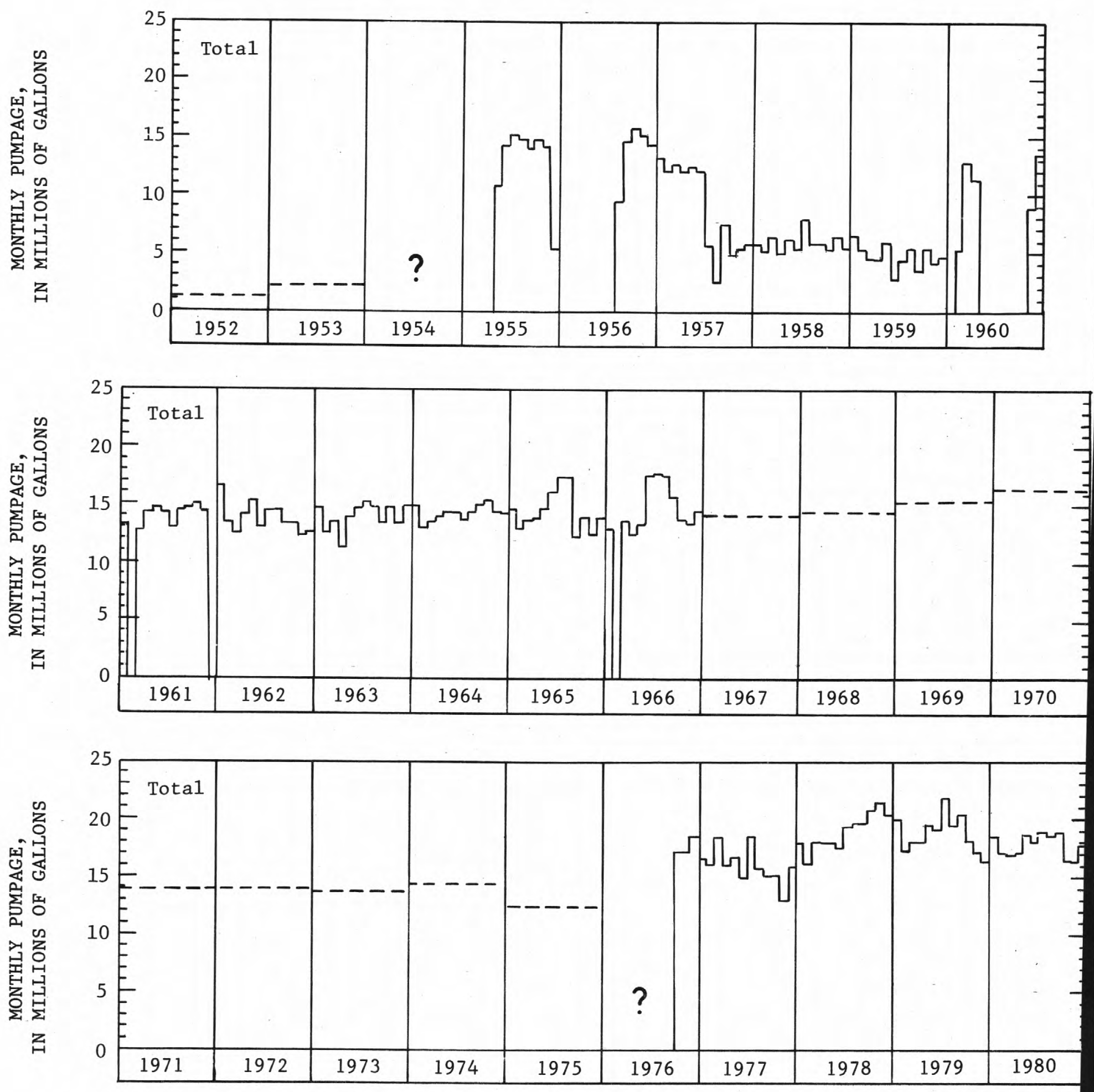

FIGURE 58.--New Castle. Total monthly pumpage from well field, 1952-80. 

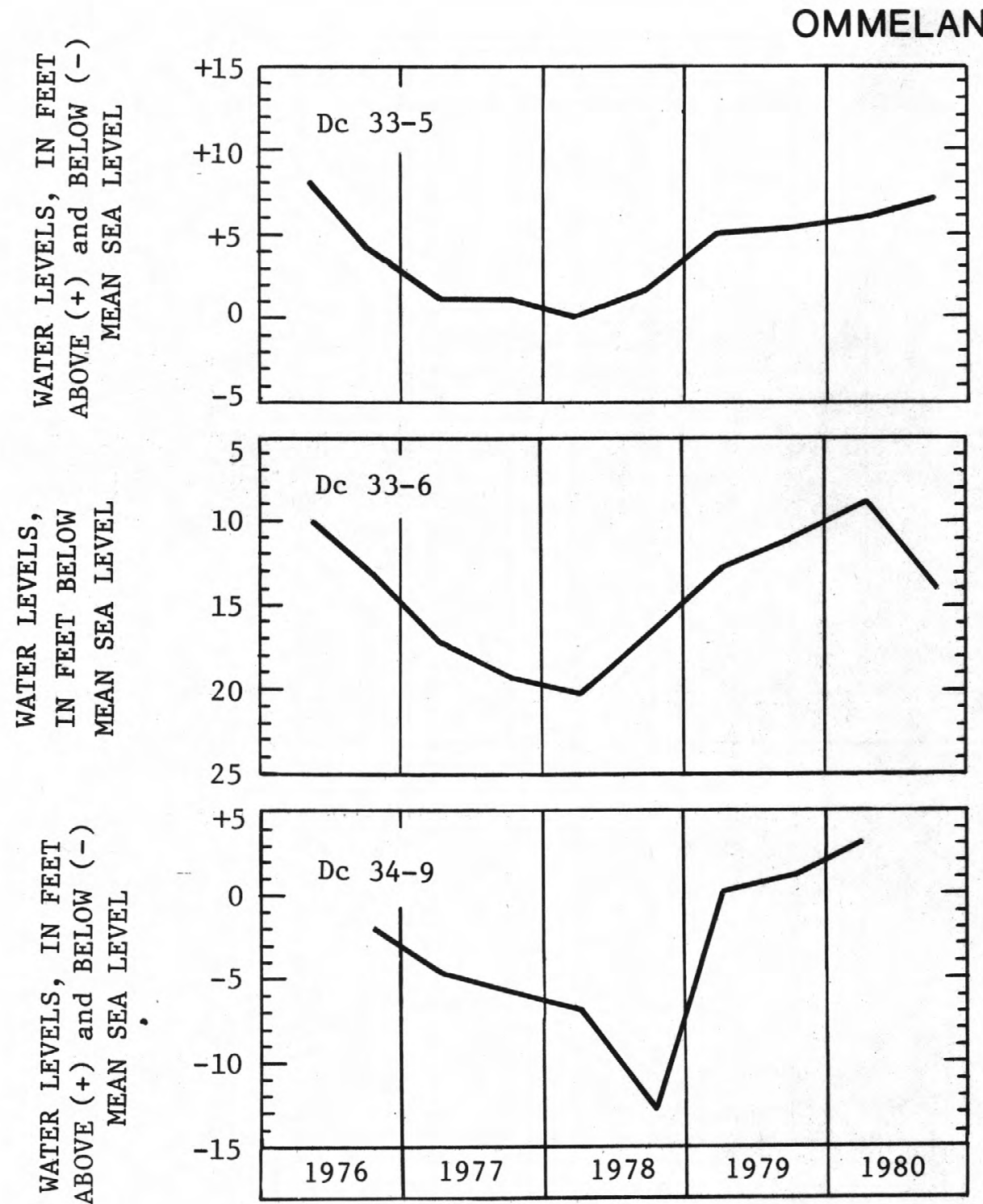

FIGURE 59.--Ommelanden Park. Water levels in Dc33-5, Dc33-6, and Dc34-9, 1976-80.

SMALLEY'S DAM

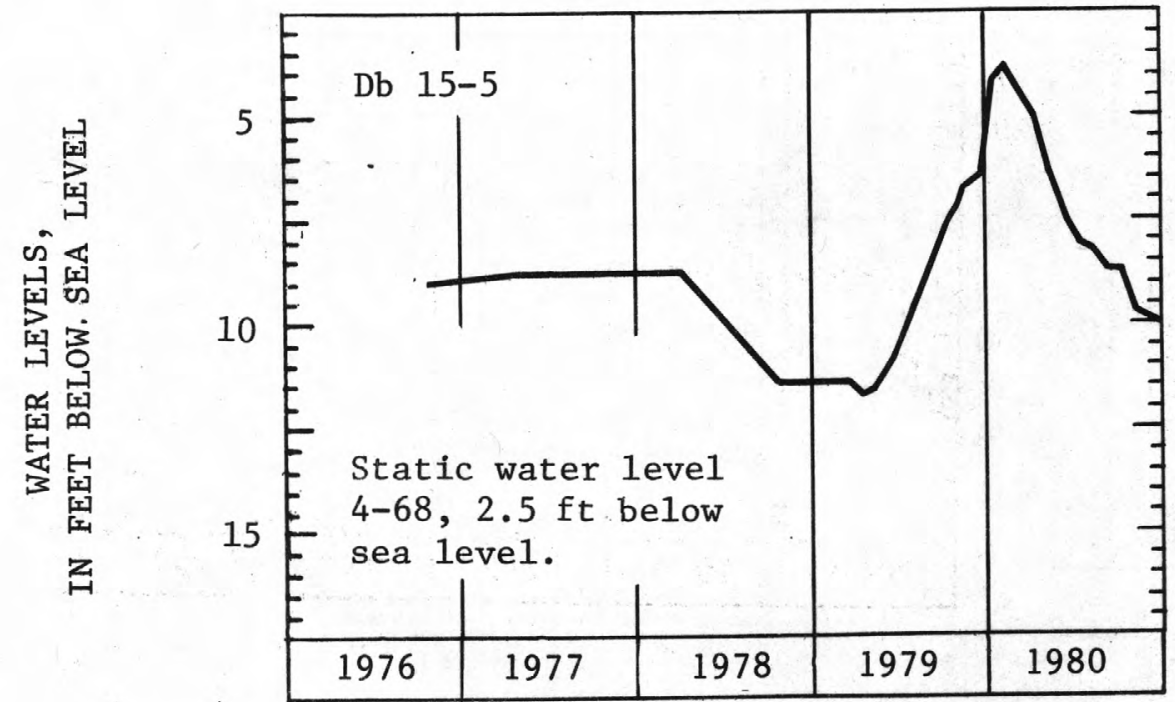

FIGURE 60.--Smalley's Dam. Water levels in Db15-5, 1976-80. 
TUXEDO PARK

告

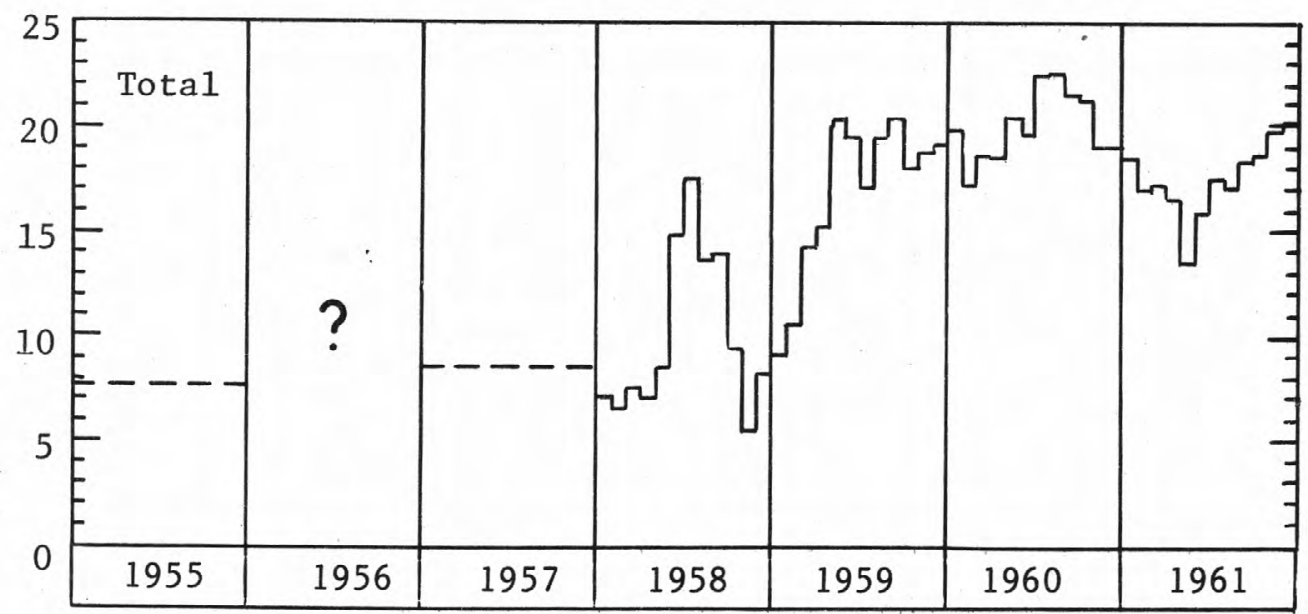

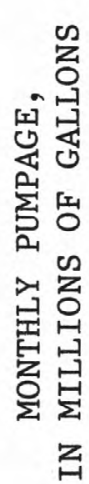
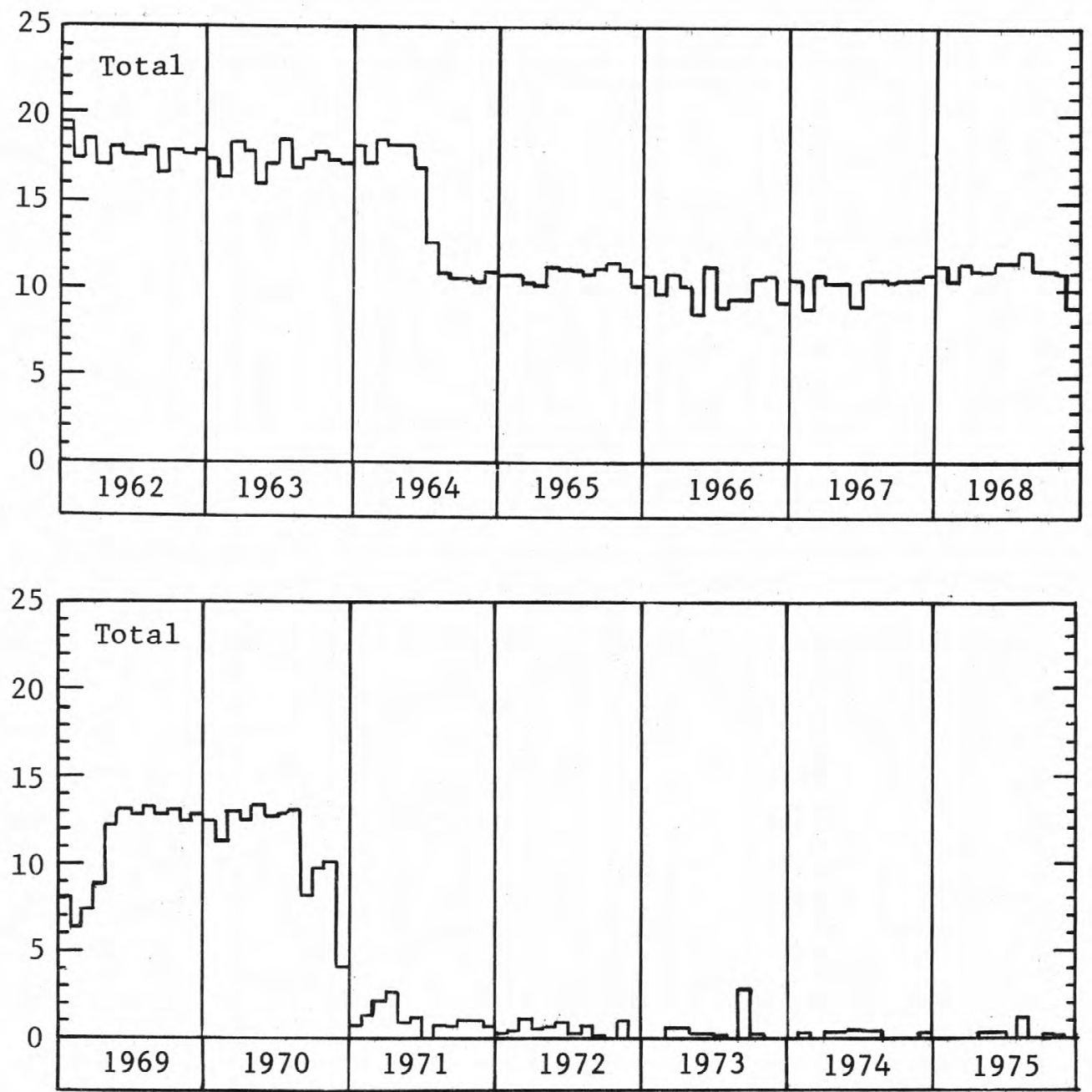

FIGURE 61.--Tuxedo Park. Total monthly pumpage from well field, 1955-75. 


\section{UNION CARBIDE}

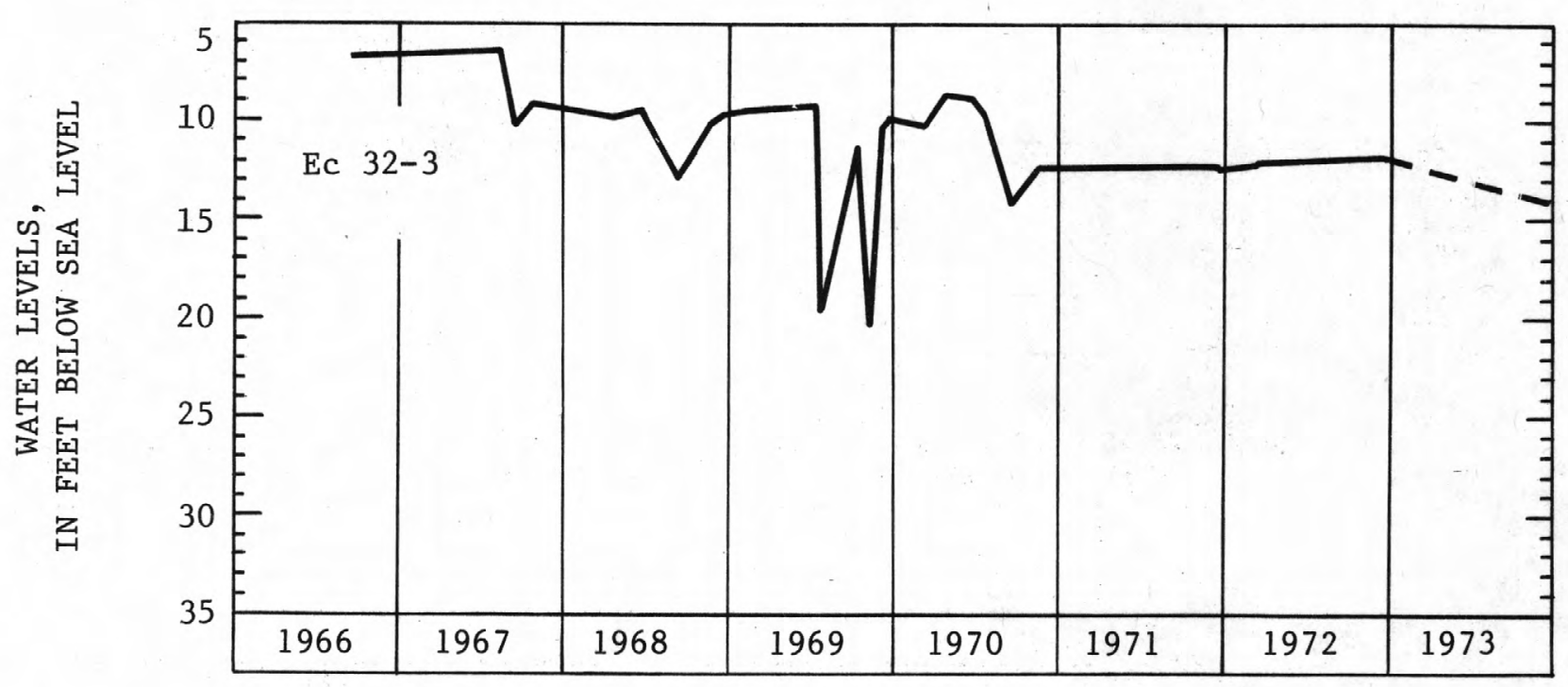

矛

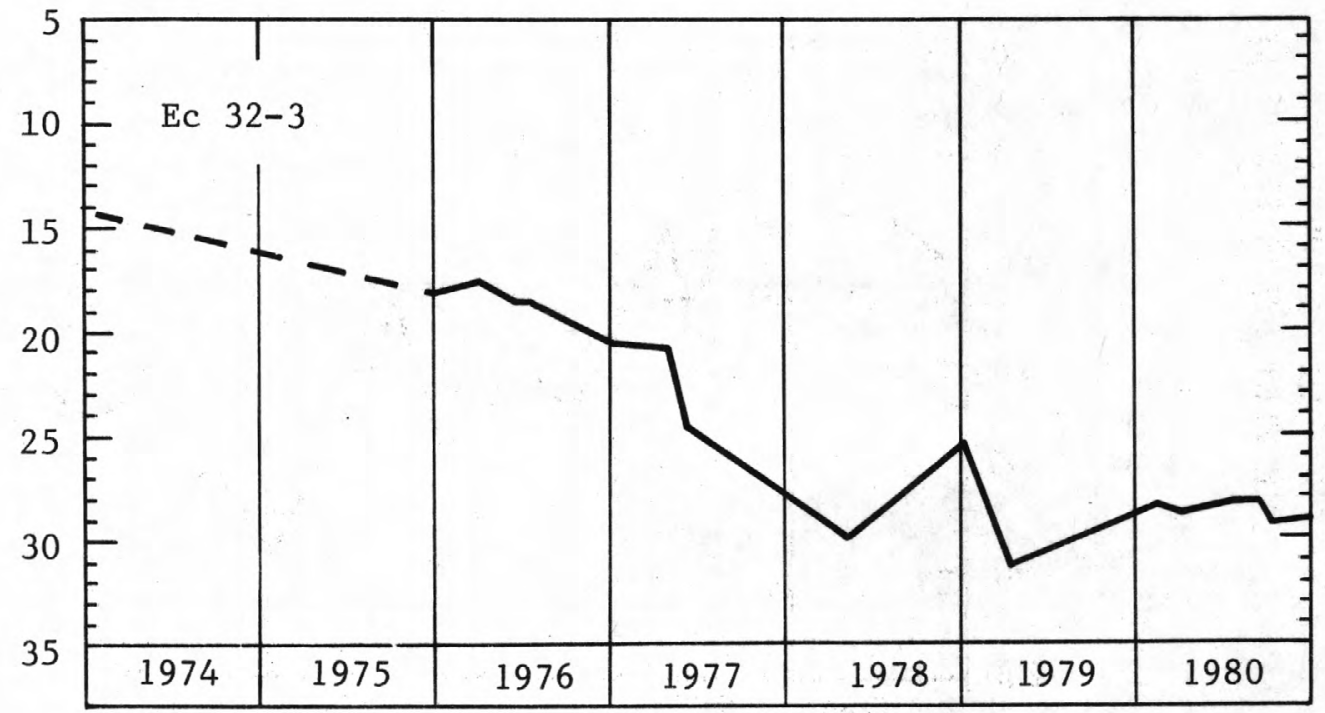

FIGURE 62.--Union Carbide. Water levels in Ec32-3, 1966-80. 
UNION CARBIDE

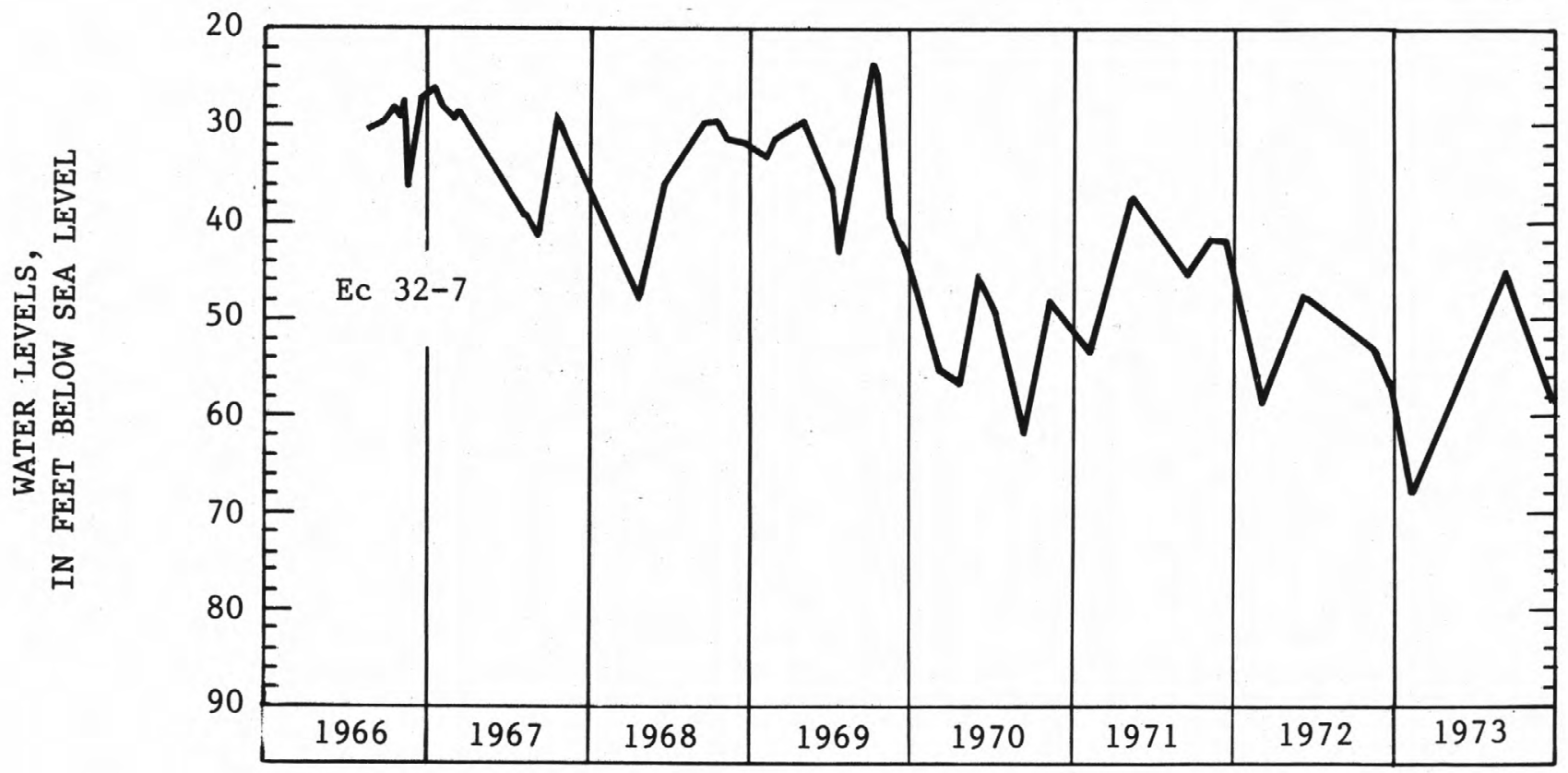

氠舅

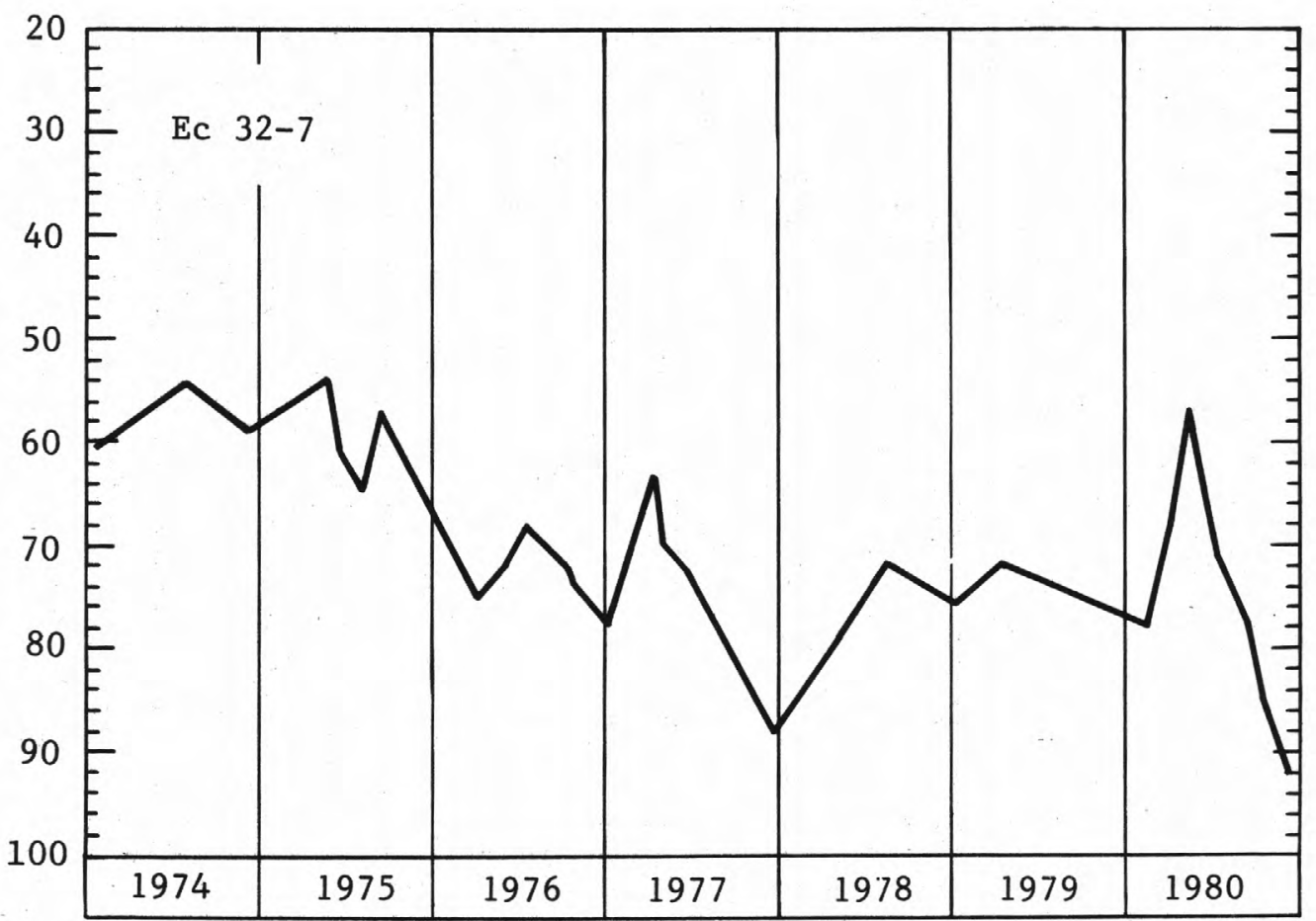

FIGURE 63.--Union Carbide. Water levels in Ec32-7, 1966-80. 
WILMINGTON AIRPORT

针
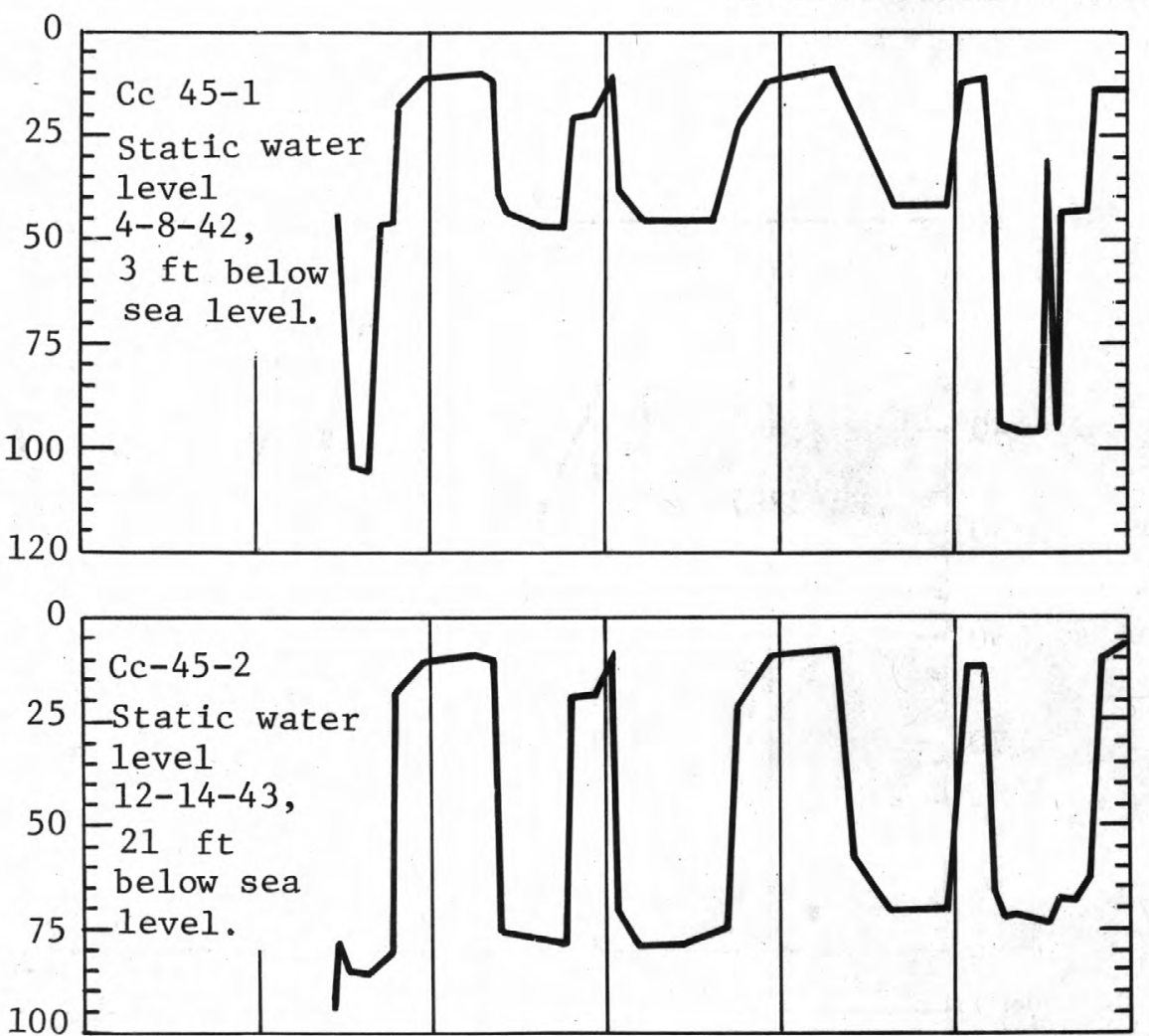

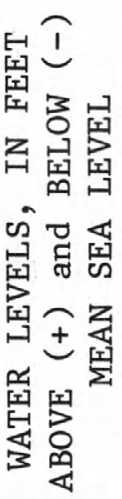

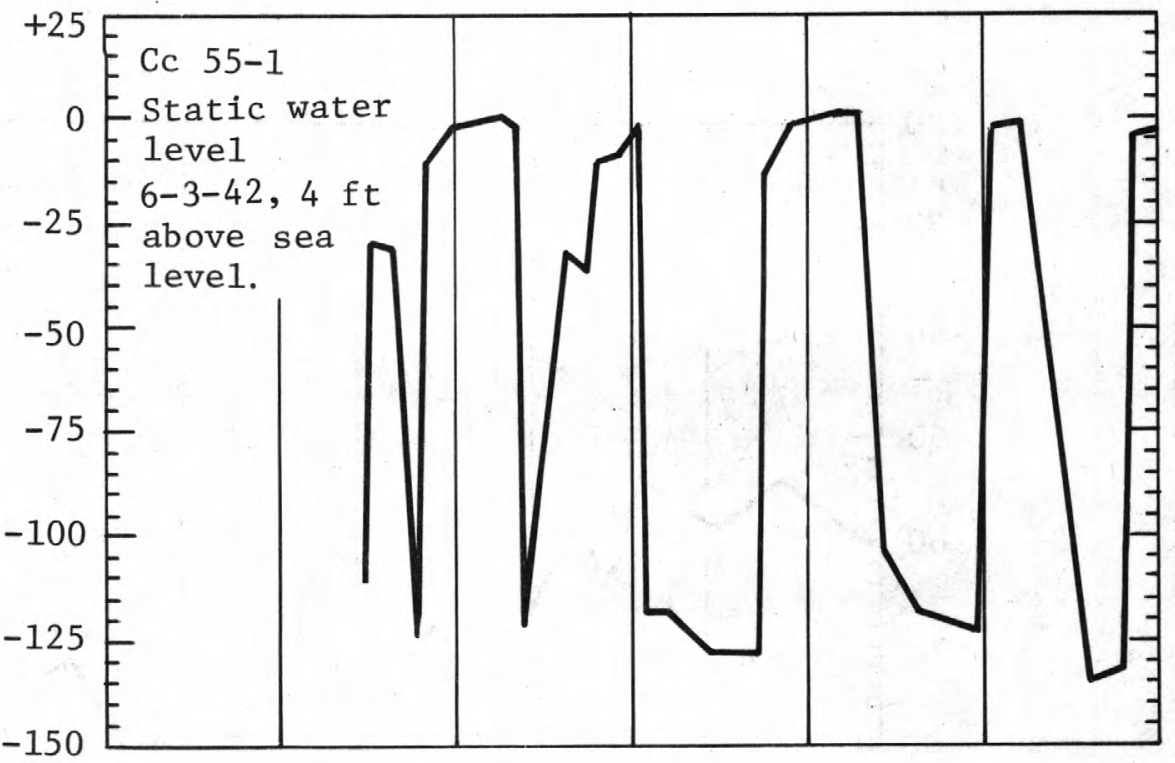

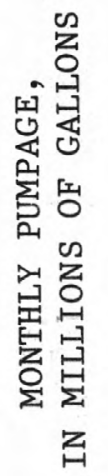

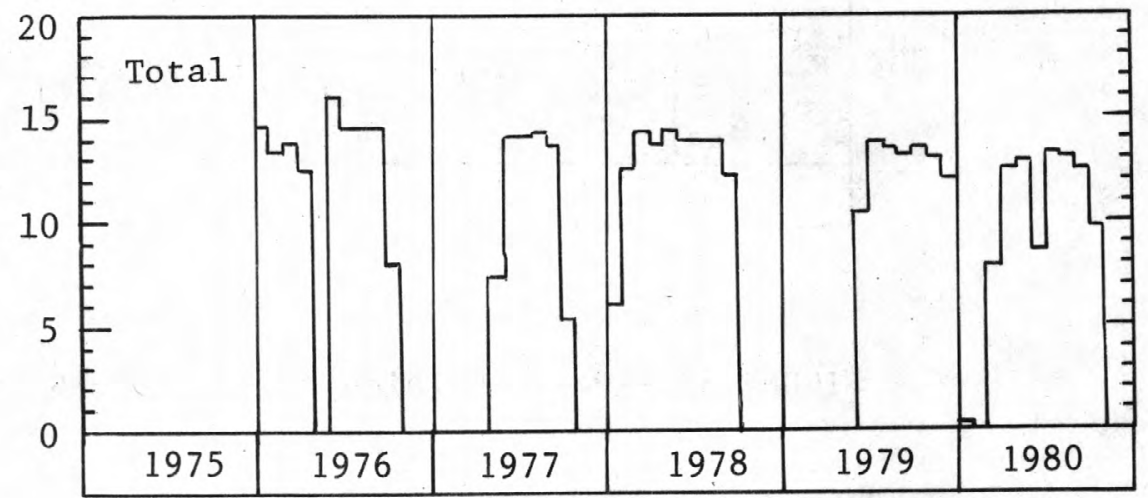

FIGURE 64.--Wilmington Airport. Total month1y pumpage from well field, 1976-80. Water levels in Cc45-1, Cc45-2, and Cc55-1, 1976-80. 

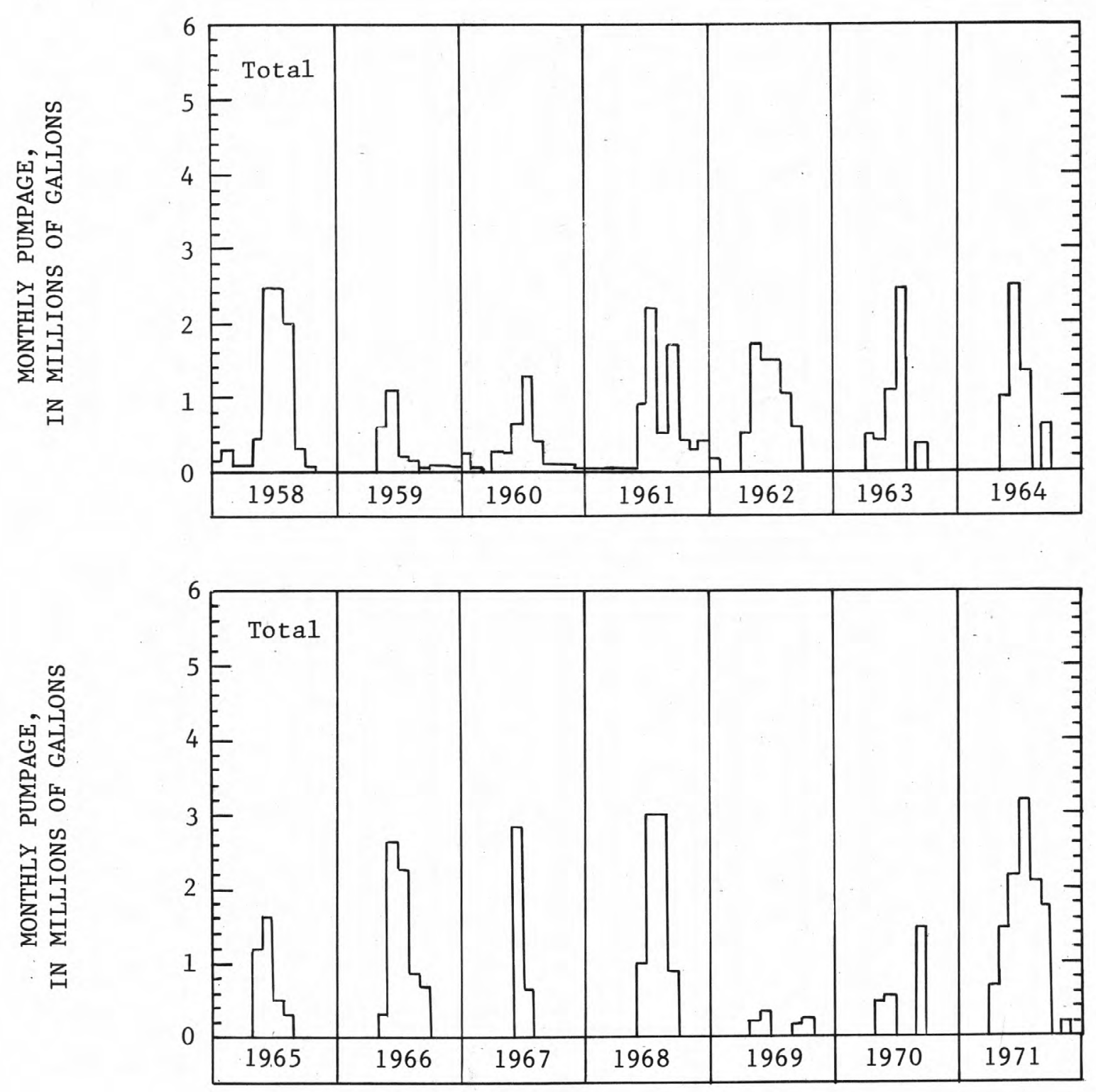

FIGURE 65.--Wilmington Manor. Total monthly pumpage from well field, 1958- 71. 
WILMINGTON MANOR GARDENS

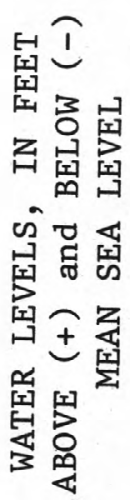
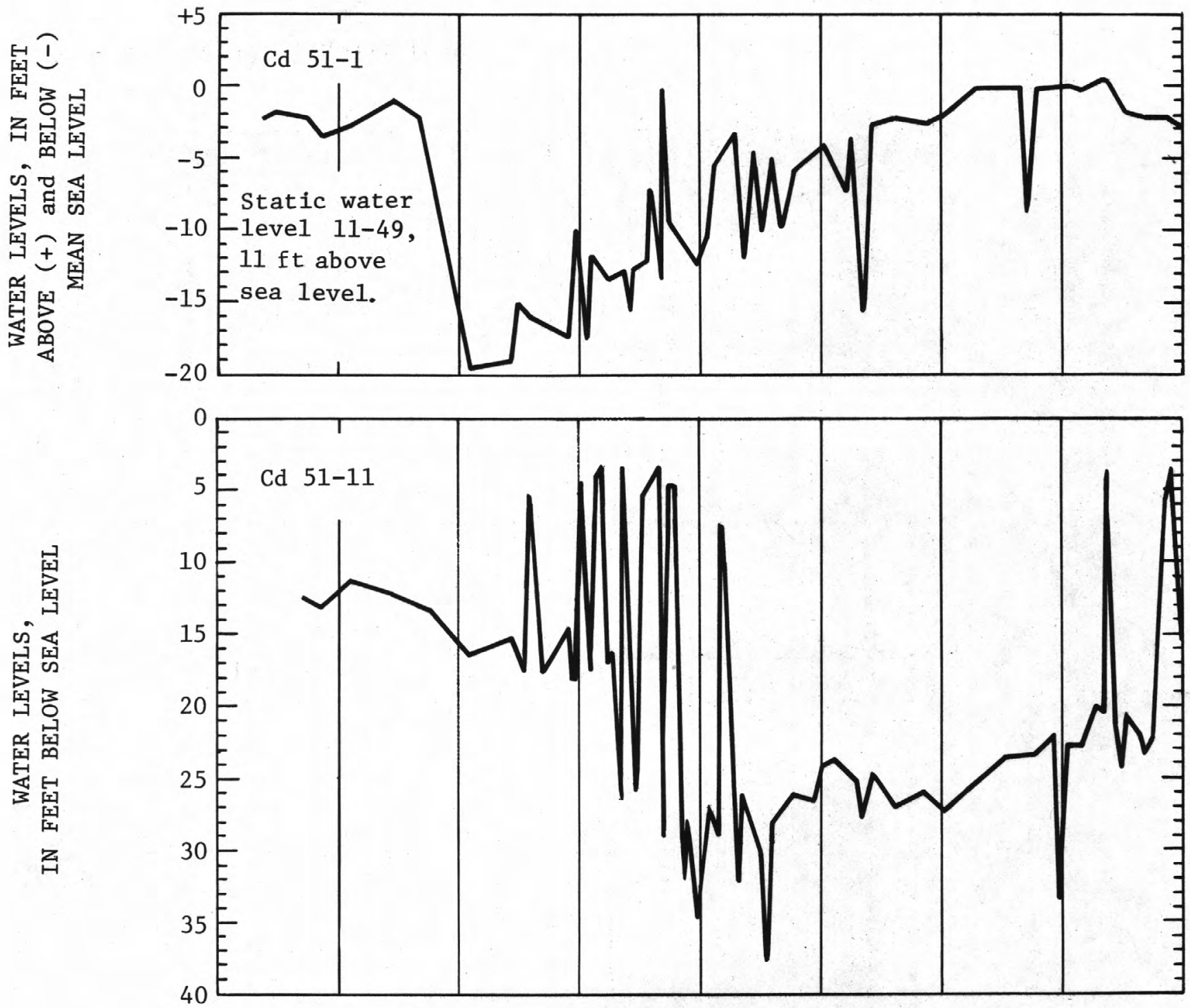

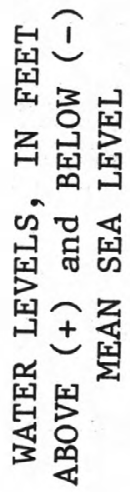

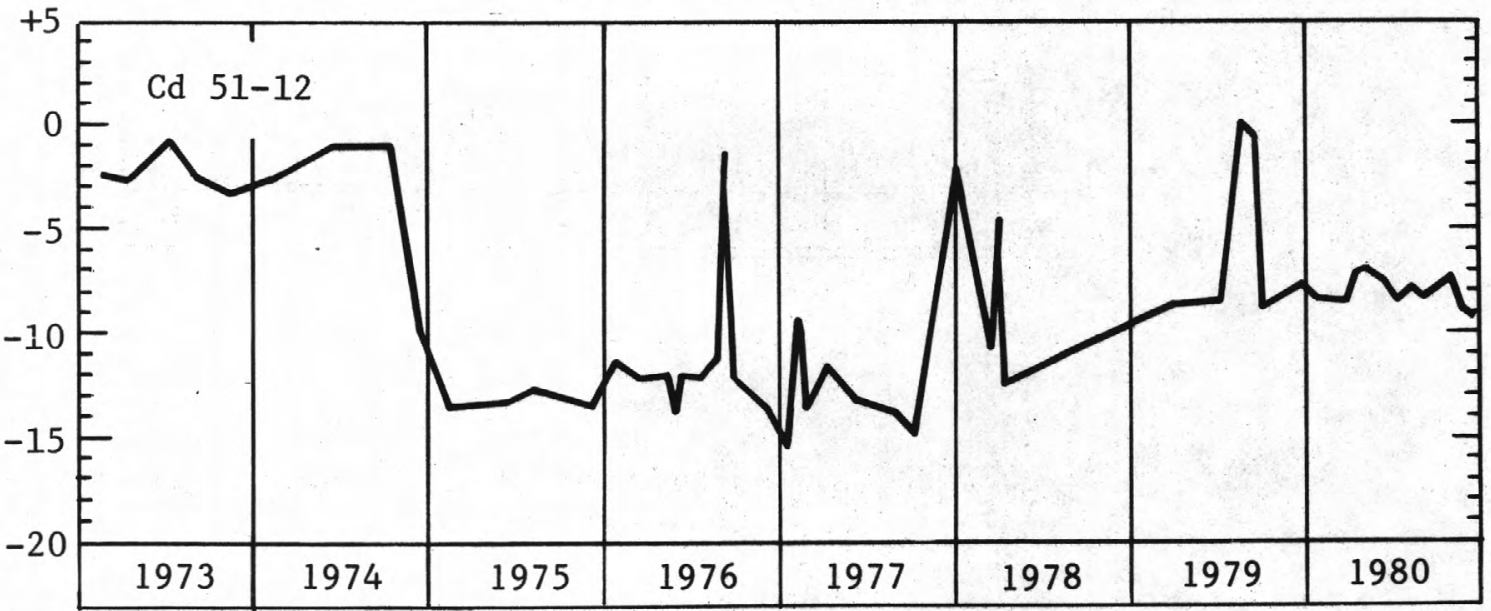

FIGURE 66.--Wilmington Manor Gardens. Water levels in Cd51-1, Cd51-11, and Cd51-12, 1973-80. 
WILMINGTON MANOR GARDENS
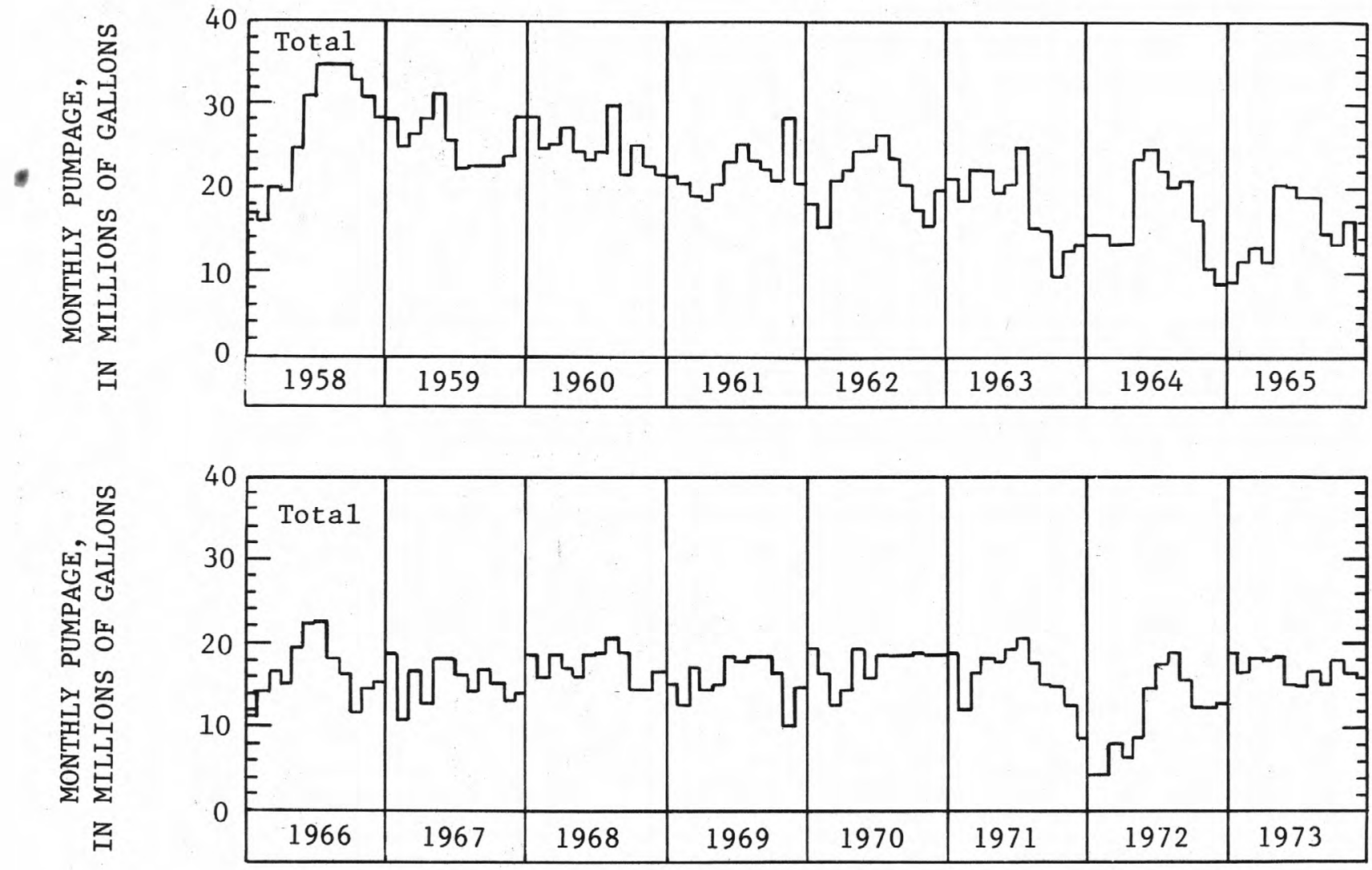

员

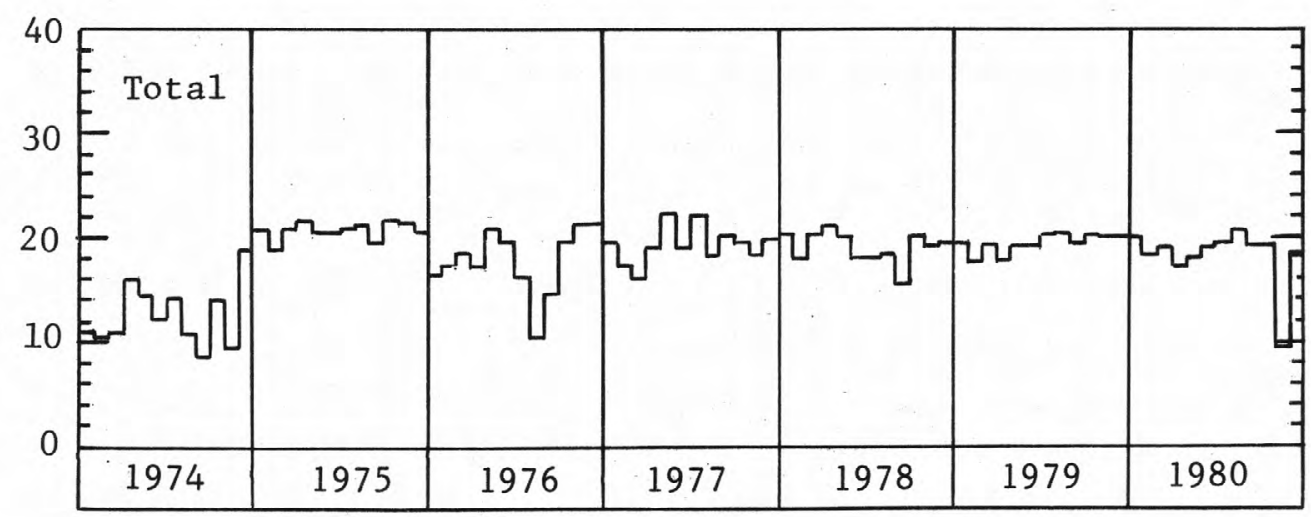

FIGURE 67.--Wilmington Manor Gardens. Total monthly pumpage from well field, 1958-80. 


\section{Ground-Water Levels}

Table 4 lists water levels in wells in the Potomac Formation. Hydrographs for wells with several years of water-level data have been included in figures 10 through 67. The data were compiled from previous publications; records from the Delaware Department of Natural Resources and Environmental Control, Delaware Geological Survey, and the U.S. Geological Survey; and from information supplied by the municipalities, industries, and public water supply companies.

Graphs of water levels appear with monthly pumpage graphs for that well field in figures 10 through 67. The name of the well field appears in the upper right corner of the page, and the well number appears in the upper left corner of the hydrograph. Where possible, graphs of water levels for a particular well have been placed directly above graphs of pumpage from that well or a nearby well with a similar screened interval. Locations of those wells with hydrographs are shown in figure 9.

All water levels listed in table 4 or shown in figures 10 through 67 are in feet above or below sea level. These levels are calculated by subtracting the depth to water from the measuring point altitude listed in table 7 . In wells with unknown measuring point altitudes, absolute water-level altitudes cannot be determined. In such wells, water-level altitudes are estimated from land-surface altitudes. Although these water-level data cannot be considered exact, the data provide approximate water levels and indicate relative changes in the potentiometric surface through time.

Water levels for production wells or for wells near production wells are affected by short-term changes in pumpage and can fluctuate greatly in short periods of time. Hydrographs for these wells may show extreme water-level changes that primarily reflect the production rate at the time of measurement and appear unrelated to monthly pumpage. In such wells, several years of monthly water-level measurements are needed to analyze changes in the potentiometric surface. However, these hydrographs aid in providing a range of local water levels during periods of pumping and nonpumping. Water levels measured before 1955 are indicative of the potentiometric surface before significant pumping.

Depth-to-water measurements made by U.S. Geological Survey personnel are noted as such in table 4 and are accurate to within several hundredths of a foot. Other water-level data, collected from various sources, may be in error from 0.1 to $10 \mathrm{ft}$, depending on the method of measurement and type of equipment used. The accuracy of measurements before 1950 is particularly hard to verify. Although an attempt was made to eliminate errors and inconsistencies in all water levels reported here, the lack of standardized measuring methods limits the use of these data. However, these data can provide useful water-level altitudes and indicate changes in the potentiometric surface if these limitations are considered. 
TABLE 4.--Water Levels in the Potomac Formation in New Castle County, Del.

Water Level: feet above $(+)$ or below $(-)$ sea level. H, hydrograph of water levels appears in preceding section. Figures are rounded to same significant digit as in depth to water.

Depth to Water: distance in feet from measuring point to water surface. Distance is assumed to be measured from land surface to water surface if measuring point is unknown.

\begin{tabular}{|c|c|c|c|c|c|c|c|}
\hline We11 & Date & $\begin{array}{l}\text { Water } \\
\text { Level }\end{array}$ & $\begin{array}{l}\text { Depth to } \\
\text { Water }\end{array}$ & Well & Date & $\begin{array}{l}\text { Water } \\
\text { Level }\end{array}$ & $\begin{array}{l}\text { Depth to } \\
\text { Water }\end{array}$ \\
\hline \multicolumn{2}{|c|}{$\begin{array}{l}\text { Airport Industrial } \\
\text { - Park }\end{array}$} & & & Amoco & & & \\
\hline De14-14 & $\begin{array}{l}4--78 \\
11-15-78 \\
12-15-78 \\
1-15-79 \\
2-15-79 \\
3-15-79 \\
4-15-79 \\
5-20-79 \\
6-15-79 \\
7-15-79 \\
8-17-79 \\
9-15-79 \\
10-15-79 \\
11-15-79 \\
12-15-79 \\
1-15-80 \\
2-15-80 \\
3-15-80 \\
4-15-80 \\
6-15-80 \\
7-15-80 \\
8-15-80 \\
9-15-80 \\
10-15-80 \\
11-15-80 \\
12-15-80\end{array}$ & 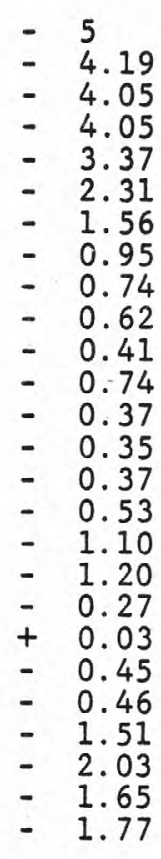 & $\begin{array}{l}22 \\
20.99 \\
20.85 \\
20.85 \\
20.17 \\
19.11 \\
18.36 \\
17.75 \\
17.54 \\
17.42 \\
17.21 \\
17.54 \\
17.17 \\
17.15 \\
17.17 \\
17.33 \\
17.90 \\
18.00 \\
17.07 \\
16.77 \\
17.25 \\
17.26 \\
18.31 \\
18.83 \\
18.45 \\
18.57\end{array}$ & $\begin{array}{l}\text { Dc15-17 } \\
\text { Dc15-18 } \\
\text { Dc15-19 } \\
\text { Dc15-20 } \\
\text { Dc24-6 } \\
\text { Dc25-16 }\end{array}$ & $\begin{array}{l}\text { 3- }-70 \\
1-29-74 \\
\\
4--61 \\
4--65 \\
6-3-66 \\
3-13-68 \\
3-18-68 \\
3-21-68 \\
11-25-69 \\
1-16-74 \\
1-24-74 \\
1-24-74\end{array}$ & $\begin{aligned}- & 46.9 \\
- & 297 \\
-111 & \\
-286.9 & = \\
-320 & \\
& H \\
& H \\
- & 25 \\
- & 16.7 \\
& H \\
& H \\
+ & 1.2 \\
- & 22 \\
- & 16 \\
- & 15 \\
- & 14.5 \\
- & 14.19 \\
- & 17.11 \\
- & 19.54 \\
- & 19.42 \\
- & 178.04\end{aligned}$ & $\begin{array}{l}69.9 \\
320 \\
134 \\
309.9 \\
343 \\
\\
\\
43 \\
34.8\end{array}$ \\
\hline Dc15-13 & $\begin{array}{l}3--75 \\
10-15-76 \\
4-15-77 \\
10-21-77 \\
4-18-78 \\
10-17-78\end{array}$ & $\begin{array}{l}+\quad 3.1 \\
+\quad 2.70 \\
+\quad 1.39 \\
-\quad 1.01 \\
+\quad 4.18 \\
+\quad 0.30\end{array}$ & $\begin{array}{l}19.4 \\
19.79 \\
21.10 \\
23.50 \\
26.67 \\
22.19\end{array}$ & Dc25-17 & $\begin{array}{l}4-17-61 \\
2-28-68 \\
3-11-68 \\
3-11-69 \\
9--72 \\
1-24-74\end{array}$ & $\begin{array}{l}-0.3 \\
-20 \\
-27 \\
-23 \\
-48 \\
-55\end{array}$ & $\begin{array}{l}25.8 \\
45 \\
52 \\
48 \\
73 \\
80\end{array}$ \\
\hline Dc15-14 & $\begin{array}{l}-1-17-75 \\
10-15-76 \\
4-15-77\end{array}$ & $\begin{array}{l}+2 \\
-\quad 1.08 \\
-\quad 2.53\end{array}$ & $\begin{array}{l}20 \\
22.88 \\
24.33\end{array}$ & $\frac{\text { Army Creek }}{\text { Dc14-13 }}$ & & $\mathrm{H}$ & \\
\hline Amoco & & & & Dc14-19 & & $\mathrm{H}$ & \\
\hline Dc14-13 & $\begin{array}{l}11--66 \\
3-1-74\end{array}$ & $\begin{array}{l}-4 \\
-\quad 8.41\end{array}$ & $\begin{array}{l}20 \\
24.16\end{array}$ & Dc14-37 & & $\mathrm{H}$ & \\
\hline Dc15-9 & $\begin{array}{l}5-9-61 \\
5-31-61 \\
1-24-66 \\
3-11-69 \\
1-24-74 \\
10-15-76 \\
4-15-77\end{array}$ & $\begin{array}{l}+2.15 \\
+\quad 2.59 \\
-21 \\
-81 \\
-72 \\
-76.01 \\
-73.01\end{array}$ & $\begin{array}{l}19.95 \\
19.51 \\
43 \\
103 \\
94 \\
98.11 \\
95.11\end{array}$ & $\begin{array}{l}\text { De14-41 } \\
\text { Dc14-46 } \\
\text { Dc15-15 }\end{array}$ & & $\begin{array}{l}\mathrm{H} \\
\mathrm{H}\end{array}$ & \\
\hline
\end{tabular}

1 Continuous record collected by U.S. Geological Survey since 10-30-78. 
TABLE 4.--Water levels in the Potomac Formation in New Castle County--Continued

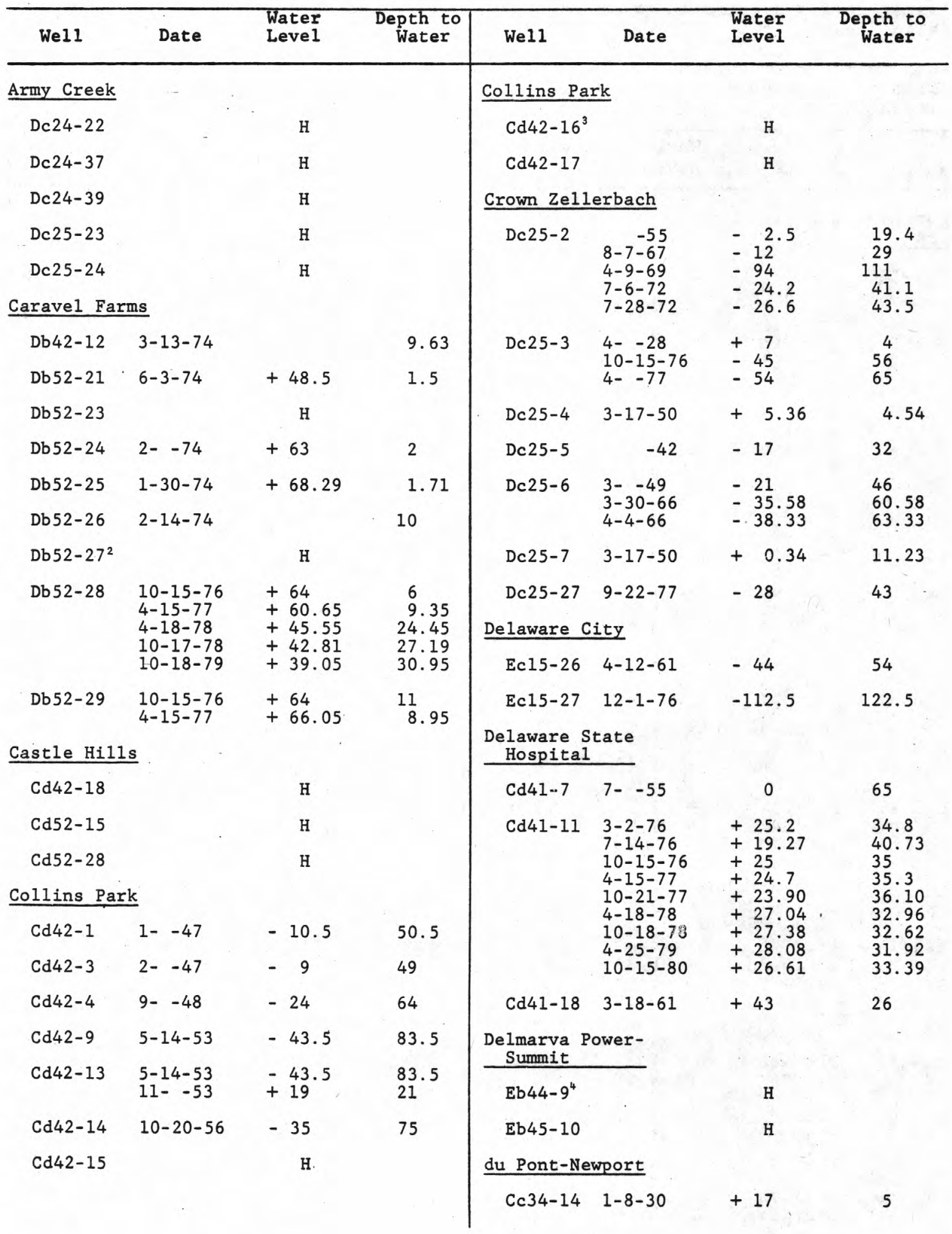

2 Continuous record collected by U.S. Geological Survey since 5-29-79.

3 Continuous record collected by U.S. Geological Survey since 6-6-79.

3 Continuous record collected by U.S. Geological Survey since 5-11-79. 
TABLE 4.--Water levels in the Potomac Formation in New Castle County--Continued

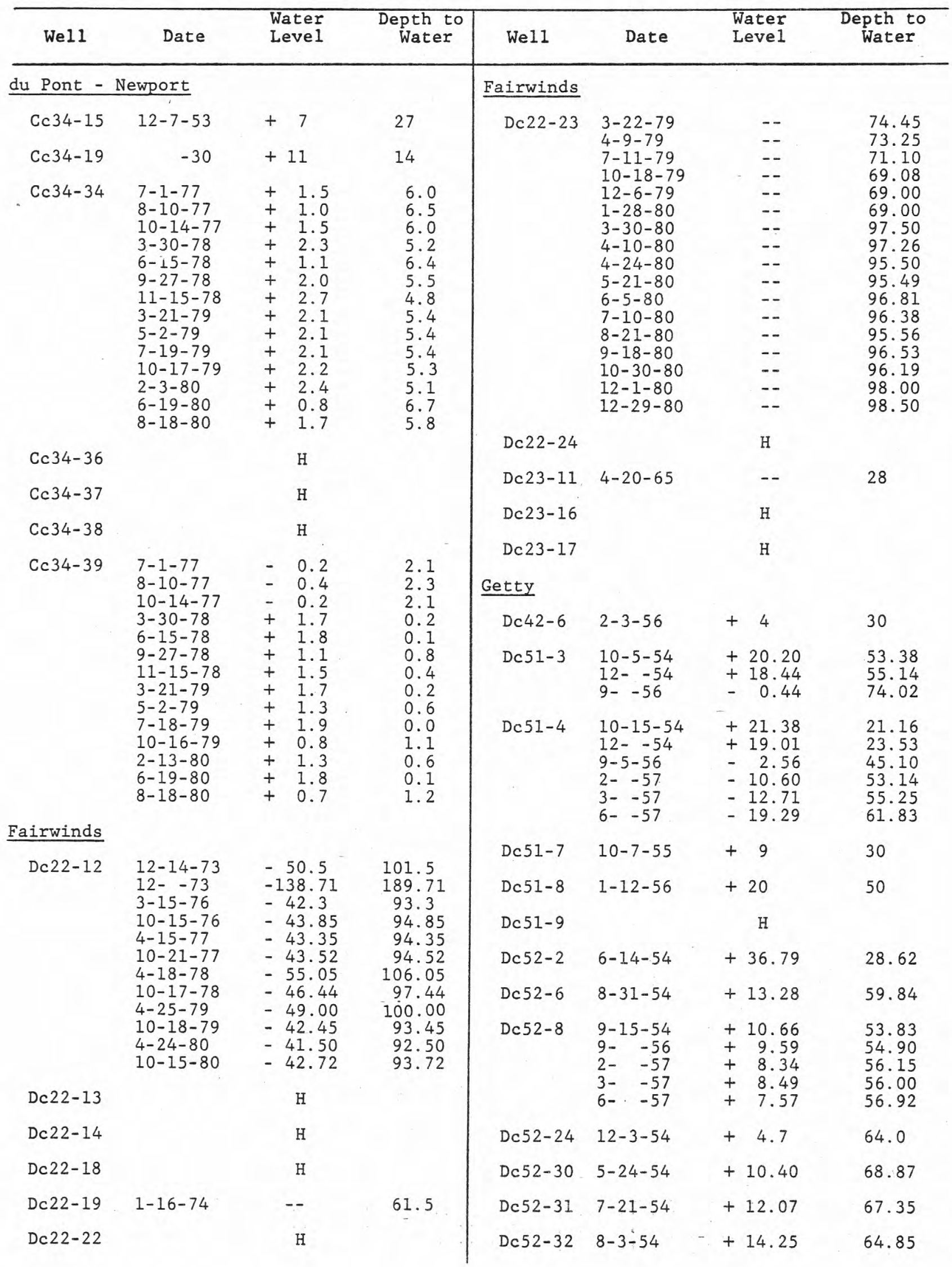


TABLE 4.--Water levels in the Potomac Formation in New Castle County--Continued

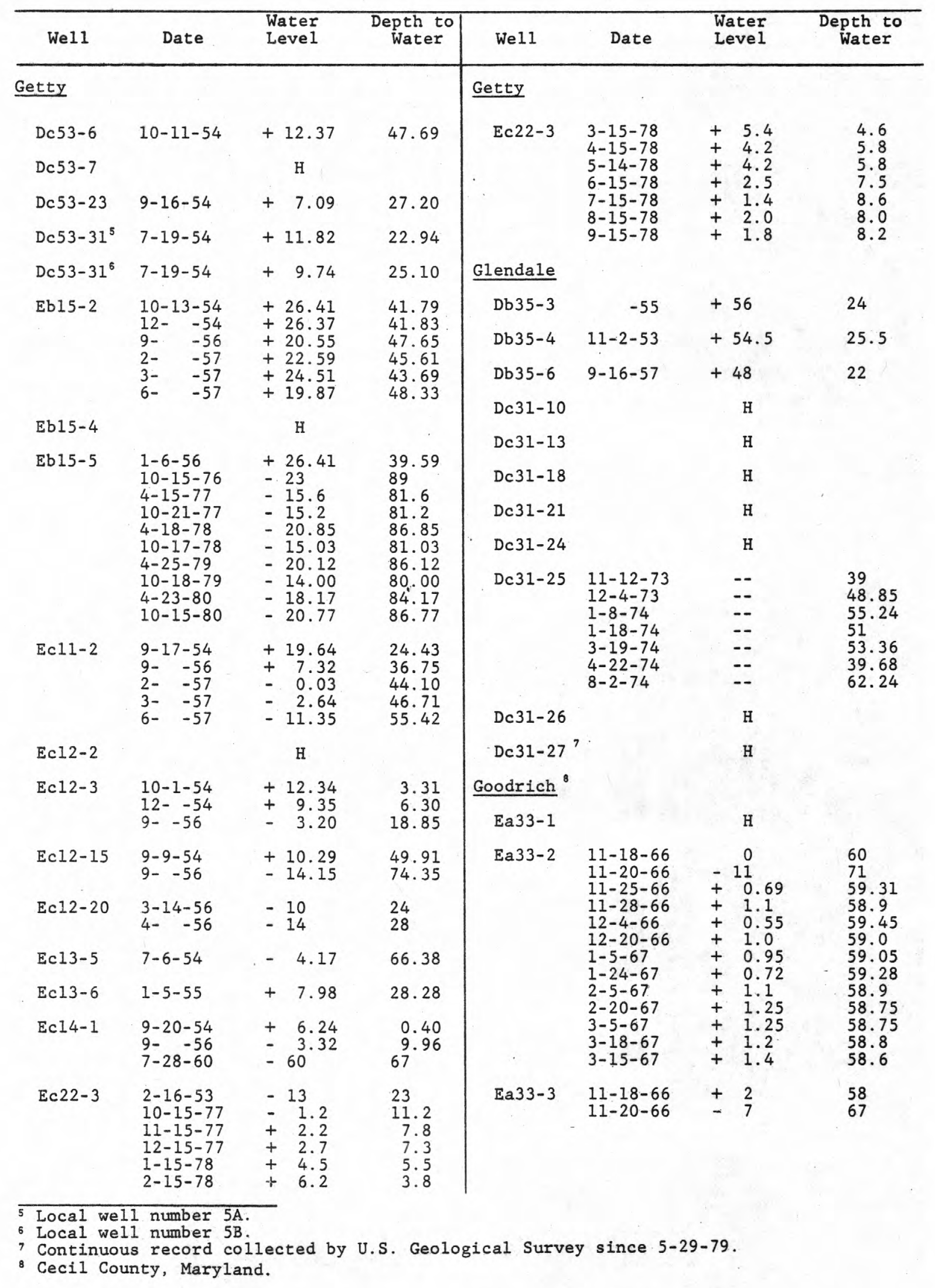


TABLE 4.--Water levels in the Potomac Formation in New Castle County--Continued

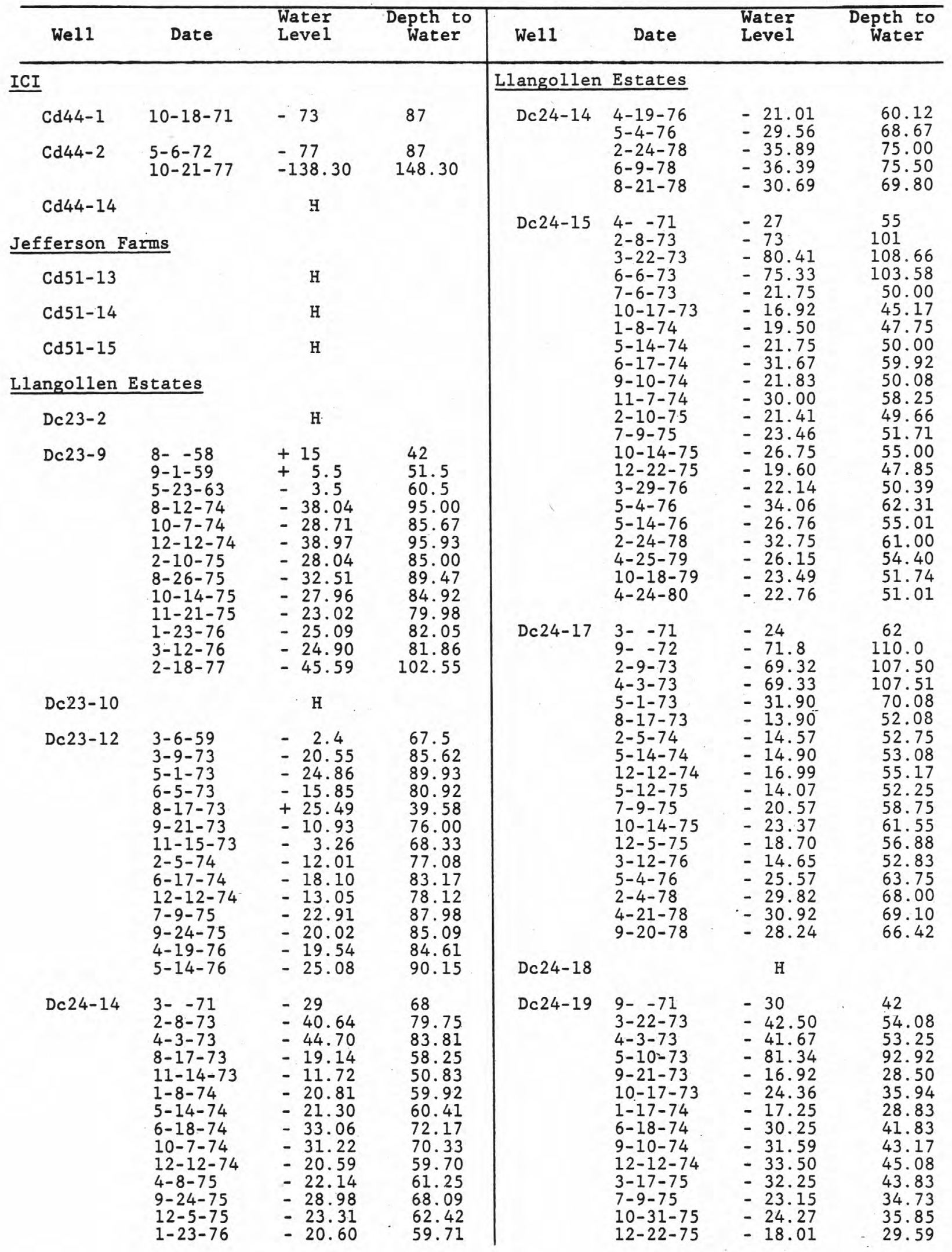


TABLE 4.--Water levels in the Potomac Formation in New Castle County--Continued

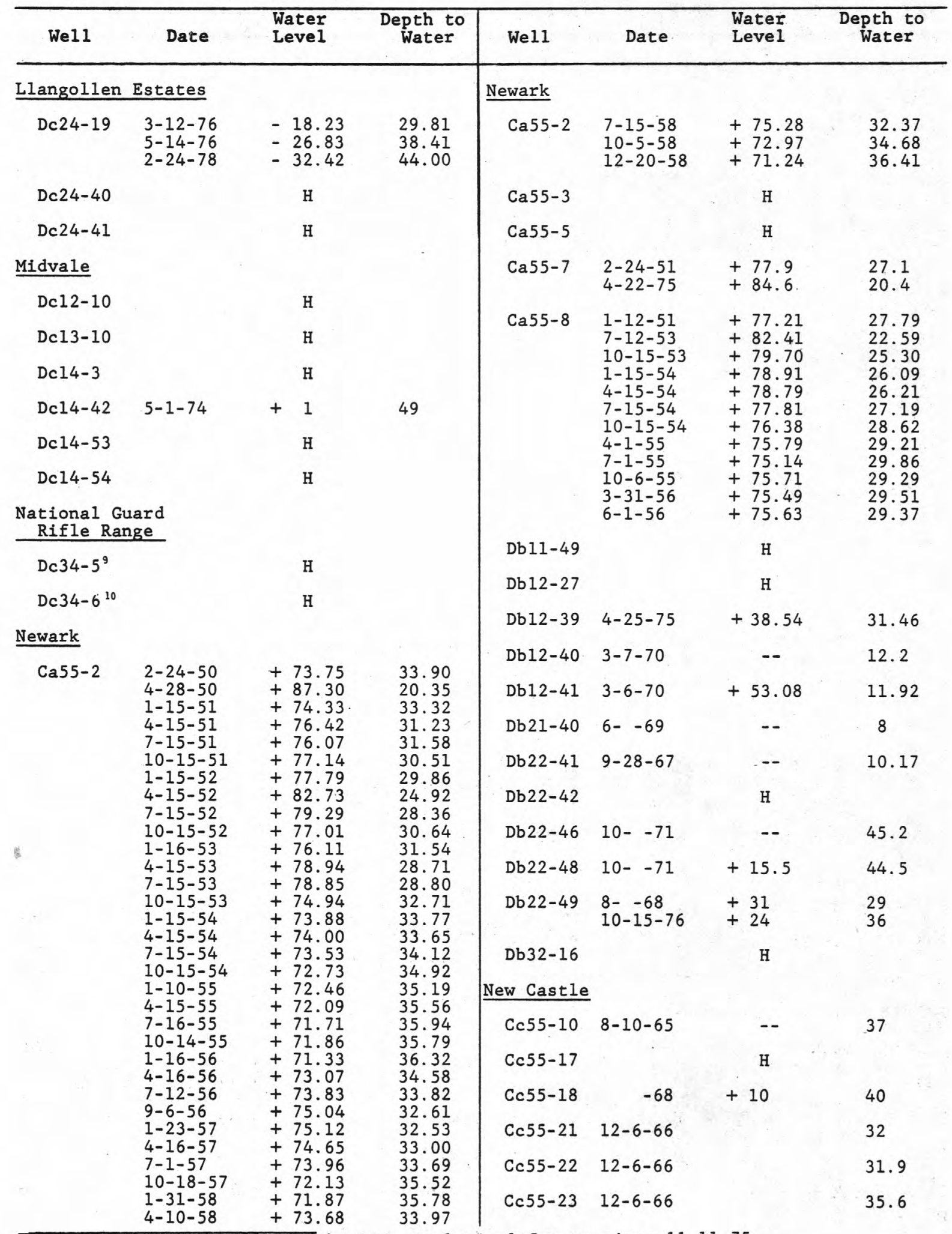

9 Monthly record collected by U.S. Geological Survey since 11-11-75..

10 Continuous record collected by U.S. Geological Survey since 11-11-75: 
TABLE 4.--Water levels in the Potomac Formation in New Castle County--Continued

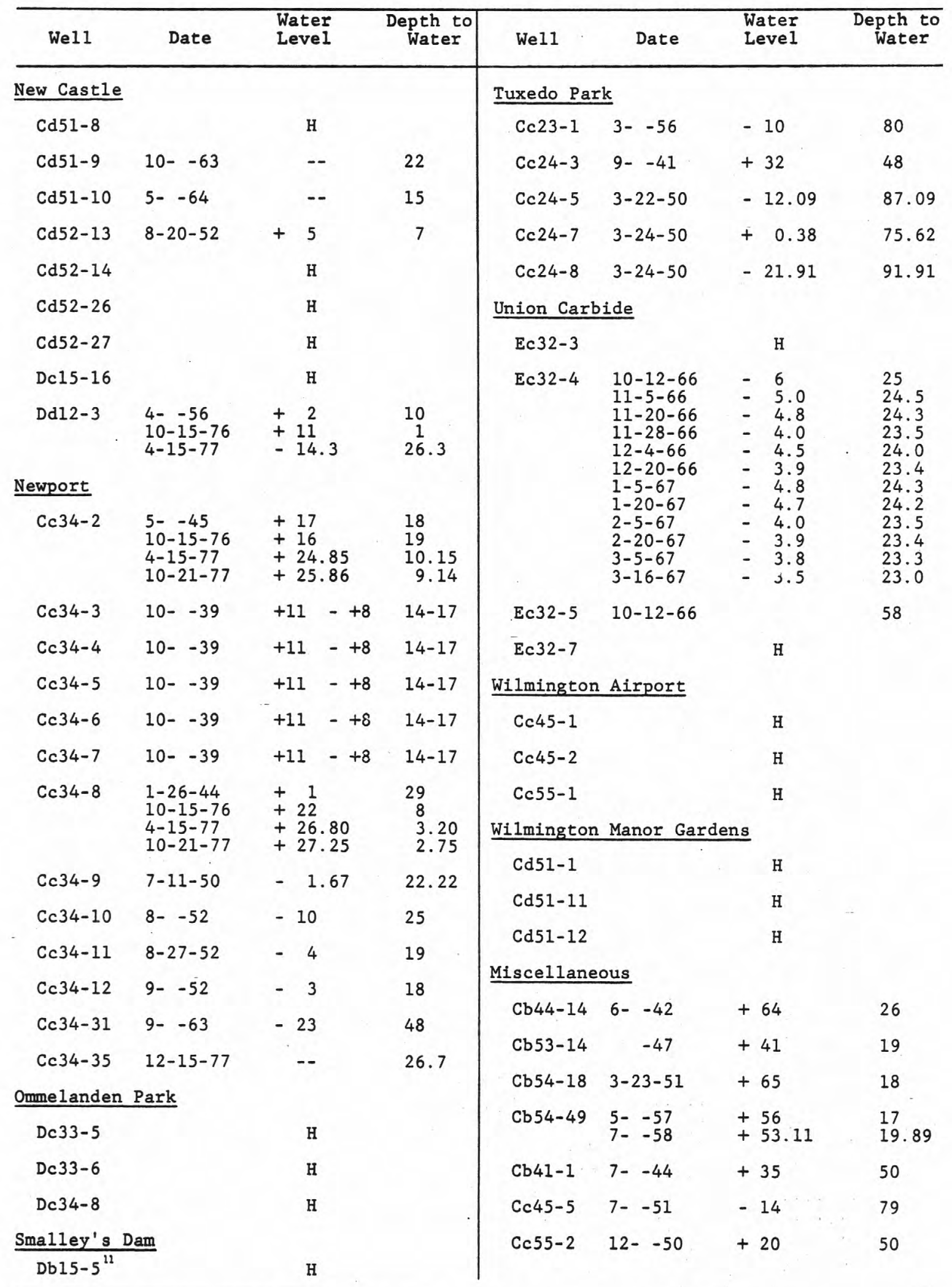

Continuous record collected by U.S. Geological Survey since 3-8-79. 
TABLE 4.--Water levels in the Potomac Formation in New Castle County--Continued

\begin{tabular}{|c|c|c|c|c|c|c|c|}
\hline Well & Date & $\begin{array}{l}\text { Water } \\
\text { Level }\end{array}$ & $\begin{array}{c}\text { Depth to } \\
\text { Water }\end{array}$ & Well & Date & $\begin{array}{l}\text { Water } \\
\text { Level }\end{array}$ & $\begin{array}{c}\text { Depth to } \\
\text { Water }\end{array}$ \\
\hline \multicolumn{4}{|c|}{ Miscellaneous } & \multicolumn{4}{|c|}{ Miscellaneous } \\
\hline $\operatorname{cd} 31-2$ & $12--48$ & +47 & 35 & Ec21-4 & $3--50$ & -6 & 61 \\
\hline $\operatorname{cd} 32-5$ & $5--42$ & +30 & 44 & Ec44-1 & $3--50$ & +6 & 19 \\
\hline $\operatorname{cd} 32-6$ & $12--44$ & +5 & 70 & Ed51-1 & $1-20-46$ & +6 & 5 \\
\hline Cd33-1 & $12--50$ & -0.5 & 10.5 & & & & \\
\hline Cd42-6 & $5--42$ & +14 & 61 & & & & \\
\hline $\operatorname{cd} 42-7$ & $5--42$ & +30 & 45 & & & & \\
\hline $\mathrm{Db} 14-14$ & $4-6-42$ & +18 & 52 & & & & \\
\hline Db15-1 & -51 & +27 & 3 & & & & \\
\hline Db15-4 & $4-8-50$ & -1 & 51 & & & & \\
\hline Db33-8 & $5--54$ & +1 & 39 & & & & \\
\hline Db41-5 & $8--61$ & +39 & 35 & & & & \\
\hline Dcl1-3 & -42 & +43.5 & 63.5 & & & & \\
\hline Dcl2-3 & $9--53$ & +15 & 60 & & & & \\
\hline Dc12-4 & $7--53$ & +30 & 30 & & & & \\
\hline Dc13-1 & $2--42$ & +1 & 65 & & & & \\
\hline Dc13-2 & $9--42$ & +33.5 & 21.5 & & & & \\
\hline Dc14-1 & $7--44$ & -15 & 50 & & & & \\
\hline Dc22-1 & $9-11-46$ & +36 & 26 & & & & \\
\hline Dc22-2 & $9-18-46$ & +40 & 23 & & & & \\
\hline Dc22-3 & $9-18-46$ & +37.5 & 26.5 & & & & \\
\hline Dc22-8 & $5-16-55$ & +56 & 19 & & & & \\
\hline Dc23-1 & $3--49$ & +11.3 & 5.7 & & & & \\
\hline Dc25-8 & $7--44$ & -25 & 50 & & & & \\
\hline Dc25-9 & $4-15-50$ & -4 & 36 & & & & \\
\hline Dc25-14 & $7--40$ & -5.5 & 30.5 & & & & \\
\hline Dc32-2 & $2-4-54$ & -35 & 95 & & & & \\
\hline Dc32-3 & $10-5-53$ & -48 & 118 & & & & \\
\hline Eb $24-1$ & $10-19-43$ & +19.92 & 51.08 & & & & \\
\hline Eb 24-2 & $8--52$ & +21 & 24 & & & & \\
\hline Eb34-3 & $4-20-67$ & +1.92 & 56.28 & & & & \\
\hline
\end{tabular}


Table 5 shows chemical analyses for wells in the Potomac Formation. Waterquality data were compiled from previous publications and from records at the Delaware Department of Natural Resources and Environmental Control and the Delaware Geological Survey. The data included in table 5 are generally historical. Many of the analyses reported in table 5 are the earliest water-quality data available for the wells listed.

The Delaware Department of Natural Resources and Environmental Control regularly receives or collects water-quality analyses of samples from monitor wells near several waste disposal sites including: Army Creek landfill, du Pont-Newport, Cherry Island (1.5 mi southeast of Wilmington), and Pigeon Point (directly north of the ICI well field). At these sites, additional water-quality data are available for monitor wells in the Potomac Formation or the Pleistocene sediments above the Potomac subcrop. However, because of the large volume of repetitive data, analyses from these sites are not included in this report.

\section{Surface-Water Discharge}

The locations of selected low-flow, continuous water-stage, and miscellaneous measuring stations are shown in figure 68. Data at these stations were collected by the U.S. Geological Survey. Low-flow discharge measurements and descriptions of the stations are given in table 6.

Hydrographs of daily discharge computed from water-stage records for the 1979 and 1980 water years are shown in figures 69 through 80. Additional longterm discharge records for Blackbird Creek at Blackbird have been published yearly by the U.S. Geological Survey since 1957.

Some basins with surface-water discharge stations are partly or entirely in the Potomac subcrop area. Other basins are in the subcrop area of overlying formations. Low-flow measurements were made after extended periods of no rainfall when streamflow is primarily from ground-water storage.

\section{APPLICATION OF FINDINGS}

Hydrologic data on the Potomac Formation in New Castle County were compiled. Enough data are available to document changes in the potentiometric surface of the Potomac aquifers, to make a detailed analysis of ground-water runoff, and to determine the effects of pumpage on ground-water levels. For these types of analyses to be more meaningful, investigation of the local geohydrologic properties of the aquifers and confining beds, their thickness, and areal extent is necessary.

A three-dimensional finite-difference model of the flow system in the Potomac Formation is planned by the U.S. Geological Survey from these data. This model would be useful in evaluating and predicting effects of increased groundwater development on future ground-water levels. 
TABLE 5.--Chemical analyses of water from the Potomac Formation in New Castle County, Del

[Results in milligrams per liter except as indicated; <10, less than 10] Specific conductance in micromhos per centimeter at $25^{\circ} \mathrm{C}$.

Other: BOD, biochemical oxygen demand; COD, chemical oxygen demand;

$\mathrm{Cu}$, copper; $\mathrm{H}_{2} \mathrm{~S}$, hydrogen sulfide; $\mathrm{K}$, potassium; $\mathrm{PO}_{4}$, phosphate; $\mathrm{Zn}$, zinc.

\begin{tabular}{|c|c|c|c|c|c|c|c|c|c|c|c|}
\hline Well & $\begin{array}{l}\text { Date } \\
\text { sam- } \\
\text { pled }\end{array}$ & $\mathrm{PH}$ & $\begin{array}{l}\text { Spe- } \\
\text { cific } \\
\text { con- } \\
\text { duc- } \\
\text { tance }\end{array}$ & $\begin{array}{l}\text { Total } \\
\text { dis- } \\
\text { solved } \\
\text { solids }\end{array}$ & $\begin{array}{l}\text { Iron } \\
\text { (Fe) }\end{array}$ & $\begin{array}{l}\text { Man- } \\
\text { ga- } \\
\text { nese } \\
(\mathrm{Mn})\end{array}$ & $\begin{array}{l}\text { Sodi- } \\
\text { um } \\
\text { (Na) }\end{array}$ & $\begin{array}{l}\text { Chlo- } \\
\text { ride } \\
\text { (Cl) }\end{array}$ & $\begin{array}{l}\text { Flo- } \\
\text { ride } \\
\text { (F) }\end{array}$ & $\begin{array}{l}\text { Cal- } \\
\text { cium } \\
\text { (Ca) }\end{array}$ & $\begin{array}{l}\text { Mag- } \\
\text { ne- } \\
\text { sium } \\
(\mathrm{Mg})\end{array}$ \\
\hline
\end{tabular}

\section{Airport \\ Industrial \\ Park}

Dc15-13 10-25-77 $6.0 \quad 110$

Amoco

\begin{tabular}{|c|c|c|c|c|c|c|c|c|c|c|c|}
\hline Del4- 3 & $10-31-66$ & 5.6 & -- & -- & 0.22 & 0.0 & -- & 2 & -- & -- & -- \\
\hline Dc15-7 & $5-4-67$ & -- & -- & -- & -- & -- & -- & 9 & -- & -- & -- \\
\hline Dc15-9 & $\begin{array}{l}6-1-61 \\
4-12-66 \\
9-22-72 \\
3-7-74 \\
11-6-74\end{array}$ & $\begin{array}{l}5.9 \\
5.8 \\
-- \\
6.3 \\
6.0\end{array}$ & $\begin{array}{l}-- \\
110 \\
121 \\
--\end{array}$ & $\begin{array}{r}-- \\
-- \\
108 \\
91\end{array}$ & $\begin{array}{l}0.1 \\
0.02 \\
-- \\
4.66 \\
1.68\end{array}$ & $\begin{array}{l}0 .- \\
-- \\
0.47 \\
0.25\end{array}$ & $\begin{array}{c}-- \\
\overline{--} \\
10.7 \\
9.4\end{array}$ & $\begin{aligned} & 8 \\
& 5 \\
& 21.3 \\
& 23 \\
&< 15\end{aligned}$ & $\begin{array}{l}-- \\
-- \\
-- \\
--\end{array}$ & $\begin{array}{l}-- \\
-- \\
-- \\
4.5 \\
2.2\end{array}$ & $\begin{array}{l}-- \\
-- \\
-- \\
--\end{array}$ \\
\hline Dc15- 10 & $\begin{array}{l}10-25-60 \\
9-22-72 \\
3-7-74 \\
10-1-74\end{array}$ & $\begin{array}{r}7.8 \\
-- \\
8.0 \\
7.6\end{array}$ & $\begin{array}{r}-- \\
170 \\
186 \\
--\end{array}$ & $\begin{array}{r}-- \\
143 \\
100\end{array}$ & $\begin{array}{l}0.2 \\
-- \\
0.45 \\
0.34\end{array}$ & $\begin{array}{l}0 \\
-- \\
<.1 \\
<.1\end{array}$ & $\begin{array}{l}-- \\
20 \\
42.0\end{array}$ & $\begin{array}{c}8 \\
13.4 \\
<10 \\
18\end{array}$ & $\begin{array}{l}-- \\
-- \\
--\end{array}$ & $\begin{array}{l}-- \\
-- \\
2.0 \\
3.7\end{array}$ & $\begin{array}{l}-- \\
-- \\
--\end{array}$ \\
\hline Dc. $15-20$ & $10-2-74$ & 6.7 & -- & 64 & 0.15 & $<.1$ & 6.7 & 15 & -- & 4.1 & -- \\
\hline Dc24-6 & $\begin{array}{l}3-5-74 \\
10-1-74\end{array}$ & $\begin{array}{l}6.9 \\
7.2\end{array}$ & -- & $\begin{array}{l}201 \\
193\end{array}$ & $\begin{array}{l}6.74 \\
10.0\end{array}$ & $\begin{array}{l}0.11 \\
0.12\end{array}$ & -- & $\begin{array}{l}49 \\
68\end{array}$ & -- & 18.5 & -- \\
\hline Dc25-16 & $5-4-67$ & -- & -- & -- & -- & -- & -- & 9 & -- & -- & -- \\
\hline Dc 25-17 & $\begin{array}{l}4-18-61 \\
9-22-72 \\
3-7-74 \\
10-1-74\end{array}$ & $\begin{array}{l}6.0 \\
-- \\
6.0 \\
6.9\end{array}$ & $\begin{array}{r}-- \\
160 \\
156 \\
--\end{array}$ & $\begin{array}{r}0.1 \\
-\overline{113} \\
74\end{array}$ & $\begin{array}{c}-- \\
-- \\
0.28 \\
0.23\end{array}$ & $\begin{array}{l}-- \\
-- \\
<.1 \\
0.10\end{array}$ & $\begin{array}{l}-- \\
20 \\
20.8\end{array}$ & $\begin{array}{l}4{ }^{4} .0 \\
31 \\
23\end{array}$ & $\begin{array}{l}-- \\
-- \\
--\end{array}$ & $\begin{array}{l}-- \\
-- \\
3.5 \\
8.1\end{array}$ & $\overline{--}$ \\
\hline
\end{tabular}

Caravel

Farms

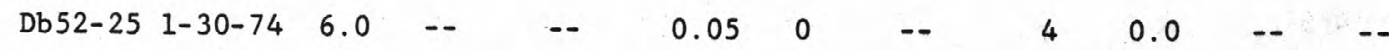

Collins

Park

\begin{tabular}{|c|c|c|c|c|c|c|c|c|c|c|}
\hline Cd42-1 & $1-18-54$ & -- & -- & -- & -- & -- & -- & 25 & -- & $\cdots$ \\
\hline Cd42-3 & $5-19-78$ & 7.2 & -- & -- & 0.84 & 0.03 & 21 & 1 & 0.0 & \\
\hline Cd42- 5 & $1-18-54$ & -- & -- & -- & -- & -- & -- & 7 & -- & \\
\hline Cd42-15 & $3-7-78$ & 5.8 & -- & -- & 0.07 & 0.02 & 15 & 35 & 0.0 & \\
\hline
\end{tabular}

Crown

Zellerbach

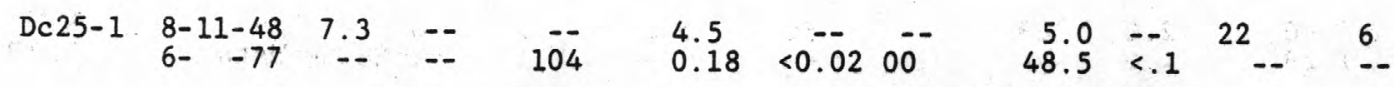


Source: BA, analysis by Brant Associates; BGB, analysis by Booth, Garrett, and Blair; DGS Delaware Geological Survey; DNREC, Delaware Department of Natural Resources and Environmental Control; G; Groot and Rasmussen, 1954; GM, Geraghty and Miller; LBG, Leggett, Brashears, and Graham; M, Marine and Rasmussen, 1955;

PB, analysis by Penniman and Browne; R, Rasmussen and Others, 1957; RW, koy F.

Weston; S, Sundstrom and Others, 1967; W, Woodruff, 1969.

\begin{tabular}{|c|c|c|c|c|c|c|c|c|c|c|}
\hline $\begin{array}{l}\text { Silica } \\
\left(\mathrm{SiO}_{2}\right)\end{array}$ & $\begin{array}{l}\text { Ni- } \\
\text { trate } \\
\text { Ni- } \\
\text { trogen } \\
(\mathrm{NO},-\mathrm{N})\end{array}$ & $\begin{array}{l}\text { Sul- } \\
\text { fate } \\
\left(\mathrm{SO}_{4}\right)\end{array}$ & $\begin{array}{l}\text { Total } \\
\text { hard- } \\
\text { ness } \\
\text { as } \\
\mathrm{CaCO} \text {. }\end{array}$ & $\begin{array}{l}\text { Non- } \\
\text { car- } \\
\text { bon- } \\
\text { ate } \\
\text { hard- } \\
\text { ness }\end{array}$ & $\begin{array}{l}\text { Bi- } \\
\text { car- } \\
\text { bon- } \\
\text { ate } \\
\left(\mathrm{HCO}_{3}\right)\end{array}$ & $\begin{array}{l}\text { Free } \\
\text { car- } \\
\text { bonic } \\
\text { acid } \\
\left(\mathrm{CO}_{2}\right)\end{array}$ & $\begin{array}{l}\text { Tur- } \\
\text { bid- } \\
\text { ity }\end{array}$ & $\begin{array}{l}\text { Alka- } \\
\text { lin- } \\
\text { ity }\end{array}$ & Other & Source \\
\hline
\end{tabular}

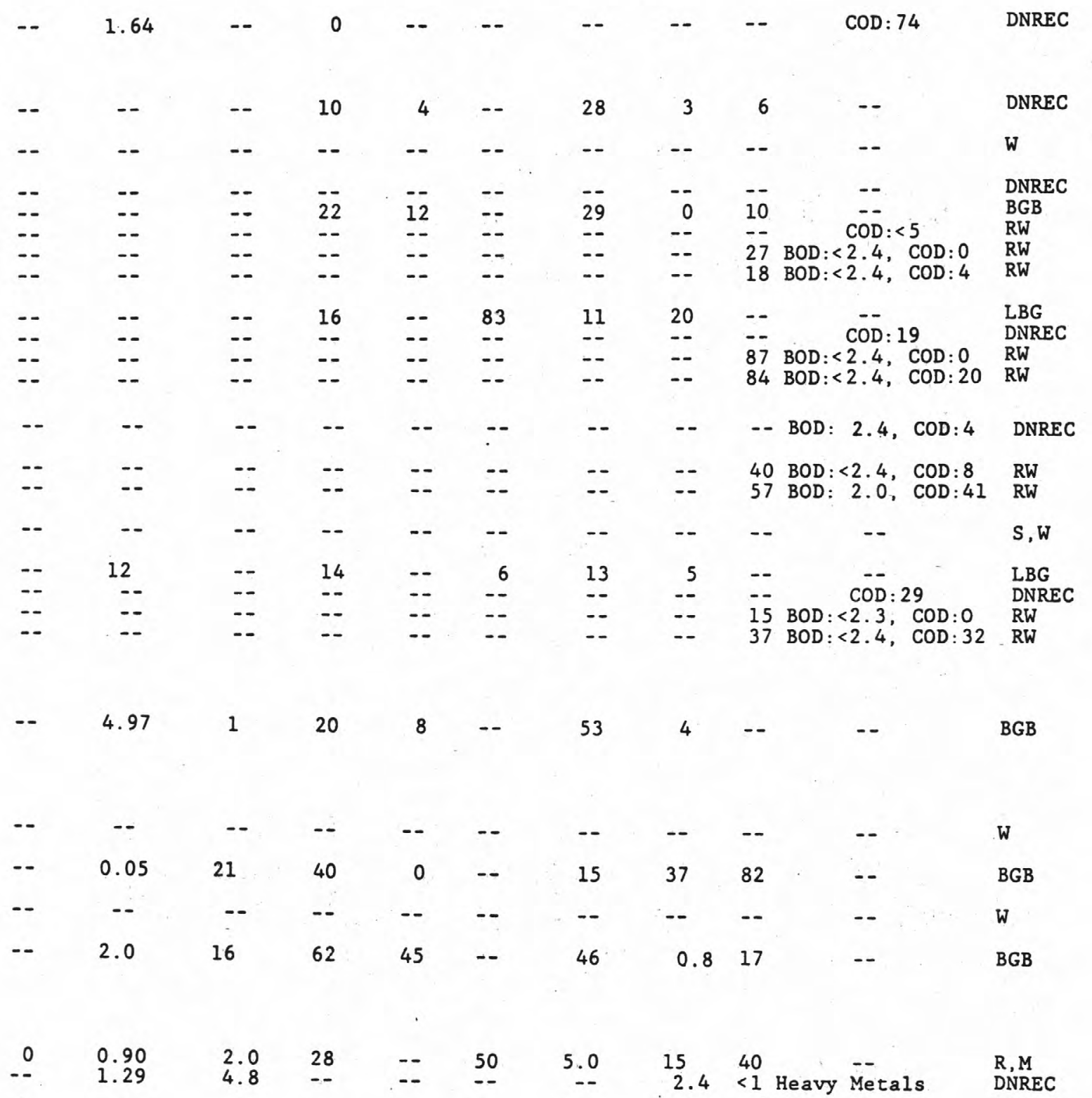


TABLE 5.--Chemical analyses of water from the Potomac Formation in New Castle County-Continued

\begin{tabular}{|c|c|c|c|c|c|c|c|c|c|c|c|}
\hline We11 & $\begin{array}{l}\text { Date } \\
\text { sam- } \\
\text { pled }\end{array}$ & $\mathrm{PH}$ & $\begin{array}{l}\text { Spe- } \\
\text { cific } \\
\text { con- } \\
\text { duc- } \\
\text { tance }\end{array}$ & $\begin{array}{l}\text { Total } \\
\text { dis- } \\
\text { solved } \\
\text { solids }\end{array}$ & $\begin{array}{l}\text { Iron } \\
(\mathrm{Fe})\end{array}$ & $\begin{array}{l}\text { Man- } \\
\text { ga- } \\
\text { nese } \\
(\mathrm{Mn})\end{array}$ & $\begin{array}{l}\text { Sodi- } \\
\text { um } \\
(\mathrm{Na})\end{array}$ & $\begin{array}{l}\text { Chlo- } \\
\text { ride } \\
\text { (C1) }\end{array}$ & $\begin{array}{l}\text { Flo- } \\
\text { ride } \\
\text { (F) }\end{array}$ & $\begin{array}{l}\text { Cal- } \\
\text { cium } \\
\text { (Ca) }\end{array}$ & $\begin{array}{l}\text { Mag- } \\
\text { ne- } \\
\text { sium } \\
\text { (Mg) }\end{array}$ \\
\hline
\end{tabular}

\section{Crown Zellerbach}

\begin{tabular}{|c|c|c|c|}
\hline Dc25-2 & $\begin{array}{l}2-16-37 \\
8-11-48 \\
8-20-51 \\
6-8-55 \\
6-29-55 \\
9-22-72\end{array}$ & $\begin{array}{l}-- \\
7.2 \\
-- \\
-- \\
6.0 \\
--\end{array}$ & $\begin{array}{c}-- \\
-- \\
-- \\
\overline{-} \\
56.8 \\
100\end{array}$ \\
\hline Dc25-3 & $\begin{array}{l}2-16-37 \\
8-11-48 \\
8-20-51 \\
9-22-72\end{array}$ & $\begin{array}{l}-- \\
6.6 \\
-- \\
--\end{array}$ & $\begin{array}{l}-- \\
-- \\
-- \\
33\end{array}$ \\
\hline Dc25-4 & $\begin{array}{l}8-11-48 \\
9-22-72\end{array}$ & 7.6 & $1 \overline{20}$ \\
\hline Dc25-5 & $\begin{array}{r}8-11-48 \\
1-\quad-66\end{array}$ & $\begin{array}{l}6.6 \\
5.6\end{array}$ & -- \\
\hline Dc25-6 & $\begin{array}{l}2-16-37 \\
8-11-48 \\
4-15-74\end{array}$ & $\begin{array}{l}6.2 \\
6.5 \\
5.7\end{array}$ & $\overline{--}$ \\
\hline Dc25- 10 & $8-15-51$ & -- & -- \\
\hline
\end{tabular}

Ec15-26 12-2-76 7.2 -- --

$0.620 .0 \quad 44 \quad 14 \quad 0.0$

Delmarva Power-Summit

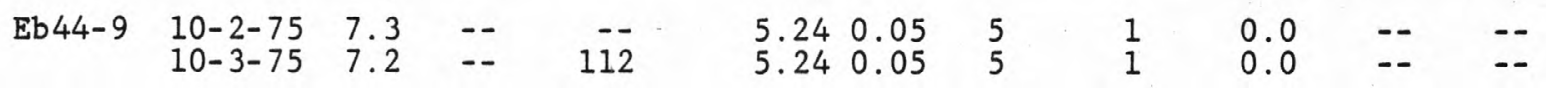

Fairwinds

$\begin{array}{lllllllllll}\operatorname{Dc} 22-18 & 4-1-74 & 5.8 & - & - & 0.50 & 0.02 & - & 13 & 0.0 & -\ldots\end{array}$

Getty

\begin{tabular}{|c|c|c|c|c|c|c|c|c|c|c|c|}
\hline Dc41-4 & $\begin{array}{l}10-12-55 \\
1-29-59 \\
5-4-67 \\
7-25-75 \\
7-16-76 \\
4-20-77\end{array}$ & $\begin{array}{l}6.5 \\
6.8 \\
-- \\
6.7 \\
6.8 \\
6.8\end{array}$ & $\begin{array}{l}-- \\
-- \\
-- \\
-- \\
-- \\
--\end{array}$ & $\begin{array}{r}154 \\
-- \\
\overline{96} \\
94 \\
138\end{array}$ & $\begin{array}{c}-- \\
4.7 \\
-- \\
6.0 \\
5.3 \\
11.3\end{array}$ & $\begin{array}{l}0.1 \\
-- \\
-- \\
0.06 \\
0.07 \\
0.07\end{array}$ & $\begin{array}{l}-- \\
-- \\
-- \\
-- \\
-- \\
--\end{array}$ & $\begin{array}{l}4.5 \\
7.5 \\
8 \\
4 \\
4 \\
6\end{array}$ & $\begin{array}{l}-- \\
-- \\
-- \\
0.0 \\
0.0 \\
0.0\end{array}$ & $\begin{array}{l}-- \\
30 \\
-- \\
-- \\
--\end{array}$ & $\begin{array}{l}-- \\
-- \\
-- \\
-- \\
--\end{array}$ \\
\hline Dc42-6 & $\begin{array}{l}2-3-56 \\
3-2-59 \\
5-4-67 \\
7-28-75 \\
7-22-76 \\
4-20-77\end{array}$ & $\begin{array}{l}7.3 \\
7.5 \\
-7.6 \\
7.6 \\
7.5\end{array}$ & $\begin{array}{l}-- \\
-- \\
-- \\
-- \\
--\end{array}$ & $\begin{array}{r}0 \\
-- \\
1 \overline{126} \\
167 \\
142\end{array}$ & $\begin{array}{l}0.33 \\
0.4 \\
-0 . \\
0.64 \\
0.52 \\
1.98\end{array}$ & $\begin{array}{l}0.0 \\
-- \\
0- \\
0.00 \\
0.00 \\
0.01\end{array}$ & $\begin{array}{l}-- \\
-- \\
-- \\
-- \\
--\end{array}$ & $\begin{array}{c}10 \\
9.0 \\
9 \\
9 \\
10 \\
11\end{array}$ & $\begin{array}{l}-- \\
-- \\
-- \\
0.0 \\
0.0 \\
0.0\end{array}$ & $\begin{array}{l}-\overline{14} \\
-- \\
-- \\
--\end{array}$ & $\begin{array}{l}-- \\
-- \\
-- \\
-- \\
--\end{array}$ \\
\hline
\end{tabular}

1 as $\mathrm{CaCO}_{3}$. 


\begin{tabular}{|c|c|c|c|c|c|c|c|c|c|c|}
\hline $\begin{array}{l}\text { Silica } \\
\left(\mathrm{SiO}_{2}\right)\end{array}$ & $\begin{array}{l}\text { Ni- } \\
\text { trate } \\
\text { Ni- } \\
\text { trogen } \\
\left(\mathrm{NO}_{3}-\mathrm{N}\right)\end{array}$ & $\begin{array}{l}\text { Sul- } \\
\text { fate } \\
\left(\mathrm{SO}_{4}\right)\end{array}$ & $\begin{array}{l}\text { Total } \\
\text { hard- } \\
\text { ness } \\
\text { as } \\
\mathrm{CaCO}_{3}\end{array}$ & $\begin{array}{l}\text { Non- } \\
\text { car- } \\
\text { bon- } \\
\text { ate } \\
\text { hard- } \\
\text { ness }\end{array}$ & $\begin{array}{l}\text { Bi- } \\
\text { car- } \\
\text { bon- } \\
\text { ate } \\
\left(\mathrm{HCO}_{3}\right)\end{array}$ & $\begin{array}{l}\text { Free } \\
\text { car- } \\
\text { bonic } \\
\text { acid } \\
\left(\mathrm{CO}_{2}\right)\end{array}$ & $\begin{array}{l}\text { Tur- } \\
\text { bid- } \\
\text { ity }\end{array}$ & $\begin{array}{l}\text { Alka- } \\
\text { lin- } \\
\text { ity }\end{array}$ & Other & Source \\
\hline -- & -- & -- & -- & -- & -- & -- & -- & -- & -- & W \\
\hline-- & 0.0 & 3 & 40 & -- & 69 & 10 & 20 & 5 & -- & M \\
\hline-- & -- & -- & -- & -- & -- & -- & -- & -- & -- & W \\
\hline-- & -- & -- & -- & -- & -- & -- & -- & -- & -- & \\
\hline-- & 1.83 & 4.2 & 13 & 0 & 23 & -- & -- & -- & -- & \\
\hline-- & -- & -- & -- & -- & -- & -- & -- & -- & COD : 19 & DNREC \\
\hline-- & -- & $=-$ & $=-$ & -- & -- & -- & -- & -- & -- & W \\
\hline-- & 0.90 & 0 & 10 & -- & 9 & 5 & 3 & 3 & -- & M \\
\hline-- & -- & -- & -- & -- & -- & -- & -- & -- & -- & \\
\hline-- & -- & -- & -- & -- & -- & -- & -- & -- & COD : 10 & DNREC \\
\hline-- & 0.0 & 2 & 34 & -- & 69 & 3 & 5 & 30 & -- & \\
\hline-- & -- & -- & -- & -- & -- & -- & -- & -- & COD $:<5$ & DNREC \\
\hline-- & 0.90 & 6.0 & 14 & -- & 9 & 5.0 & 5 & 3 & -- & $\mathrm{R}, \mathrm{M}$ \\
\hline-- & -- & -- & 10 & 4 & -- & 28 & 3 & 6 & -- & BGB \\
\hline-- & -- & -- & 13 & -- & -- & 20 & -- & -- & -- & M \\
\hline-- & 2.26 & 0 & 11 & -- & -- & 4.0 & 5 & 5 & $\mathrm{~K}: 7$ & \\
\hline-- & 2.6 & $<5.0$ & 22 & -- & -- & -- & -- & -- & BOD : $<2.4, C O D: 0$ & DNREC \\
\hline-- & -- & -- & -- & -- & -- & -- & -- & -- & -- & W \\
\hline & & & & & & & & & & \\
\hline-- & 0.0 & 13 & 14 & 0 & -- & 9 & 1.5 & 85 & -- & BGB \\
\hline
\end{tabular}

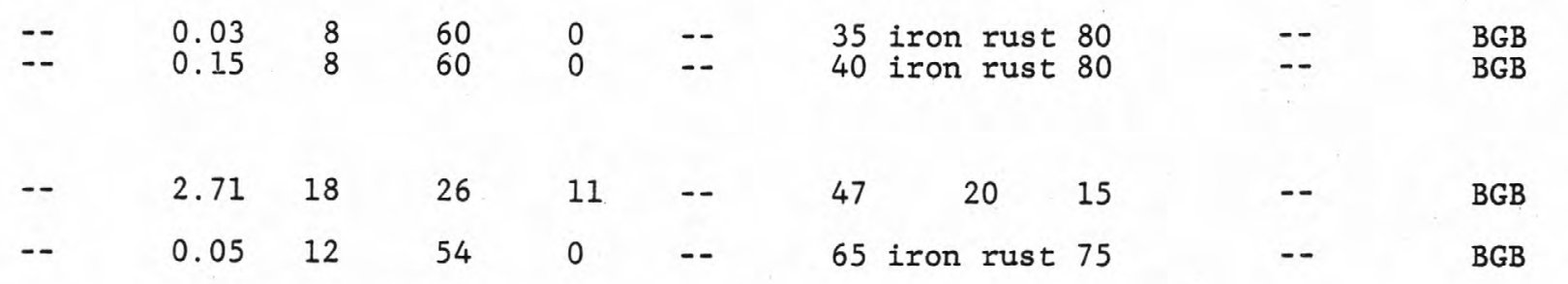

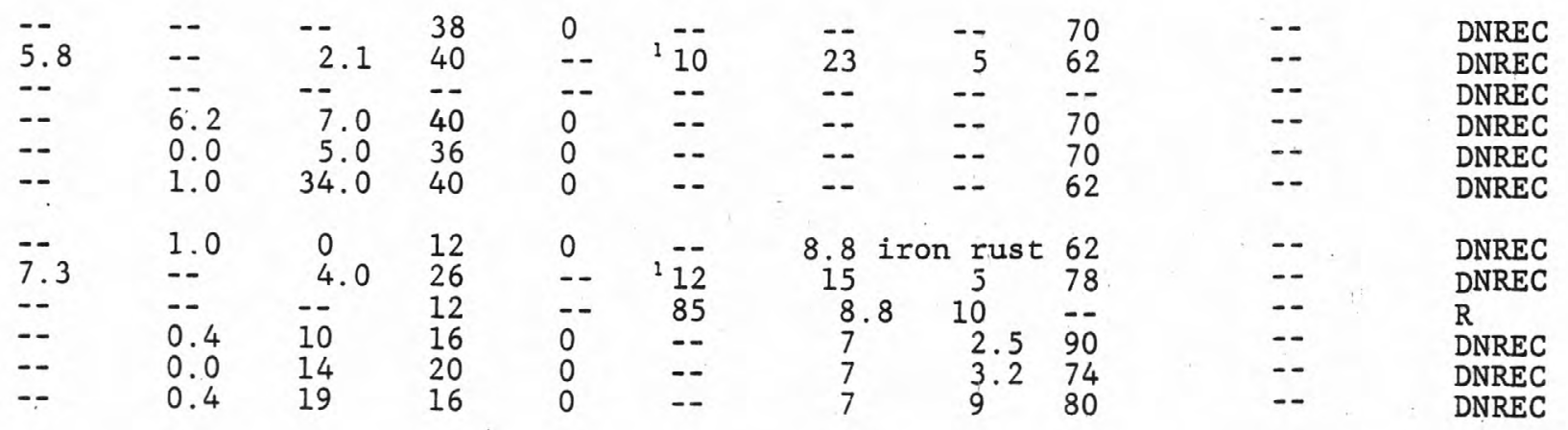


TABLE 5.--Chemical analyses of water from the Potomac Formation in New Castle CountyContinued

\begin{tabular}{|c|c|c|c|c|c|c|c|c|c|c|c|}
\hline We11 & $\begin{array}{l}\text { Date } \\
\text { s am- } \\
\text { pled }\end{array}$ & PH & $\begin{array}{l}\text { Spe- } \\
\text { cific } \\
\text { con- } \\
\text { duc- } \\
\text { tance }\end{array}$ & $\begin{array}{l}\text { Total } \\
\text { dis- } \\
\text { solved } \\
\text { solids }\end{array}$ & $\begin{array}{l}\text { Iron } \\
(\mathrm{Fe})\end{array}$ & $\begin{array}{l}\text { Man- } \\
\text { ga- } \\
\text { nese } \\
(\mathrm{Mn})\end{array}$ & $\begin{array}{l}\text { Sodi- } \\
\text { um } \\
(\mathrm{Na})\end{array}$ & $\begin{array}{l}\text { Chlo- } \\
\text { ride } \\
\text { (C1) }\end{array}$ & $\begin{array}{l}\text { Flo- } \\
\text { ride } \\
\text { (F) }\end{array}$ & $\begin{array}{l}\text { Cal- } \\
\text { cium } \\
\text { (Ca) }\end{array}$ & $\begin{array}{l}\text { Mag- } \\
\text { ne- } \\
\text { sium } \\
(\mathrm{Mg})\end{array}$ \\
\hline \multicolumn{12}{|l|}{ Getty } \\
\hline Dc43-1 & $\begin{array}{l}7-6-55 \\
6-8-55\end{array}$ & $\begin{array}{l}6.9 \\
--\end{array}$ & 144 & -- & -- & -- & 26 & $\begin{array}{l}3.5 \\
3.5\end{array}$ & -- & $=$ & -- \\
\hline Dc44-1 & $7-6-55$ & 6.4 & 53.3 & -- & -- & -- & 5 & 2.5 & -- & -- & -- \\
\hline Dc51-3 & $\begin{array}{l}3-11-66 \\
4-7-66\end{array}$ & -- & -- & $=$ & $=$ & $=-$ & -- & $\begin{array}{l}11 \\
21\end{array}$ & $=$ & -- & $=$ \\
\hline De51-7 & $\begin{array}{l}10-6-55 \\
10-7-55 \\
5-11-59 \\
5-4-67 \\
7-25-75 \\
7-15-76 \\
4-22-77\end{array}$ & $\begin{array}{l}6.6 \\
6.7 \\
6.85 \\
-- \\
6.7 \\
6.8 \\
7.0\end{array}$ & $\begin{array}{l}-- \\
-- \\
-- \\
-- \\
-- \\
--\end{array}$ & $\begin{array}{l}148 \\
-- \\
-- \\
-\overline{117} \\
92 \\
115\end{array}$ & $\begin{array}{l}3.2 \\
2.8 \\
3.4 \\
-- \\
5.5 \\
6.1 \\
5.6\end{array}$ & $\begin{array}{l}0.1 \\
0.1 \\
-- \\
-- \\
0.0 \\
0.07 \\
0.1\end{array}$ & $\begin{array}{l}-- \\
-- \\
-- \\
-- \\
--\end{array}$ & $\begin{array}{c}19 \\
19 \\
9.0 \\
17 \\
14 \\
4 \\
14\end{array}$ & $\begin{array}{l}-- \\
-- \\
-- \\
0.0 \\
0.0 \\
0.0\end{array}$ & $\begin{array}{l}-- \\
\overline{-} \\
36 \\
-- \\
-- \\
--\end{array}$ & $\begin{array}{l}-- \\
-- \\
-- \\
-- \\
-- \\
-- \\
--\end{array}$ \\
\hline De51-8 & $\begin{array}{l}2-16-56 \\
3-7-56 \\
5-5-67\end{array}$ & $\begin{array}{l}6.8 \\
6.4 \\
--\end{array}$ & $\begin{array}{l}-- \\
-- \\
--\end{array}$ & $\begin{array}{l}-- \\
-- \\
--\end{array}$ & $\begin{array}{l}4.0 \\
4.8 \\
--\end{array}$ & $\begin{array}{l}0.1 \\
0.1 \\
-.\end{array}$ & -- & $\begin{array}{l}3.4 \\
2.0 \\
9\end{array}$ & $\begin{array}{l}-- \\
--\end{array}$ & $\begin{array}{l}-- \\
--\end{array}$ & $\begin{array}{l}-- \\
--\end{array}$ \\
\hline Dc52-1 & $\begin{array}{l}7-6-54 \\
7-21-54 \\
8-2-54\end{array}$ & $\begin{array}{l}36.7 \\
47.1 \\
3 \\
6.7\end{array}$ & $\begin{array}{l}-- \\
--\end{array}$ & $\begin{array}{l}88 \\
-- \\
--\end{array}$ & $\begin{array}{l}6.0 \\
.24 \\
4.5\end{array}$ & $\begin{array}{r}0.8 \\
.1 \\
.1\end{array}$ & $\begin{array}{l}-- \\
--\end{array}$ & $\begin{array}{r}5.5 \\
16 \\
4.0\end{array}$ & -1 & $\begin{array}{l}-- \\
--\end{array}$ & $\begin{array}{l}-- \\
--\end{array}$ \\
\hline Dc52-2 & $\begin{array}{l}7-12-54 \\
7-28-75\end{array}$ & $\begin{array}{l}6.6 \\
6.9\end{array}$ & -- & $\begin{array}{r}118 \\
98\end{array}$ & $\begin{array}{r}5.3 \\
15.5\end{array}$ & 0.1 & -- & $\frac{6.5}{2}$ & $\overline{0}$ & -- & -- \\
\hline Dc52-24 & $\begin{array}{c}12-9-54 \\
12-12-54 \\
12-15-54 \\
-7-56 \\
3-2-59 \\
3-11-66 \\
1-6-67 \\
7-25-75 \\
7-16-76 \\
4-20-77 \\
1-3-79\end{array}$ & $\begin{array}{l}6.6 \\
6.7 \\
6.6 \\
6.6 \\
7.3 \\
-- \\
- \\
6.7 \\
6.8 \\
6.8 \\
8.0\end{array}$ & $\begin{array}{l}-- \\
-- \\
-- \\
-- \\
-- \\
-- \\
-- \\
-- \\
-- \\
--\end{array}$ & $\begin{array}{c}78 \\
82 \\
88 \\
96 \\
-- \\
-- \\
-- \\
80 \\
99 \\
97 \\
--\end{array}$ & $\begin{array}{c}3.0 \\
3.3 \\
2.8 \\
2.8 \\
0.9 \\
-- \\
-- \\
10.0 \\
8.34 \\
16.1 \\
2.2\end{array}$ & $\begin{array}{l}0 \\
0 \\
0 \\
0 \\
-- \\
-- \\
-- \\
0.02 \\
0.05 \\
0.06 \\
--\end{array}$ & $\begin{array}{l}-- \\
-- \\
-- \\
-- \\
-- \\
-- \\
-- \\
--\end{array}$ & $\begin{array}{l}4.0 \\
4.0 \\
4.0 \\
4 \\
9.0 \\
5 \\
1 \\
1 \\
2 \\
1 \\
14\end{array}$ & $\begin{array}{l}-- \\
-- \\
-- \\
-- \\
-- \\
-- \\
0 \\
0 \\
0 \\
--\end{array}$ & $\begin{array}{l}13 \\
14 \\
13 \\
-- \\
-- \\
-- \\
-- \\
-- \\
-- \\
--\end{array}$ & $\begin{array}{r}2.5 \\
1.6 \\
2.1 \\
12.6 \\
16 \\
-- \\
-- \\
-- \\
=16\end{array}$ \\
\hline Dc53-7 & $10-1-54$ & 7.3 & -- & -- & -- & 0.2 & -- & 12 & -- & -- & -- \\
\hline DC53-23 & $\begin{array}{l}8-3-54 \\
8-25-54\end{array}$ & $\begin{array}{l}7.1 \\
6.5\end{array}$ & -- & $\begin{array}{l}110 \\
--\end{array}$ & $\begin{array}{l}1.4 \\
5.5\end{array}$ & $\begin{array}{l}0 \\
0.1\end{array}$ & -- & $\begin{array}{l}4.0 \\
4.0\end{array}$ & -- & -- & -- \\
\hline Eb15-2 & $\begin{array}{l}12-6-55 \\
1-5-56\end{array}$ & $\begin{array}{l}6.5 \\
6.5\end{array}$ & -- & -- & $\begin{array}{l}7.5 \\
8.2\end{array}$ & $\begin{array}{l}0.1 \\
0.1\end{array}$ & -- & $\begin{array}{l}2.5 \\
5.0\end{array}$ & -- & -- & -- \\
\hline Eb $15-4$ & $\begin{array}{l}10-21-55 \\
1-29-59 \\
3-2-59 \\
5-4-67 \\
7-25-75 \\
7-16-76 \\
4-20-77\end{array}$ & $\begin{array}{l}6.7 \\
6.8 \\
6.9 \\
-- \\
6.9 \\
6.8 \\
6.8\end{array}$ & $\begin{array}{l}-- \\
-- \\
-- \\
-- \\
-- \\
-- \\
--\end{array}$ & $\begin{array}{l}116 \\
-- \\
-- \\
-- \\
102 \\
107 \\
119\end{array}$ & $\begin{array}{l}2.0 \\
7.0 \\
0.7 \\
-- \\
4.8 \\
6.46 \\
9.76\end{array}$ & $\begin{array}{l}.0 \\
\therefore- \\
-- \\
0.0 \\
0.05 \\
0.05\end{array}$ & $\begin{array}{ll}-- & 1 \\
-- & 1 \\
-- & 1 \\
-- & 1 \\
-- & \\
-- & \end{array}$ & $\begin{array}{c}10.0 \\
16 \\
9.0 \\
12.0 \\
9.0 \\
7 \\
9\end{array}$ & $\begin{array}{l}-- \\
-- \\
-- \\
-- \\
0.0 \\
0.0 \\
0.0\end{array}$ & $\begin{array}{l}-- \\
-- \\
-- \\
-- \\
--\end{array}$ & 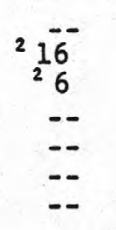 \\
\hline Ec12-2 & $\begin{array}{l}4-7-66 \\
1-6-67\end{array}$ & $=-$ & -- & -- & -- & -- & -- & $\begin{array}{l}9 \\
7\end{array}$ & -- & -- & -- \\
\hline Ec12-3 & $\begin{array}{l}11-1-54 \\
1-6-67\end{array}$ & $\begin{array}{l}7.0 \\
-- \\
\end{array}$ & -- & $\begin{array}{l}126 \\
--\end{array}$ & $\begin{array}{l}2.8 \\
--\end{array}$ & 0.1 & $=$ & 11.0 & 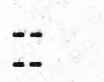 & -- & -- \\
\hline
\end{tabular}




\begin{tabular}{|c|c|c|c|c|c|c|c|c|c|c|}
\hline $\begin{array}{l}\text { Silica } \\
\left(\mathrm{SiO}_{2}\right)\end{array}$ & $\begin{array}{l}\text { Ni- } \\
\text { trate } \\
\text { Ni- } \\
\text { trogen } \\
\left(\mathrm{NO}_{3}-\mathrm{N}\right)\end{array}$ & $\begin{array}{l}\text { Sul- } \\
\text { fate } \\
\left(\mathrm{SO}_{4}\right)\end{array}$ & $\begin{array}{l}\text { Total } \\
\text { hard- } \\
\text { ness } \\
\text { as } \\
\mathrm{CaCO}_{3}\end{array}$ & $\begin{array}{l}\text { Non- } \\
\text { car- } \\
\text { bon- } \\
\text { ate } \\
\text { hard- } \\
\text { ness }\end{array}$ & $\begin{array}{l}\mathrm{Bi}- \\
\text { car- } \\
\text { bon- } \\
\text { ate } \\
\left(\mathrm{HCO}_{3}\right)\end{array}$ & $\begin{array}{l}\text { Free } \\
\text { car- } \\
\text { bonic } \\
\text { acid } \\
\left(\mathrm{CO}_{2}\right)\end{array}$ & $\begin{array}{l}\text { Tur- } \\
\text { bid- } \\
\text { ity }\end{array}$ & $\begin{array}{l}\text { Alka- } \\
\text { lin- } \\
\text { ity }\end{array}$ & Other & Source \\
\hline$=-$ & $\begin{array}{l}0 \\
0\end{array}$ & $\begin{array}{l}5.0 \\
4.0\end{array}$ & $\begin{array}{l}22 \\
14\end{array}$ & $\begin{array}{l}0 \\
0\end{array}$ & 83 & $=$ & $=$ & $=$ & $=$ & $\stackrel{R}{\mathrm{R}}$ \\
\hline-- & 0 & 4.0 & 14 & 0 & 21 & -- & -- & -- & -- & $\mathbf{R}$ \\
\hline$=$ & $\because-$ & $=$ & -- & $=$ & $=$ & $=$ & $=$ & $=$ & $=$ & $\begin{array}{l}W \\
W\end{array}$ \\
\hline $\begin{array}{l}-- \\
-- \\
5.8 \\
-- \\
-- \\
--\end{array}$ & $\begin{array}{l}- \\
- \\
-- \\
- \\
0.6 \\
0.0 \\
0.2\end{array}$ & \begin{tabular}{c}
$\cdots$ \\
$\cdots 1.6$ \\
\hdashline 9.0 \\
5.0 \\
14
\end{tabular} & $\begin{array}{l}52 \\
52 \\
50 \\
-- \\
56 \\
50 \\
54\end{array}$ & $\begin{array}{c}0 \\
--- \\
-- \\
0 \\
0 \\
0\end{array}$ & $\begin{array}{r}82 \\
80 \\
24 \\
-- \\
-- \\
-- \\
--\end{array}$ & $\begin{array}{ll}35 & i \\
31 & \\
36 \\
-- \\
35 & i \\
37 & i \\
15 & i\end{array}$ & $\begin{array}{l}\text { iron rust } \\
\overline{10} \\
-- \\
\text { iron rust } \\
\text { iron rust } \\
\text { iron rust }\end{array}$ & $\begin{array}{l}80 \\
-72 \\
--- \\
80 \\
75 \\
73\end{array}$ & $\begin{array}{l}-- \\
-- \\
-- \\
-- \\
-- \\
--\end{array}$ & $\begin{array}{l}\text { DNREC } \\
\text { R } \\
\text { DNREC } \\
\text { S, } W \\
\text { DNREC } \\
\text { DNREC } \\
\text { DNREC }\end{array}$ \\
\hline $\begin{array}{l}-- \\
-- \\
--\end{array}$ & $\begin{array}{l}-- \\
--\end{array}$ & $=$ & $\begin{array}{l}44 \\
42 \\
--\end{array}$ & $=$ & $\begin{array}{l}62 \\
62 \\
--\end{array}$ & $\begin{array}{l}22 \\
44 \\
--\end{array}$ & $\begin{array}{l}-- \\
-- \\
--\end{array}$ & $\begin{array}{l}-- \\
--\end{array}$ & $\begin{array}{l}-- \\
--\end{array}$ & $\begin{array}{l}\mathrm{R} \\
\mathrm{R} \\
\mathrm{S}\end{array}$ \\
\hline $\begin{array}{l}6.0 \\
5.6 \\
7.0\end{array}$ & $\begin{array}{l}-- \\
--\end{array}$ & $\begin{array}{l}-- \\
--\end{array}$ & $\begin{array}{l}34 \\
28 \\
40\end{array}$ & -- & $\begin{array}{l}68 \\
-\overline{82}\end{array}$ & $\begin{array}{l}30: 8 \\
15.4 \\
35.2\end{array}$ & $\begin{array}{ll}8 & =- \\
4 & -- \\
2 & 25\end{array}$ & 100 & $\begin{array}{l}-- \\
--\end{array}$ & $\begin{array}{l}\mathrm{R} \\
\mathrm{R} \\
\mathrm{R}\end{array}$ \\
\hline $\begin{array}{l}6.0 \\
--\end{array}$ & $\overline{1.0}$ & $\overline{12} .0$ & $\begin{array}{l}44 \\
48\end{array}$ & $\begin{array}{l}0 \\
0\end{array}$ & 80 & $\begin{array}{l}28.6 \\
15 i\end{array}$ & $\begin{array}{l}6-- \\
\text { ifon rust }\end{array}$ & $\begin{aligned} & 80 \\
= & 55\end{aligned}$ & $=$ & $\begin{array}{l}\mathrm{R} \\
\text { DNREC }\end{array}$ \\
\hline $\begin{array}{l}6.0 \\
6.0 \\
6.0 \\
6.0 \\
7.4 \\
-- \\
-- \\
-- \\
-- \\
--\end{array}$ & $\begin{array}{l}-- \\
-- \\
-- \\
-- \\
2.1 \\
-- \\
-- \\
2 \\
3 \\
8 \\
--\end{array}$ & $\begin{array}{l}4.9 \\
4.3 \\
4.9 \\
4.9 \\
-- \\
-- \\
-- \\
-- \\
-- \\
--\end{array}$ & $\begin{array}{l}42 \\
40 \\
40 \\
40 \\
22 \\
-- \\
-- \\
44 \\
44 \\
44 \\
30\end{array}$ & $\begin{array}{c}-- \\
-- \\
-- \\
0 \\
-- \\
-- \\
-- \\
0 \\
0 \\
0 \\
--\end{array}$ & $\begin{array}{l}65 \\
68 \\
70 \\
2.1 \\
26 \\
-- \\
=- \\
=- \\
-- \\
--\end{array}$ & 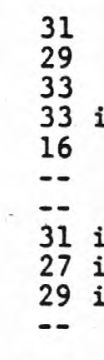 & $\begin{array}{l}-- \\
35 \\
35 \\
\text { iron rust } \\
3 \\
-- \\
\text { iron rust } \\
\text { iron rust } \\
\text { iron rust } \\
\text {-- }\end{array}$ & $\begin{array}{l}-- \\
-- \\
70 \\
70 \\
86 \\
-- \\
-- \\
60 \\
70 \\
60 \\
82\end{array}$ & $\begin{array}{c}-- \\
-- \\
-- \\
-- \\
-- \\
-- \\
-- \\
-\overline{-} \\
P O \\
-0.1\end{array}$ & $\begin{array}{l}\mathrm{R} \\
\mathrm{R} \\
\mathrm{R} \\
\text { DNREC } \\
\text { DNREC } \\
\mathrm{W} \\
\mathrm{W} \\
\text { DNREC } \\
\text { DNREC } \\
\text { DNREC } \\
\text { DNREC }\end{array}$ \\
\hline-- & -- & -- & 22.0 & 0 & -- & 8.8 & muddy & 85 & -- & W \\
\hline $\begin{array}{l}7.0 \\
7.0\end{array}$ & $=-$ & $\begin{array}{l}56 \\
38\end{array}$ & $\begin{array}{l}0 \\
0\end{array}$ & $\begin{array}{l}84 \\
70\end{array}$ & $\begin{array}{l}13.2 \\
44\end{array}$ & $\begin{array}{l}55 \\
10\end{array}$ & $\begin{array}{l}84 \\
--\end{array}$ & $=-$ & $=$ & $\begin{array}{l}\mathrm{R} \\
\mathrm{R}\end{array}$ \\
\hline$=$ & $=$ & $=$ & $\begin{array}{l}34 \\
34\end{array}$ & $=$ & $\begin{array}{l}60 \\
63\end{array}$ & $\begin{array}{l}40 \\
44\end{array}$ & 150 & $\begin{array}{l}-- \\
--\end{array}$ & $=$ & $\begin{array}{l}\mathrm{R} \\
\mathrm{R}\end{array}$ \\
\hline $\begin{array}{l}-- \\
2.0 \\
5.3 \\
-- \\
-- \\
--\end{array}$ & $\begin{array}{l}-- \\
-- \\
-- \\
- \\
0.4 \\
0.0 \\
0.1\end{array}$ & $\begin{array}{r}7.0 \\
1.6 \\
-8 \\
4 \\
8.0 \\
12.0\end{array}$ & $\begin{array}{l}44 \\
58 \\
40 \\
-- \\
44 \\
40 \\
40\end{array}$ & $\begin{array}{c}0 \\
-- \\
-- \\
0 \\
--\end{array}$ & $\begin{array}{l}82 \\
-- \\
-- \\
-- \\
-- \\
--\end{array}$ & $\begin{array}{l}31 \\
22 \\
30 \\
-- \\
26 \\
26 i \\
35\end{array}$ & $\begin{array}{l}\text { iron rust } \\
5 \\
5 \\
-- \\
\text { iron rust } \\
\text { iron rust } \\
16\end{array}$ & $\begin{array}{l}-7- \\
66 \\
74 \\
82.5 \\
75 \\
73 \\
70\end{array}$ & $\begin{array}{l}-- \\
=- \\
-- \\
=- \\
--\end{array}$ & $\begin{array}{l}\text { R } \\
\text { DNREC } \\
\text { DNREC } \\
\text { S, }, \\
\text { DNREC } \\
\text { DNREC } \\
\text { DNREC }\end{array}$ \\
\hline$=$ & $=$ & -- & $=$ & -- & $=$ & $=$ & $=$ & $=$ & $=$ & $\begin{array}{l}\mathrm{W} \\
\mathrm{W}\end{array}$ \\
\hline $\begin{array}{l}7.0 \\
--\end{array}$ & $=$ & $\begin{array}{l}5.3 \\
--\end{array}$ & $\begin{array}{l}22 \\
--\end{array}$ & $=$ & 90 & 18 & 30 & -- & $=-$ & $\underset{\mathrm{W}}{\mathrm{R}}$ \\
\hline
\end{tabular}


TABLE 5.--Chemical analyses of water from the Potomac Formation in New Castle CountyContinued

\begin{tabular}{|c|c|c|c|c|c|c|c|c|c|c|c|}
\hline We11 & $\begin{array}{l}\text { Date } \\
\text { s am- } \\
\text { pled }\end{array}$ & $\mathrm{PH}$ & $\begin{array}{l}\text { Spe- } \\
\text { cific } \\
\text { con- } \\
\text { duc- } \\
\text { tance }\end{array}$ & $\begin{array}{l}\text { Total } \\
\text { dis- } \\
\text { solved } \\
\text { solids }\end{array}$ & $\begin{array}{l}\text { Iron } \\
(\mathrm{Fe})\end{array}$ & $\begin{array}{l}\text { Man- } \\
\text { ga- } \\
\text { nese } \\
(M n)\end{array}$ & $\begin{array}{l}\text { Sodi- } \\
\text { um } \\
\text { (Na) }\end{array}$ & $\begin{array}{l}\text { Chlo- } \\
\text { ride } \\
\text { (C1) }\end{array}$ & $\begin{array}{l}\text { Flo- } \\
\text { ride } \\
\text { (F) }\end{array}$ & $\begin{array}{l}\text { Cal- } \\
\text { cium } \\
\text { (Ca) }\end{array}$ & $\begin{array}{l}\text { Mag- } \\
\text { ne- } \\
\text { sium } \\
(\mathrm{Mg})\end{array}$ \\
\hline
\end{tabular}

\section{Getty}

\begin{tabular}{|c|c|c|c|c|c|c|c|c|c|c|c|}
\hline Ec12-15 & $\begin{array}{l}8-19-54 \\
9-2-54\end{array}$ & $\begin{array}{l}6.6 \\
6.9\end{array}$ & -- & $\begin{array}{r}84 \\
116\end{array}$ & $\begin{array}{l}5.2 \\
4.15\end{array}$ & $\begin{array}{l}0.1 \\
0.0\end{array}$ & $=-$ & $\begin{array}{r}5.5 \\
11.5\end{array}$ & -- & -- & $=-$ \\
\hline Ec12-20 & $\begin{array}{l}-1-55 \\
1-29-59 \\
5-4-67 \\
7-28-75 \\
9-27-76 \\
1-3-79\end{array}$ & $\begin{array}{l}7.0 \\
6.7 \\
-- \\
7.0 \\
7.0 \\
7.7\end{array}$ & $\begin{array}{l}-- \\
=- \\
=- \\
-- \\
181\end{array}$ & $\begin{array}{l}122 \\
-- \\
-- \\
-- \\
105 \\
--\end{array}$ & $\begin{array}{l}1.44 \\
2.1 \\
--. \\
4.3 \\
3.73 \\
2.2\end{array}$ & $\begin{array}{l}0.0 \\
-- \\
-- \\
0.05 \\
0.08 \\
--\end{array}$ & $\begin{array}{l}-- \\
-- \\
-- \\
-- \\
--\end{array}$ & $\begin{array}{r}8 \\
12 \\
13 \\
11 \\
14 \\
13\end{array}$ & $\begin{array}{l}-- \\
-- \\
-- \\
0.0 \\
0.0 \\
--\end{array}$ & $\begin{array}{l}5 \overline{20} \\
-- \\
\overline{13} \\
--\end{array}$ & $\begin{array}{l}-\overline{8} \\
-- \\
-\overline{5} \\
--\end{array}$ \\
\hline Ec13-5 & $1-6-67$ & -- & -- & -- & -- & -- & -- & 2 & -- & -- & -- \\
\hline Ecl3-6 & $\begin{array}{l}8-25-54 \\
1-24-55 \\
1-26-55 \\
1-31-55 \\
2-10-55 \\
-\quad-56 \\
3-2-59 \\
6-3-66 \\
1-6-67 \\
5-4-67 \\
7-25-75 \\
7-15-76 \\
1-3-79\end{array}$ & $\begin{array}{l}6.5 \\
7.1 \\
7.1 \\
7.1 \\
7.3 \\
7.3 \\
7.3 \\
-- \\
-- \\
-- \\
7.2 \\
7.2 \\
8.0\end{array}$ & $\begin{array}{l}-- \\
-- \\
-- \\
-- \\
-- \\
-- \\
-- \\
-- \\
-- \\
-- \\
179\end{array}$ & $\begin{array}{c}98 \\
-- \\
-- \\
-- \\
\overline{-} \\
132 \\
-- \\
-- \\
-- \\
-- \\
144 \\
111 \\
--\end{array}$ & $\begin{array}{l}5.5 \\
1.3 \\
1.2 \\
1.2 \\
1.1 \\
-- \\
0.9 \\
-- \\
-- \\
-- \\
5.94 \\
1.65 \\
8.0\end{array}$ & $\begin{array}{l}0.1 \\
0.0 \\
0.0 \\
0.0 \\
0.0 \\
0.0 \\
-- \\
-- \\
-- \\
-- \\
0.03 \\
0.00 \\
--\end{array}$ & $\begin{array}{l}-- \\
-- \\
-- \\
-- \\
-- \\
-- \\
-- \\
-- \\
-- \\
-- \\
-- \\
--\end{array}$ & $\begin{array}{l}4.0 \\
9.0 \\
8.0 \\
8.5 \\
9.0 \\
9 \\
9 \\
4 \\
4 \\
9 \\
6 \\
7 \\
15\end{array}$ & $\begin{array}{l}-- \\
-- \\
-- \\
-- \\
-- \\
-- \\
-- \\
-- \\
-- \\
0.0 \\
0.0 \\
--\end{array}$ & $\begin{array}{c}-- \\
4.3 \\
3.7 \\
4.3 \\
5.7 \\
5.7 \\
516 \\
-- \\
-- \\
-- \\
-- \\
\overline{5} 17\end{array}$ & $\begin{array}{l}- \\
2.3 \\
2.1 \\
1.8 \\
1.4 \\
-- \\
-- \\
-- \\
-- \\
-- \\
-- \\
-- \\
--\end{array}$ \\
\hline Ec14-1 & $\begin{array}{l}9-24-54 \\
10-8-54 \\
10-26-54\end{array}$ & $\begin{array}{r}7.4 \\
7.1 \\
+--\end{array}$ & $\begin{array}{l}-- \\
-- \\
--\end{array}$ & $\begin{array}{r}186 \\
-- \\
--\end{array}$ & $\begin{array}{l}2.5 \\
2.0 \\
--\end{array}$ & $\begin{array}{l}0.0 \\
0.0 \\
--\end{array}$ & $\begin{array}{l}-- \\
--\end{array}$ & $\begin{array}{l}39.5 \\
43 \\
39\end{array}$ & $=-$ & $\begin{array}{l}-- \\
--\end{array}$ & $\overline{--}$ \\
\hline Ec14-7 & $\begin{array}{l}-\quad-55 \\
1-29-59 \\
5-9-67 \\
7-25-75 \\
7-14-76 \\
4-18-77 \\
1-3-79\end{array}$ & $\begin{array}{l}7.0 \\
7.0 \\
-- \\
7.5 \\
7.3 \\
7.5 \\
7.8\end{array}$ & $\begin{array}{c}-- \\
-- \\
=- \\
-- \\
-- \\
156\end{array}$ & $\begin{array}{r}158 \\
-- \\
-- \\
132 \\
155 \\
158 \\
--\end{array}$ & \begin{tabular}{l}
1.16 \\
1.6 \\
\hdashline 1.28 \\
1.56 \\
1.9
\end{tabular} & $\begin{array}{l}0.0 \\
-- \\
-- \\
0.01 \\
0.00 \\
0.02 \\
--\end{array}$ & $\begin{array}{l}-- \\
-- \\
-- \\
-- \\
-- \\
--\end{array}$ & $\begin{array}{l}22 \\
22 \\
21 \\
19 \\
17 \\
17 \\
15\end{array}$ & $\begin{array}{l}-- \\
-- \\
-- \\
0.0 \\
0.0 \\
0.0 \\
--\end{array}$ & $\begin{array}{l}\overline{-} \\
514 \\
\overline{-} \\
\overline{-} \\
\overline{-} \\
{ }^{111}\end{array}$ & $\begin{array}{l}-\overline{5} \\
-- \\
-- \\
-- \\
-\overline{5}\end{array}$ \\
\hline
\end{tabular}

Glendale

\begin{tabular}{|c|c|c|c|c|c|c|c|c|c|c|c|}
\hline Dc31-10 & $6--73$ & 5.8 & -- & -- & 0.03 & 0.11 & 4 & 4 & 0.0 & -- & -- \\
\hline Dc31-24 & $2-19-76$ & 5.45 & 47.5 & -- & 0.02 & -- & -- & 5.0 & $<.1$ & -- & -- \\
\hline Dc $31-26$ & $11-30-73$ & 6.8 & -- & -- & 5.7 & 0.05 & -- & 4 & 0.0 & -- & -- \\
\hline Dc31-27 & $12-11-73$ & 6.6 & -- & -- & 1.5 & 0.03 & -- & 3 & 0.0 & -- & $-\cdots$ \\
\hline \multicolumn{12}{|l|}{ Goodrich $^{6}$} \\
\hline Ea33-1 & $11-20-66$ & 6.3 & -- & 61 & 9.2 & 0.15 & -- & 1 & -- & -- & -- \\
\hline Ea33-4 & $9-30-66$ & 6.1 & -- & 158 & 9.2 & 0.1 & -- & 1 & -- & -- & - \\
\hline \multicolumn{5}{|l|}{ Lums Pond } & ${ }^{\circ}$ & & & & & & \\
\hline$E b 22-11$ & $11-1-74$ & 6.6 & -- & -- & 3.3 & 0.0 & -- & 2 & 0.0 & -- & -- \\
\hline
\end{tabular}




\begin{tabular}{|c|c|c|c|c|c|c|c|c|c|c|}
\hline $\begin{array}{l}\text { Silica } \\
\left(\mathrm{SiO}_{2}\right)\end{array}$ & $\begin{array}{l}\text { Ni- } \\
\text { trate } \\
\text { Ni- } \\
\text { trogen } \\
\text { (NO, }-\mathrm{N})\end{array}$ & $\begin{array}{l}\text { Sul- } \\
\text { fate } \\
\left(\mathrm{SO}_{4}\right)\end{array}$ & $\begin{array}{l}\text { Total } \\
\text { hard- } \\
\text { ness } \\
\text { as } \\
\mathrm{CaCO}_{3}\end{array}$ & $\begin{array}{l}\text { Non- } \\
\text { car- } \\
\text { bon- } \\
\text { ate } \\
\text { hard- } \\
\text { ness }\end{array}$ & $\begin{array}{l}\text { Bi- } \\
\text { car- } \\
\text { bon- } \\
\text { ate } \\
\text { (HCO,) }\end{array}$ & $\begin{array}{l}\text { Free } \\
\text { car- } \\
\text { bonic } \\
\text { acid } \\
\left(\mathrm{CO}_{2}\right)\end{array}$ & $\begin{array}{l}\text { Tur- } \\
\text { bid- } \\
\text { ity }\end{array}$ & $\begin{array}{l}\text { Alka- } \\
\text { lin- } \\
\text { ity }\end{array}$ & Other & Source \\
\hline $\begin{array}{l}6.0 \\
7.0\end{array}$ & $=$ & $=$ & $\begin{array}{l}44 \\
32\end{array}$ & $\overline{0}$ & $\begin{array}{l}61.5 \\
88\end{array}$ & $\begin{array}{l}30.8 \\
22\end{array}$ & $\begin{array}{r}50 \\
200\end{array}$ & $=$ & $=$ & $\begin{array}{l}\mathbf{R} \\
\mathbf{R}\end{array}$ \\
\hline $\begin{array}{l}7.1 \\
7.1 \\
- \\
8.0\end{array}$ & $\begin{array}{l}-- \\
-- \\
\ddot{0.2} \\
0.0 \\
--\end{array}$ & $\begin{array}{l}\overline{4} .0 \\
\overline{7} \\
9 \\
-.\end{array}$ & $\begin{array}{l}24 \\
28 \\
-32 \\
32 \\
22\end{array}$ & $\begin{array}{r}-- \\
-- \\
- \\
0 \\
0 \\
--\end{array}$ & $\begin{array}{l}- \\
- \\
- \\
- \\
-\end{array}$ & $\begin{array}{l}22 \\
28 \\
-18 \\
18 \\
18 \\
--\end{array}$ & $\begin{array}{l}5 \\
5 \\
-- \\
\text { rust } \\
25 \\
--\end{array}$ & $\begin{array}{l}90 \\
70 \\
-- \\
85 \\
85 \\
81\end{array}$ & $\begin{array}{l}-- \\
-\therefore \\
- \\
- \\
-\end{array}$ & $\begin{array}{l}\text { DNREC } \\
\text { DNREC } \\
\text { S } \\
\text { DNREC } \\
\text { DNREC } \\
\text { DNREC }\end{array}$ \\
\hline-- & -- & -. & -- & -- & -- & -- & -- & - & -- & $\mathbf{s}$ \\
\hline $\begin{array}{l}7.0 \\
6.0 \\
6.0 \\
6.0 \\
6.0 \\
6.0 \\
7.4 \\
-\therefore \\
-\therefore \\
-- \\
-- \\
8.3\end{array}$ & $\begin{array}{l}-- \\
-- \\
-- \\
-- \\
-- \\
-- \\
-- \\
-- \\
0.3 \\
0.0 \\
--\end{array}$ & $\begin{array}{l}10 \\
10 \\
9.5 \\
7.3 \\
4.9 \\
4.9 \\
2.1 \\
-- \\
-- \\
12 \\
12 \\
--\end{array}$ & $\begin{array}{l}38.0 \\
20 \\
18 \\
18 \\
20 \\
20 \\
22 \\
-- \\
-- \\
24 \\
24 \\
26\end{array}$ & $\begin{array}{c}0 \\
-- \\
-- \\
-- \\
-0 \\
-\therefore \\
-\therefore \\
-- \\
0 \\
0 \\
--\end{array}$ & $\begin{array}{l}-- \\
90 \\
92 \\
90 \\
92 \\
1.4 \\
56 \\
-- \\
-- \\
-- \\
-- \\
59\end{array}$ & \begin{tabular}{l}
44.0 \\
13 \\
13 \\
13 \\
10 \\
10.1 \\
16 \\
\hdashline- \\
-- \\
18 iron \\
18 \\
--
\end{tabular} & $\begin{array}{c}10 \\
0 \\
0 \\
0 \\
0 \\
0 \\
3 \\
-- \\
-- \\
-- \\
\text { rust } \\
10 \\
--\end{array}$ & $\begin{array}{l}70.0 \\
-- \\
=- \\
-- \\
92.5 \\
86 \\
-- \\
-- \\
95 \\
88 \\
81\end{array}$ & 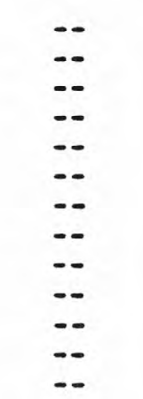 & $\begin{array}{l}\text { BGB } \\
\text { R } \\
\text { R } \\
\text { R } \\
\text { R } \\
\text { DNREC } \\
\text { DNREC } \\
\text { W } \\
\text { W } \\
\text { S } \\
\text { DNREC } \\
\text { DNREC } \\
\text { DNREC }\end{array}$ \\
\hline $\begin{array}{l}7.0 \\
7.0 \\
-.\end{array}$ & $\begin{array}{l}-- \\
--\end{array}$ & $\begin{array}{l}20.6 \\
21 \\
---\end{array}$ & $\begin{array}{l}28 \\
24 \\
--\end{array}$ & $\begin{array}{l}-- \\
--\end{array}$ & $\begin{array}{l}85 \\
85 \\
--\end{array}$ & $\begin{array}{l}73^{7.0} \\
--\end{array}$ & $\begin{array}{l}70 \\
-- \\
--\end{array}$ & $\begin{array}{l}= \\
=-\end{array}$ & $\begin{array}{l}=- \\
--\end{array}$ & $\begin{array}{l}R \\
R \\
B G B\end{array}$ \\
\hline $\begin{array}{l}-- \\
7.5 \\
-\therefore- \\
-\therefore \\
3.7\end{array}$ & $\begin{array}{l}-. \\
\because- \\
\because- \\
0.2 \\
0.0 \\
0.1\end{array}$ & $\begin{array}{l}-- \\
9.4 \\
-- \\
10 \\
5 \\
17 \\
--\end{array}$ & $\begin{array}{l}20 \\
20 \\
- \\
20 \\
24 \\
18 \\
19\end{array}$ & $\begin{array}{r}0 \\
-- \\
- \\
0 \\
0 \\
0 \\
--\end{array}$ & $\begin{array}{l}-- \\
- \\
\therefore- \\
\therefore- \\
\therefore-\end{array}$ & $\begin{array}{l}17.0 \\
15 \\
-- \\
7 \\
13 \\
7 \\
--\end{array}$ & $\begin{array}{l}-- \\
=- \\
- \\
-- \\
- \\
-\end{array}$ & $\begin{array}{l}90 \\
74 \\
-- \\
90 \\
90 \\
87 \\
71\end{array}$ & $\begin{array}{c}\mathrm{H}_{2} \overline{\mathrm{S}}: 0 \\
-- \\
-- \\
\ddot{-} \\
\mathrm{PO}: 0.1\end{array}$ & $\begin{array}{l}\text { DNREC } \\
\text { DNREC } \\
\text { S } \\
\text { DNREC } \\
\text { DNREC } \\
\text { DNREC } \\
\text { DNREC }\end{array}$ \\
\hline
\end{tabular}

$\begin{array}{llllllllllll}-- & 0.90 & 1 & 10 & 0 & -- & 30 & 0 & 12 & \ldots & \text { BGB } \\ -- & 4.1 & 0.90 & 12.0 & -- & -- & 31.2 & -- & 5.5 & \text { other metals } & \text { DNREC } \\ -- & 0.22 & 5 & 47 & 0 & -- & 47 \text { iron rust } & 68 & -. & \text { BGB } \\ -- & 0.03 & 3 & 16 & 0 & -- & 45 & 20 & 50 & \ldots & \text { BGB } \\ & & & & & & & & & & \\ -- & -- & -- & 20 & 0 & 0 & 57 \text { iron rust } & 48 & \text { COD }: 1.4, \text { PO. }: .04 \text { GM } \\ -- & -- & -- & 14 & 0 & -- & 66 & 80 & 21 & \ldots & \text { GM } \\ & & & & & & & & & & \\ - & 0.0 & 9 & 34 & 0 & -- & 24 & 20 & 56 & -. & \text { BGB }\end{array}$


TABLE 5.--Chemical analyses of water from the Potomac Formation in New Castle County-Continued

\begin{tabular}{|c|c|c|c|c|c|c|c|c|c|c|c|}
\hline We 11 & $\begin{array}{l}\text { Date } \\
\text { sam- } \\
\text { pled }\end{array}$ & $\mathrm{PH}$ & $\begin{array}{l}\text { Spe- } \\
\text { cific } \\
\text { con- } \\
\text { duc- } \\
\text { tance }\end{array}$ & $\begin{array}{l}\text { Total } \\
\text { dis- } \\
\text { solved } \\
\text { solids }\end{array}$ & $\begin{array}{l}\text { Iron } \\
\text { (Fe) }\end{array}$ & $\begin{array}{l}\text { Man- } \\
\text { ga- } \\
\text { nese } \\
(\mathrm{Mn})\end{array}$ & $\begin{array}{l}\text { Sodi- } \\
\text { um } \\
(\mathrm{Na})\end{array}$ & $\begin{array}{l}\text { Chlo- } \\
\text { ride } \\
\text { (C1) }\end{array}$ & $\begin{array}{l}\text { Flo- } \\
\text { ride } \\
\text { (F) }\end{array}$ & $\begin{array}{l}\mathrm{Cal-} \\
\text { cium } \\
\text { (Ca) }\end{array}$ & $\begin{array}{l}\text { Mag- } \\
\text { ne- } \\
\text { sium } \\
(\mathrm{Mg})\end{array}$ \\
\hline
\end{tabular}

\section{Middletown}

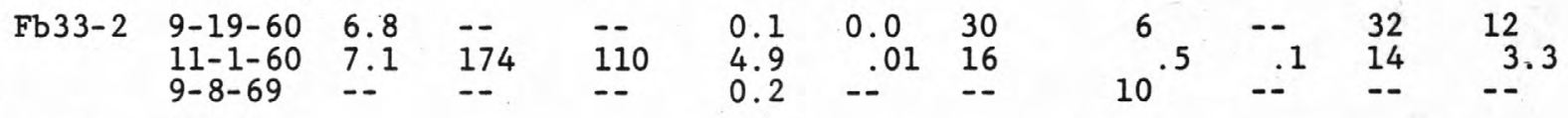

Newark

\begin{tabular}{|c|c|c|c|c|c|c|c|c|c|c|c|}
\hline Ca55-3 & $4-26-51$ & 6.5 & 111 & -- & -- & -- & -- & 12 & -- & -- & -- \\
\hline Ca55-5 & $\begin{array}{l}4-26-51 \\
12-18-51 \\
10-1-66\end{array}$ & $\begin{array}{l}6.0 \\
5.6 \\
6.8\end{array}$ & $\begin{array}{l}144 \\
142 \\
--\end{array}$ & $\begin{array}{r}-- \\
88 \\
120\end{array}$ & $\begin{array}{l}-- \\
0 \\
0\end{array}$ & $\begin{array}{l}-- \\
\overline{0}\end{array}$ & $--\overline{9} .7$ & $\begin{array}{r}16 \\
16 \\
0\end{array}$ & $0^{.1}$ & 10.0 & $\begin{array}{r}- \\
5.1 \\
6.8\end{array}$ \\
\hline Ca55-7 & $9-22-53$ & 5.6 & 83.2 & -- & .03 & -- & -- & 9 & -- & -- & -- \\
\hline $\mathrm{Cb} 51-2$ & $4-26-51$ & 5.8 & 113 & -- & -- & -- & -- & 12 & -- & -- & -- \\
\hline $\mathrm{Db} 11-49$ & $10-13-66$ & 6.8 & -- & 60 & 0.1 & 0 & - & 2 & 0 & 3.2 & 7.3 \\
\hline $\mathrm{Db} 12-41$ & $2-13-70$ & 5.7 & -- & -- & 0.72 & 0.02 & -- & 4 & -- & -- & -- \\
\hline $\mathrm{Db} 22-42$ & $8-19-68$ & 5.7 & -- & -- & 0.42 & 0 & -- & 4 & -- & -- & -- \\
\hline $\mathrm{Db} 22-49$ & $5-23-68$ & 6.4 & -- & -- & 0.63 & 0 & -- & 6 & -- & -- & -- \\
\hline $\mathrm{Db} 31-50$ & $5-26-29$ & 6.5 & -- & -- & 0.37 & 0 & -- & 6 & -- & -- & -- \\
\hline $\mathrm{Db} 32-16$ & $\begin{array}{l}10-13-71 \\
6-13-72 \\
12-9-76\end{array}$ & $\begin{array}{l}6.0 \\
6.2 \\
6.5\end{array}$ & -- & $\begin{array}{c}188 \\
38.3 \\
--\end{array}$ & $\begin{array}{l}3.85 \\
5.5 \\
3.6\end{array}$ & $\begin{array}{l}0.08 \\
0.10 \\
0.14\end{array}$ & $\begin{array}{r}-- \\
3.5 \\
4.0\end{array}$ & $\begin{array}{l}4 \\
2.0 \\
5.79\end{array}$ & $\begin{array}{r}-- \\
<0.1 \\
0.1\end{array}$ & $\begin{array}{l}-- \\
\overline{79} .5\end{array}$ & $\begin{array}{l}-- \\
\overline{7} 9.5\end{array}$ \\
\hline
\end{tabular}

New Castle

\begin{tabular}{|c|c|c|c|c|c|c|c|c|c|c|}
\hline $\operatorname{Cc55-17}$ & $9-4-69$ & 6.1 & -- & -- & 0.04 & 0.01 & -- & 8 & -- & -- \\
\hline $\operatorname{Cc} 55-18$ & $\begin{array}{l}7-17-68 \\
7-18-68\end{array}$ & $\begin{array}{l}5.9 \\
5.7\end{array}$ & -- & $\begin{array}{c}56 \\
--\end{array}$ & $\begin{array}{l}0.15 \\
0.04\end{array}$ & $\begin{array}{l}0.00 \\
0.00\end{array}$ & -- & $\begin{array}{l}9 \\
7\end{array}$ & -- & -- \\
\hline Cd52-13 & $10-28-55$ & 6.0 & 46.7 & 33 & 2.1 & -- & 3.0 & 2.4 & -- & 3.9 \\
\hline
\end{tabular}

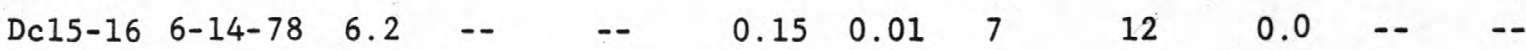

Newport

$\begin{array}{lllllllllll}\text { Cc34-8 } & 9-20-55 & 7.0 & 134 & 89 & .12 & -- & 11 & 13 & .1 & \ldots\end{array}$

Ommelanden

Park

$\begin{array}{lllllllllll}\text { Dc33-5 } & 5-28-76 & 6.1 & - & -- & 0.05 & 0.0 & - & 9 & 0.0 & -. \\ \text { Dc33-6 } & 5-26-76 & 6.0 & -- & -- & 0.15 & 0.0 & - & 4 & 0.0 & - \\ \text { Dc34-9 } & 5-18-76 & 5.8 & -- & -- & 0.01 & 0.0 & -- & 1 & 0.0 & --\end{array}$

7 as $\mathrm{CaCO}_{3}$. 


\begin{tabular}{|c|c|c|c|c|c|c|c|c|c|c|}
\hline $\begin{array}{l}\text { Silica } \\
\left(\mathrm{SiO}_{2}\right)\end{array}$ & $\begin{array}{l}\text { Ni- } \\
\text { trate } \\
\text { Ni- } \\
\text { trogen } \\
\left(\mathrm{NO}_{3}-\mathrm{N}\right)\end{array}$ & $\begin{array}{l}\text { Sul- } \\
\text { fate } \\
\left(\mathrm{SO}_{4}\right)\end{array}$ & $\begin{array}{l}\text { Total } \\
\text { hard- } \\
\text { ness } \\
\text { as } \\
\mathrm{CaCO}_{3}\end{array}$ & $\begin{array}{l}\text { Non- } \\
\text { car- } \\
\text { bon- } \\
\text { ate } \\
\text { hard- } \\
\text { ness }\end{array}$ & $\begin{array}{l}\text { Bi- } \\
\text { car- } \\
\text { bon- } \\
\text { ate } \\
\left(\mathrm{HCO}_{3}\right)\end{array}$ & $\begin{array}{l}\text { Free } \\
\text { car- } \\
\text { bonic } \\
\text { acid } \\
\left(\mathrm{CO}_{2}\right)\end{array}$ & $\begin{array}{l}\text { Tur- } \\
\text { bid- } \\
\text { ity }\end{array}$ & $\begin{array}{l}\text { Alka- } \\
\text { lin- } \\
\text { ity }\end{array}$ & Other & Source \\
\hline $\begin{array}{l}10.8 \\
9.8 \\
--\end{array}$ & $\begin{array}{l}-- \\
0.20 \\
--\end{array}$ & $\begin{array}{l}10 \\
9.0 \\
25\end{array}$ & $\begin{array}{l}44 \\
49 \\
90\end{array}$ & $\begin{array}{l}-- \\
--\end{array}$ & $\begin{array}{l}\overline{-} \\
\overline{102}\end{array}$ & $\begin{array}{l}17 \\
-- \\
5\end{array}$ & $\begin{array}{r}25 \\
-2\end{array}$ & $\begin{array}{r}60 \\
100\end{array}$ & $\mathrm{k}:-\overline{6} .3$ & $\begin{array}{l}\text { DNREC } \\
\text { DGS } \\
\text { DGS }\end{array}$ \\
\hline-- & 2.94 & 7.8 & 31 & 20 & 14 & -- & -- & -- & -- & $G, M$ \\
\hline 11 & $\begin{array}{l}4.52 \\
5.42 \\
--\end{array}$ & $\begin{array}{r}10 \\
9 \\
7\end{array}$ & $\begin{array}{l}34 \\
36 \\
54\end{array}$ & $\begin{array}{l}23 \\
-- \\
--\end{array}$ & $\begin{array}{l}13 \\
10 \\
--\end{array}$ & $\overline{10}$ & $-\overline{0}$ & $\overline{--}$ & $\begin{array}{l}\text { Other Metals } \\
\mathrm{K}: 1.8 \\
\mathrm{PO}_{4}: 0, \mathrm{Cu}: 0\end{array}$ & $\begin{array}{l}G, R \\
G, R, M \\
G M\end{array}$ \\
\hline-- & 1.76 & 1 & 16 & 8 & 10 & -- & -- & -- & $K: 5.6$ & $G, R, M$ \\
\hline-- & 4.52 & 5.9 & 32 & 24 & 10 & -- & -- & -- & -- & $G, M$ \\
\hline 0 & -- & 0 & 38 & -- & -- & 5.0 & 0 & 16 & $\mathrm{PO}_{4}: 1.5, \mathrm{Cu}: 0$ & GM \\
\hline-- & 0.25 & 12 & 8 & 1 & 27 & 18 & -- & 7 & -- & BGB \\
\hline-- & 0.36 & 11.2 & 6 & 0 & -- & 21 & 10 & 6 & -- & $\mathrm{BGB}$ \\
\hline-- & 0.32 & 14.8 & 12 & 7 & -- & 9 & 50 & 5 & -- & BGB \\
\hline-- & 2.71 & 8 & 44 & 7 & -- & 20 & 40 & 37 & -- & $\mathrm{BGB}$ \\
\hline $\begin{array}{l}-- \\
--\end{array}$ & $\begin{array}{r}0.00 \\
<0.02 \\
0.25\end{array}$ & $\begin{array}{l}11 \\
20.6\end{array}$ & $\begin{array}{l}16 \\
18.4 \\
20\end{array}$ & $\begin{array}{l}8 \\
0.5 \\
19\end{array}$ & $\begin{array}{l}-- \\
-- \\
--\end{array}$ & $\begin{array}{l}30 \text { iron } \\
43.0 \\
--\end{array}$ & $\begin{array}{l}\text { rust } \\
23 \\
42\end{array}$ & $\begin{array}{l}8 \\
17 \\
14\end{array}$ & $\begin{array}{l}-- \\
--\end{array}$ & $\begin{array}{l}\text { BGB } \\
\text { BA } \\
\text { BA }\end{array}$ \\
\hline-- & 1.35 & 1 & 14 & 4 & -- & 23 & 3 & 10 & -- & $\mathrm{BGB}$ \\
\hline-- & $\begin{array}{l}2.89 \\
1.72\end{array}$ & $\begin{array}{l}2.5 \\
2.5\end{array}$ & $\begin{array}{l}14 \\
14\end{array}$ & $\begin{array}{l}5 \\
5\end{array}$ & -- & $\begin{array}{l}28 \\
26\end{array}$ & $\begin{array}{l}0 \\
0\end{array}$ & $\begin{array}{l}9 \\
9\end{array}$ & $\begin{array}{l}-- \\
--\end{array}$ & $\begin{array}{l}\text { BGB } \\
\text { BGB }\end{array}$ \\
\hline 9.4 & .41 & .6 & 16 & 1 & 19 & -- & -- & -- & Other Metals & $\mathbf{R}$ \\
\hline-- & 1.0 & 5 & 22 & 7 & -- & 31 & 0.3 & 15 & -- & BGB \\
\hline 8.8 & 4.74 & 9.9 & 35 & 23 & 15 & -- & -- & -- & -- & $\mathrm{R}$ \\
\hline-- & 1.08 & 7 & 24 & 9 & -- & 40 & 3.3 & 15 & -- & BGB \\
\hline-- & 1.35 & 10 & 14 & 4 & -- & 35 & 0.8 & 10 & -- & BGB \\
\hline-- & 1.81 & 3.0 & 10 & 2 & -- & 37 & -- & 8 & -- & BGB \\
\hline
\end{tabular}


TABLE 5.--Chemical analyses of water from the Potomac Formation in New Castle County-Continued

\begin{tabular}{|c|c|c|c|c|c|c|c|c|c|c|c|}
\hline Well & $\begin{array}{l}\text { Date } \\
\text { sam- } \\
\text { pled }\end{array}$ & $\mathrm{PH}$ & $\begin{array}{l}\text { Spe- } \\
\text { cific } \\
\text { con- } \\
\text { duc- } \\
\text { tance }\end{array}$ & $\begin{array}{l}\text { Total } \\
\text { dis- } \\
\text { solved } \\
\text { solids }\end{array}$ & $\begin{array}{l}\text { Iron } \\
\text { (Fe) }\end{array}$ & $\begin{array}{l}\text { Man- } \\
\text { ga- } \\
\text { nese } \\
(\mathrm{Mn})\end{array}$ & $\begin{array}{l}\text { Sodi- } \\
\text { um } \\
\text { (Na) }\end{array}$ & $\begin{array}{l}\text { Chlo- } \\
\text { ride } \\
\text { (CI) }\end{array}$ & $\begin{array}{l}\text { Flo- } \\
\text { ride } \\
\text { (F) }\end{array}$ & $\begin{array}{l}\text { Cal- } \\
\text { cium } \\
\text { (Ca) }\end{array}$ & $\begin{array}{l}\text { Mag- } \\
\text { ne- } \\
\text { sium } \\
(\mathrm{Mg})\end{array}$ \\
\hline
\end{tabular}

Union

Carbide

\begin{tabular}{|c|c|c|c|c|c|c|c|c|c|c|}
\hline Ec $32-5$ & $10-14-66$ & 6.8 & -- & 96 & 5.8 & 0.05 & -- & 1 & -- & -- \\
\hline Ec32-7 & $\begin{array}{l}8-19-66 \\
8-30-66\end{array}$ & $\begin{array}{r}7.0 \\
-.-\end{array}$ & -- & 116 & 1.90 & 0.02 & -- & $\begin{array}{l}12 \\
10\end{array}$ & -- & -- \\
\hline
\end{tabular}

Wilmington

Airport

\begin{tabular}{|c|c|c|c|c|c|c|c|c|c|c|}
\hline Cc45-1 & $\begin{array}{l}9-3-57 \\
1-31-75\end{array}$ & $\overline{7.0}$ & $13 \overline{8}$ & $\overline{80}$ & $-\overline{4.25}$ & -- & -- & $\begin{array}{l}5.3 \\
2.3\end{array}$ & $\overline{0.06}$ & -- \\
\hline Cc55-1 & $\begin{array}{l}9-20-55 \\
4-3-57 \\
9-3-57\end{array}$ & $\begin{array}{l}-- \\
-- \\
--\end{array}$ & $\begin{array}{l}-- \\
-- \\
--\end{array}$ & $\begin{array}{l}-- \\
--\end{array}$ & $\begin{array}{l}2.3 \\
-- \\
--\end{array}$ & $\begin{array}{l}-- \\
-- \\
--\end{array}$ & $\begin{array}{l}-- \\
-- \\
--\end{array}$ & $\begin{array}{r}-\overline{2} .5 \\
5.0\end{array}$ & $\begin{array}{l}-- \\
-- \\
--\end{array}$ & $\begin{array}{l}-- \\
--\end{array}$ \\
\hline
\end{tabular}

\section{Miscellaneous}

\begin{tabular}{|c|c|c|c|c|c|c|c|c|c|c|c|}
\hline Cc45-5 & $5-24-74$ & 7.0 & 141.0 & -- & 4.15 & -- & -- & 3.9 & -- & -- & -- \\
\hline Cd15-1 & $\begin{array}{lr}7- & -53 \\
6- & -53 \\
6-28 & -55\end{array}$ & $\begin{array}{l}7.2 \\
7.6\end{array}$ & $\begin{array}{r}-- \\
659\end{array}$ & $\begin{array}{l}-- \\
-- \\
--\end{array}$ & $\begin{array}{l}11 \\
-- \\
--\end{array}$ & $\begin{array}{l}-- \\
-- \\
--\end{array}$ & -- & $\begin{array}{r}16 \\
3.5 \\
3.5\end{array}$ & $\begin{array}{l}-- \\
-- \\
--\end{array}$ & $\begin{array}{r}139 \\
-- \\
--\end{array}$ & $\begin{array}{l}11 \\
-- \\
--\end{array}$ \\
\hline Cd33-2 & $\begin{array}{l}7-22-56 \\
1-18-54 \\
6-28-55 \\
4-18-57\end{array}$ & $\begin{array}{l}6.4 \\
-- \\
5.4 \\
--\end{array}$ & 1060 & $\begin{array}{l}-- \\
-- \\
-- \\
--\end{array}$ & $\begin{array}{l}>0.5 \\
-- \\
-- \\
--\end{array}$ & $\begin{array}{l}-- \\
-- \\
-- \\
--\end{array}$ & $13 \overline{-}$ & $\begin{array}{r}23 \\
515 \\
218 \\
174\end{array}$ & $\begin{array}{l}-- \\
-- \\
-- \\
--\end{array}$ & $\begin{array}{l}-- \\
-- \\
-- \\
--\end{array}$ & $\begin{array}{l}-- \\
-- \\
--\end{array}$ \\
\hline Ec23-9 & -68 & 6.8 & -- & -- & 10.9 & 0.08 & -- & 4 & -- & -- & -- \\
\hline
\end{tabular}




\begin{tabular}{|c|c|c|c|c|c|c|c|c|c|c|}
\hline $\begin{array}{l}\text { Silica } \\
\left(\mathrm{SiO}_{2}\right)\end{array}$ & $\begin{array}{l}\text { Ni- } \\
\text { trate } \\
\text { Ni- } \\
\text { trogen } \\
\left(\mathrm{NO}_{3-\mathrm{N}} \text { ) }\right.\end{array}$ & $\begin{array}{l}\text { Sul- } \\
\text { fate } \\
\left(\mathrm{SO}_{4}\right)\end{array}$ & $\begin{array}{l}\text { Total } \\
\text { hard- } \\
\text { ness } \\
\text { as } \\
\mathrm{CaCO}_{3}\end{array}$ & $\begin{array}{l}\text { Non- } \\
\text { car- } \\
\text { bon- } \\
\text { ate } \\
\text { hard- } \\
\text { ness }\end{array}$ & $\begin{array}{l}\text { Bi- } \\
\text { car- } \\
\text { bon- } \\
\text { ate } \\
\left(\mathrm{HCO}_{3}\right)\end{array}$ & $\begin{array}{l}\text { Free } \\
\text { car- } \\
\text { bonic } \\
\text { acid } \\
\left(\mathrm{CO}_{2}\right)\end{array}$ & $\begin{array}{l}\text { Tur- } \\
\text { bid- } \\
\text { ity }\end{array}$ & $\begin{array}{l}\text { Alka- } \\
\text { lin- } \\
\text { ity }\end{array}$ & Other & Source \\
\hline-- & -- & -- & 40 & 0 & -- & 24 & iron rust & t 59 & -- & GM \\
\hline-- & -- & $=-$ & 24 & 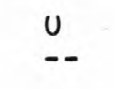 & $=$ & 13 & $\begin{array}{r}5 \\
--\end{array}$ & $\begin{array}{l}75 \\
--\end{array}$ & $=-$ & $\begin{array}{l}\mathrm{GM} \\
\mathrm{GM}\end{array}$ \\
\hline-- & $\overline{0.60}$ & $\overline{8.5}$ & $\overline{44.0}$ & $=-$ & $=$ & $\overline{20 .} 0$ & $-\overline{5.1}$ & $=-$ & Other Metals & $\begin{array}{l}\text { W } \\
\text { DNREC }\end{array}$ \\
\hline $\begin{array}{l}-- \\
--\end{array}$ & $\begin{array}{l}-- \\
-- \\
--\end{array}$ & $\begin{array}{l}-- \\
-- \\
--\end{array}$ & $\begin{array}{l}-- \\
-- \\
--\end{array}$ & $\begin{array}{l}-- \\
-- \\
--\end{array}$ & $\begin{array}{l}-- \\
-- \\
--\end{array}$ & $\begin{array}{l}-- \\
-- \\
--\end{array}$ & $\begin{array}{l}-- \\
-- \\
--\end{array}$ & $\begin{array}{l}-- \\
--\end{array}$ & $\begin{array}{c}\mathrm{Zn}: 14 \\
-- \\
--\end{array}$ & $\begin{array}{l}R \\
W \\
W\end{array}$ \\
\hline-- & -- & -- & 48.0 & -- & -- & -- & 2.3 & 70 & -- & DNREC \\
\hline $\begin{array}{l}.6 \\
-- \\
--\end{array}$ & $\begin{array}{l}-- \\
\overline{0} .14\end{array}$ & $\begin{array}{l}120 \\
141\end{array}$ & $\begin{array}{l}231 \\
245\end{array}$ & $\begin{array}{l}-- \\
90\end{array}$ & $\overline{--}$ & $\begin{array}{l}-- \\
--\end{array}$ & $\begin{array}{l}-- \\
-- \\
--\end{array}$ & $\begin{array}{l}-- \\
--\end{array}$ & $\begin{array}{l}-- \\
--\end{array}$ & $\begin{array}{l}\mathrm{M}, \mathrm{R} \\
\mathrm{W} \\
\mathrm{R}\end{array}$ \\
\hline $\begin{array}{l}-- \\
-- \\
--\end{array}$ & $\begin{array}{l}-- \\
-.05\end{array}$ & 139 & $\begin{array}{r}42 \\
-- \\
165 \\
--\end{array}$ & $\begin{array}{l}-- \\
\overline{-} \\
157 \\
--\end{array}$ & $\begin{array}{l}-- \\
\overline{10} \\
--\end{array}$ & $\begin{array}{l}-- \\
-- \\
--\end{array}$ & $\begin{array}{l}-- \\
-- \\
--\end{array}$ & $\begin{array}{l}-- \\
-- \\
-- \\
--\end{array}$ & $\begin{array}{l}-- \\
-- \\
--\end{array}$ & $\begin{array}{l}\mathrm{R} \\
\mathrm{W} \\
\mathrm{R} \\
\mathrm{W}\end{array}$ \\
\hline-- & 0.0 & 6.4 & 38 & 0 & -- & 31 & iron rust & $t 50$ & -- & BGB \\
\hline
\end{tabular}




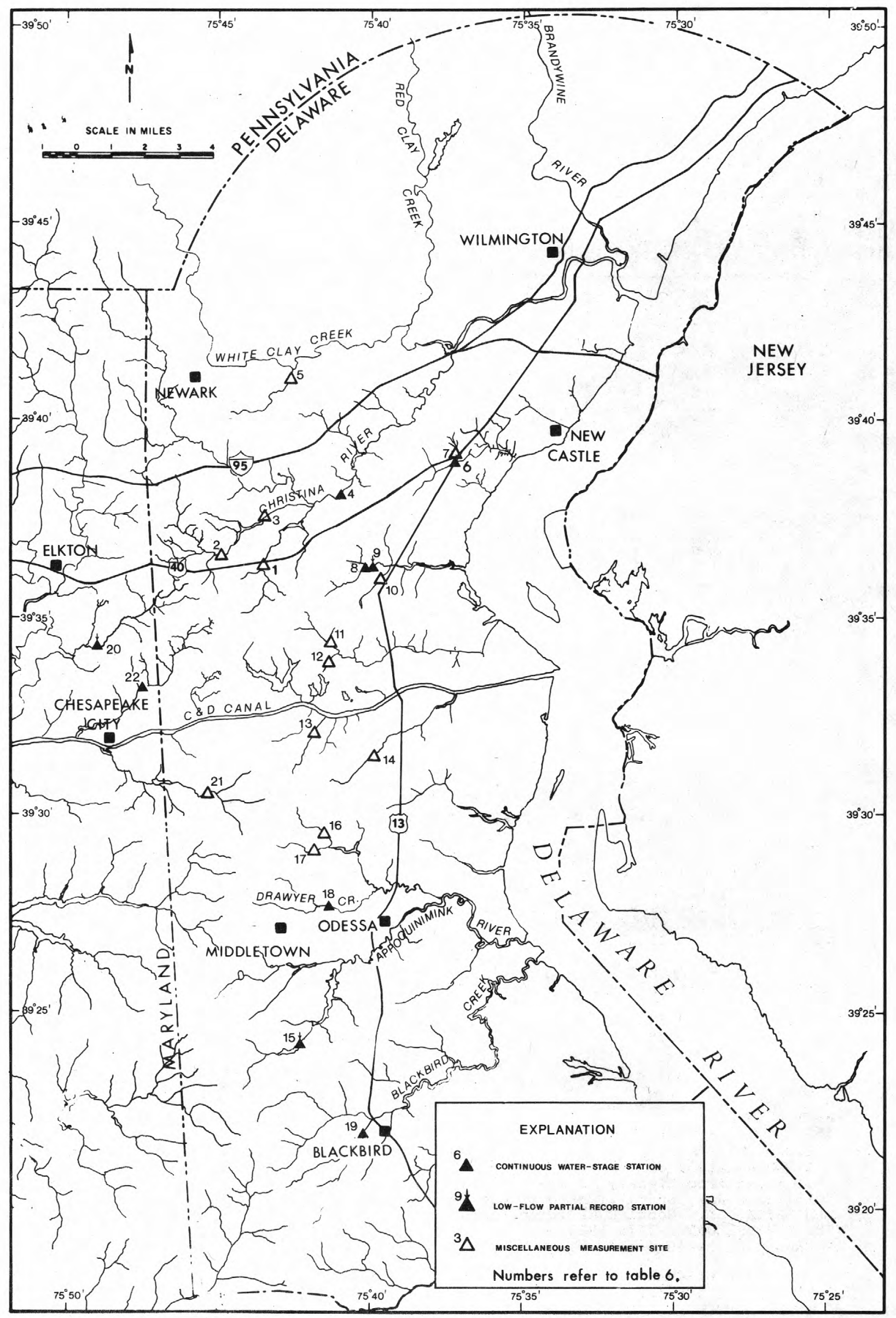

FIGURE 68.--Location of selected stream flow measuring sites. 
TABLE 6.--Low-flow discharge at selected surface-water stations in New Castle County, Del. Index numbers refer to station locations shown in Figure 69.

INDEX NUMBER. --1 .

STATION NAME.--Belltown Run near Glasgow, DE.

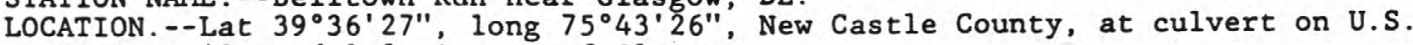
Highway 40 , and $1.2 \mathrm{mi}$ east of Glasgow.

CLASSIFICATION. --Miscellaneous measuring site.

PERIOD OF RECORD.--1978-1980.

DRAINAGE AREA. $--3.35 \mathrm{mi}^{2}$.

$\begin{array}{lccccc}\text { DATE } & \begin{array}{c}\text { DISCHARGE } \\ \left(\mathrm{ft}^{3} / \mathrm{s}\right)\end{array} & \text { DATE } & \begin{array}{c}\text { DISCHARGE } \\ \left(\mathrm{ft}^{3} / \mathrm{s}\right)\end{array} & \text { DATE } & \begin{array}{c}\text { DISCHARGE } \\ \left(\mathrm{ft}^{3} / \mathrm{s}\right)\end{array} \\ 9-7-78 & 0.84 & 5-10-79 & 1.22 & 2-13-80 & 1.40 \\ 10-12-78 & 0.44 & 11-1-79 & 2.61 & 7-17-80 & 0.71\end{array}$

INDEX NUMBER. --2 .

STATION NAME. --Muddy Run at Glasgow, DE.

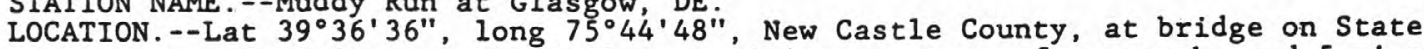

Highway $896,0.3 \mathrm{mi}$ north of Glasgow, $3.4 \mathrm{mi}$ upstream from mouth, and 5 mi south of Newark.

CLASSIFICATION.--Miscellaneous measuring site.

PERIOD OF RECORD. --1968-1970, 1978-1979.

DRAINAGE AREA. $--5.43 \mathrm{mi}^{2}$.

$\begin{array}{cccccc}\text { DATE } & \begin{array}{c}\text { DISCHARGE } \\ \left(\mathrm{ft}^{3} / \mathrm{s}\right)\end{array} & \text { DATE } & \begin{array}{c}\text { DISCHARGE } \\ \left(\mathrm{ft}^{3} / \mathrm{s}\right)\end{array} & \text { DATE } & \begin{array}{c}\text { DISCHARGE } \\ \left(\mathrm{ft}^{3} / \mathrm{s}\right)\end{array} \\ 9-10-68 & 0.32 & 9-24-69 & 0.44 & 9-7-78 & 1.10 \\ 4-15-69 & 1.62 & 6-2-70 & 1.16 & 10-12-78 & 0.55 \\ 7-3-69 & 0.28 & 9-3-70 & 0.45 & 5-10-79 & 1.91\end{array}$

INDEX NUMBER. --3 .

STATION NAME. --Muddy Run near Coochs Bridge, DE.

LOCATION. - Lat 39 $37^{\prime} 34^{\prime \prime}$, long $75^{\circ} 43^{\prime} 28^{\prime \prime}$, New Castle County, at bridge on State

Highway $72,1.9 \mathrm{mi}$ northeast of Glasgow, and $0.9 \mathrm{mi}$ southeast of Coochs Bridge. CLASSIFICATION. --Miscellaneous measuring site.

PERIOD OF RECORD. - -1978-1980.

DRAINAGE AREA. $--8.21 \mathrm{mi}^{2}$.

$\begin{array}{cccccc}\text { DATE } & \begin{array}{c}\text { DISCHARGE } \\ \left(\mathrm{ft}^{3} / \mathrm{s}\right)\end{array} & \text { DATE } & \begin{array}{c}\text { DISCHARGE } \\ \left(\mathrm{ft}^{3} / \mathrm{s}\right)\end{array} & \text { DATE } & \begin{array}{c}\text { DISCHARGE } \\ \left(\mathrm{ft}^{3} / \mathrm{s}\right)\end{array} \\ 10-12-78 & 0.73 & 2-13-80 & 2.00 & 7-17-80 & 1.06\end{array}$

INDEX NUMBER. --4 .

STATION NUMBER. --01478040.

STATION NAME.--Christina River near Bear, DE.

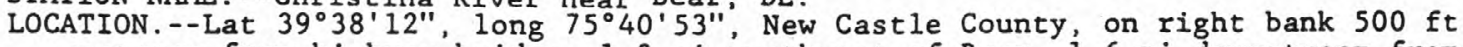
upstream from highway'bridge, $1.3 \mathrm{mi}$ northwest of Bear, $1.6 \mathrm{mi}$ downstream from Belltown Run, and $17.7 \mathrm{mi}$ upstream from mouth.

CLASSIFICATION. - - Continuous water-stage station.

PERIOD OF RECORD. --1978-1980.

DRAINAGE AREA. $--40.6 \mathrm{mi}^{2}$.

$\begin{array}{lccccc}\text { DATE } & \begin{array}{c}\text { DISCHARGE } \\ \left(\mathrm{ft}^{3} / \mathrm{s}\right)\end{array} & \text { DATE } & \begin{array}{c}\text { DISCHARGE } \\ \left(\mathrm{ft}^{3} / \mathrm{s}\right)\end{array} & \text { DATE } & \begin{array}{c}\text { DISCHARGE } \\ \left(\mathrm{ft}^{3} / \mathrm{s}\right)\end{array} \\ 9-29-78 & 7.61 & 5-10-79 & 22.50 & 2-13-80 & 14.10 \\ 10-12-78 & 6.28 & & & \end{array}$


TABLE 6.--Low-flow discharge at selected surface-water stations in New Castle County--Continued

INDEX NUMBER. --5 .

STATION NAME. - White Clay Creek Tributary near Ogletown, DE.

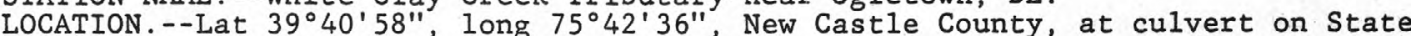

Highway 273, $100 \mathrm{ft}$ east of Penn Central Railroad and 0.7 mi northwest of Ogletown.

CLASSIFICATION. --Miscellaneous measuring site.

PERIOD OF RECORD. - -1978-1980.

DRAINAGE AREA. $--3.68 \mathrm{mi}^{2}$.

$\begin{array}{lccccc}\text { DATE } & \begin{array}{c}\text { DISCHARGE } \\ \left(\mathrm{ft}^{3} / \mathrm{s}\right)\end{array} & \text { DATE } & \begin{array}{c}\text { DISCHARGE } \\ \left(\mathrm{ft}^{3} / \mathrm{s}\right)\end{array} & \text { DATE } & \begin{array}{c}\text { DISCHARGE } \\ \left(\mathrm{ft}^{3} / \mathrm{s}\right)\end{array} \\ 9-7-78 & 0.67 & 5-10-79 & 1.01 & 7-17-80 & 0.79 \\ 10-12-78 & 0.95 & 2-13-80 & 0.80 & & \end{array}$

INDEX NUMBER. --6 .

STATION NUMBER. - 01482200.

STATION NAME.--Army Creek at State Road, DE.

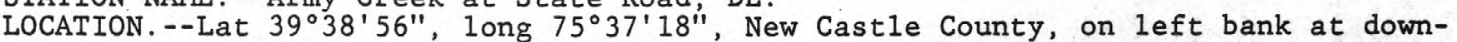
stream end of culvert on U.S. Highway 13, $0.2 \mathrm{mi}$ south of State Road, and $2.3 \mathrm{mi}$ upstream from mouth.

CLASSIFICATION.--Continuous water-stage station.

PERIOD OF RECORD. - -1978-1980.

DRAINAGE AREA. $--2.42 \mathrm{mi}^{2}$.

$\begin{array}{cccccc}\text { DATE } & \begin{array}{c}\text { DISCHARGE } \\ \left(\mathrm{ft}^{3} / \mathrm{s}\right)\end{array} & \text { DATE } & \begin{array}{c}\text { DISCHARGE } \\ \left(\mathrm{ft}^{3} / \mathrm{s}\right)\end{array} & \text { DATE } & \begin{array}{c}\text { DISCHARGE } \\ \left(\mathrm{ft}^{3} / \mathrm{s}\right)\end{array} \\ 7-21-78 & 0.08 & 9-12-78 & 0.09 & 2-13-80 & 0.19 \\ 9-7-78 & 0.10 & 5-10-79 & 0.49 & 7-17-80 & 0.13 \\ 9-11-78 & 0.10 & 11-1-79 & 0.18 & & \end{array}$

INDEX NUMBER. --7 .

STATION NAME.--Army Creek Tributary at State Road, DE.

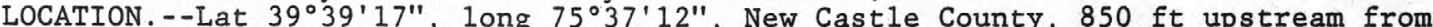

U.S. Highway 40, at State Road, and $2700 \mathrm{ft}$ upstream from mouth. Prior to

July 1980 , site was $1900^{\circ} \mathrm{ft}$ upstream from mouth at lat $39^{\circ} 39^{\prime} 12^{\prime \prime}$ and long

CLASSIFICATION.--Miscellaneous measuring site.

PERIOD OF RECORD, --1978-1980.

DRAINAGE AREA. $-0.32 \mathrm{mi}^{2}$. Prior to July 1980 drainage area was $0.38 \mathrm{mi}^{2}$.

$\begin{array}{cccccc}\text { DATE } & \begin{array}{c}\text { DISCHARGE } \\ \left(\mathrm{ft}^{3} / \mathrm{s}\right)\end{array} & \text { DATE } & \begin{array}{c}\text { DISCHARGE } \\ \left(\mathrm{ft}^{3} / \mathrm{s}\right)\end{array} & \text { DATE } & \begin{array}{c}\text { DISCHARGE } \\ \left(\mathrm{ft}^{3} / \mathrm{s}\right)\end{array} \\ 10-5-78 & 0.05 & 11-1-79 & 0.05 & 7-17-80 & 0.02\end{array}$

INDEX NUMBER. --8 .

STATION NUMBER. - 01482298.

STATION NAME. - Red Lion Crcek near Red Lion, DE.

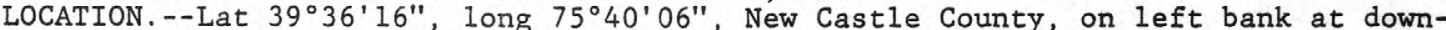
stream side of culvert on U.S. Highway 301S, $0.2 \mathrm{mi}$ southwest of Red Lion, and $3.4 \mathrm{mi}$ upstream from mouth.

CLASSIFICATION.--Continuous water-stage station.

PERIOD OF RECORD. --1978-1980.

DRATNAGE AREA. $--3.08 \mathrm{mi}^{2}$.

$\begin{array}{cccccc}\text { DATE } & \begin{array}{c}\text { DISCHARGE } \\ \left(\mathrm{ft}^{3} / \mathrm{s}\right)\end{array} & \text { DATE } & \begin{array}{c}\text { DISCHARGE } \\ \left(\mathrm{ft}^{3} / \mathrm{s}\right)\end{array} & \text { DATE } & \begin{array}{c}\text { DISCHARGE } \\ \left(\mathrm{ft}^{3} / \mathrm{s}\right)\end{array} \\ 10-12-78 & 0.41 & 11-1-79 & 1.98 & 7-17-80 & 0.55 \\ 5-10-79 & 1.56 & 2-13-80 & 1.74 & & \end{array}$


TABLE 6.--Low-flow discharge at selected surface-water stations in New Castle County--Continued

INDEX NUMBER. --9 .

STATION NUMBER. - -01482300.

STATION NAME.--Red Lion Creek at Red Lion, DE.

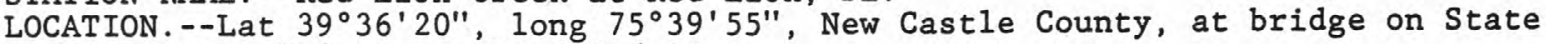
Highway $7,0.2 \mathrm{mi}$ south of Red Lion.

CLASSIFICATION. --Low-flow partial record station.

PERIOD OF RECORD. --1955-1960, 1962-1971.

DRAINAGE AREA. $--3.20 \mathrm{mi}^{2}$.

$\begin{array}{lccccc}\text { DATE } & \begin{array}{c}\text { DISCHARGE } \\ (\mathrm{ft} / \mathrm{s})\end{array} & \text { DATE } & \begin{array}{c}\text { DISCHARGE } \\ (\mathrm{ft} / \mathrm{s})\end{array} & \text { DATE } & \begin{array}{c}\text { DISCHARGE } \\ (\mathrm{ft} / \mathrm{s})\end{array} \\ 6-28-55 & 0.96 & 6-1-59 & 0.76 & 9-13-66 & 0.03 \\ 10-6-55 & 1.40 & 6-9-60 & 0.96 & 5-2-67 & 1.89 \\ 11-17-55 & 0.90 & 9-24-62 & 0.28 & 7-25-68 & 0.41 \\ 6-14-56 & 0.44 & 5-6-63 & 1.02 & 9-10-68 & 0.33 \\ 8-13-56 & 0.58 & 7-17-63 & 0.25 & 4-15-69 & 0.97 \\ 11-27-56 & 5.92 & 8-27-64 & 0.05 e & 9-26-69 & 0.17 \\ 4-16-57 & 2.34 & 9-1-65 & 0.006 & 6-2-70 & 0.67 \\ 7-3-57 & 0.43 & 10-5-65 & 0.11 & 9-3-70 & 0.26 \\ 4-21-58 & 2.80 & 7-21-66 & 0.08 & 4-27-71 & 1.13 \\ 3-3-59 & 2.09 & & & & \end{array}$

INDEX NUMBER. - - 10 .

STATION NAME.--Dol1 Run at Red Lion, DE.

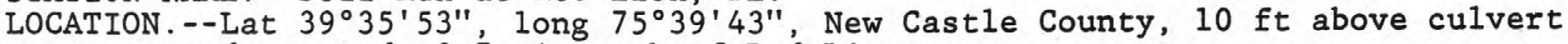
on secondary road, $0.7 \mathrm{mi}$ south of Red Lion.

CLASSIFICATION. --Miscellaneous measuring site.

PERIOD OF RECORD. --1967-1969, 1974-1979.

DRAINAGE AREA.--1.2 $\mathrm{mi}^{2}$.

\begin{tabular}{|c|c|c|c|c|c|}
\hline DATE & $\begin{array}{c}\text { DISCHARGE } \\
\left(\mathrm{ft}^{3} / \mathrm{s}\right)\end{array}$ & DATE & $\begin{array}{c}\text { DISCHARGE } \\
\left(\mathrm{ft}^{3} / \mathrm{s}\right)\end{array}$ & DATE & $\begin{array}{l}\text { DISCHARGE } \\
\left(\mathrm{ft}^{3} / \mathrm{s}\right)\end{array}$ \\
\hline $\begin{array}{l}12-4-67 \\
5-31-68 \\
4-28-69 \\
4-17-74 \\
7-26-74\end{array}$ & $\begin{array}{l}0.86 \\
1.92 \\
0.41 \\
1.26 \\
0.60\end{array}$ & $\begin{array}{l}3-18-75 \\
4-15-76 \\
9-7-76 \\
3-1-77\end{array}$ & $\begin{array}{l}0.79 \\
0.84 \\
0.38 \\
0.68\end{array}$ & $\begin{array}{l}9-6-77 \\
3-30-78 \\
9-11-78 \\
4-2-79\end{array}$ & $\begin{array}{l}0.49 \\
1.38 \\
1.07 \\
1.29\end{array}$ \\
\hline
\end{tabular}

INDEX NUMBER. --11 .

STATION NAME.--Dragon Creek at Kirkwood, DE.

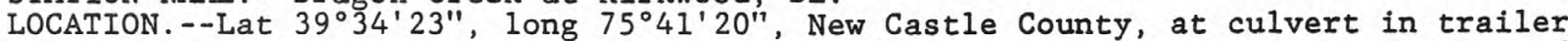
park $1500 \mathrm{ft}$ downstream from U.S. Highway $301 \mathrm{~S}, 6.8 \mathrm{mi}$ upstream from mouth, and $0.5 \mathrm{mi}$ northeast of Kirkwood.

CLASSIFICATION.--Miscellaneous measuring site.

PERIOD OF RECORD.--1978-1980.

DRAINAGE AREA. $--1.93 \mathrm{mi}^{2}$.

\begin{tabular}{|c|c|c|c|c|c|}
\hline DATE & $\begin{array}{c}\text { DISCHARGE } \\
\left(\mathrm{ft}^{3} / \mathrm{s}\right)\end{array}$ & DATE & $\begin{array}{l}\text { DISCHARGE } \\
\left(\mathrm{ft}^{3} / \mathrm{s}\right)\end{array}$ & DATE & $\begin{array}{l}\text { DISCHARGE } \\
\left(\mathrm{ft} \mathrm{t}^{3} / \mathrm{s}\right)\end{array}$ \\
\hline $\begin{array}{l}9-8-78 \\
10-12-78\end{array}$ & $\begin{array}{l}0.21 \\
0.15\end{array}$ & $\begin{array}{l}5-10-79 \\
11-1-79\end{array}$ & $\begin{array}{l}0.85 \\
1.21\end{array}$ & $\begin{array}{l}2-13-80 \\
7-17-80\end{array}$ & $\begin{array}{l}0.94 \\
0.27\end{array}$ \\
\hline
\end{tabular}

e estimated. 
TABLE 6:--Low-flow discharge at selected surface-water stations in New Castle County--Continued

INDEX NUMBER. - - 12

STATION NAME.--Dragon Creek Tributary at Kirkwood, DE.

LOCATION. - Lat $39^{\circ} 33^{\prime} 52^{\prime \prime}$, long $75^{\circ} 41^{\prime} 16^{\prime \prime}$, New Castle County, at culvert on Road No. $409,0.4 \mathrm{mi}$ upstream from mouth, and $0.7 \mathrm{mi}$ east of Kirkwood.

CLASSIFICATION. --Miscellaneous measuring site.

PERIOD OF RECORD. --1978-1980.

DRAINAGE AREA. $--0.16 \mathrm{mi}^{2}$.

$\begin{array}{lcccc}\text { DATE } & \begin{array}{c}\text { DISCHARGE } \\ \left(\mathrm{ft}^{3} / \mathrm{s}\right)\end{array} & \text { DATE } & \begin{array}{c}\text { DISCHARGE } \\ \left(\mathrm{ft}^{3} / \mathrm{s}\right)\end{array} & \begin{array}{c}\text { DISCHARGE } \\ \left(\mathrm{ft}^{3} / \mathrm{s}\right)\end{array} \\ 9-8-78 & 0.07 & 5-10-79 & 0.17 & 0.12 \\ 10-12-78 & 0.03 & 11-1-79 & 0.18 & 7-17-80\end{array}$

INDEX NUMBER, --13

STATION NAME.--Joy Run near Summit Bridge, DE.

LOCATION. - Lat $39^{\circ} 32^{\prime} 02^{\prime \prime}$, long $75^{\circ} 41^{\prime} 48^{\prime \prime}$, New Castle County, at culvert on Road

No. $412,0.6 \mathrm{mi}$ upstream from mouth at Chesapeake and Delaware Canal, and 1.6 mi east of Summit Bridge.

CLASSIFICATION.--Miscellaneous measuring site.

PERIOD OF RECORD. - -1978-1980.

DRAINAGE AREA. $--1.26 \mathrm{mi}^{2}$.

\begin{tabular}{|c|c|c|c|c|c|}
\hline DATE & $\begin{array}{l}\text { DISCHARGE } \\
\left(\mathrm{ft}^{3} / \mathrm{s}\right)\end{array}$ & DATE & $\begin{array}{l}\text { DISCHARGE } \\
\left(\mathrm{ft}^{3} / \mathrm{s}\right)\end{array}$ & DATE & $\begin{array}{c}\text { DISCHARGE } \\
\left(\mathrm{ft}^{3} / \mathrm{s}\right)\end{array}$ \\
\hline
\end{tabular}

$\begin{array}{llllll}10-15-78 & 1.48 & 2-13-80 & 1.87 & 7-17-80 & 1.68 \\ 5-10-79 & 1.77 & & \end{array}$

INDEX NUMBER. --14 .

STATION NAME.--Scott Run near Boyds Corner, DE.

LOCATION. - Lat 39 $31^{\prime} 30^{\prime \prime}$, long $75^{\circ} 39^{\prime} 54^{\prime \prime}$, New Castle County, at culvert on Road

No. $413,3.7 \mathrm{mi}$ upstream from mouth at Chesapeake and Delaware Canal, and 1.9 mi northwest of Boyds Corner.

CLASSIFICATION.--Miscellaneous measuring site.

PERIOD OF RECORD.--1978-1980.

DRAINAGE AREA. $--2.18 \mathrm{mi}^{2}$.

$\begin{array}{ccccc}\text { DATE } & \begin{array}{c}\text { DISCHARGE } \\ \left(\mathrm{ft}^{3} / \mathrm{s}\right)\end{array} & \text { DATE } & \begin{array}{c}\text { DISCHARGE } \\ \left(\mathrm{ft}^{3} / \mathrm{s}\right)\end{array} & \begin{array}{c}\text { DISCHARGE } \\ \left(\mathrm{ft}^{3} / \mathrm{s}^{2}\right)\end{array} \\ 10-5-78 & 0.60 & 11-1-79 & 1.00 & 1.06 \\ 5-10-79 & 1.25 & 2-13-80 & 0.93 & 7-17-80\end{array}$

INDEX NUMBER. --15 .

STATION NUMBER. -01483150.

STATION NAME.--Wiggins Millpond Outlet at Townsend, DE.

LOCATION. - Lat 39 $29^{\prime} 12^{\prime \prime}$, long $75^{\circ} 42^{\prime} 16^{\prime \prime}$, New Castle County, at bridge on State

Highway $446,0.8 \mathrm{mi}$ northwest of Townsend.

CLASSIFICATION. --Low-flow partial-record station.

PERIOD OF RECORD. - - 1957-1960, 1962-1966, 1968-1971, 1978-1980.

DRAINAGE AREA. $--3.82 \mathrm{mi}^{2}$.

\begin{tabular}{|c|c|c|c|c|c|}
\hline DATE & $\begin{array}{c}\text { DISCHARGE } \\
\left(\mathrm{ft}^{3} / \mathrm{s}\right)\end{array}$ & DATE & $\begin{array}{l}\text { DISCHARGE } \\
\left(\mathrm{ft}^{3} / \mathrm{s}\right)\end{array}$ & DATE & $\begin{array}{c}\text { DISCHARGE } \\
\left(\mathrm{ft}^{3} / \mathrm{s}\right)\end{array}$ \\
\hline $\begin{array}{l}4-16-57 \\
7-3-57 \\
4-21-58 \\
3-3-59 \\
6-1-59 \\
6-9-60 \\
9-24-62 \\
4-12-63\end{array}$ & $\begin{array}{l}3.86 \\
0.89 \\
7.90 \\
4.75 \\
3.20 \\
3.10 \\
2.85 \\
3.65\end{array}$ & $\begin{array}{l}5-6-63 \\
7-17-63 \\
8-27-64 \\
8-9-65 \\
10-5-65 \\
7-21-66 \\
7-25-68 \\
9-9-68\end{array}$ & $\begin{array}{l}3.25 \\
2.13 \\
2.38 \\
1.43 \\
1.49 \\
0.31 \\
1.77 \\
1.65\end{array}$ & $\begin{array}{l}4-15-69 \\
9-18-69 \\
6-2-70 \\
4-26-71 \\
9-11-78 \\
5-10-79 \\
2-13-80\end{array}$ & $\begin{array}{l}2.41 \\
1.58 \\
2.79 \\
2.68 \\
2.26 \\
4.02 \\
4.19\end{array}$ \\
\hline
\end{tabular}


TABLE 6.--Low-flow discharge at selected surface-water stations in New Castle County--Continued

INDEX NUMBER. - - 16 .

STATION NAME.--Drawyer Creek near Mt. Pleasant, DE

LOCATION. --Lat 39 $29^{\prime} 34^{\prime \prime}$, long $75^{\circ} 41^{\prime} 24^{\prime \prime}$, New Castle County, at culvert on Road No. $427,0.5 \mathrm{mi}$ upstream from Shallcross Lake, and $1.7 \mathrm{mi}$ southeast of Mt. Pleasant.

CLASSIFICATION. - Miscellaneous measuring site.

PERIOD OF RECORD - - 1978-1980.

DRAINAGE AREA. $--1.54 \mathrm{mi}^{2}$.

$\begin{array}{lcccc}\text { DATE } & \begin{array}{c}\text { DISCHARGE } \\ \left(\mathrm{ft}^{3} / \mathrm{s}\right)\end{array} & \text { DATE } & \begin{array}{c}\text { DISCHARGE } \\ \left(\mathrm{ft}^{3} / \mathrm{s}\right)\end{array} & \begin{array}{c}\text { DISCHARGE } \\ \left(\mathrm{ft}{ }^{3} / \mathrm{s}\right)\end{array} \\ 9-8-78 & 0.43 & 5-10-79 & 0.69 & 0.64 \\ 10-13-78 & 0.34 & 11-1-79 & 0.65 & 7-17-80\end{array}$

INDEX NUMBER, --17 .

STATION NAME.--Drawyer Creek Tributary near Armstrong, DE.

LOCATION. - Lat 39 $29^{\prime} 05^{\prime \prime}$, long $75^{\circ} 41^{\prime} 48^{\prime \prime}$, New Castle County, at culvert on Road

No. $427,0.7 \mathrm{mi}$ upstream from Shallcross Lake, and $1.2 \mathrm{mi}$ northeast of Armstrong. CLASSIFICATION. --Miscellaneous measuring site.

PERIOD OF RECORD. - -1978-1980.

DRAINAGE AREA. $--1.79 \mathrm{mi}^{2}$.

DISCHARGE
DATE
$\left(\mathrm{ft}^{3} / \mathrm{s}\right)$

$9-8-78$

$10-13-78$

1.04

0.75

DATE

DISCHARGE

$\left(\mathrm{ft}^{3} / \mathrm{s}\right)$

DATE

DISCHARGE

$5-10-79$

$11-1-79$

1.42

1.09

$2-13-80$

1.45

INDEX NUMBER. --18

STATION NUMBER.--01483170.

STATION NAME.--Drawyer Creek Tributary near Odessa, DE.

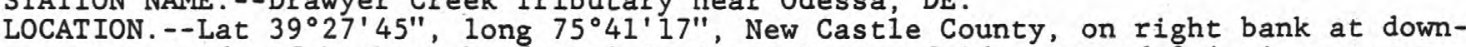
stream side of highway bridge, $1.5 \mathrm{mi}$ northwest of Odessa, and $2.4 \mathrm{mi}$ upstream from mouth.

CLASSIFICATION.--Continuous water-stage station.

PERIOD OF RECORD. --1968-1969, 1974, 1976-1980.

DRAINAGE AREA. $--4.68 \mathrm{mi}^{2}$.

$\begin{array}{cccccc}\text { DATE } & \begin{array}{c}\text { DISCHARGE } \\ \left(\mathrm{ft}^{3} / \mathrm{s}\right)\end{array} & \text { DATE } & \begin{array}{c}\text { DISCHARGE } \\ \left(\mathrm{ft}^{3} / \mathrm{s}\right)\end{array} & \text { DATE } & \begin{array}{c}\text { DISCHARGE } \\ \left(\mathrm{ft}^{3} / \mathrm{s}\right)\end{array} \\ 9-9-68 & 1.73 & 4-15-76 & 3.77 & 9-19-79 & 2.46 \\ 6-2-69 & 2.29 & 9-9-76 & 2.18 & 11-1-19 & 3.34 \\ 7-2-69 & 0.44 & 3-2-77 & 1.69 & 2-13-80 & 3.53 \\ 4-17-74 & 4.91 & 9-7-77 & 1.80 & 4-17-80 & 5.83 \\ 7-26-74 & 2.78 & 3-30-78 & 2.90 & 7-17-80 & 2.26\end{array}$

INDEX NUMBER. - -19 .

STATION NUMBER, --01483200.

STATION NAME.--Blackbird Creek at Blackbird, DE.

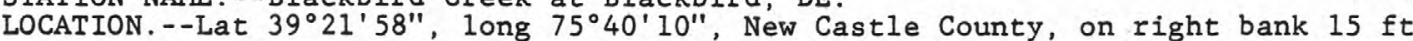

downstream from highway bridge, $0.5 \mathrm{mi}$ upstream from Barlow Branch, $0.6 \mathrm{mi}$

southwest of Blackbird, $5.6 \mathrm{mi}$ northwest of Smyrna, and $13.8 \mathrm{mi}$ upstream from mouth.

CLASSIFICATION, --Continuous water-stage station.

PERIOD OF RECORD. --1957-1958, 1964-1966, 1968, 1973-1974, 1976, 1978-1980.

DRAINAGE AREA. $--3.85 \mathrm{mi}^{2}$.

$\begin{array}{cccccc}\text { DATE } & \begin{array}{c}\text { DISCHARGE } \\ \left(\mathrm{ft}^{3} / \mathrm{s}\right)\end{array} & \text { DATE } & \begin{array}{c}\text { DISCHARGE } \\ \left(\mathrm{ft}^{3} / \mathrm{s}\right)\end{array} & \text { DATE } & \begin{array}{c}\text { DISCHARGE } \\ \left(\mathrm{ft}^{3} / \mathrm{s}\right)\end{array} \\ 7-22-57 & 0.183 & 8-31-66 & 0.00 & 2-27-78 & 4.86 \\ 11-17-58 & 3.93 & 4-15-68 & 3.98 & 8-25-78 & 0.79 \\ 10-14-64 & 0.60 & 7-18-73 & 0.61 & 5-10-79 & 3.23 \\ 3-17-65 & 3.07 & 11-11-74 & 2.04 & 2-13-80 & 2.33 \\ 3-17-66 & 1.35 & 12-30-74 & 4.05 & 7-17-80 & 1.25 \\ 7-21-66 & 0.00 & 11-15-76 & 1.54 & & \end{array}$


TABLE 6.--Low-flow discharge at selected surface-water stations in New Castle, County--Continued

INDEX NUMBER. --20 .

STATION NUMBER. - -01495550.

STATION NAME.--Perch Creek near Elkton, MD.

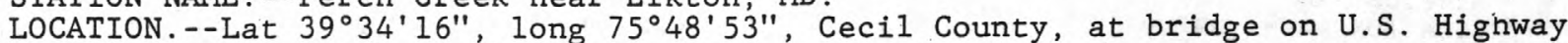
$213,2.5 \mathrm{mi}$ south of E1kton.

CLASSIFICATION. --Low-flow partial-record station.

PERIOD OF RECORD. --1964-1975, 1978-1980.

DRAINAGE AREA. $--5.44 \mathrm{mi}^{2}$.

$\begin{array}{cccccc}\text { DATE } & \begin{array}{c}\text { DISCHARGE } \\ \left(\mathrm{ft}^{3} / \mathrm{s}\right)\end{array} & \text { DATE } & \begin{array}{c}\text { DISCHARGE } \\ \left(\mathrm{ft}^{3} / \mathrm{s}\right)\end{array} & \text { DATE } & \begin{array}{c}\text { DISCHARGE } \\ \left(\mathrm{ft}^{3} / \mathrm{s}\right)\end{array} \\ 9-8-64 & 0.48 & 9-10-68 & 0.94 & 4-25-74 & 5.13 \\ 8-31-65 & 0.34 & 5-28-69 & 1.21 & 9-12-75 & 1.56 \\ 9-29-65 & 0.47 & 9-26-69 & 0.94 & 10-5-78 & 1.29 \\ 7-18-66 & 0.37 & 6-1-70 & 1.78 & 10-12-78 & 1.23 \\ 9-13-66 & 0.27 & 7-7-71 & 1.00 & 5-10-79 & 1.37 \\ 5-2-67 & 3.81 & 9-27-72 & 1.08 & 2-13-80 & 3.27 \\ 7-26-68 & 1.08 & 9-10-73 & 1.38 & - & \end{array}$

INDEX NUMBER. --21 .

STATION NAME.--Back Creek near Mt. Pleasant, DE.

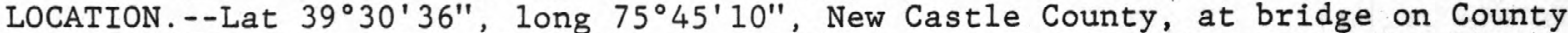

Road $435,1.7 \mathrm{mi}$ upstream from Maryland state line, $2.3 \mathrm{mi}$ west of Mt. Pleasant, $\mathrm{DE}$, and $3.5 \mathrm{mi}$ southeast of Chesapeake City, Maryland.

CLASSIFICATION.--Miscellaneous measuring site.

PERIOD OF RECORD. --1968-1970, 1978-1980.

DRAINAGE AREA. $--4.40 \mathrm{mi}^{2}$.

$\begin{array}{cc}\text { DISCHARGE } \\ \text { DATE } & \left(\mathrm{ft}^{3} / \mathrm{s}\right)\end{array}$

$9-9-68$

$4-15-69$

$7-2-69$

$9-24-69$
1. 34
2.00
0.92
1. 16

DATE

5-6-70

$6-2-70$

$9-3-70$

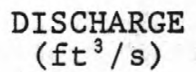

3. 21

2. 50

1. 31
DATE

$10-5-78$

$5-10-79$

2-13-80
DISCHARGE $\left(\mathrm{ft}^{3} / \mathrm{s}\right)$

1.89

3.35

2. 90

INDEX NUMBER. - - 22 .

STATION NUMBER. --01495800.

STATION NAME.--Long Creek near Chesapeake City, MD.

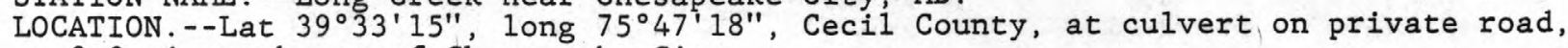
$2.0 \mathrm{mi}$ northeast of Chesapeake City.

CLASSIFICATION.--Continuous water-stage station.

PERIOD OF RECORD. --1978-1980.

DRAINAGE AREA. $--4.36 \mathrm{mi}^{2}$.

\begin{tabular}{|c|c|c|c|c|c|}
\hline DATE & $\begin{array}{c}\text { DISCHARGE } \\
\left(\mathrm{ft}^{3} / \mathrm{s}\right)\end{array}$ & DATE & $\begin{array}{c}\text { DISCHARGE } \\
\left(\mathrm{ft}^{3} / \mathrm{s}\right)\end{array}$ & DATE & $\begin{array}{l}\text { DISCHARGE } \\
\left(\mathrm{ft}^{3} / \mathrm{s}\right)\end{array}$ \\
\hline $\begin{array}{l}9-7-78 \\
10-12-78\end{array}$ & $\begin{array}{l}0.50 \\
0.34\end{array}$ & $\begin{array}{l}5-10-79 \\
2-13-80\end{array}$ & $\begin{array}{l}1.51 \\
2.29\end{array}$ & $7-17-80$ & 0.66 \\
\hline
\end{tabular}




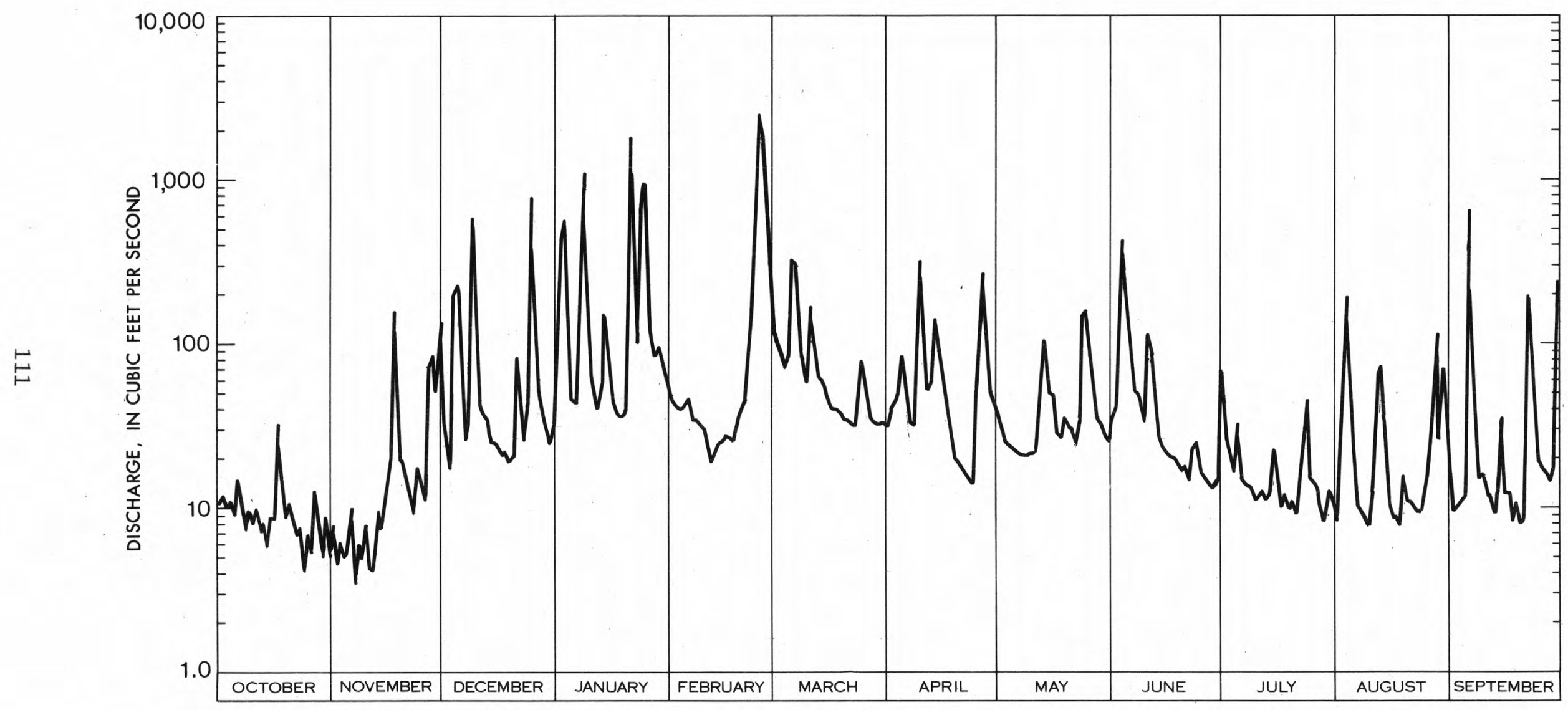

Figure 69.--Stream discharge at station 01478040, Christina River near Bear, De1., water year 1979 . 


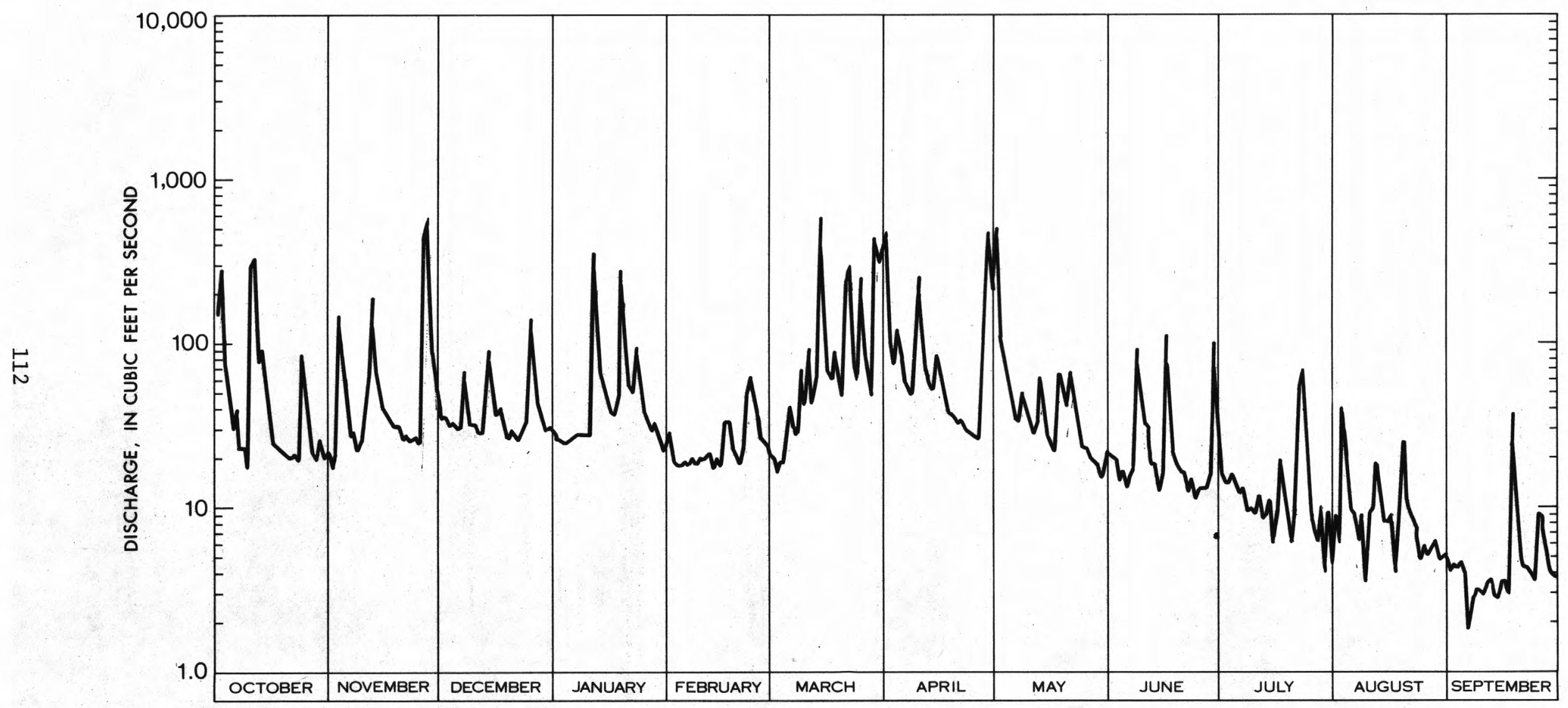

Figure 70.--Stream discharge at station 01478040, Christina River near Bear, Del., water year 1980 . 


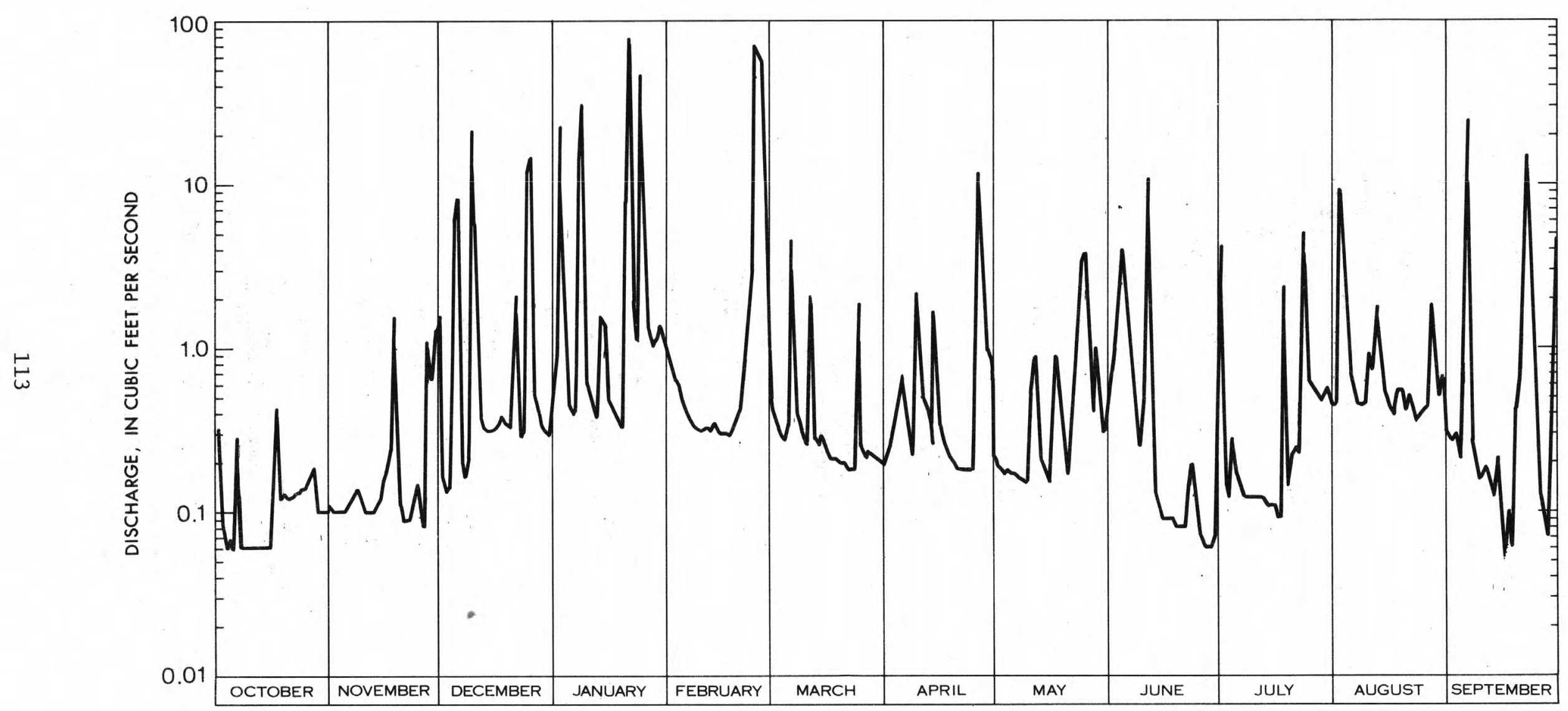

Figure 71.--Stream discharge at station 01482200, Army Creek at State Road, De1., water year 1979 . 


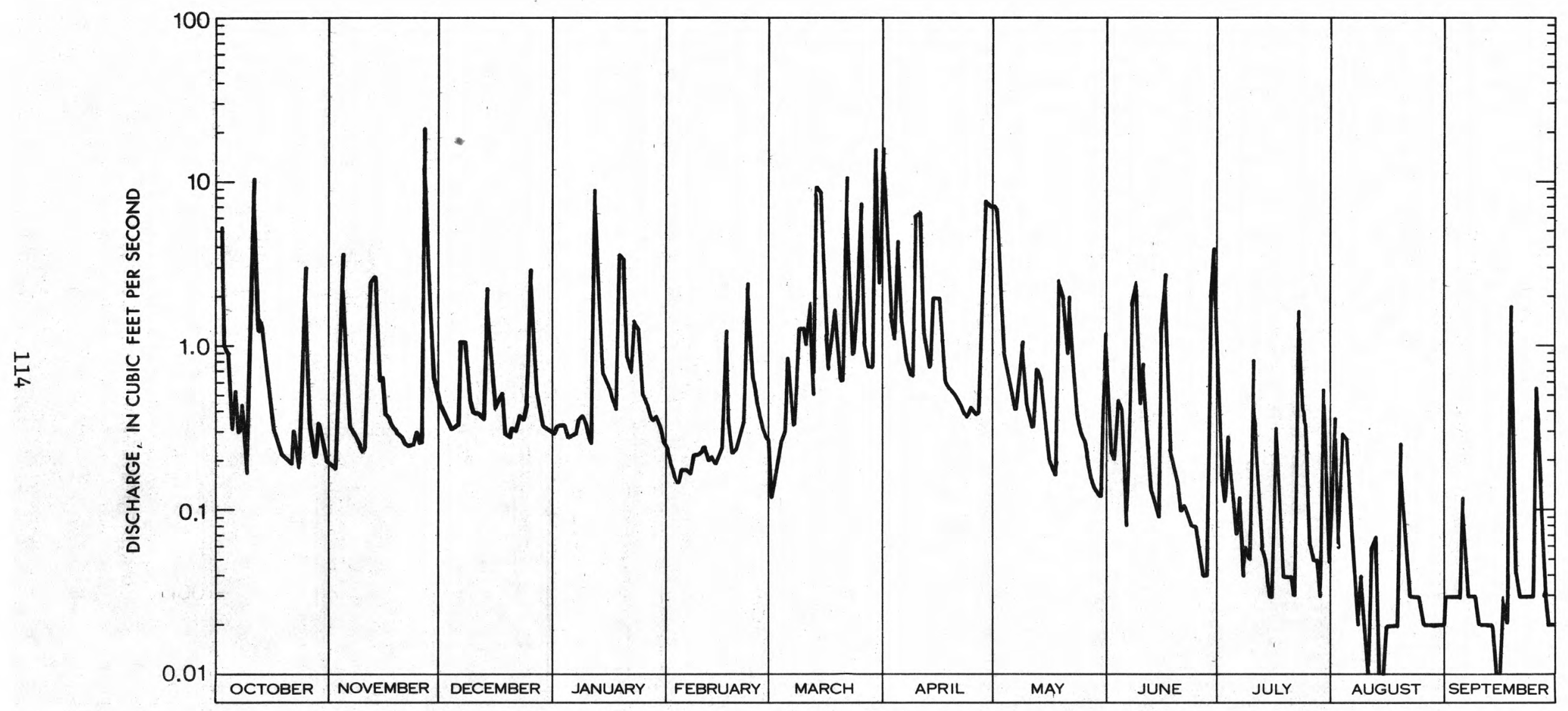

Figure 72.--Stream discharge at station 01482200, Army Creek at State Road, Del., water year 1980 . 


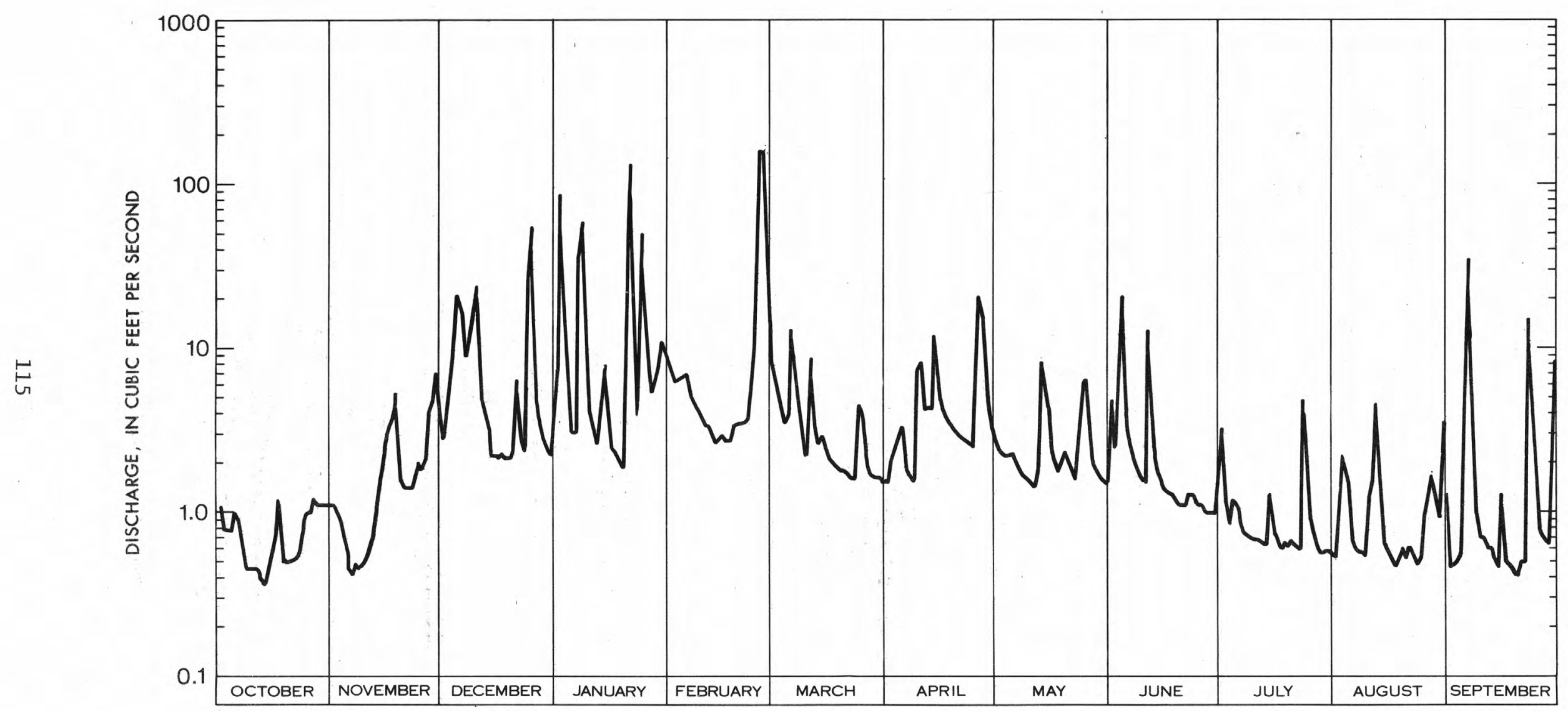

Figure 73.--Stream discharge at station 01482298, Red Lion Creek near Red Lion, De1., water year 1979 . 


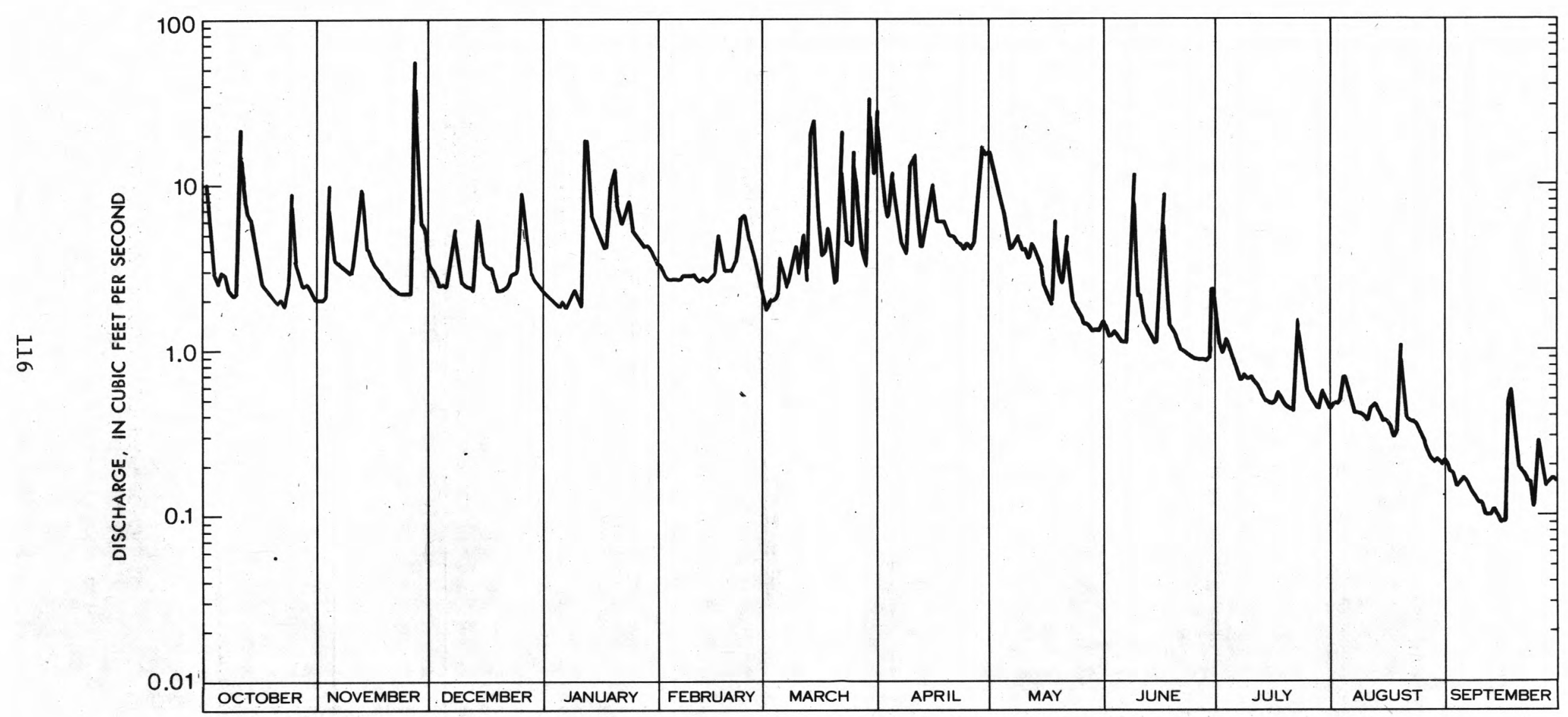

Figure 74.--Stream discharge at station 01482298, Red Lion Creek near Red Lion, De1., water year 1980. 


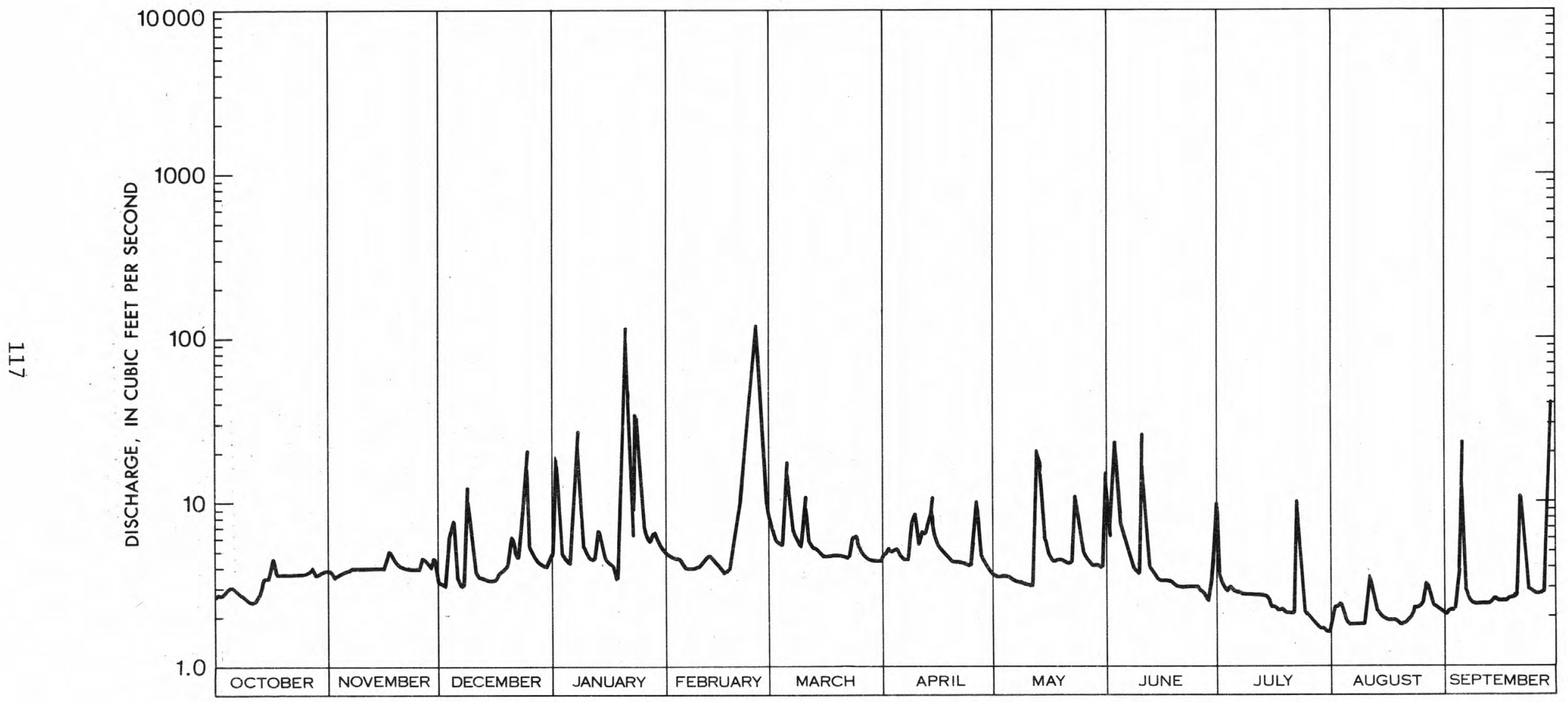

Figure 75.--Stream discharge at station 01483170, Drawyer Creek Tributary near Odessa, De1., water year 1979. 


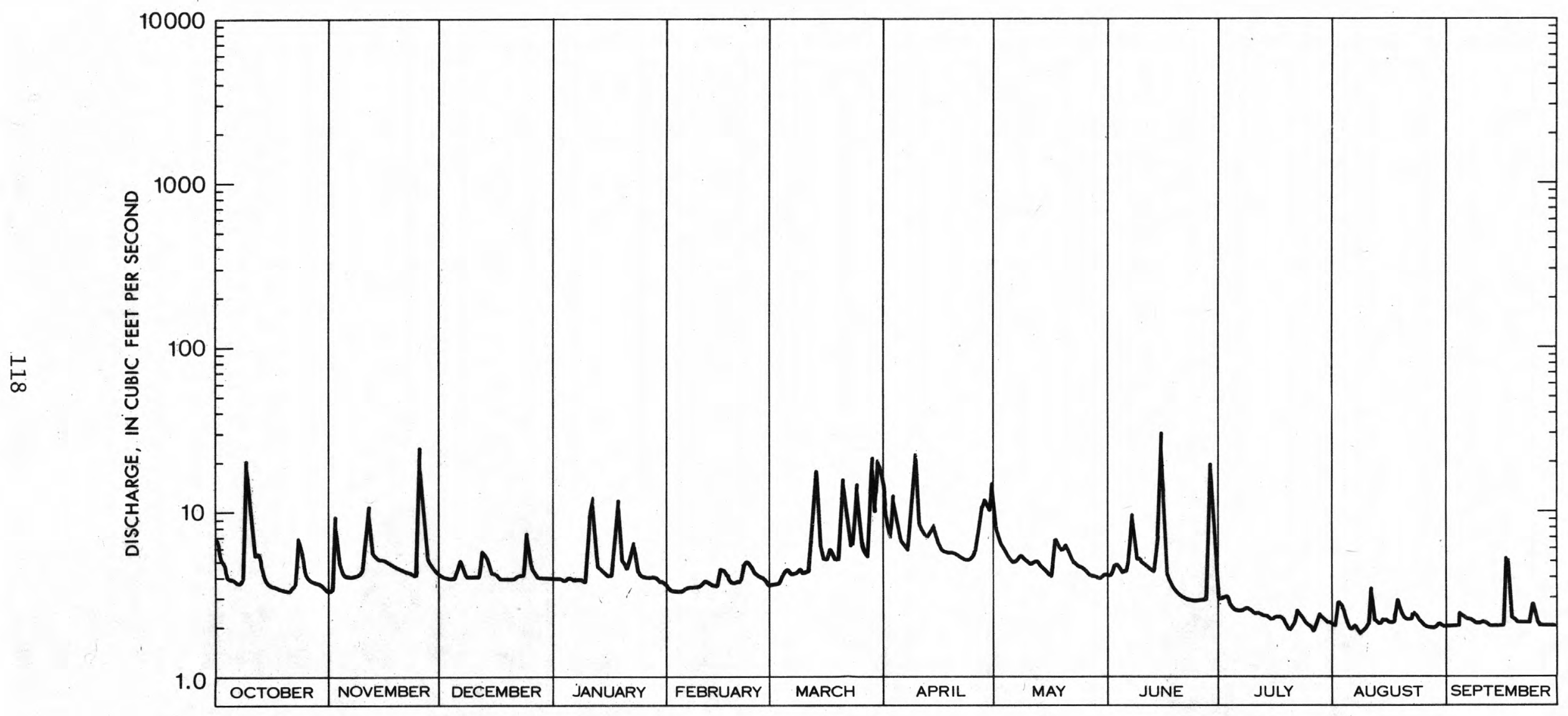

Figure 76.--Stream discharge at station 01483170, Drawyer Creek Tributary near Odessa, Del., water year 1980. 


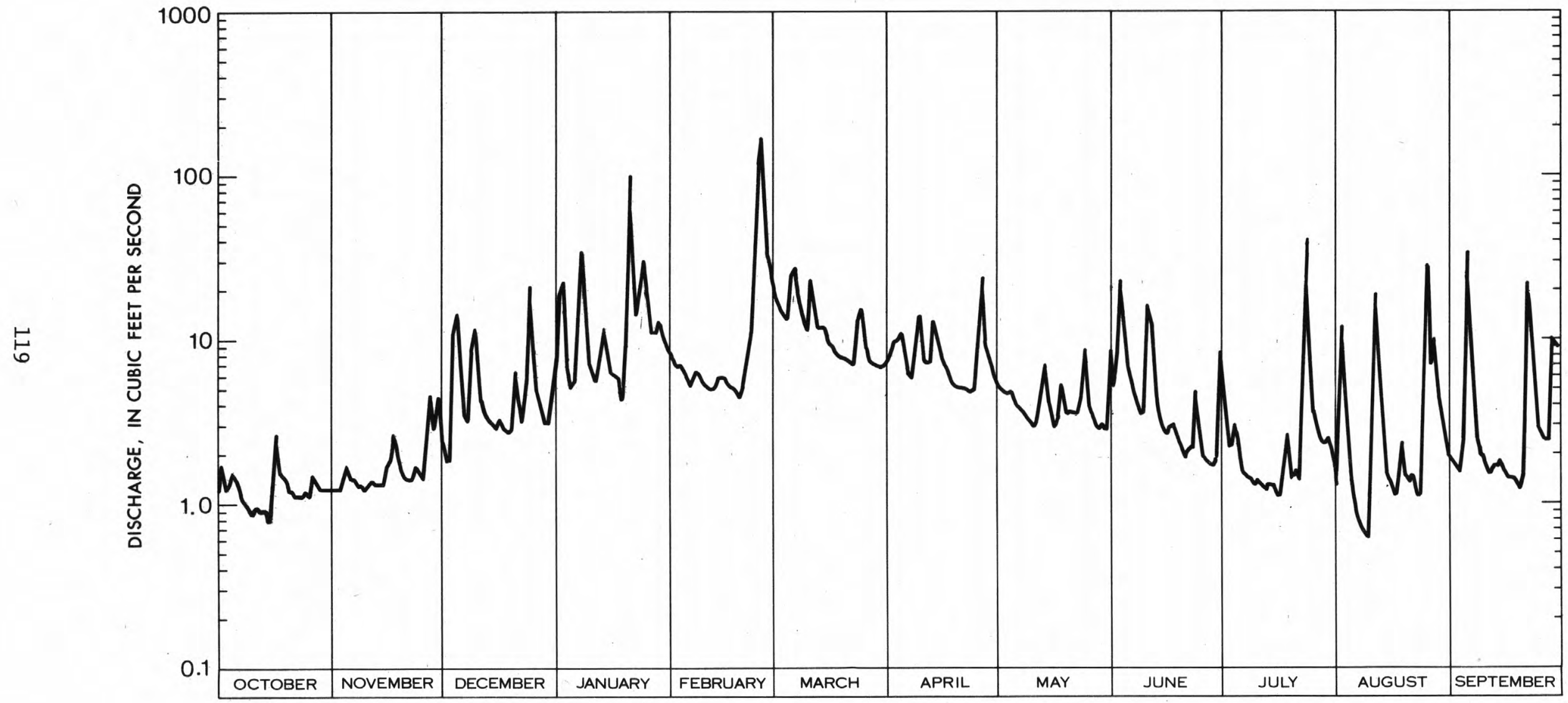

Figure 77.--Stream discharge at station 01483200, Blackbird Creek at B1ackbird, Del., water year 1979 . 


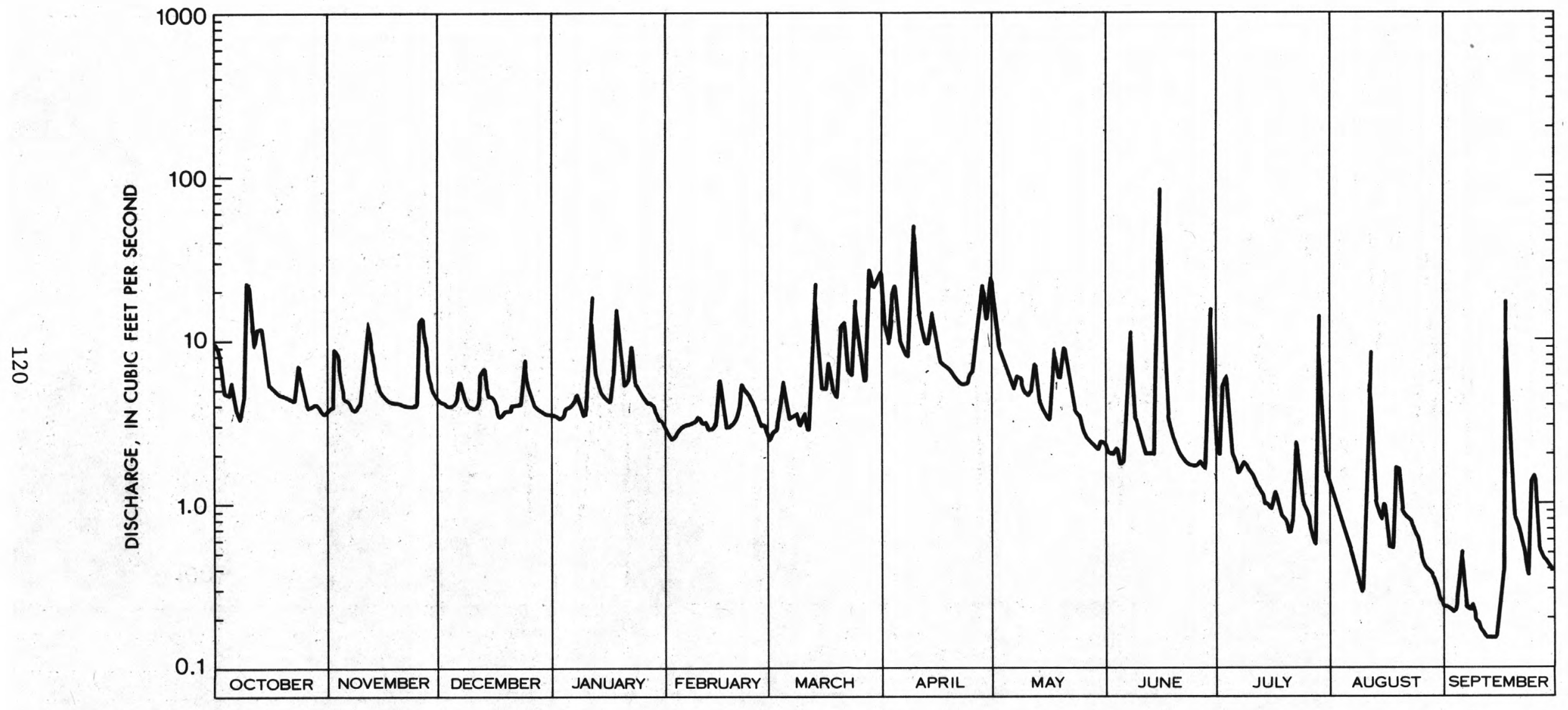

Figure 78.--Stream discharge at station 01483200, Blackbird Creek at Blackbird, Del., water year 1980 . 


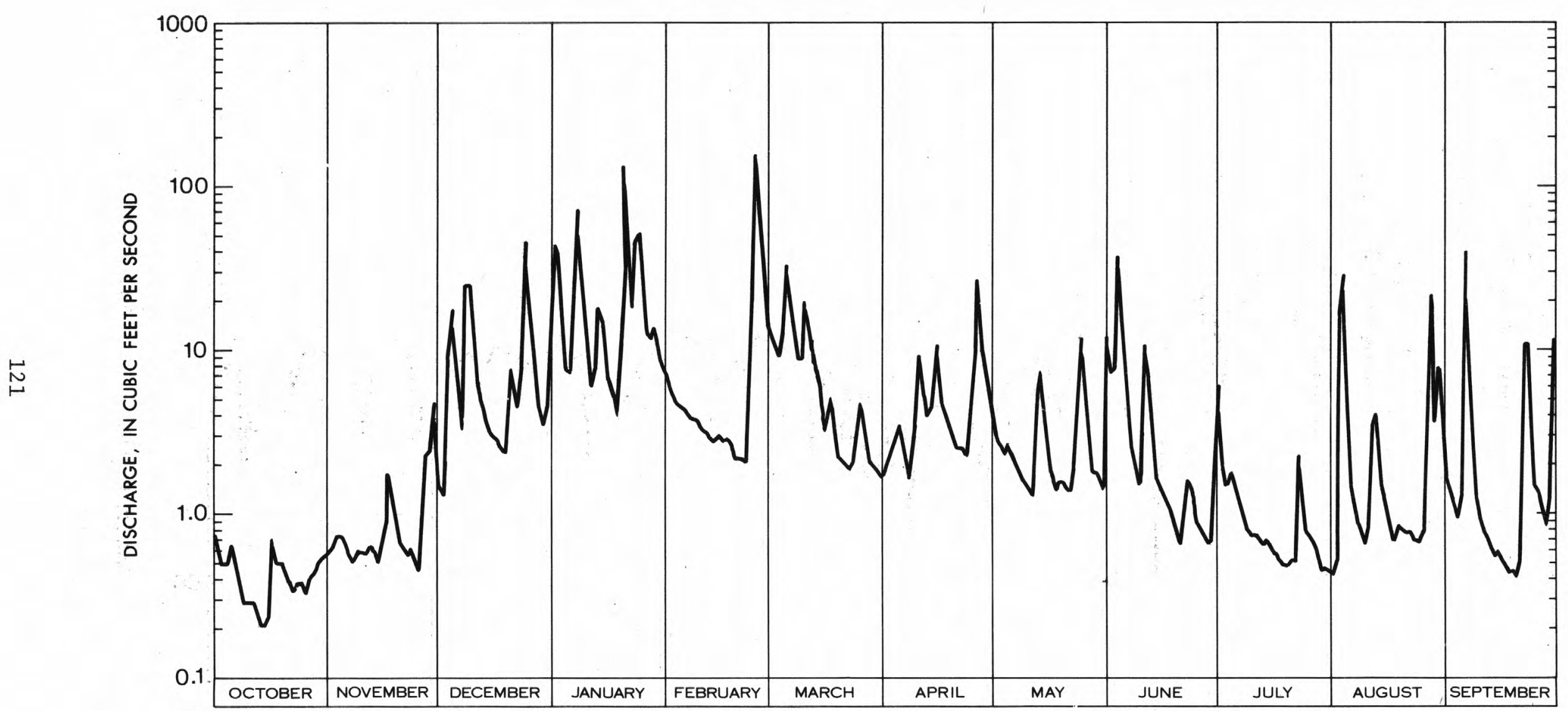

Figure 79.--Stream discharge at station 01495800, Long Creek near Chesapeake City, Md., water year 1979. 


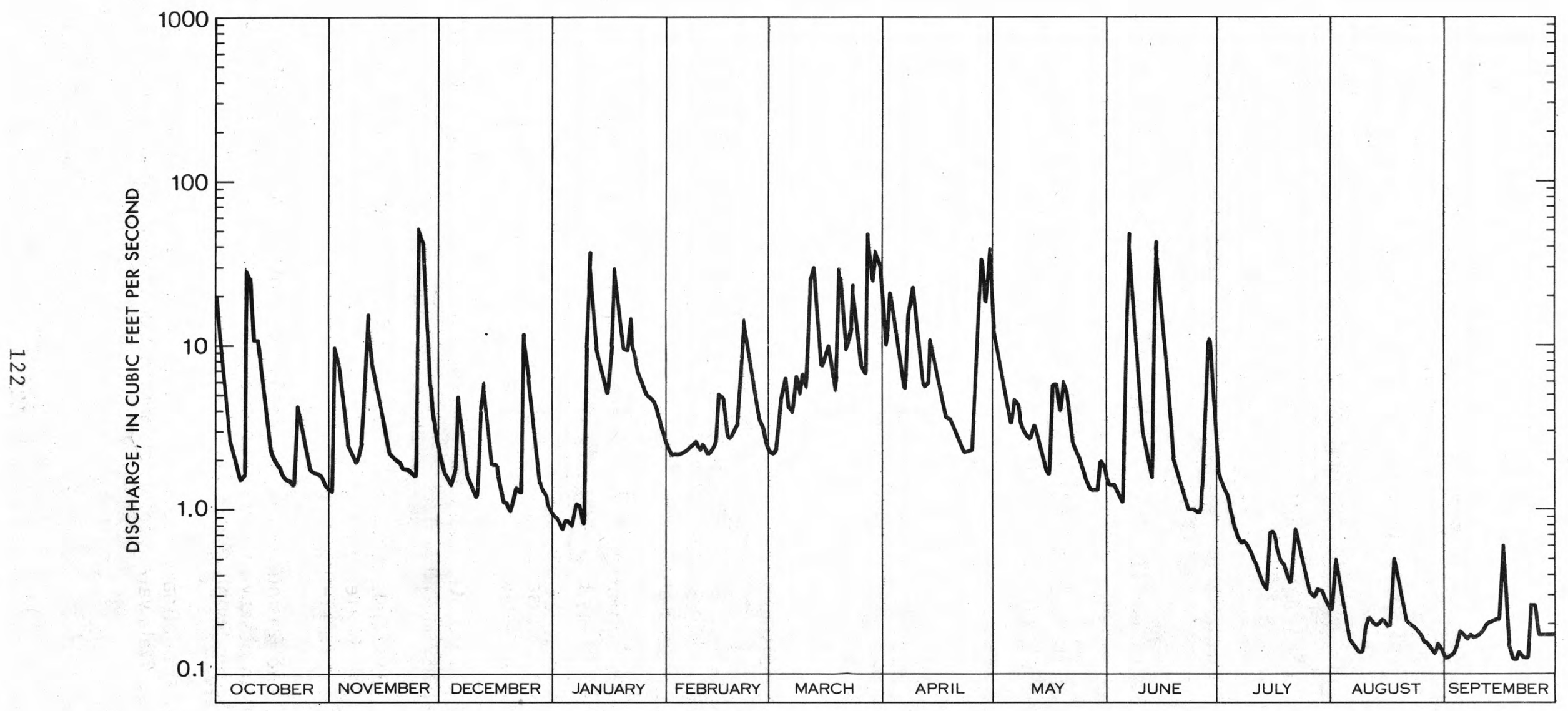

Figure 80.--Stream discharge at station 01495800, Long Creek near Chesapeake City, Md., water year 1980 . 


\section{SELECTED BIBLIOGRAPHY}

Back, William, 1966, Hydrochemical facies and ground-water flow patterns in northern part of Atlantic Coastal Plain - Hydrology of aquifer systems: U.S. Geological Survey Professional Paper 498-A, 42 p.

Boggess, D. H., and Coskery, O. J., 1956, Delaware, in Water levels and artesian pressures in observation wells in the United States, 1954: U.S. Geological Survey Water-Supply Paper 1321, p. 13-22.

Coskery, O. J., 1957, Delaware, in Water levels and artesian pressures in observation wells in the United States, 1955: U.S. Geological Survey WaterSupply Paper 1404, p. 13-21.

1960, Delaware, in Ground-water levels in the United States, 1956-57: U.S. Geological Survey Water-Supply Paper 1537, p. 9-15.

1961, Water levels in Delaware - 1958: Delaware Geological Survey Water-Level Report No. 7, 17 p.

Cushing, E. M., Kantrowitz, I. H., and Taylor, K. R., 1973, Water resources of the Delmarva Peninsula: U.S. Geological Survey Professional Paper 822, 58 p.

Groot, J. J., 1955, Sedimentary petrology of the Cretaceous sediments of northern Delaware in relation to paleographic problems: Delaware Geological Survey Bulletin 5, $157 \mathrm{p}$.

Groot, J. J., and Rasmussen, W. C., 1954, Geology and ground-water resources of the Newark area, Delaware: Delaware Geological Survey Bulletin 2, 133 p.

Groot, J. J., Organist, D. M., and Richards, H. G., 1954, Marine Upper Cretaceous Formations of the Chesapeake and Delaware Canal: Delaware Geological Survey Bulletin 3 and Third Annual Report, 64 p.

Jordan, R. R., 1962, Stratigraphy of the sedimentary rocks of Delaware: Delaware Geological Survey Bulletin 9, 51 p.

Kraft, J. C., and Maisano, M. D., 1968, A geologic cross section of Delaware: University of Delaware, Water Resources Center, horizontal scale 1:146,500.

Lohman, S. W., 1979, Ground-water hydraulics: U.S. Geological Survey Professional Paper 708, 70 p.

Marine, I. W., 1955, Delaware, in Water levels and artesian pressures in observation wells in the United States in 1952: U.S. Geological Survey Water-Supply Paper 1221, p. 11-18.

Marine, I. W., and Rasmussen, W. C., 1954, Delaware, in Water levels and artesian pressures in observation wells in the United States in 1951: U.S. Geological Survey Water-Supply Paper 1191, p. 11-16.

1955, Preliminary report on the geology and ground-water resources of Delaware: Delaware Geological Survey Bulletin 4, 336 p. 
Minard, J. P., Sohl, N. F., and Owens, J. P., 1977, Reintroduction of the Severn Formation (Upper Cretaceous) to replace the Monmouth Formation in Maryland, in Changes in stratigraphic nomenclature by the U.S. Geological Survey, 1976: U.S. Geological Survey Bulletin 1435A, p. A132-A133.

Owens, J. P., and Denny, C. S., 1979, Upper Cenozoic deposits of the central Delmarva Peninsula, Maryland and Delaware: U.S. Geological Survey Professional Paper 1067-A, 28 p.

Owens, J. P., and Minard, J. P., 1979, Upper Cenozoic sediments of the lower Delaware Valley and the northern Delmarva Peninsula, New Jersey, Pennsylvania, Delaware, and Maryland: U.S. Geological Survey Professional Paper 1067-D, 47 p.

Parker, G. G., Hely, A. G., Keighton, W. B., Olmsted, F. H., and others, 1964, Water resources of the Delaware River Basin: U.S. Geological Survey Professional Paper 381, 200 p.

Pickett, T. E., 1970, Geology of the Chesapeake and Delaware Canal area, Delaware: Delaware Geological Survey, Geologic Map Series, no. 1, scale $1: 24,000$.

Pickett, T. E., and Spoljaric, Nenad, 1971, Geology of the Middletown-Odessa area, Delaware: Delaware Geological Survey, Geologic Map Series, no. 2, scale $1: 24,000$.

Rasmussen, W. C., Groot, J. J., and Beamer, N. H., 1958, Wells for the observation of chloride and water levels in aquifers that cross the Chesapeake and Delaware Canal: Delaware Geological Survey Report of Investigations No. 3, $22 \mathrm{P}$.

Rasmussen, W. C., Groot, J. J., Martin, R. O. R., and others, 1957, The water resources of northern Delaware: Delaware Geological Survey Bulletin 6, v. 1, $223 \mathrm{p}$.

Rima, D. R., Coskery, O. J., and Anderson, P. W., 1964, Ground-water resources of southern New Castle County, Delaware: U.S. Geological Survey WaterSupply Paper 1756, 54 p.

Spoljaric, Nenad, 1967, Pleistocene channels of New Castle County: Delaware Geological Survey Report of Investigations No. 10, 15 p.

1967, Quantitative lithofacies analysis of Potomac Formation, Delaware: Delaware Geological Survey Report of Investigations No. 12, 26 p.

1972, Geology of the Fall Zone in Delaware: Delaware Geological Survey Report of Investigations No. 19, 30 p.

Sundstrom, R. W., 1974, Water resources in the vicinity of a solid-waste landfill in the Midvale-Llangollen Estates area, New Castle County, Delaware: University of Delaware, Water Resources Center, 92 p. 
Sundstrom, R. W., and others, 1967, The availability of ground water from the Potomac Formation in the Chesapeake and Delaware Canal area, Delaware: University of Delaware, Water Resources Center, 95 p.

Sundstrom, R. W., and Pickett, T. E., 1971, The availability of ground water in New Castle County, Delaware: University of Delaware, Water Resources Center, $156 \mathrm{p}$.

Sundstrom, R. W., Pickett, T. E., and Varrin, R. D., 1975, Hydrology, geology and mineral resources of the coastal zone of Delaware: Delaware State Planning Office, Technical Report No. 3, 245 p.

Water Supply Branch, Department of Natural Resources and Environmental Control, 1978, Public water systems in Delaware: State of Delaware, 81 p.

Wolfe, J. A., and Pakiser, H. M., 1971, Stratigraphic interpretations of some Cretaceous microfossil floras of the Middle Atlantic States, in Geological Research 1971: U.S. Geological Survey Professional Paper 750-B, p. B35B47.

Woodruff, K. D., 1969, The occurrence of saline ground water in Delaware aquifers: Delaware Geological Survey Report of Investigations No. 13, 45 p.

1970, General ground-water quality in fresh-water aquifers of Delaware: Delaware Geological Survey Report of Investigations No. 15, 22 p.

1977, Geohydrology of the Newark area, Delaware: Delaware Geological Survey, Hydrologic Map Series, no. 2, Sheet 1- Basic Geology, scale 1:24,000.

1978, Geohydrology of the Newark area, Delaware: Delaware Geological Survey, Hydrologic Map Series, no. 2, Sheet 2-Hydrologic Data, scale $1: 24,000$.

Woodruff, K. D., Miller, J. C., Jordan, R. R., Spoljaric, Nenad, and Pickett, T. E., 1972, Geology and ground water, University of Delaware, Newark, Delaware: Delaware Geological Survey Report of Investigations No. 18, 40 p.

Woodruff, K. D., and Thompson, A. M., 1972, Geology of the Newark area, Delaware: Delaware Geological Survey, Geologic Map Series, no. 3, scale 1:24,000.

1975, Geology of the Wilmington area, Delaware: Delaware Geological Survey, Geologic Map Series, no. 4, scale 1:24,000. 
TABLE 7. Partial record of wolls in the Potomac Formation in New Castle County

DGS Wel1 Number: Well number assigned by the Delaware Geological Survey; N.A., no DGS well number assigned.

Local Well Number: Well number assigned by owner; $\{$, two or more wells with individual local well numbers but one DGS Type: C,

, domestic; G, county, state or federal government; I, industrial; M, municipa1.

S public water supply.

Use: 0, observation; $P$, production; R, recovery; T, test; U, unknown. Status: A, abandoned; E, emergency or stand-by; N, not in use; Op, operating; W, water-level observation; U, unknown Screen Interval:

Elevation, Land Surface and Measuring Point: In feet above sea level.

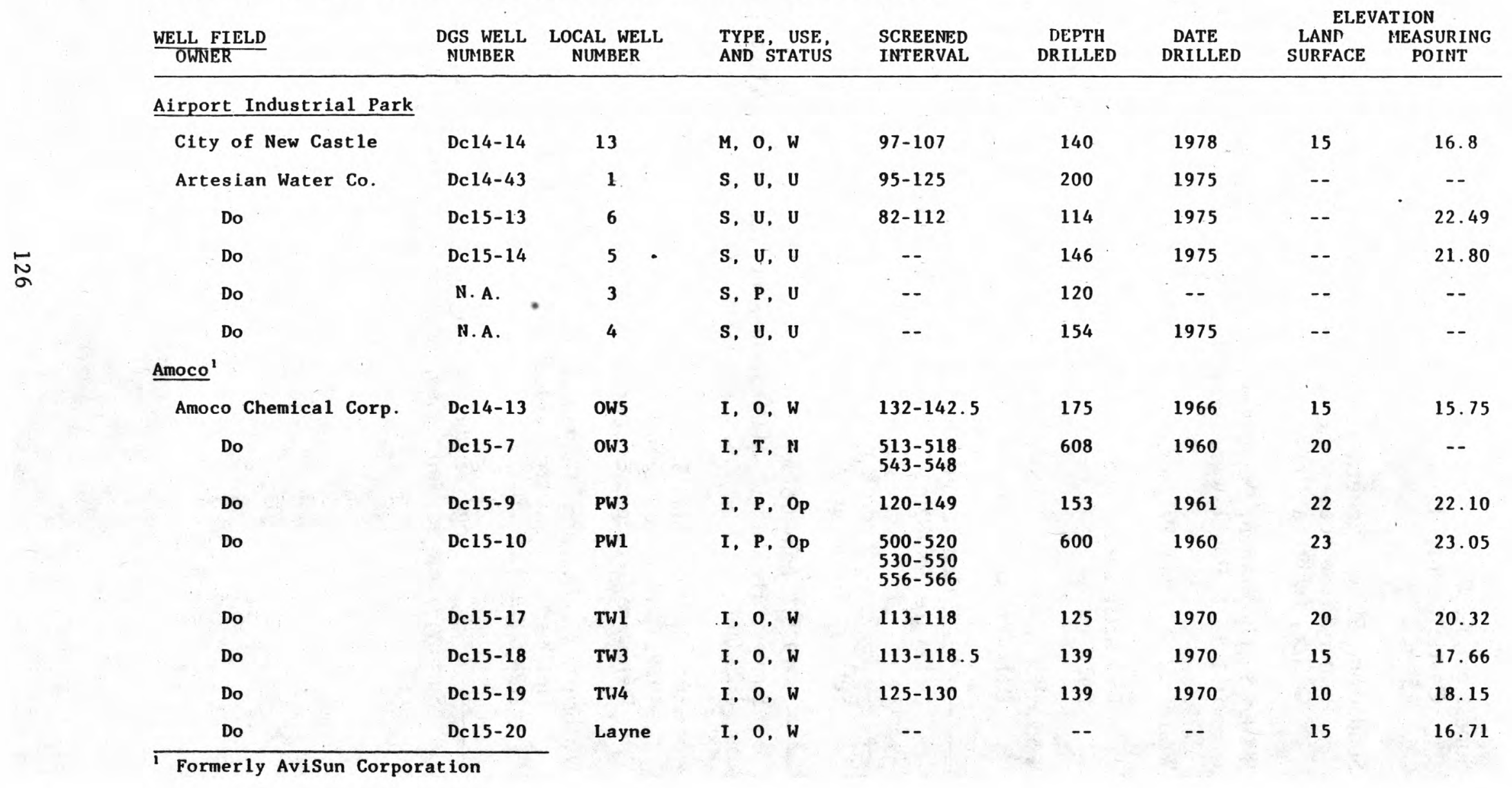


TABLE 7.--Partial record of wells in the Potomac Formation in New Castle County--Continued

\begin{tabular}{|c|c|c|c|c|c|c|c|c|}
\hline \multirow[b]{2}{*}{$\frac{\text { WELL FIELD }}{\text { OWNER }}$} & \multirow[b]{2}{*}{$\begin{array}{l}\text { DGS WELL } \\
\text { NUMBER }\end{array}$} & \multirow[b]{2}{*}{$\begin{array}{l}\text { LOCAL WELL } \\
\text { NUMBER }\end{array}$} & \multirow[b]{2}{*}{$\begin{array}{l}\text { TYPE, USE, } \\
\text { AND STATUS }\end{array}$} & \multirow[b]{2}{*}{$\begin{array}{l}\text { SCREENT:D } \\
\text { INTERVAL }\end{array}$} & \multirow[b]{2}{*}{$\begin{array}{l}\text { DEPTH } \\
\text { DRILLED }\end{array}$} & \multirow[b]{2}{*}{$\begin{array}{l}\text { DATE } \\
\text { DRILLED }\end{array}$} & \multicolumn{2}{|c|}{ ELEVATION } \\
\hline & & & & & & & $\begin{array}{l}\text { LAND } \\
\text { SURFACE }\end{array}$ & $\begin{array}{l}\text { MEASURING } \\
\text { POINT }\end{array}$ \\
\hline \multicolumn{9}{|l|}{$\underline{\text { Amoco }}$} \\
\hline Amoco Chemical Corp. & Dc24-6 & OW4 & $I, 0, W$ & $139-144$ & 187 & 1960 & 40 & 40.88 \\
\hline Do & Dc25-16 & ow2 & $\mathbf{I}, \mathbf{T}, \mathbf{N}$ & $\begin{array}{l}525-530 \\
552-557\end{array}$ & 664 & 1960 & 30 & -- \\
\hline Do & Dc25-17 & PW2 & $I, P, O_{p}$ & $129-169$ & 174 & 1961 & 25 & 25.46 \\
\hline \multicolumn{9}{|l|}{ Army Creek Landfill ${ }^{2}$} \\
\hline $\begin{array}{l}\text { New Castle County } \\
\text { Dept. of Public Works }\end{array}$ & Dc13-9 & $5 A$ & $G, 0, W$ & $70-80$ & 124 & 1972 & 11.5 & 11.76 \\
\hline Do & Dc14-18 & $\left\{\begin{array}{l}2 \mathrm{~A} \\
2 \mathrm{~B}\end{array}\right.$ & $\begin{array}{ll}G, & 0, \\
G, & 0,\end{array}$ & $\begin{array}{l}80-88 \\
45-55\end{array}$ & $\begin{array}{l}99 \\
55\end{array}$ & $\begin{array}{l}1972 \\
1972\end{array}$ & $\begin{array}{l}17.3 \\
17.3\end{array}$ & $\begin{array}{l}17.58 \\
17.19\end{array}$ \\
\hline Do & Dc14-16 & $1 \mathrm{~B}$ & $G, 0, W$ & $56-66$ & 66 & 1972 & 7.0 & 8.21 \\
\hline Do & Dc14-17 & $1 \mathrm{~A}$ & $G, 0, W$ & $94.5-104.5$ & 112 & 1972 & 7.0 & 7.94 \\
\hline Do & Dc14-19 & $3 \mathrm{~A}$ & $G, 0, W$ & $74.5-84.5$ & 85 & 1972 & 13.0 & 13.15 \\
\hline Do & Dc14-20 & $\left\{\begin{array}{l}4 \mathrm{~A} \\
4 \mathrm{~B}\end{array}\right.$ & $\begin{array}{lll}G, & 0, & U \\
G, & 0, & U\end{array}$ & $\begin{array}{l}120-130 \\
72-82\end{array}$ & $\begin{array}{r}136 \\
89\end{array}$ & $\begin{array}{l}1972 \\
1972\end{array}$ & $\begin{array}{l}51.0 \\
51.0\end{array}$ & $\begin{array}{l}52.95 \\
52.63\end{array}$ \\
\hline Do & Dc14-22 & 6 & $G, 0, U$ & $70-79$ & 124 & 1972 & 13.7 & 14.05 \\
\hline Do & Dc14-23 & 7 & $G, \quad 0, \quad \mathrm{U}$ & $105-110$ & 124 & 1972 & 16.0 & 16.11 \\
\hline Do & Dc14-24 & 8 & $G, 0, U$ & $80-90$ & 124 & 1972 & 12.0 & 12.24 \\
\hline Do & Dc14-25 & 9 & $G, 0, U$ & $100-110$ & 124 & 1972 & 5.3 & 5.58 \\
\hline Do & Dc14-26 & 10 & $\mathrm{G}, 0, \mathrm{U}$ & $74-84$ & 124 & 1972 & 18.9 & 19.21 \\
\hline Do & Dc14-27 & 11 & $G, \quad 0, W$ & $60-70$ & 124 & 1972 & 9.0 & 9.93 \\
\hline Do & Dc14-28 & 12 & $G, 0, U$ & $50-58$ & 124 & 1972 & 7.0 & 7.15 \\
\hline Do & Dc14-29 & 13 & $G, 0, \quad \mathrm{U}$ & $50-60$ & 124 & 1972 & 5.0 & 6.0 \\
\hline
\end{tabular}


TABLE 7.--Partial record of wells in the Potomac Formation in New Castle County--Continued

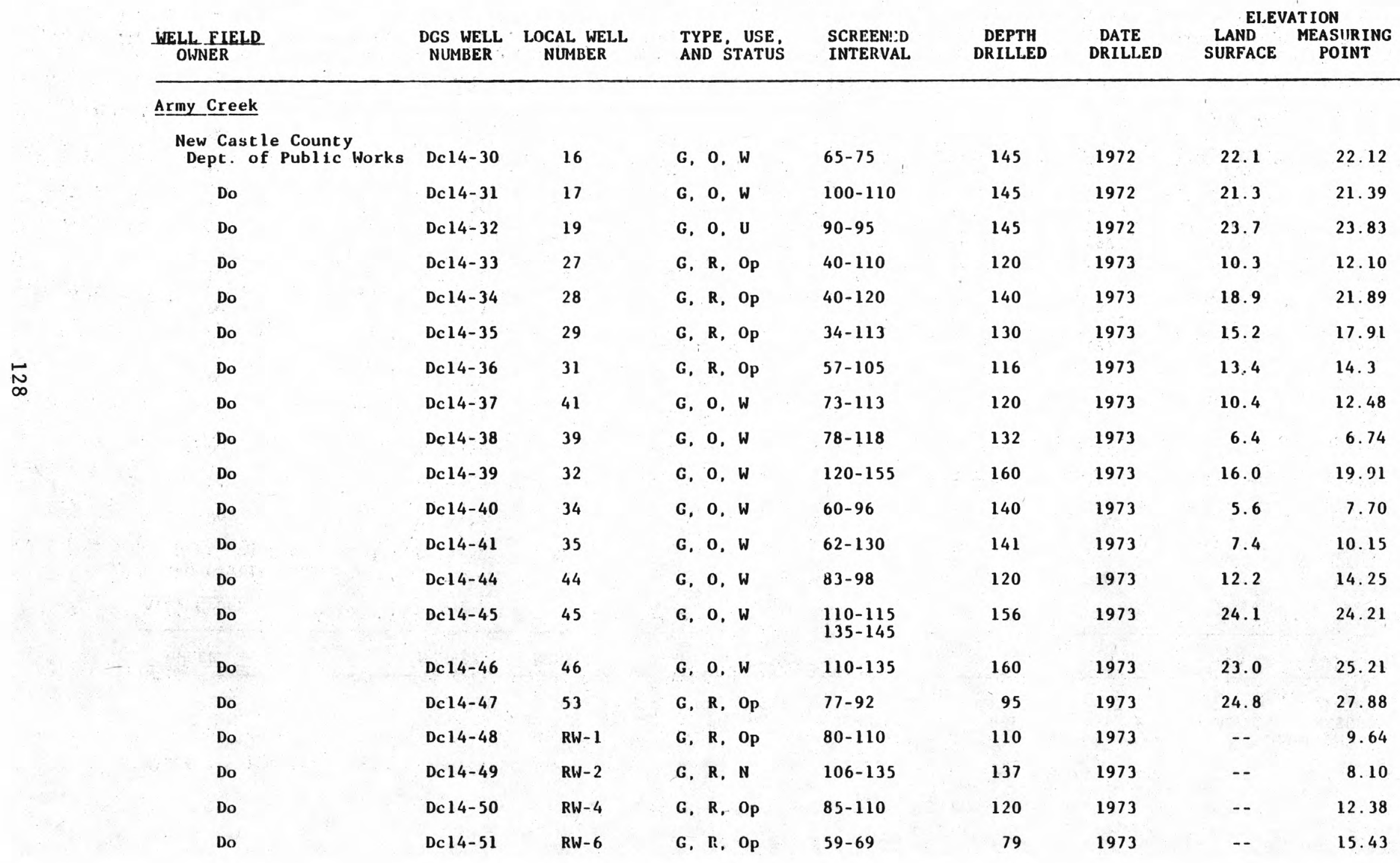


TABLE 7.--Partial record of wells in the Potomac Formation in New Castle County--Continued

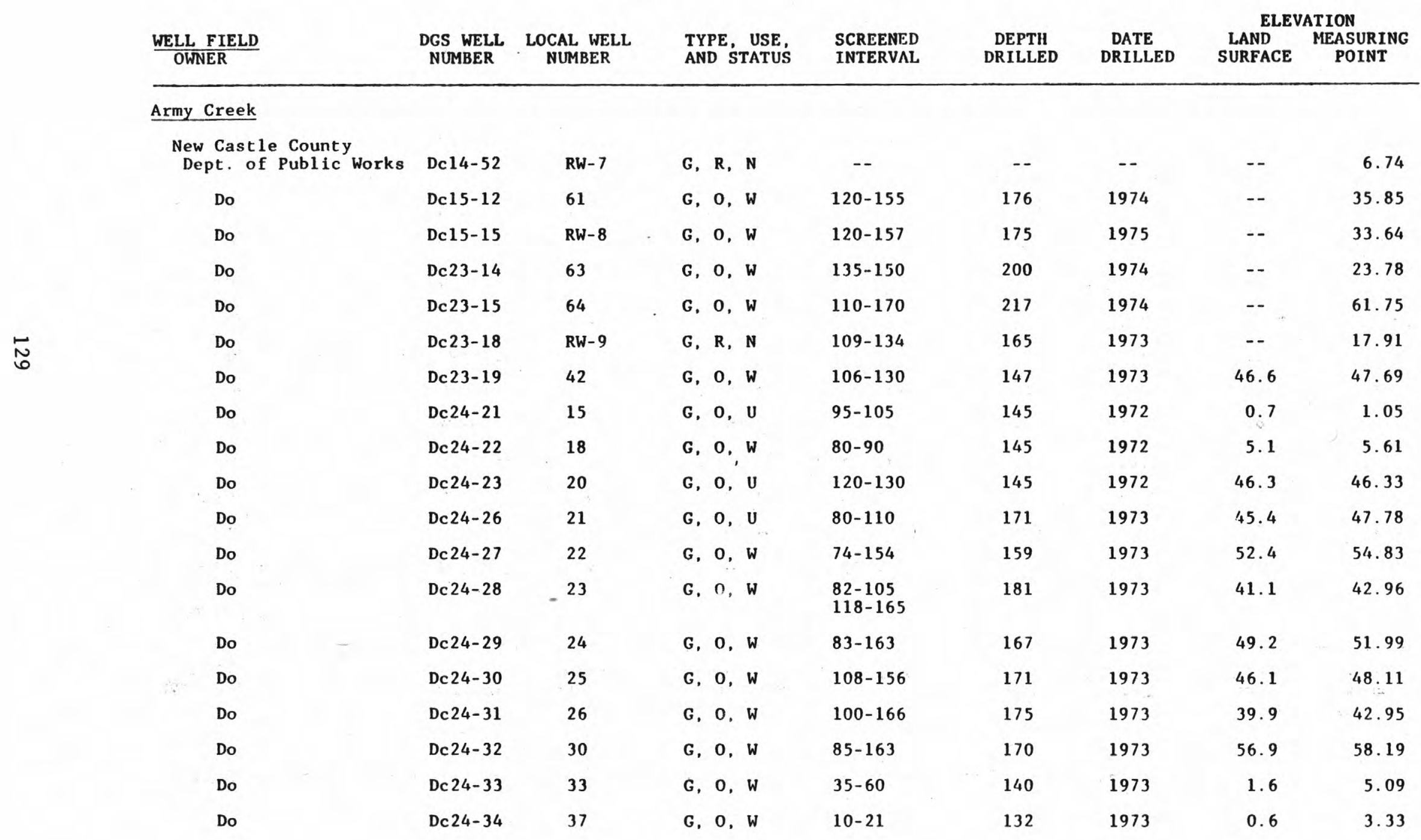


TABLE 7.--Partial record of wells in the Potomac Formation in New Castle County--Continued

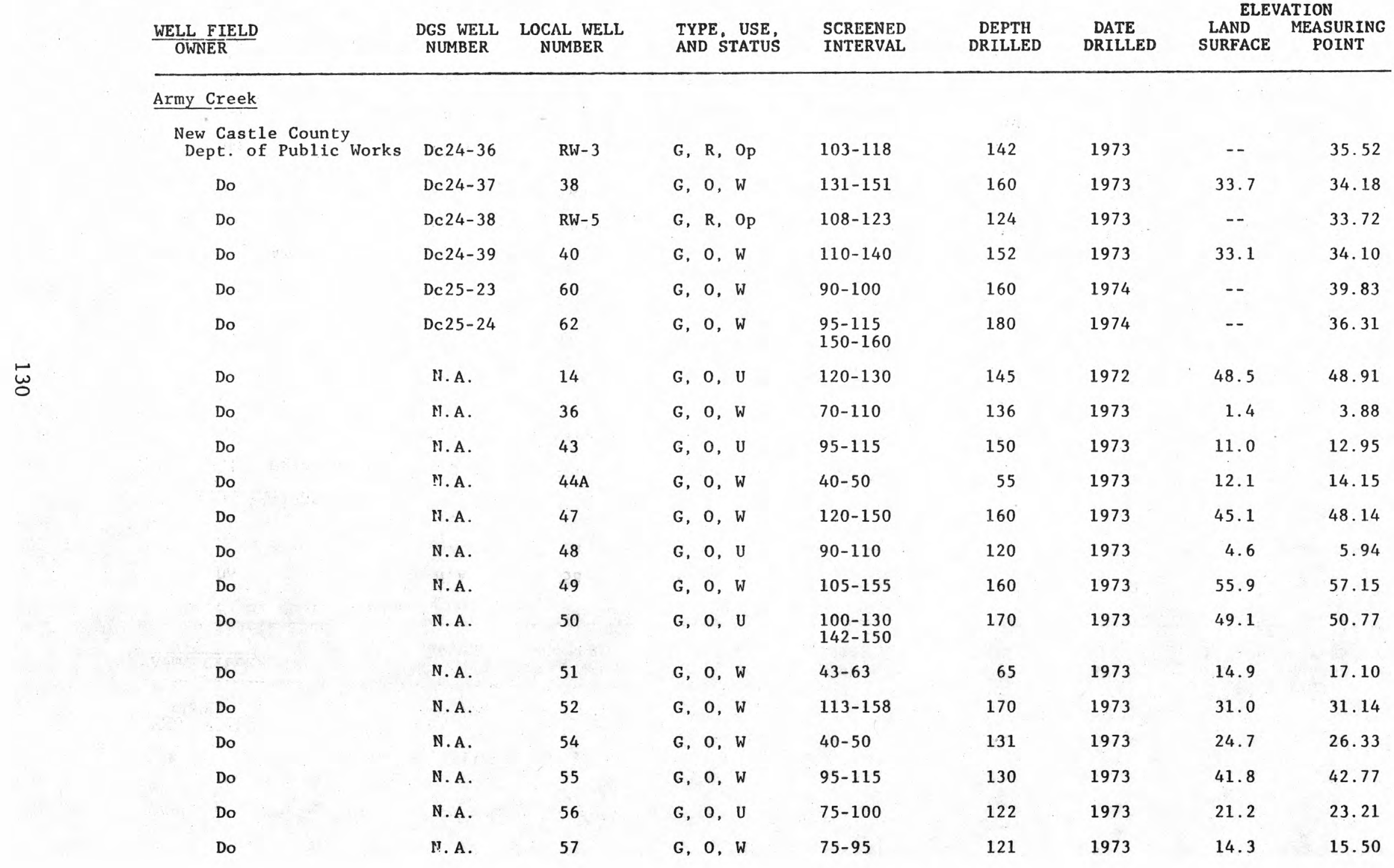


TABLE 7.--Partial record of wells in the Potomac Formation in New Castle County--Continued

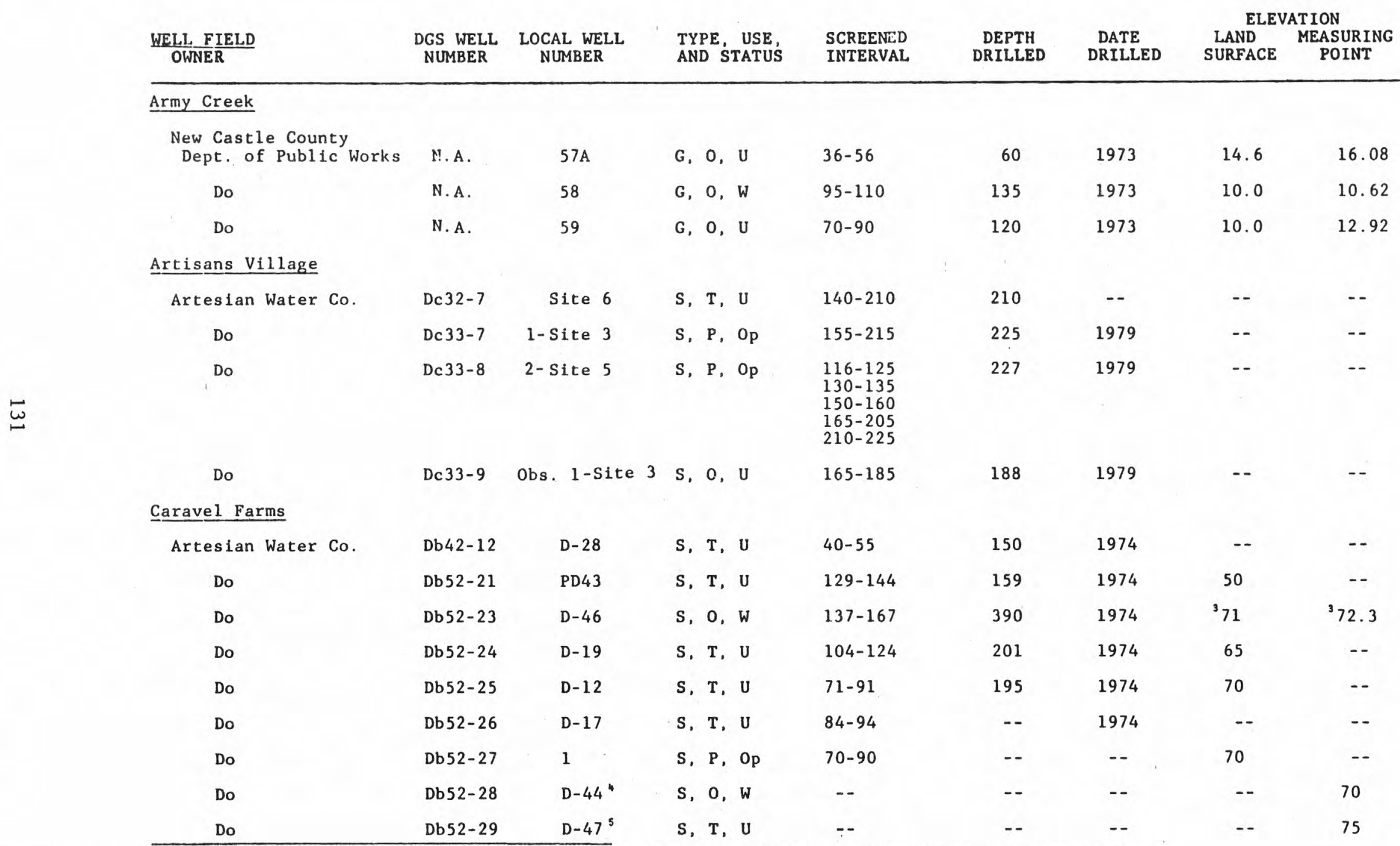

3 Land surface and measuring point elevations prior to 3-18-81 were 74 and 75 ft, respectively.

- No information available.

5 No information available, casing blocked. 
TABLE 7.--Partial record of wells in the Potomac Formation in New Castle County--Continued

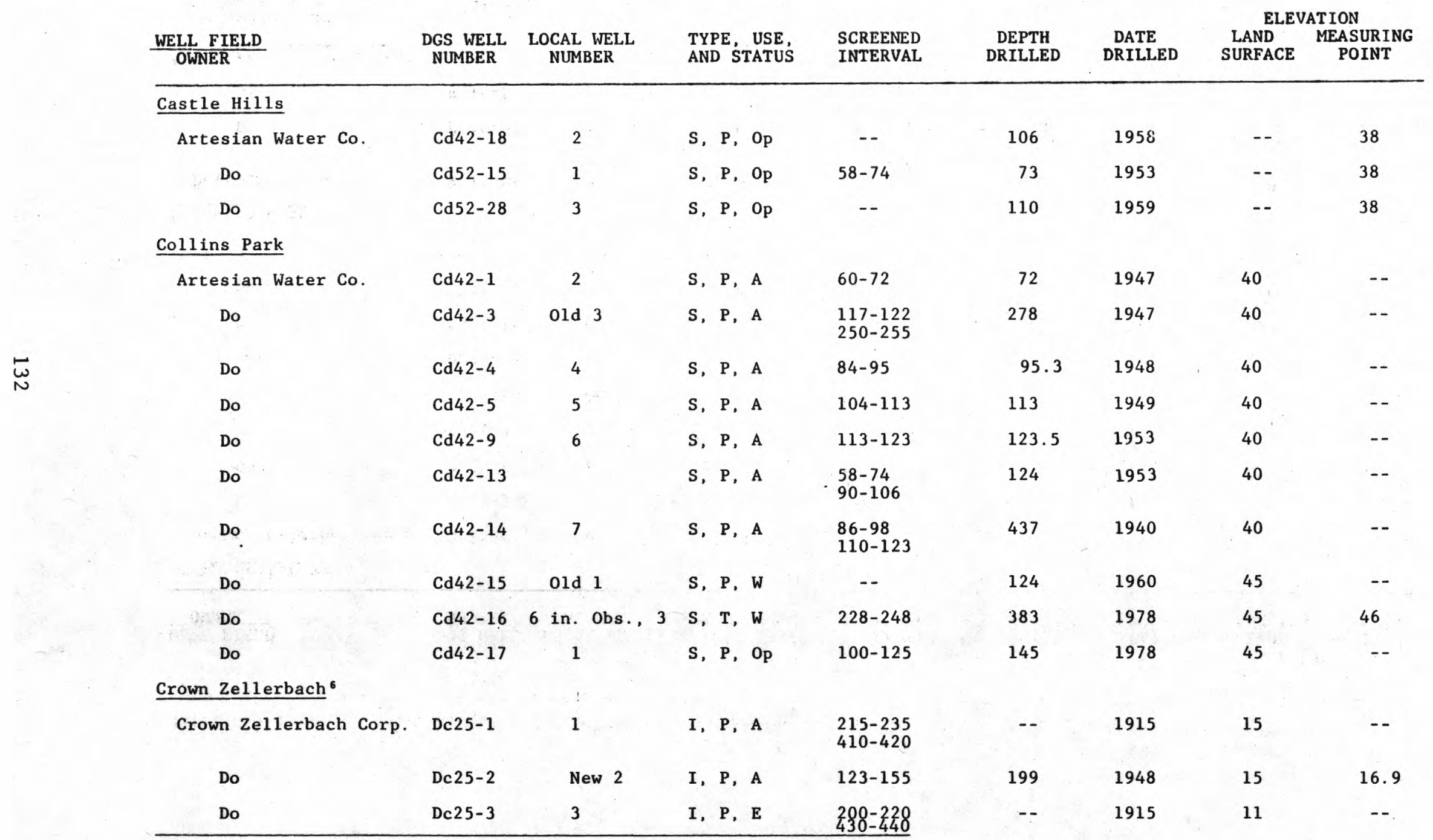

6 Formerly Amoco Film Plant, which was formerly Delaware Rayon Company. 
TABLE 7.--Partial record of wells in the Potomac Formation in New Castle County--Continued

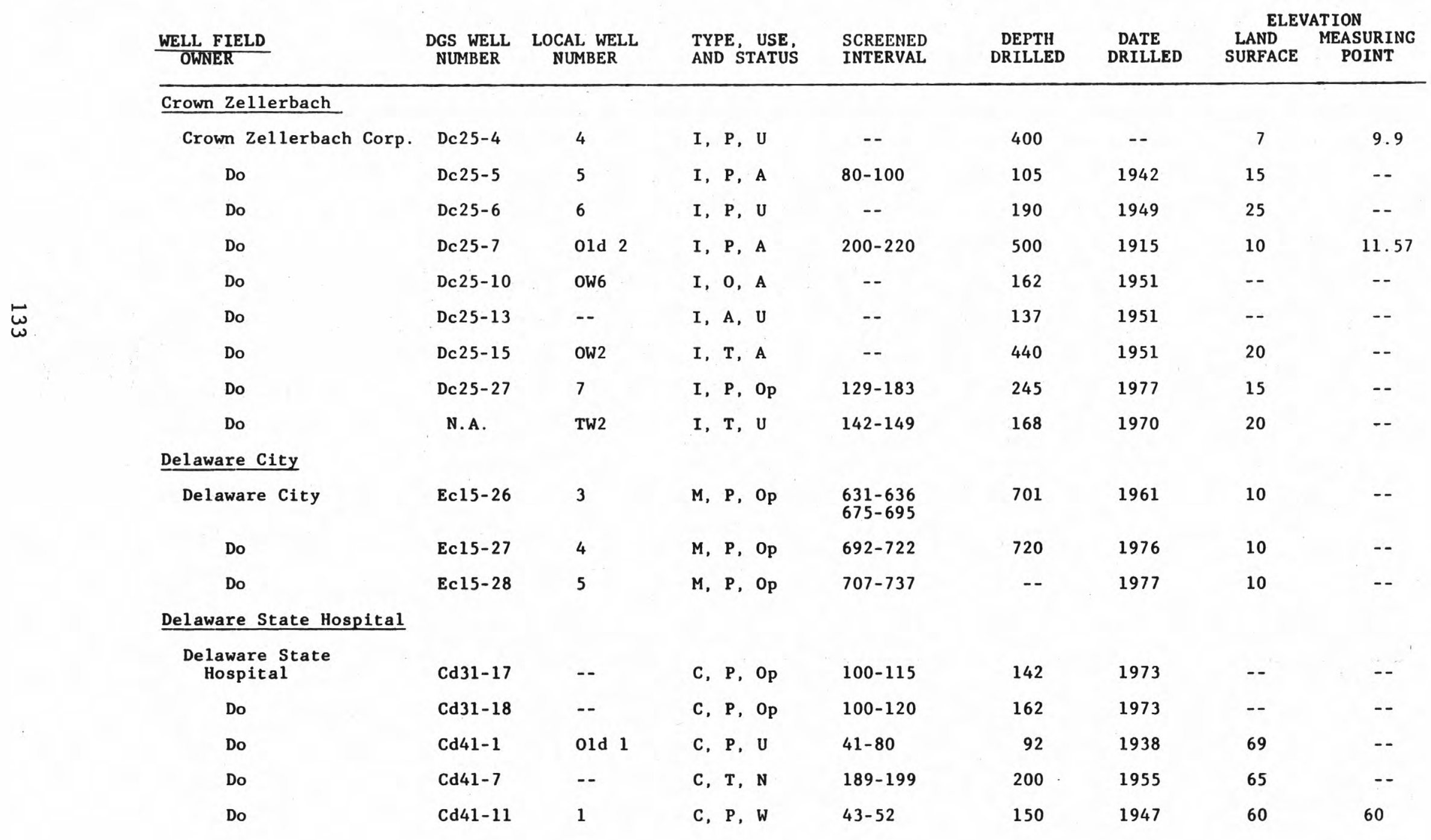


TABLE 7.--Partial record of wells in the Potomac Formation in New Castle County--Continued

\begin{tabular}{|c|c|c|c|c|c|c|c|c|}
\hline \multirow[b]{2}{*}{$\frac{\text { WELL FIELD }}{\text { OWNER }}$} & \multirow[b]{2}{*}{$\begin{array}{l}\text { DGS WELL } \\
\text { NUMBER }\end{array}$} & \multirow[b]{2}{*}{$\begin{array}{l}\text { LOCAL WELL } \\
\text { NUMBER }\end{array}$} & \multirow[b]{2}{*}{$\begin{array}{l}\text { TYPE, USE, } \\
\text { AND STATUS }\end{array}$} & \multirow[b]{2}{*}{$\begin{array}{l}\text { SCREENED } \\
\text { INTERVAL }\end{array}$} & \multirow[b]{2}{*}{$\begin{array}{l}\text { DEPTH } \\
\text { DRILLED }\end{array}$} & \multirow[b]{2}{*}{$\begin{array}{l}\text { DATE } \\
\text { DRILLED }\end{array}$} & \multicolumn{2}{|c|}{ ELEVATION } \\
\hline & & & & & & & $\begin{array}{l}\text { LAND } \\
\text { SURFACE }\end{array}$ & $\begin{array}{l}\text { MEASURING } \\
\text { POINT }\end{array}$ \\
\hline \multicolumn{9}{|c|}{ Delaware State Hospital } \\
\hline $\begin{array}{c}\text { Delaware State } \\
\text { Hospital }\end{array}$ & Cd41-18 & -- & $C, P, U$ & -- & 80 & 1961 & 69 & -- \\
\hline Do & Cd41-20 & -- & $\mathrm{C}, \mathrm{U}, \mathrm{U}$ & $60-80$ & 82 & 1970 & 69 & -- \\
\hline
\end{tabular}

Delmarva Power - Summit

Delmarva Power \& Light Co.

$\begin{array}{llll}\text { Eb44-9 } & \text { TW1 } & \text { I, T, N } & 325-375 \\ \text { Eb44-10 } & 603 & \text { I, T, U } & 355-370 \\ \text { Eb45-9 } & 801 & \text { I, O, W } & 344-384 \\ \text { Eb45-10 } & 802 & \text { I, O, W } & 330-380\end{array}$

40

$\begin{array}{lcll}403 & 1975 & 80 & 81 \\ -- & -- & 79.3 & 81.06 \\ 403 & 1975 & 80 & 81 \\ 403 & 1975 & 80 & 81\end{array}$

du Pont - Newport

\section{E. I. du Pont de Nemours}

Do
Do
Do
Do
Do
Do
Do

$\begin{array}{lllc}\text { Cc34-14 } & 11 & \text { I, P, Op } & -- \\ \mathrm{Cc} 34-15 & 13 & \text { I, P, OP } & 88.5-99 \\ \mathrm{Cc} 34-19 & 12 & \text { I, P, N } & 87-100 \\ \mathrm{Cc} 34-34 & \text { DM5 } & \text { I, O, W } & 53-63 \\ \mathrm{Cc} 34-36 & \text { DM1 } & \text { I, O, W } & 27-31 \\ \mathrm{Cc} 34-37 & \text { DM3 } & \text { I, O, W } & 53-62 \\ \mathrm{Cc} 34-38 & \text { DM4 } & \text { I, O, W } & -- \\ \mathrm{Cc} 34-39 & \text { DM6 } & \text { I, O, W } & 60-70\end{array}$

Fairwinds

Artesian Water Co.

Dc22-12

D- 6

S, $0, \mathrm{w}$

232-240

$254-264$
$278-283$

Do

Dc22-13 7

S, P, Op

81-113

$\begin{array}{rrrr}65 & 1930 & 22.0 & -- \\ 112 & 1953 & 34.0 & -- \\ 116 & 1930 & 25 & -- \\ 81 & 1977 & 7.5 & -- \\ 56 & 1975 & 16.2 & -- \\ 63 & 1976 & 23.6 & -- \\ 51 & 1976 & 7.5 & -- \\ 70 & 1977 & 1.9 & --\end{array}$

509

1973

51

117

1974

$-$ 
TABLE 7.--Partial record of wells in the Potomac Formation in New Castle County--Continued

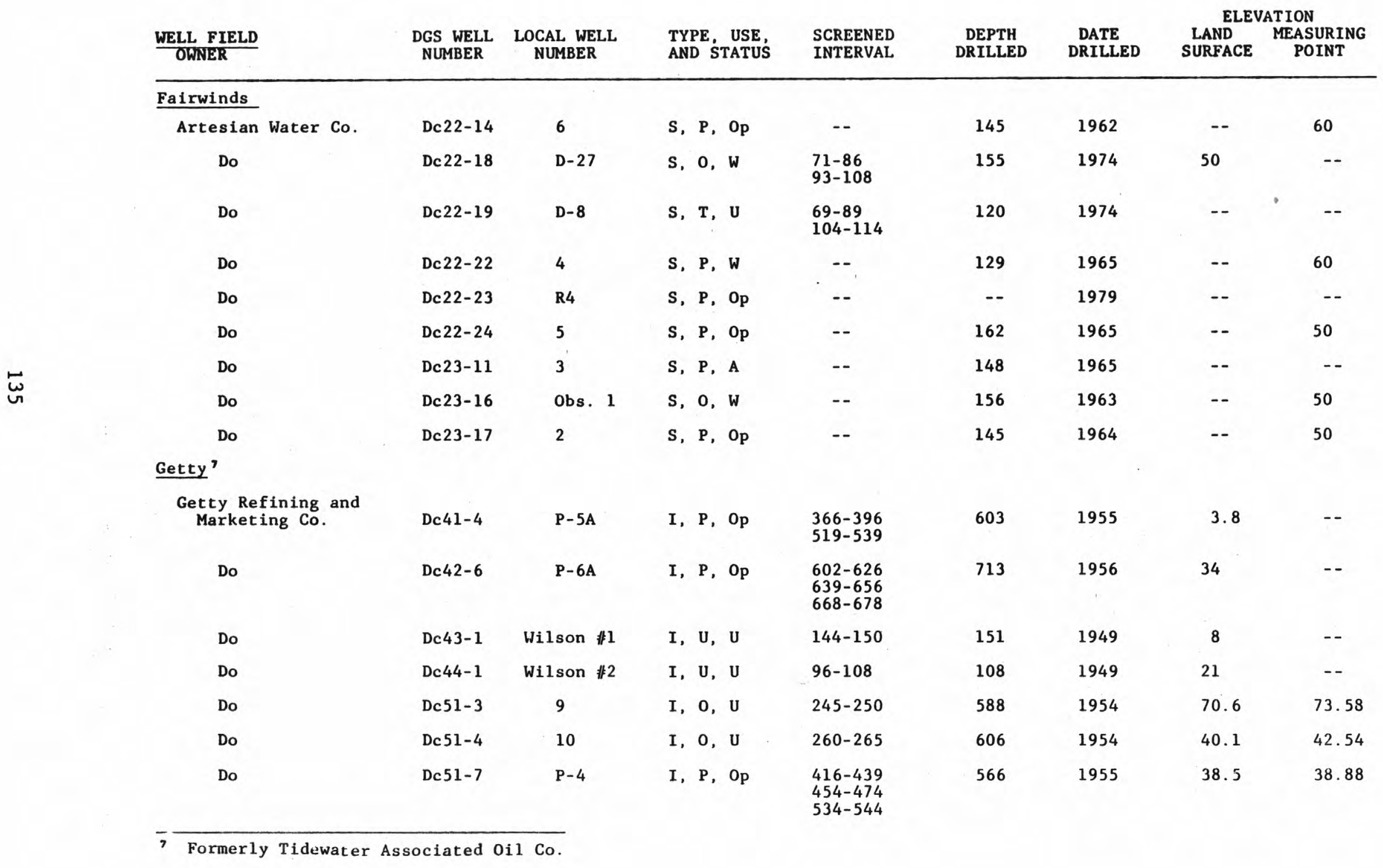


IADLE ,.--rarclal recora or wels in the Potomac Formation in New Castle County--Continued

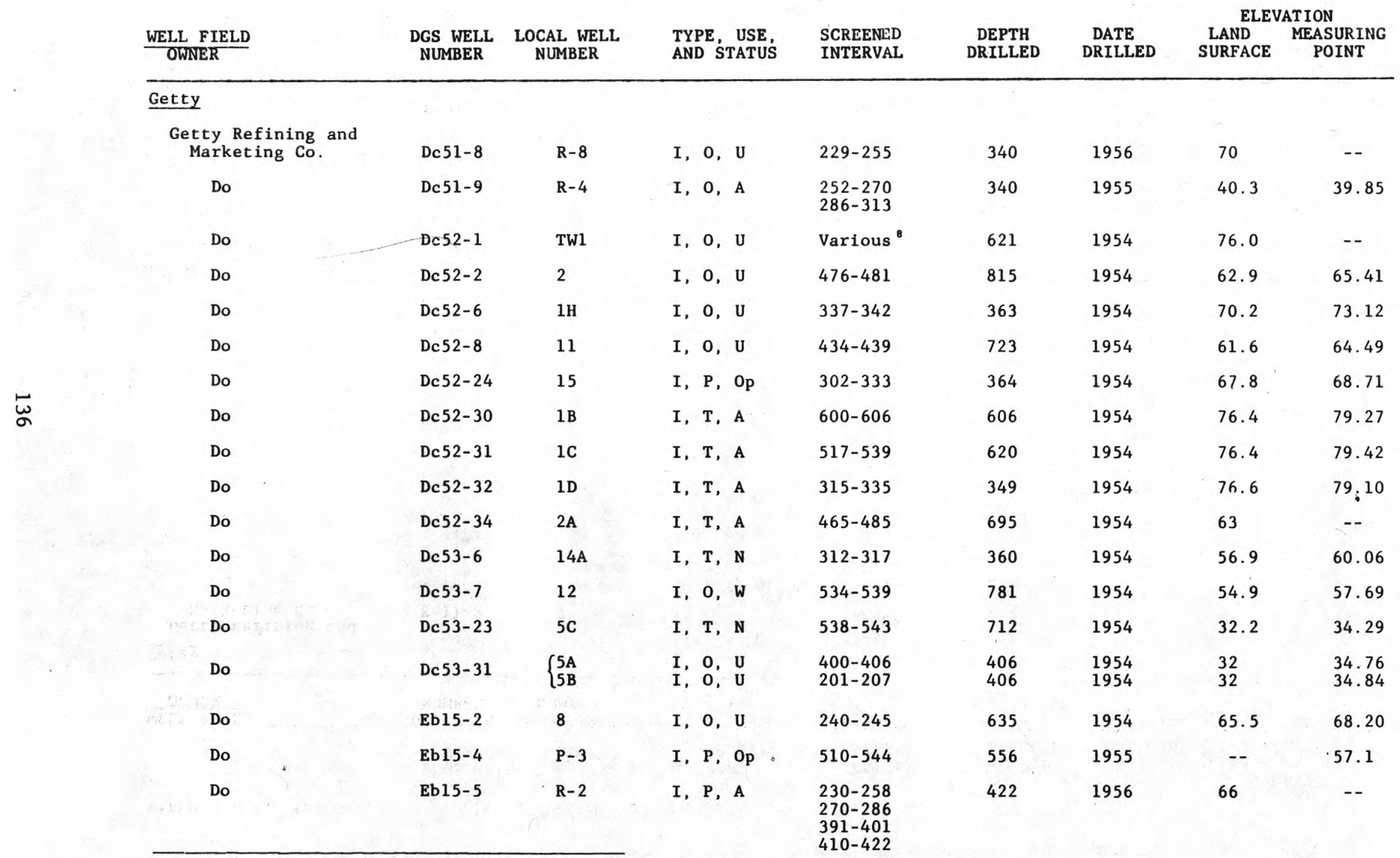

Screen interval varied from $320-340$ to $520-540$ for water quality sampling.
Present screen interval unknown. 
TABLE 7.--Partial record of wells in the Potomac Formation in New Castle County--Continued

\begin{tabular}{|c|c|c|c|c|c|c|c|c|c|}
\hline & \multirow[b]{2}{*}{$\frac{\text { WELL FIELD }}{\text { OWNER }}$} & \multirow[b]{2}{*}{$\begin{array}{l}\text { DGS WELL } \\
\text { NUMBER }\end{array}$} & \multirow[b]{2}{*}{$\begin{array}{l}\text { LOCAL WELL } \\
\text { NUMBER }\end{array}$} & \multirow[b]{2}{*}{$\begin{array}{l}\text { TYPE, USE, } \\
\text { AND STATUS }\end{array}$} & \multirow[b]{2}{*}{$\begin{array}{l}\text { SCREENED } \\
\text { INTERVAL }\end{array}$} & \multirow[b]{2}{*}{$\begin{array}{l}\text { DEPTH } \\
\text { DRILLED }\end{array}$} & \multirow[b]{2}{*}{$\begin{array}{l}\text { DATE } \\
\text { DRILLED }\end{array}$} & \multicolumn{2}{|c|}{ ELEVATION } \\
\hline & & & & & & & & $\begin{array}{l}\text { LAND } \\
\text { SURFACE }\end{array}$ & $\begin{array}{l}\text { MEASURING } \\
\text { POINT }\end{array}$ \\
\hline & \multicolumn{9}{|l|}{ Getty } \\
\hline \multirow{22}{*}{$\underset{w}{\omega}$} & $\begin{array}{l}\text { Getty Refining and } \\
\text { Marketing Co. }\end{array}$ & Ecll-2 & 7 & $\mathrm{I}, 0, \mathrm{U}$ & $560-565$ & 758 & 1954 & 41.5 & 44.07 \\
\hline & Do & Ec12-2 & 3 & $\mathrm{I}, 0, \mathrm{~W}$ & $549-553$ & 605 & 1954 & 57.1 & 60.40 \\
\hline & Do & Ec12-3 & $P-6$ & $\mathrm{I}, 0, \mathrm{U}$ & $548-553$ & 828 & 1954 & 13.1 & 15.65 \\
\hline & Do & Ec12-15 & $3 B$ & $\mathrm{I}, 0, \mathrm{U}$ & $340-345$ & 734 & 1954 & 57.5 & 60.20 \\
\hline & Do & Ec12-20 & $P-9$ & $I, P, O p$ & $525-558$ & 574 & 1956 & 13 & $14: 34$ \\
\hline & Do & Ec13-5 & 4 & $\mathrm{I}, 0, \mathrm{U}$ & $543-547$ & 694 & 1954 & 59.1 & 62.21 \\
\hline & Do & Ec13-6 & 16 & $I, P, O p$ & $\begin{array}{l}523-563 \\
581-592\end{array}$ & 705 & 1955 & 35.5 & 36.26 \\
\hline & Do & Ec14-1 & 13 & $\mathrm{I}, 0, \mathrm{U}$ & $678-685$ & 751 & 1954 & 4.4 & 6.64 \\
\hline & Do & Ec14-7 & $P-10$ & $I, P, O p$ & $\begin{array}{l}642-668 \\
692-702\end{array}$ & 764 & 1956 & 9 & -- \\
\hline & Do & Ec22-3 & $P-1$ & $I, P, O p$ & $235-260$ & 261 & 1952 & 10 & -- \\
\hline & \multicolumn{9}{|l|}{ Glendale and lloores Farm } \\
\hline & Artesian Water Co. & $\mathrm{Db} 35-3$ & -- & $\mathrm{S}, \mathrm{P}, \mathrm{N}$ & $77-87$ & 120 & 1956 & 80 & -- \\
\hline & Do & Db35-4 & -- & $\mathrm{S}, \mathrm{P}, \mathrm{N}$ & $88-100$ & 100 & 1953 & 80 & -- \\
\hline & Do . & $\mathrm{Db} 35-6$ & -- & $S, P, N$ & $92-102$ & 107 & 1957 & 70 & -- \\
\hline & Do & Dc21-10 & $\begin{array}{l}\text { Site } 6^{-} \\
\text {Moores Farm }\end{array}$ & $\mathrm{S}, \mathrm{T}, \mathrm{U}$ & $115-139$ & 154 & 1975 & -- & -- \\
\hline & Do & De $31-10$ & 5 & $S, P, O p$ & $108-138$ & 138.5 & 1973 & 69 & -- \\
\hline & Do & Dc31-12 & TW 1 & $\mathrm{~S}, 0, \mathrm{U}$ & $460-510$ & 549 & 1973 & -- & -- \\
\hline & Do & Dc 31-13 & $5 A$ & $\mathrm{~S}, 0, \mathrm{~W}$ & -- & -- & -- & 69 & -- \\
\hline & Do & Dc31-18 & $\begin{array}{l}\text { 1, Site } 4- \\
\text { Moores Farm }\end{array}$ & $\mathrm{S}, \mathrm{T}, \mathrm{W}$ & $125-155$ & 163 & 1975 & 71 & -- \\
\hline & Do & Dc31-21 & 6 & $S, P, O p$ & $115-138$ & 138 & 1974 & 65 & -- \\
\hline & Do & Dc 31-24 & 7-Moores Farm & $S, P, O p$ & $123-153$ & 156 & 1976 & -- & -- \\
\hline & Do & Dc $31-25$ & D-2 & $\mathrm{S}, 0, \mathrm{U}$ & $125-135$ & 147 & 1973 & -- & -- \\
\hline
\end{tabular}


TABLE 7.--Partial record of vells in the Potomac Formation in New Castle County--Continued

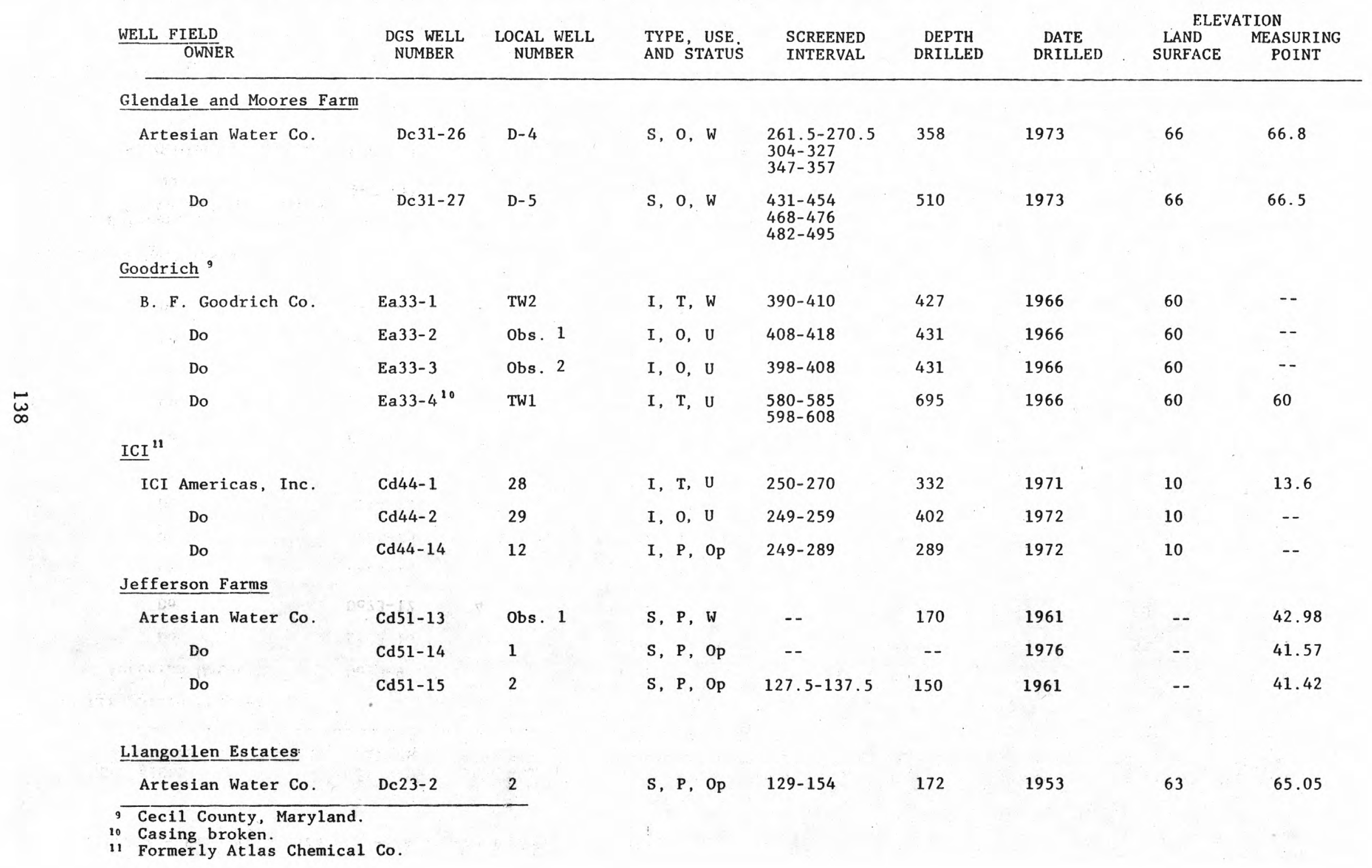


TABLE 7.--Partial record of wells in the Potomac Formation in New Castle County--Lontinueu

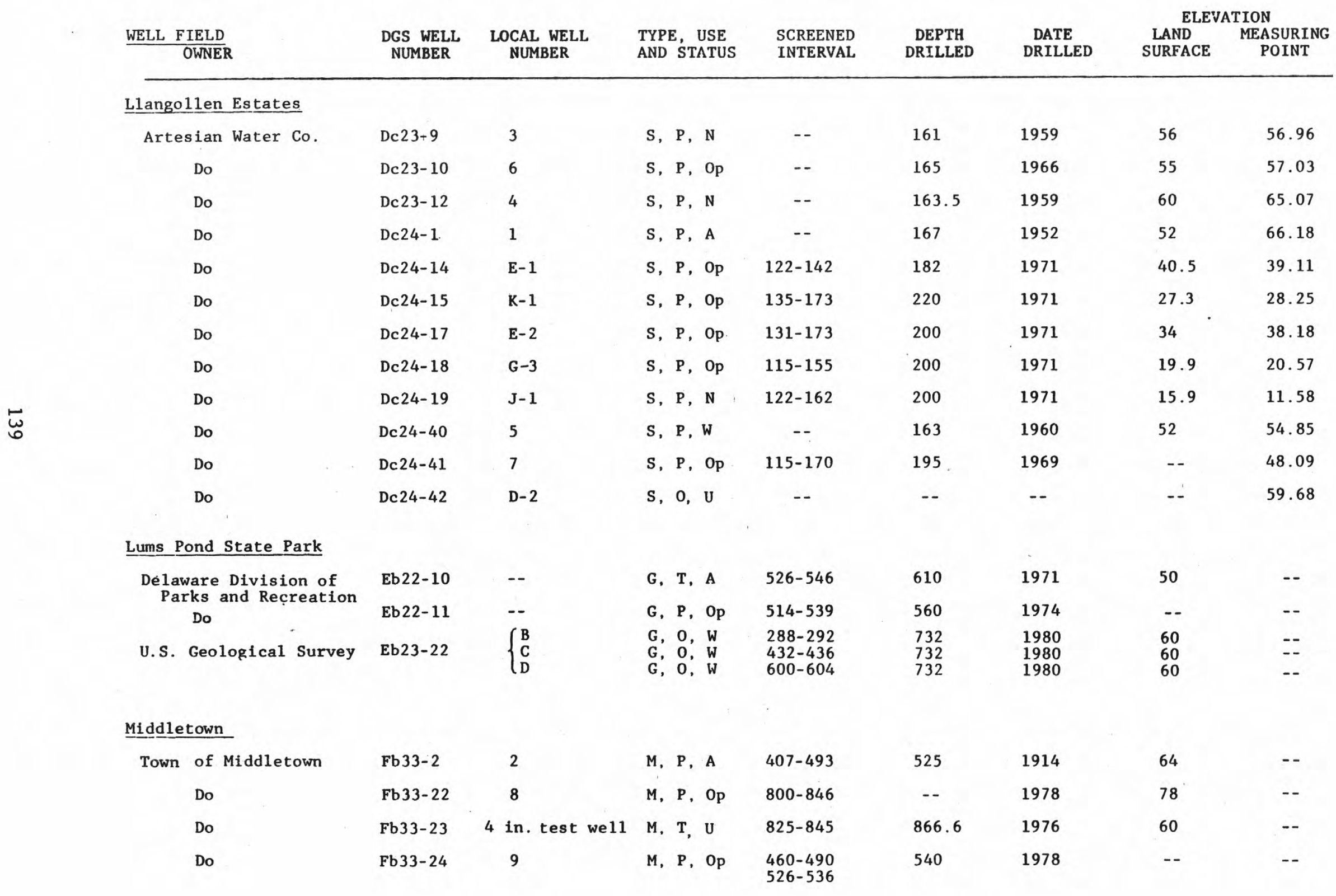


TABLE 7.--Partial record of wells in the Potomac Formation in New Castle County--Continued

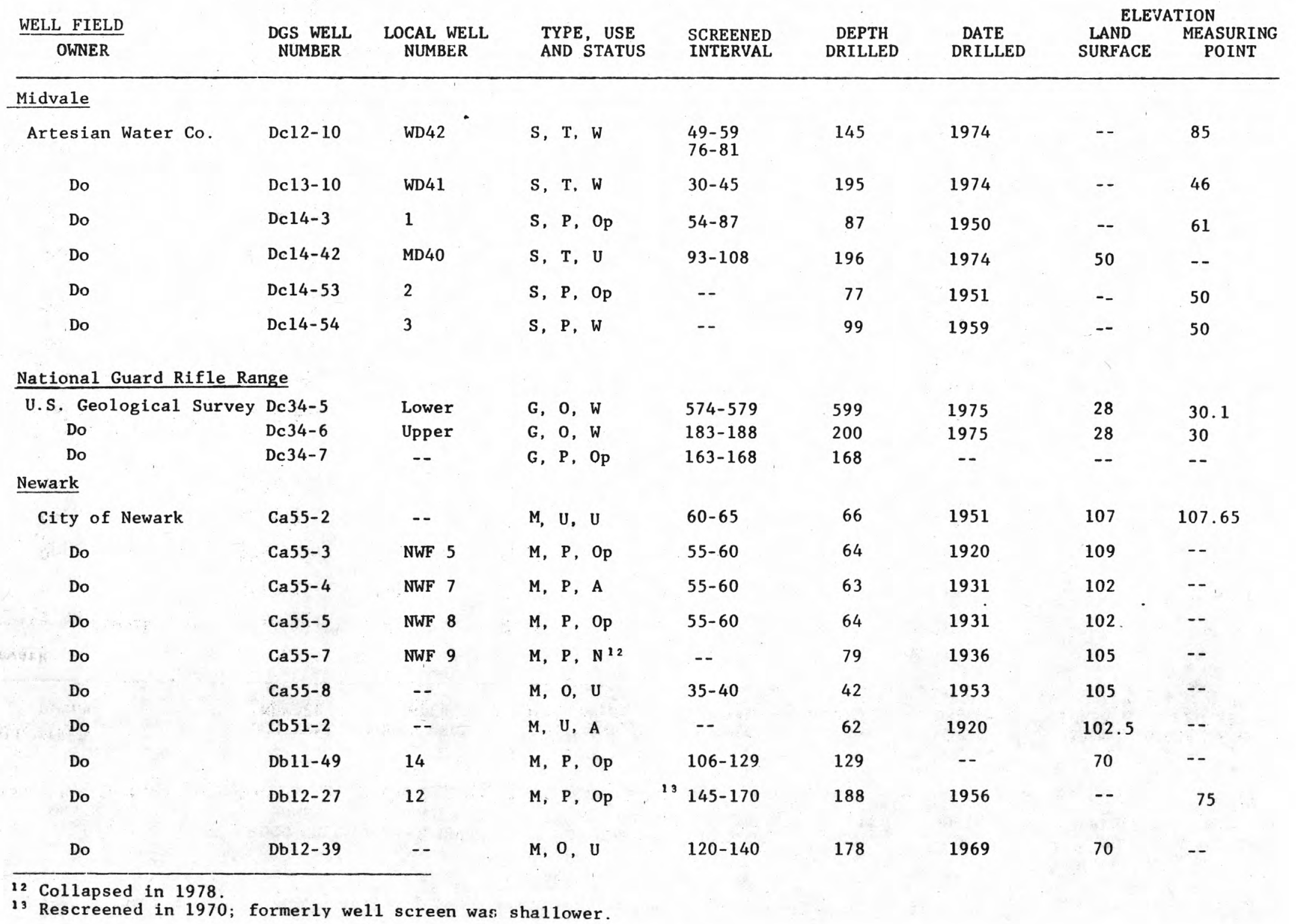


TABLE 7.--Partial record of wells in the Potomac Formation in New Castle County--Continued

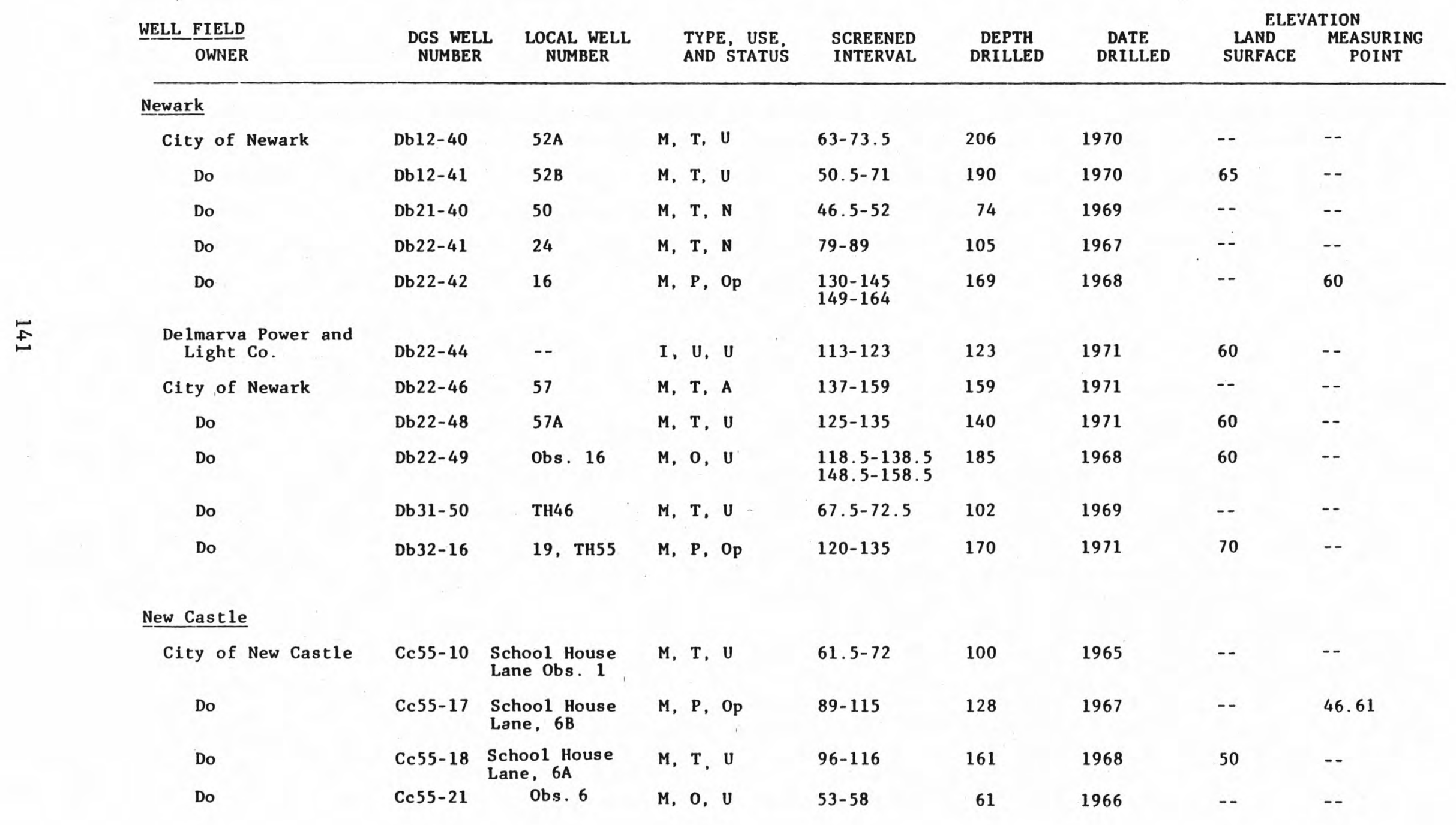


TABLE 7.--Partial record of wells in the Potomac Formation in New Castle County--Continued

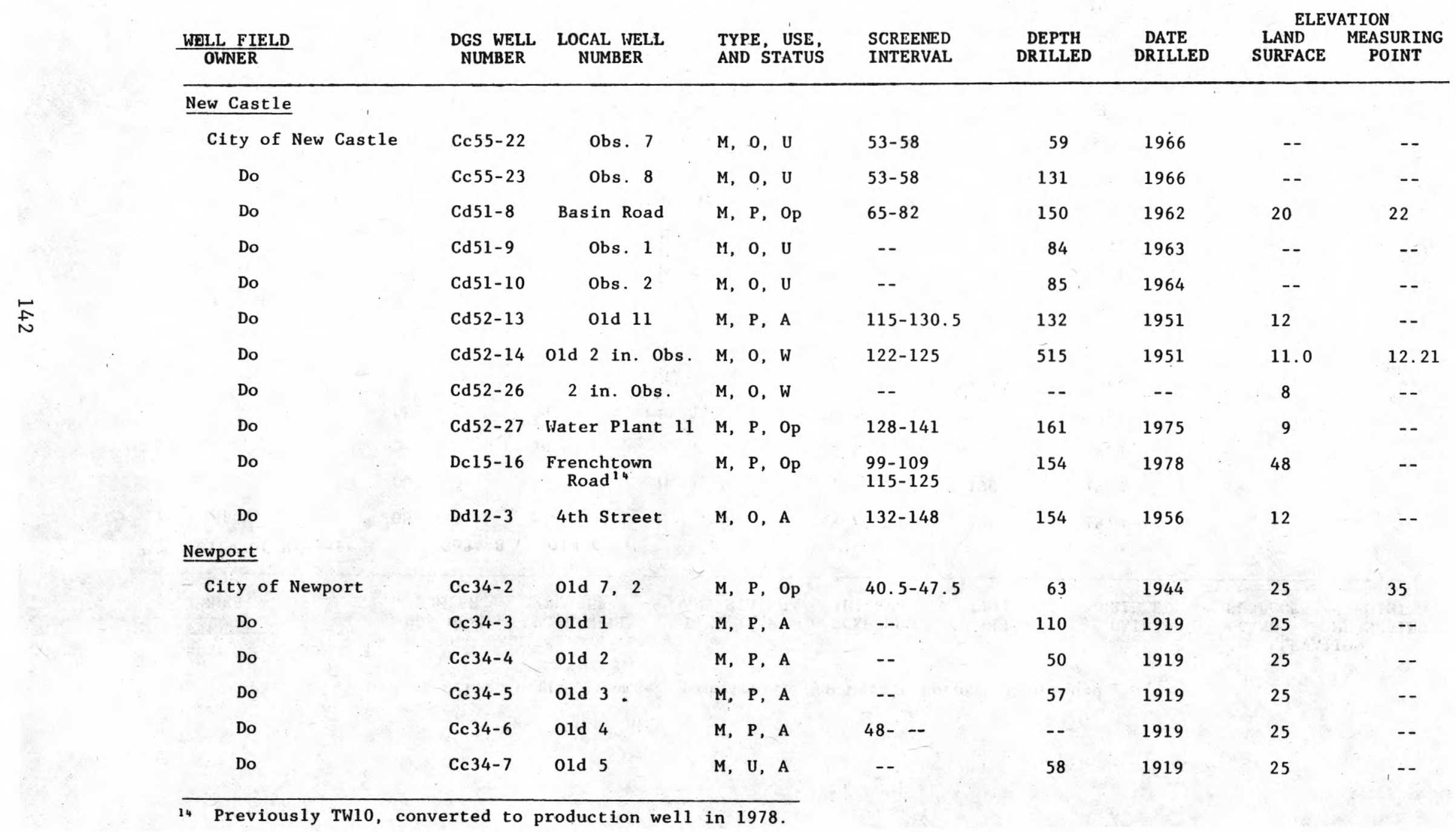


TABLE 7.--Partial record of wells in the Potomac Formation in New Castle County--Continued

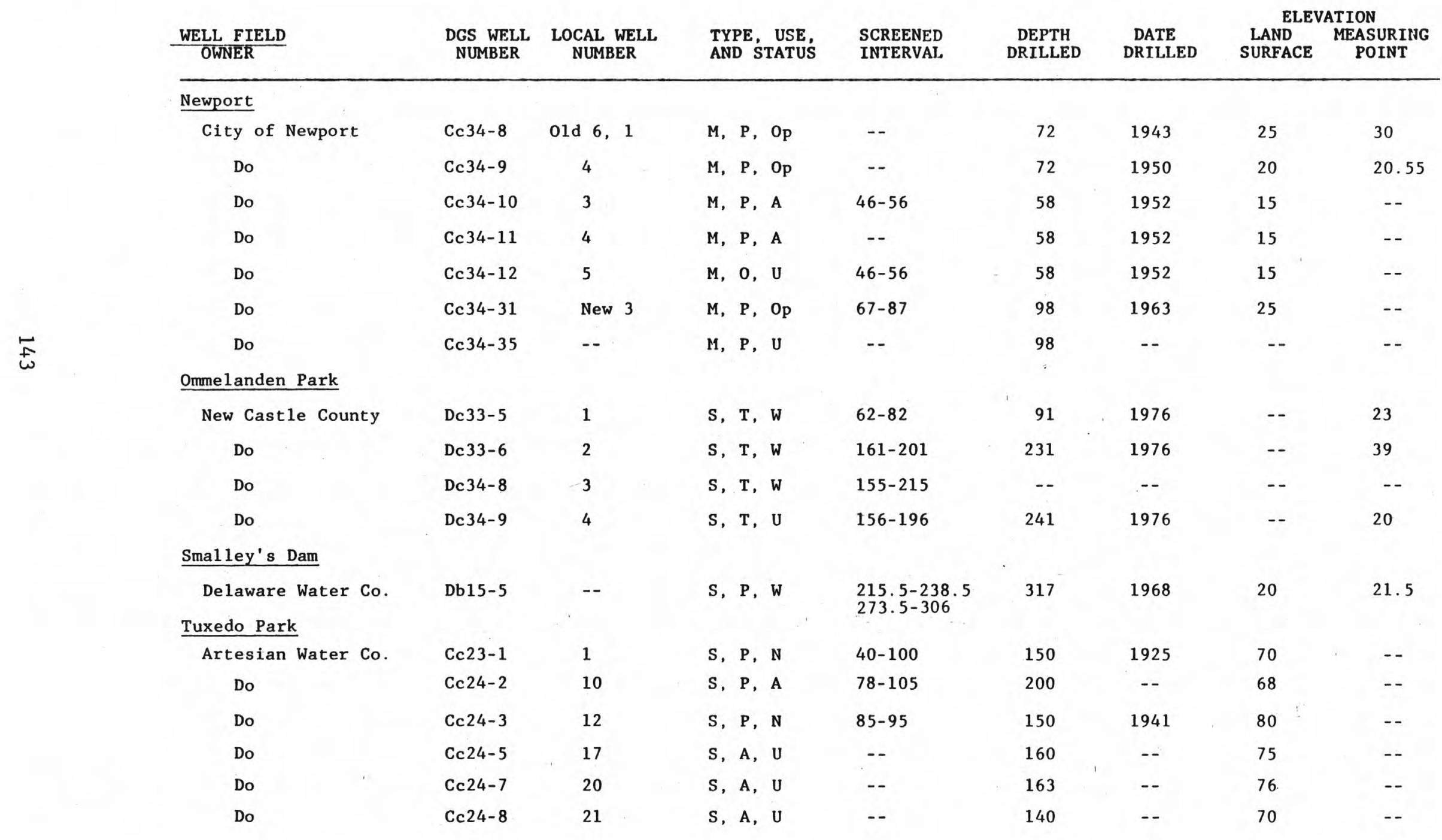


TABLE 7.--Partial record of wells in the Potomac Formation in New Castle County--Continued

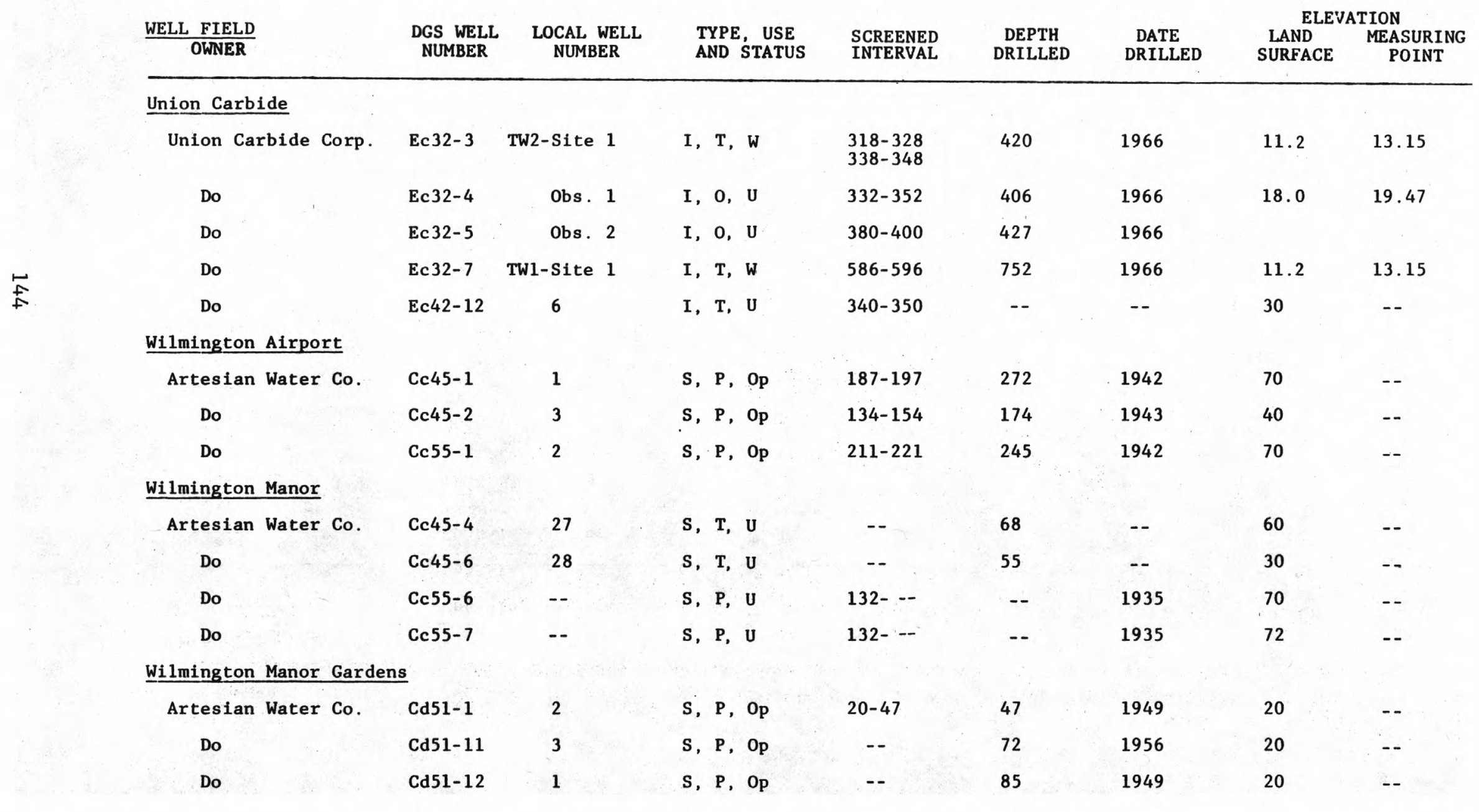


TABLE 7.--Partial record of wells in the Potomac Formation in New Castle County--Continued

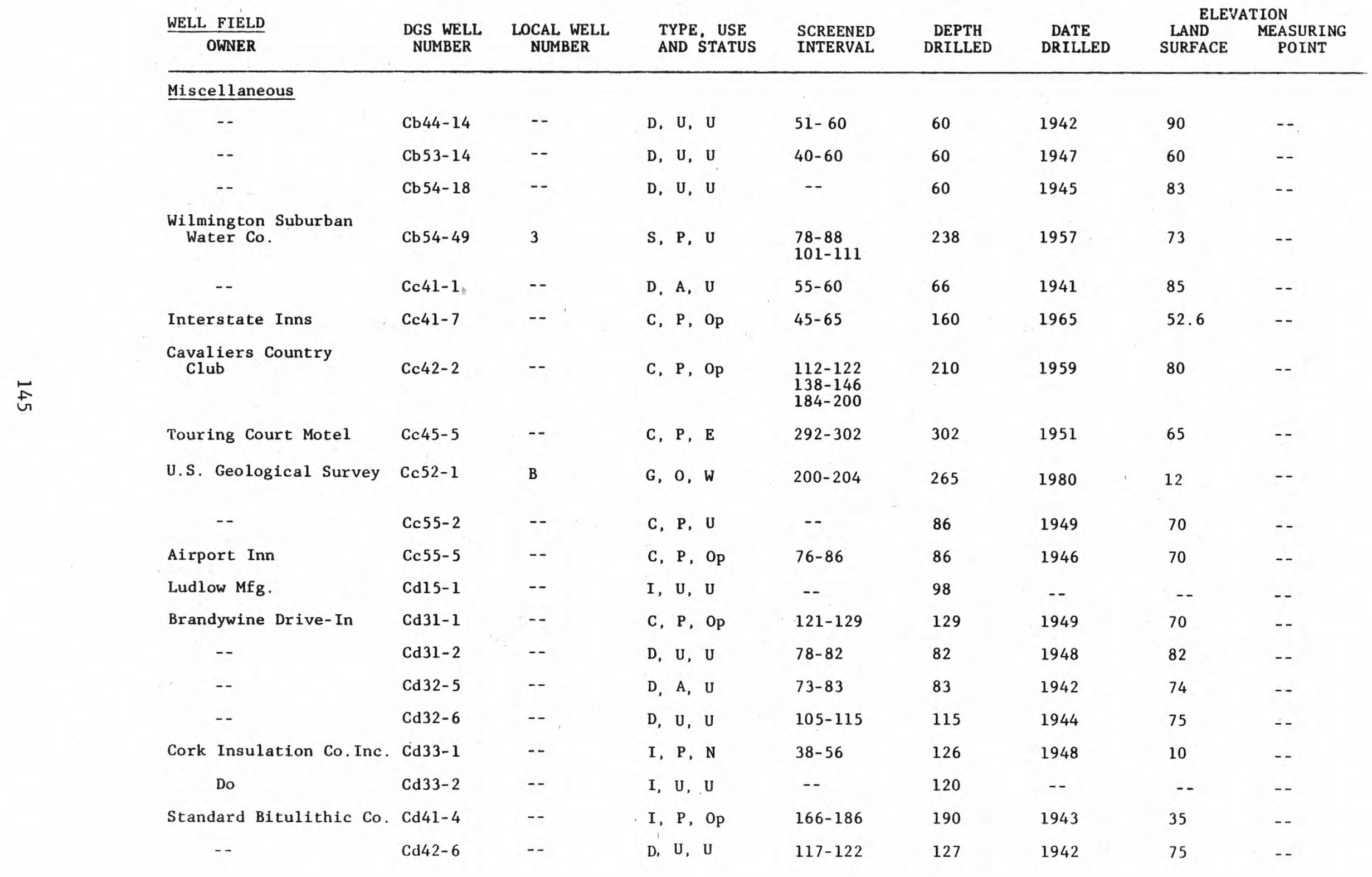


TABLE 7.--Partial record of wells in the Potomac Formation in New Castle County--Continued

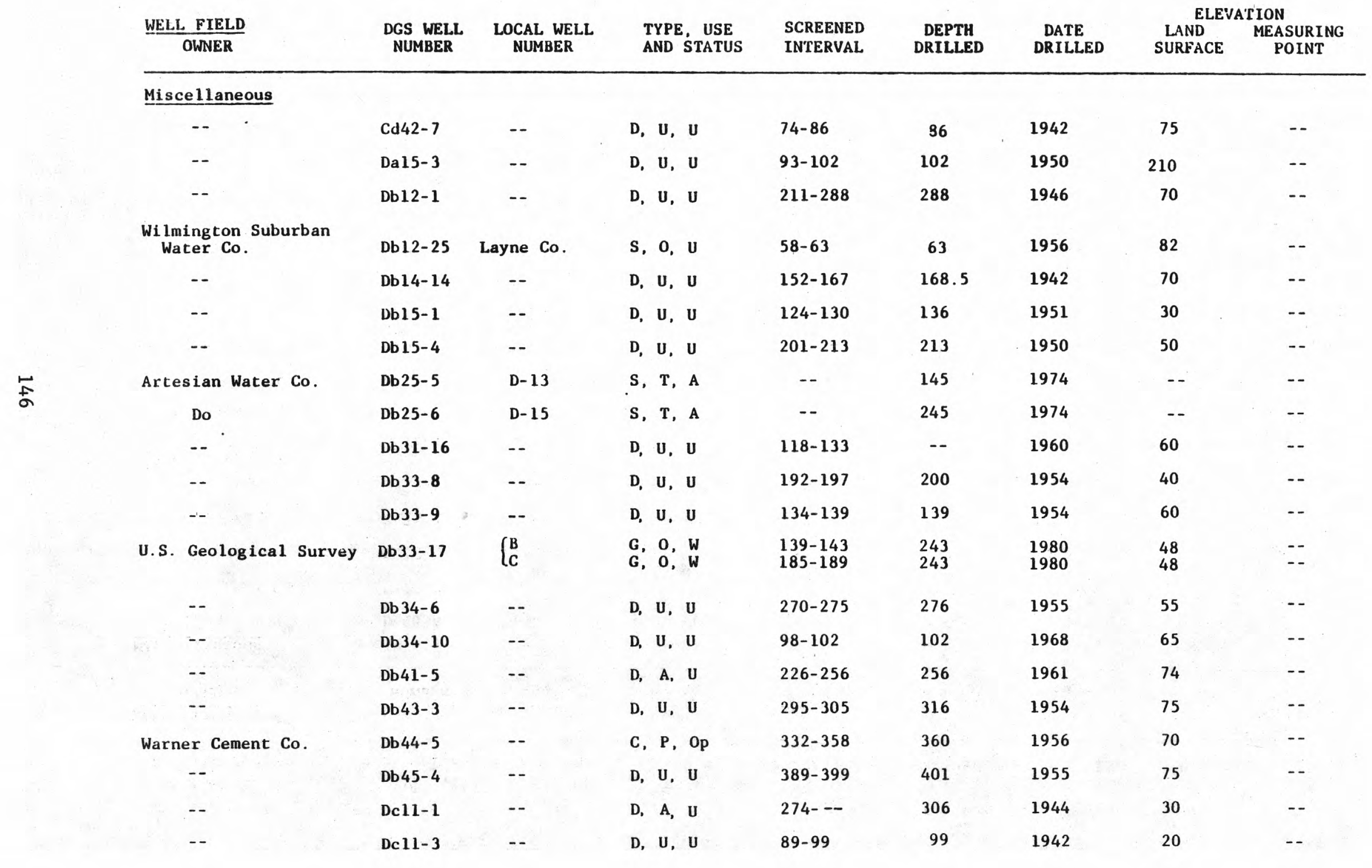


TABLE 7.--Partial record of wells in the Potomac Formation in New Castle County--Continued

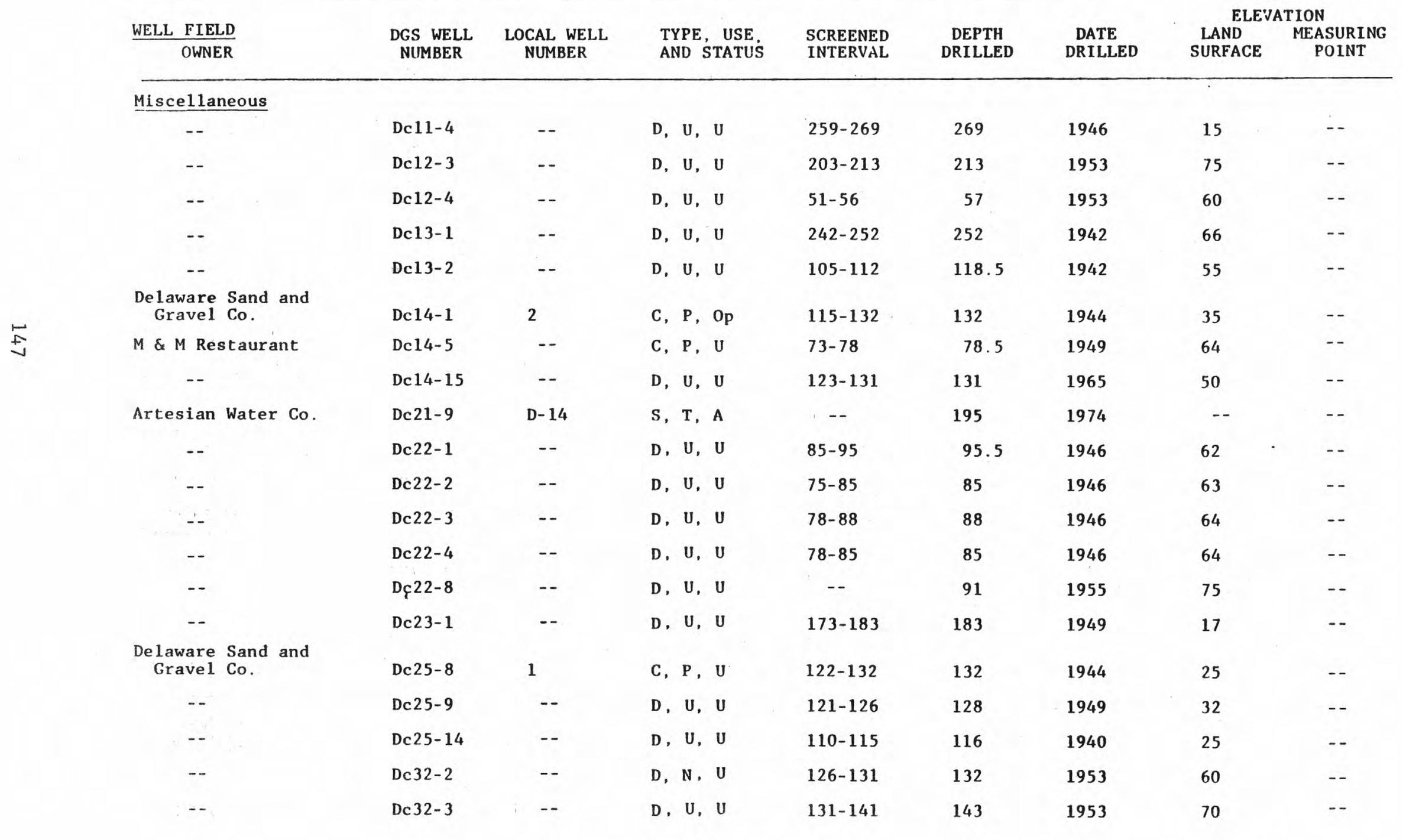




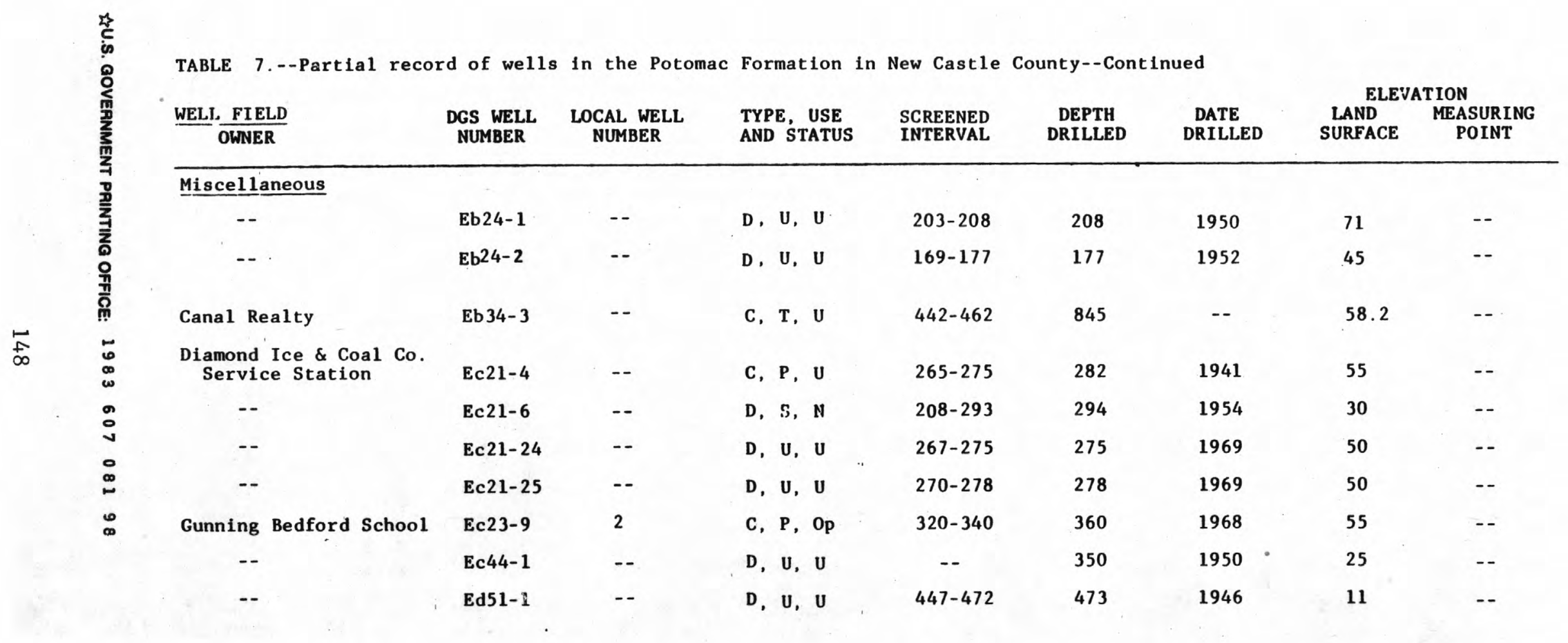




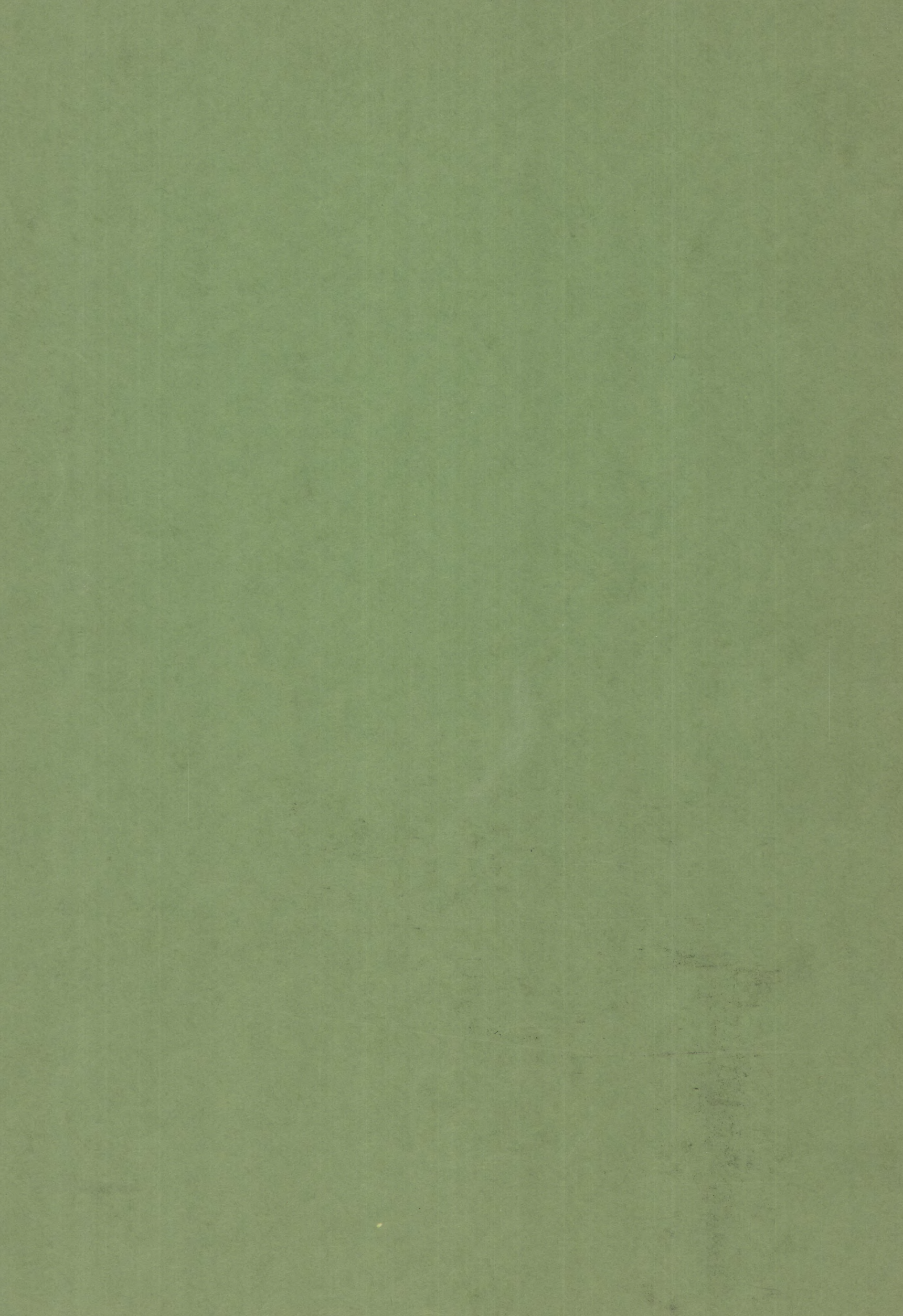

